The Texas Medical Center Library

DigitalCommons@TMC

8-2014

\title{
ASSOCIATION OF CARDIORESPIRATORY FITNESS AND ADIPOSITY WITH INFLAMMATORY BIOMARKERS IN YOUNG ADULTS
}

Eunduck Park

University of Texas Health Science Center at Houston School of Nursing

Follow this and additional works at: https://digitalcommons.library.tmc.edu/uthson_etd

Part of the Nursing Commons

\footnotetext{
Recommended Citation

Park, Eunduck, "ASSOCIATION OF CARDIORESPIRATORY FITNESS AND ADIPOSITY WITH

INFLAMMATORY BIOMARKERS IN YOUNG ADULTS" (2014). UT SON Dissertations (Open Access). 5.

https://digitalcommons.library.tmc.edu/uthson_etd/5
}

This is brought to you for free and open access by the School of Nursing at DigitalCommons@TMC. It has been accepted for inclusion in UT SON Dissertations (Open Access) by an authorized administrator of DigitalCommons@TMC. For more information, please contact digitalcommons@library.tmc.edu.

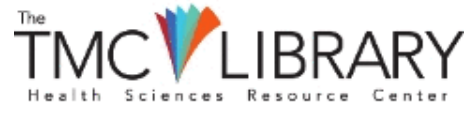


ASSOCIATION OF CARDIORESPIRATORY FITNESS AND ADIPOSITY WITH INFLAMMATORY BIOMARKERS IN YOUNG ADULTS

\author{
A DISSERTATION \\ SUBMITTED IN PARTIAL FULFILLMENT OF THE REQUIREMENTS \\ FOR THE DEGREE OF DOCTOR OF PHILOSOPHY IN NURSING
}

THE UNIVERSITY OF TEXAS HEALTH SCIENCE CENTER AT HOUSTON

SCHOOL OF NURSING

BY

EUNDUCK PARK, MSN, RN

AUGUST, 2014 
The University of Texas Health Science Center at Houston School of Nursing Houston, Texas

May 27, 2014

Date

To the Dean for the School of Nursing:

I am submitting a dissertation written by Eunduck Park and entitled "Association of Cardiorespiratory Fitness and Adiposity with Inflammatory Biomarkers in Young Adults." I have examined the final copy of this dissertation for form and content and recommend that it be accepted in partial fulfillment of the requirements for the degree of Doctor of Philosophy in Nursing.

We have read this dissertation

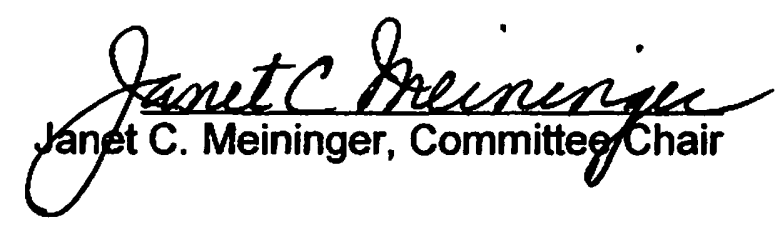
and recommend its acceptance:
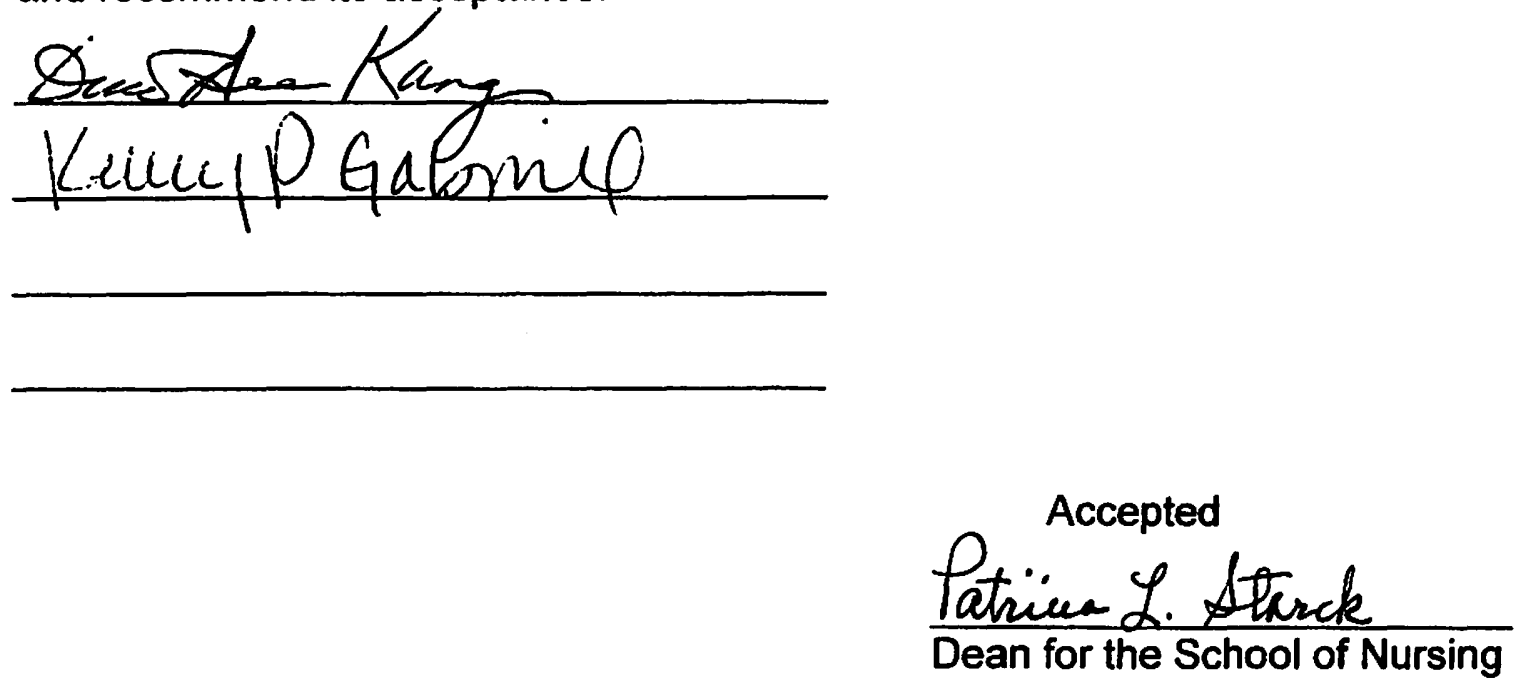


\section{Acknowledgements}

It was an invaluable $\mathrm{PhD}$ journey in my life. I am grateful to all of the people who have supported me along the way. I would never be able to complete my dissertation without all their supports.

First of all, I would like to express my deepest appreciation to my advisor and committee chair Dr. Meininger for her excellent guidance, strong support and outstanding mentorship throughout my entire $\mathrm{PhD}$ program. I also express my sincere gratitude to my distinguished dissertation committee members, Dr. Kang, who let me experience in field of biobehaviroal research and biomarkers and Dr. Gabriel for her expertise in cardiorespiratory fitness. Thank you to Dr. Padhye for his expertise in statistical supports and Dr. Baun for candidacy committee.

I also give my thanks to Dr. Bergstrom and staff in Center for Nursing Research, and biolaboratory for supporting this dissertation. I gratefully appreciate 88 young adult volunteer participants. I also want to give my sincere gratitude and appreciation to the PARTNERS scholarship and the Willerson Endowment scholarship for my PhD program. Without all generous supports, I would not complete my $\mathrm{PhD}$ program and dissertation. Thank you.

Lastly, I would like to thank my husband Hyunyul Choi for his devoted love and encouragement during the $\mathrm{PhD}$ program. I greatly thank my parents Sang-Geun Park, Young-Ae Kim, and parents-in law Sang-Gon Choi, Chil-Soo Park for their unconditional love, incredible supports and praying for me everyday.

This dissertation was funded by Sigma Theta Tau International Zeta Pi and Global Korean Nursing Foundation Scholarship in USA. This dissertation also supported by 
Center for Nursing Research for a treadmill and Dr. Meininger's professorship research support. 
Association of Cardiorespiratory Fitness and Adiposity with Inflammatory

Biomarkers in Young Adults

August, 2014

\begin{abstract}

\section{Background}

Low grade systemic inflammation plays a key role in atherosclerosis, and C-reactive protein (hs-CRP), interleukin-6 (IL-6), and tumor necrosis factor- alpha (TNF- $\alpha$ ), markers of systemic inflammation, are associated with cardiovascular events and adiposity. Cardiorespiratory fitness has shown health benefits by reducing circulating levels of inflammatory markers. However, it remains uncertain whether the negative association between cardiorespiratory fitness and inflammatory biomarkers is due to cardiorespiratory fitness itself or results from lower levels of adiposity. Moreover, the evidence examining the interaction between cardiorespiratory fitness and adiposity in inflammation in young adults is lacking.
\end{abstract}

\title{
Purpose
}

The aims of this study were to (1) determine the strength of the associations of cardiorespiratory fitness and adiposity (body mass index [BMI], waist circumference [WC]) with circulating levels of plasma hs-CRP, IL-6, and TNF- $\alpha$; and (2) test the moderating effect of adiposity on the strength of the association between cardiorespiratory fitness and circulating levels of plasma hs-CRP, IL-6, and TNF- $\alpha$. Methods

A cross-sectional study was conducted with 88 young adults aged 20-34 years without diagnosed diseases. A submaximal treadmill walking test was used to assess 
cardiorespiratory fitness. BMI and WC were measured to assess adiposity. The hs-CRP, IL- 6 and TNF- $\alpha$ were assayed and were $\log _{10}$-transformed. For aim one, a separate multiple regression analysis was conducted with each of hs-CRP, IL-6, and TNF- $\alpha$ as dependent variables and adjusted for confounders. Analysis of covariance (ANCOVA) was used and adjusted for confounders for aim two. Confounding variables tested were sex, ethnicity, oral contraceptive use, and education level.

\section{Results}

Aim1: Cardiorespiratory fitness was not significantly associated with $\log _{10} \mathrm{hs}-\mathrm{CRP}$ after adjustment for BMI or WC and confounders. Cardiorespiratory fitness was not significantly associated with $\log _{10} \mathrm{IL}-6$ after adjustment for BMI and confounders. However, cardiorespiratory fitness was significantly and negatively associated with $\log _{10} \mathrm{IL}-6$ after adjustment for WC and confounders (Model adjusted $\mathrm{R}^{2}=.273, p<.0001$; $\beta=-.341, \mathrm{t}=-1.995, p=.049)$. Aim 2: Cardiorespiratory fitness $\times \mathrm{BMI}$ or WC interaction was not significantly associated with $\log _{10} \mathrm{hs}$-CRP after adjustment for confounders. Similarly, cardiorespiratory fitness $\times \mathrm{BMI}$ interaction was not significantly associated with $\log _{10} \mathrm{IL}-6$ after adjustment for confounders. However, cardiorespiratory fitness $\times$ WC interaction was significantly associated with $\log _{10} \mathrm{IL}-6$ after adjustment for confounders (Model adjusted $\mathrm{R}^{2}=.258, p<.0001 ;$ partial eta $^{2}=.056, \mathrm{~F}=4.730, p=$ .033 ). There were no associations of cardiorespiratory fitness, adiposity, and $\log _{10}$ TNF- $\alpha$.

\section{Conclusions}

In young adults, higher cardiorespiratory fitness is significantly associated with lower levels of IL-6, particularly in young adults with central adiposity. Further studies are warranted to determine if experimentally induced increases in cardiorespiratory fitness 
reduce inflammatory markers in young adults. Longitudinal studies are needed to understand the underlying inflammatory mechanisms related to interaction between cardiorespiratory fitness and adiposity, and its influence on cardiovascular disease risk in young adults. 


\section{TABLE OF CONTENTS}

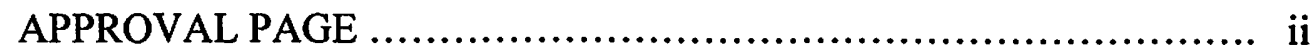

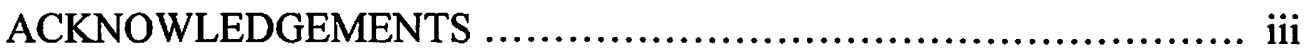

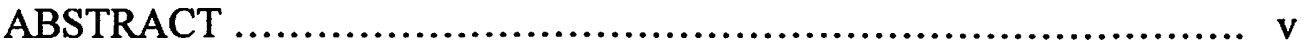

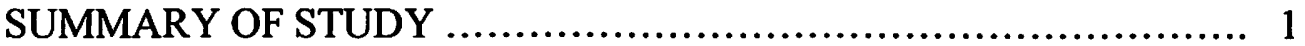

PROPOSAL ............................................................ 3

Specific Aims ..................................................... 6

Research Strategy ...................................................... 8

Human Subject ....................................................... 26

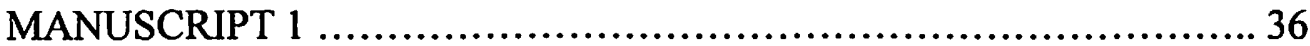

Park, E., Meininger, J. C., Baun, M., \& Kang, D.. Anthropometric adiposity measures and inflammatory biomarkers in adolescents and young adults: A systematic review.

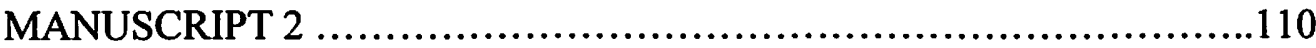

Park, E., Meininger, J. C., Kang, D., \& Gabriel, K. P.. Association of Cardiorespiratory fitness and adiposity with inflammatory biomarkers in young adults.

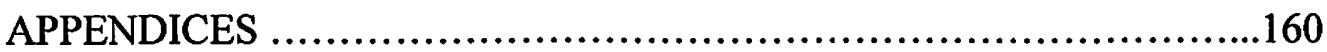

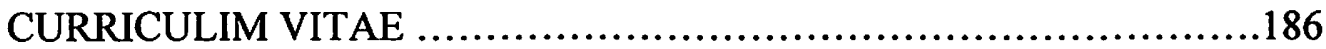




\section{Summary of Study}

The dissertation consists of the proposal, two manuscripts reporting study results, and appendixes. The proposal consists of specific aims, research strategy, facilities/ resources/ consultants, and human subject concerns. Two manuscripts are included: manuscript 1. Anthropometric Adiposity Measures and Inflammatory Biomarkers in Adolescents and Young Adults: A Systematic Review and manuscript 2. Association of Cardiorespiratory Fitness and Adiposity with Inflammatory Biomarkers in Young Adults: dissertation.

Manuscript 1 is the systematic review on the associations between anthropometric adiposity measures (BMI, WC, WHR, WHtR, and BF\%) and inflammatory biomarkers (CRP, IL-6, and TNF- $\alpha$ ) in adolescents and young adults. This review found that anthropometric adiposity measures are positively associated with CRP in adolescents and young adults. However, anthropometric adiposity measures and IL-6 and TNF- $\alpha$ in adolescents and young adults is inconclusive. Additional studies are needed to identify the strength and patterns of association of anthropometric adiposity measures with CRP, IL-6 and TNF- $\alpha$.

Manuscript 2 is a dissertation study. This cross-sectional study is to (1) determine the strength of the associations of cardiorespiratory fitness and adiposity (body mass index [BMI], waist circumference [WC]) with circulating levels of plasma hs-CRP, IL-6, and TNF- $\alpha$; and (2) test the moderating effect of adiposity on the strength of the association between cardiorespiratory fitness and circulating levels of plasma hs-CRP, IL-6, and TNF- $\alpha$. This study found that in young adults, higher cardiorespiratory fitness is significantly associated with lower levels of IL-6, particularly in young adults with 
central adiposity. Further studies are warranted to determine if experimentally induced increases in cardiorespiratory fitness reduce inflammatory markers in young adults.

Appendices include study protocols, IRB approval letters and human subject concerns. Curriculum vitae constitute the final section of the dissertation. 
ASSOCIATION OF CARDIORESPIRATORY FITNESS AND ADIPOSITY WITH INFLAMMATORY BIOMARKERS IN YOUNG ADULTS

\section{A DISSERTATION PROPOSAL}

SUBMITTED IN PARTIAL FULFILLMENT OF THE REQUIREMENTS FOR THE DEGREE OF DOCTOR OF PHILOSOPHY IN NURSING

THE UNIVERSITY OF TEXAS HEALTH SCIENCE CENTER AT HOUSTON SCHOOL OF NURSING

$$
\text { BY }
$$

EUNDUCK PARK, MSN, RN

July, 2012 


\begin{abstract}
Purpose: The proposed study is to investigate the association of cardiorespiratory fitness (CRF) and adiposity with inflammatory biomarkers in healthy young adults. Specific aims are (1) to determine the strength of the association between CRF levels with circulating levels of plasma high sensitivity C-reactive protein (hs-CRP), interleukin-6 (IL-6), and tumor necrosis factor- alpha (TNF- $\alpha$ ); (2) to determine the strength of the association between adiposity levels and circulating levels of plasma hs-CRP, IL-6, and TNF- $\alpha$; and (3) to test the moderating effect of adiposity on the strength of the association between CRF levels and circulating levels of plasma hs-CRP, IL-6, and TNF$\alpha$.
\end{abstract} Significance: Atherosclerotic cardiovascular disease is a significant public health concern. Low grade chronic vascular inflammation plays a key role in atherosclerosis. CRF has shown health benefits by reducing circulating levels of inflammatory markers. However, it is uncertain whether the beneficial effect of CRF derives from the CRF itself or from inadequate adjustment for adiposity. Moreover, the evidence examining adiposity as a modifier of this association in young adults is lacking.

Methods: A cross-sectional analytic design will be conducted to achieve the three specific aims. Participants will be recruited through flyers and emails. Inclusion criteria include young adults aged 20-34 years old, healthy (without diagnosis of disease), being capable of completing the CRF testing, and not using any hormonal therapy. After screening for eligibility, 88 participants will be enrolled and they will be scheduled for a data collection session. Data will be collected on each participant through CRF testing, anthropometric measurement and blood sampling of inflammatory biomarkers in one 
session at the University of Texas Health Science Center at Houston School of Nursing. CRF will be estimate by a submaximal treadmill test and adiposity will be assessed by body mass index and waist circumference. Inflammatory markers will be measured by enzyme-linked immunosorbent assay (ELISA). Separate analyses will be conducted with each of the inflammatory markers (hs-CRP, IL-6, and TNF- $\alpha$ ) as the dependent variable in multiple linear regression for aims one and two. Multiple linear regression models, with interaction terms $(\mathrm{CRF} \times \mathrm{BMI})(\mathrm{CRF} \times$ waist circumference $)$ will be addressed to assess aim three.

Nursing Implications: This information provides more accurate evaluation and interpretation of inflammatory biomarkers in clinical practice as related to CRF and adiposity. Additionally, these finding will be useful in understanding the physiological mechanisms of CRF, adiposity, and inflammatory biomarkers, which contributes to decreased atherosclerosis risk. Lastly, these findings will be useful in in planning preventive strategies to reduce low-grade chronic inflammation in obese as well as healthy weight young adults, which in turn delay the progression of atherosclerosis and reduce the risk of CVD events. 


\section{Specific Aims}

Chronic, low-grade vascular inflammation plays a key role in the initiation and progression of atherosclerosis (Packard \& Libby, 2008). C-reactive protein (hs-CRP), interleukin-6 (IL-6), and tumor necrosis factor- $\alpha$ (TNF- $\alpha$ ) have been documented as the major inflammatory markers associated with atherosclerotic progression and events (Packard \& Libby, 2008). It has demonstrated that atherosclerotic lesions begin early in life albeit clinical manifestations are not observed until symptoms occur in later life (Loria et al., 2007).

Cardiorespiratory fitness (CRF) has shown health benefits in reducing circulating levels of inflammatory markers, but it is still uncertain whether there is a definitive link between CRF and inflammatory biomarkers in healthy young adults (Hamer, 2007). There is also evidence that adiposity might be a factor attenuating the link of CRF with low grade inflammation (Hamer, 2007). However, no previous studies have examined the interplay of CRF and adiposity on inflammatory biomakers in healthy young adults. In this proposed study, the principal investigator (PI) will examine the associations of $\mathrm{CRF}$ and adiposity with inflammatory biomarkers and the interaction of CRF and adiposity on inflammatory biomarkers in healthy young adults aged 20 to 34 years. Adiposity is defined as body mass index (BMI) and waist circumference in this study. The PI will pursue the main purpose of this study through three specific aims as follows: Aiml. To determine the strength of the association between CRF levels with circulating levels of plasma hs-CRP, IL-6, and TNF- $\alpha$. Hypothesis: Higher levels of CRF will be related to lower levels of circulating plasma hs-CRP, IL-6, and TNF- $\alpha$. 
Aim2. To determine the strength of the association between adiposity levels and circulating levels of plasma hs-CRP, IL-6, and TNF- $\alpha$. Hypothesis: $2 a$. Higher levels of BMI will be related to higher levels of circulating plasma hs-CRP, IL-6, and TNF- $\alpha .2 b$. Higher levels of waist circumference will be related to higher levels of circulating plasma hs-CRP, IL-6, and TNF- $\alpha$.

Aim3. To test the moderating effect of adiposity on the strength of the association between CRF levels and circulating levels of plasma hs-CRP, IL-6, and TNF- $\alpha$. Hypothesis: $3 a$. Individuals with higher levels of BMI and higher levels of CRF will have lower levels of circulating plasma hs-CRP, IL-6, and TNF- $\alpha$ compared with individuals with higher levels of BMI and lower levels of CRF. $3 b$. Individuals with higher waist circumference and higher levels of CRF will have lower levels of circulating plasma hs-CRP, IL- 6 , and TNF- $\alpha$ compared with individuals with higher waist circumference and lower levels of CRF. For public health strategies and improvements of cardiovascular health, the proposed work is innovative in that it will test the central hypothesis that young adults with higher levels of CRF will have lower levels of inflammatory markers than those with lower levels of CRF, even among individuals who have greater adiposity as measured by BMI and waist circumference. Additionally, understanding the interplay of $\mathrm{CRF}$, adiposity and inflammatory markers is of great importance because it will contribute to more accurate evaluation and interpretation of inflammatory markers in clinical practice. Finally, these findings will be useful in planning interventions to reduce low-grade chronic inflammation in obese as well as healthy weight young adults, which in turn may delay the progression of atherosclerosis and reduce the risk of CVD. 


\section{Research Strategy}

\section{Significance}

Atherosclerotic cardiovascular disease (CVD) is a significant public health burden in the United States (Go et al., 2013). Atherosclerosis, a systemic disease process in which amassment of plaque builds up in the arterial wall, is the major underlying cause of the clinical CVD and CVD events (Go et al., 2013; Libby et al, 2009). It has been demonstrated that low-grade systemic vascular inflammation plays a pivotal role in the initiation and progression of atherosclerosis (Libby et al., 2009) by impairing endothelial function (Hansson, 2005; Ferri et al., 2007). Among the many inflammatory biomarkers, hs-CRP, IL-6, and TNF- $\alpha$ are well-recognized markers of inflammation in relation to atherogenesis (Calabro, Golia, \& Yeh, 2009; Haddy et al., 2003). Hs-CRP, a primitive acute phase inflammatory protein, is secreted by the liver in reaction to IL-6 and has been demonstrated to be represented in atherosclerotic plaque (Clearfield, 2005; Wilson, Ryan, \& Boyle, 2006). The "high sensitivity (hs)" term means "the measurement of CRP in serum or plasma sample using immunoassay methods with sufficient sensitivity" in asymptomatic individuals (Bajpai, Goyal, \& Sperling, 2010, p.191). IL-6 is a proinflammatory cytokine and produced by fibroblasts, endothelial cells, monocytes, and adipose tissue (Schuett, Luchtefeld, Grothusen, Grote, \& Schieffer, 2009). IL-6 plays an important role in controlling hepatic production of inflammatory proteins, including hsCRP and fibrinogen (Antuna-Puente, Feve, Fellahi, \& Bastard, 2008). TNF- $\alpha$, a proinflammatory cytokine, is secreted by macrophages, lymphocyte, and adipose tissue (Petersen $\&$ Pedersen, 2005). TNF- $\alpha$ activates the production of IL-6 in adipose tissue and blood mononuclear cells (Petersen \& Pedersen, 2005). 
Although clinical symptoms of atherosclerotic CVD, such as chest pain or discomfort, shortness of breath or fatigue, numbness, and blurred vision are not commonly detected until adulthood it is a progressive atherosclerotic process that occurs early in life and has clinical indications, including acute coronary syndrome and acute stroke usually later in life (Loria et al., 2007; Frank et al., 2010). Hence, young adults could be a main target for preventive endeavors, such as individual's health behaviors because these efforts might minimize or delay atherosclerotic process, which could eventually decrease the incidence of clinical CVD throughout middle and older adulthood (Loria et al., 2007).

CRF refers to the health-related component of physical fitness (Caspersen, Powell, \& Christenson, 1985). CRF defined as "the ability to perform large muscle, dynamic, moderate-to-high intensity exercise for prolong periods of time" (American College of Sports Medicine [ACSM], 2010b, p.71). CRF is "an individual's capacity of the cardiovascular, respiratory, and muscle systems to supply oxygen during sustained physical activity" (ACSM, 2010a, p.3). It has reported that higher levels of CRF are closely related to higher levels of habitual physical activity (Blair et al., 1995). The "gold standard" or criterion measure of CRF is maximal oxygen uptake $\left(\mathrm{VO}_{2 \max }\right)(\mathrm{ACSM}$, 2010). The $\mathrm{VO}_{2 \max }$ reflects the capacity of the heart, lungs, and blood to deliver oxygen to the working muscles during dynamic exercise involving large muscle mass (Heyward, 2010). The $\mathrm{VO}_{2 \max }$ commonly estimates either a maximal or submaximal exercise test. CRF in this study will be estimated by using a submaximal treadmill walking protocol because maximal exercise testing is not always feasible or practical in the health and research settings (Heyward, 2010). Additionally, maximal exercise testing with analysis 
of expired gases requires expensive laboratory equipment, considerable amount time, trained personnel and possible physician oversight. Further, there is considerable participant burden, associated safety considerations, and obtaining a valid estimate requires participant motivation (Heyward, 2010). The selected submaximal treadmill walking test protocol will utilize individual's heart rate (HR) response to submaximal treadmill work rates to estimate $\mathrm{VO}_{2 \max }$ (Ebbeling et al., 1991). It has reported that CRF is inversely associated with CRP in young adults (Kuo, Yen, Chen, Yu, \& Bean, 2007; Williams et al., 2005). However, it is remain uncertain whether an inverse association between $\mathrm{CRF}$ and inflammatory biomarkers is due to the health benefits of $\mathrm{CRF}$ or results from changes in adiposity (Harmer, 2007).

Adiposity is defined as "the quality or state of being fat" (Merriam-Webster Dictionary). The adiposity is a synonym for obesity or fatness (Merriam-Webster Dictionary). Adiposity has been assessed by anthropometric measures in public health and clinical practices. Adiposity in this study will be assessed by BMI and waist circumference (WC). BMI $\left(\mathrm{kg} / \mathrm{m}^{2}\right)$ has been recommended for the identification of measuring body fat (WHO, 2000) and the most widely accepted measures of overall adiposity (Stevens, McClain, \& Truesdale, 2008); however, BMI does not differentiate fat mass from bone and muscle mass and does not provide any information on the distribution of body fat, particularly central body fat (Stevens, McClain, \& Truesdale, 2008). Thus, WC will be assessed for measuring central adiposity (Stevens, McClain, \& Truesdale, 2008). A growing body of evidence has supported that there is positive association of adiposity with inflammatory biomarkers (Park, Park, \& Yu, 2005; Wang, Reed, Goli, \& Goswami, 2011). However, there is not enough evidence to identify the 
strength and patterns of association of anthropometric adiposity measures with CRP, IL-6 and TNF- $\alpha$.

Although there is evidence that CRF is inversely associated with inflammatory biomarkers (Hamer, 2007), it is still under debate whether the beneficial effect of CRF derives from the CRF itself or from inadequate adjustment for adiposity (Hamer, 2007), which adiposity also may influence in inflammatory processes (Rocha \& Libby, 2009). More importantly, only two studies have examined the association of CRF and CRP in young adults over the past decade (Kuo et al., 2007; Williams, Milne, Hancox, \& Poulton, 2005). One study measured CRP using a low sensitivity CRP assay, which may underestimate the strength of the association between CRF and inflammation (Williams et al., 2005). The other study was population-based study, which included study participants with CVD risk factors, such as hypertension, diabetes and current smokers or participants with anti-inflammatory or CVD medications (Kuo et al., 2007), thus, the findings cannot be generalized to healthy young adults. Neither study examined adiposity as moderator of the association between inflammation and CRF, and what extent that adiposity influences the association between CRF and inflammation. Furthermore, these two previous studies only focused on CRP as a biomarker of inflammation. It is essential to investigate other inflammatory markers, such as IL-6 and TNF- $\alpha$ in order to better understand inflammatory processes in relation to adiposity and CRF. Therefore, this proposed study is significant as it will provide data on the role of adiposity as a moderator of the strength of the association between CRF and three inflammatory biomarkers. This will fill an important gap in knowledge. Figurel shows a schematic diagram of the conceptual framework and specific aims of this proposed study. 
The proposed study is significant as it will

(1) Provide a basis for more accurate interpretation and evaluation of inflammatory biomarkers in clinical settings as related to CRF and adiposity assessment.

(2) Contribute a better understanding inflammatory process in relation to CRF and adiposity in a young adult population.

(3) Provide knowledge for the design of preventive strategies to reduce low grade chronic inflammation in obese as well as healthy weight young adults, which inturn may delay the progression of atherosclerosis risk and reduce the risk of CVD.

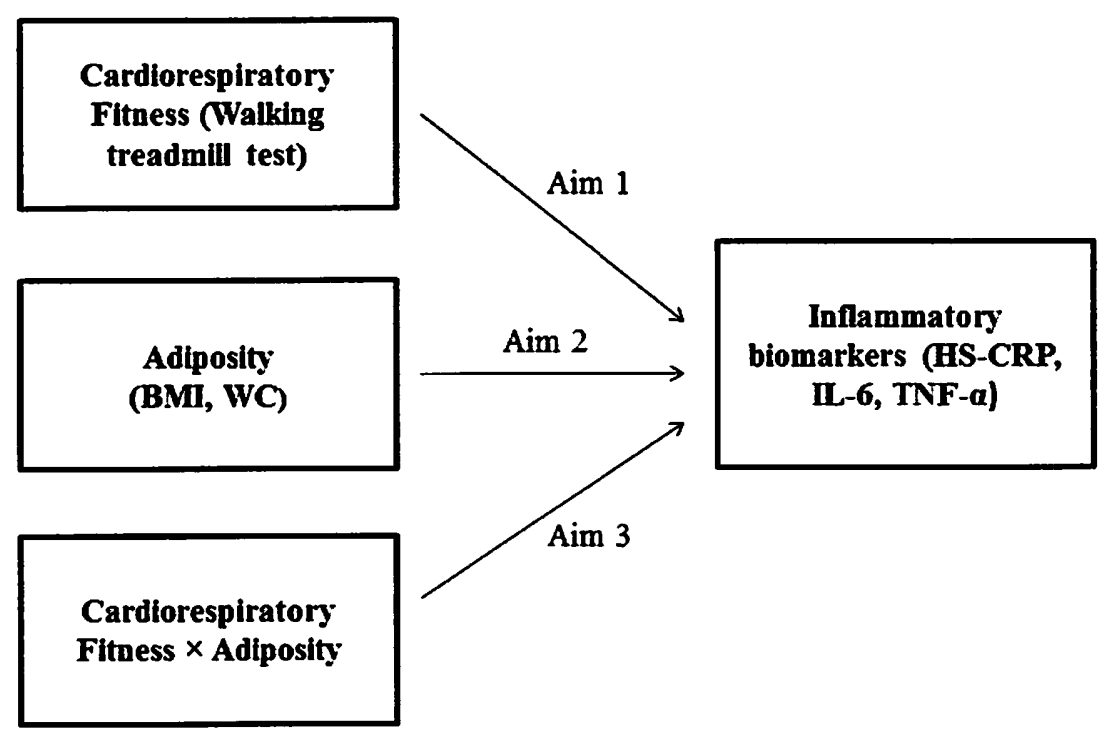

Figure 1. Conceptual framework for cardiorespiratory ntness, adiposity and inflammatory biomarkers in young adults 


\section{Innovation}

The proposed study is innovative in that it will

(1) No previous studies have examined the interplay of CRF and adiposity on inflammatory makers in young adults.

(2) Be one of the few studies that assessed CRF in young adults without known diagnosis of disease using a single-stage submaximal treadmill walking test in community setting.

(3) Provide CRF levels, adiposity levels and plasma inflammatory biomarkers levels not only hs-CRP but it also IL- 6 and TNF- $\alpha$ in young adults. To our knowledge, this is the first study to include IL-6 and TNF- $\alpha$ in relation to CRF in healthy young adults. There is limited data on these variables in young adults. This information will expand scientific knowledge on the inflammatory mechanisms related to CRF and adiposity, which may contribute to atherosclerosis risk in this population.

\section{Approach}

\section{Preliminary study.}

Effects of exercise intervention on inflammatory markers in healthy young and middle aged adults: $A$ systematic review. The PI conducted a systematic review of effects of exercise interventions on inflammatory markers in healthy young and middle aged adults (Park \&Meininger). The aim of this systematic review was to assess the effects of exercise interventions on circulating levels of inflammatory markers CRP, IL-6, and TNF- $\alpha$ in healthy young and middle aged adults. Method of this study was that Medline and PubMed databases were searched for studies published between1966 and 
July 2011 using keywords related to "exercise", "C-reactive protein", "interleukin-6", and "tumor necrosis factor-alpha". Inclusion criteria were (a) randomized controlled trials (RCTs), (b) exercise interventions with a minimum duration of 4 weeks, and (c) participants' ages 18 to 65 years old. Main findings were as follows: Of 1,490 identified publications, 93 were retrieved for detailed evaluation and 8 met inclusion criteria. Of 6 RCTs on CRP, 1 study reported decreased CRP $(\mathrm{P}<0.05)$ in aerobic exercise. Of 3 RCTs on IL-6, 1study showed decreased IL-6 (P $\leq 0.02)$ in aerobic exercise. Of 4 RCTs on TNF$\alpha, 1$ study reported elevated TNF- $\alpha(\mathrm{P}<0.05)$ in aerobic exercise among females, and 1 study demonstrated decreased TNF- $\alpha(\mathrm{P}<0.01)$ in high-intensity aerobic exercise. The evidence supporting the effects of exercise interventions on CRP, IL- 6 and TNF- $\alpha$ is sparse and inconsistent, and degree of adiposity was not considered. Further research is needed on the potential role of body fat as it relates to the effects of exercise and CR fitness on inflammatory biomarkers.

\section{Anthropometric adiposity measures and inflammatory biomarkers in}

adolescents and young adults: A systematic review. The purpose of the systematic review was to determine the associations between anthropometric adiposity measures (BMI, WC, WHR, WHtR, and BF\%) and inflammatory biomarkers (CRP, IL-6, and TNF- $\alpha$ ) in healthy adolescents and young adults without a known diagnosis of diseases. Method of this study was that MEDLINE (from 1946 to June 08, 2012), CINAHL (from 1995 to June 08, 2012), and SCOPUS (from 1960 to June 08, 2012) using keywords related to anthropometric adiposity measures;"body mass index," " waist circumference," and inflammatory biomarkers; "C-reactive protein", "interleukin-6", and "tumor necrosis factor-alpha". Inclusion criteria were (1) adolescents and young adults aged 13 to 40 
years; (2) investigated the association between at least one anthropometric adiposity measures and CRP, IL-6, and/or TNF- $\alpha$; (3) anthropometric adiposity measured by BMI, WC, WHR, WHtR, and/or body percentage assessing a skinfold thickness; (4) CRP, IL-6, and TNF- $\alpha$ levels measured by blood; (5) if cross-sectional data from the same study cohort was published in more than one studies, then only results from the report that most directly evaluated the association of anthropometric adiposity and inflammation was included; (6) all types of research designs; (7) reported in an original study; (8) no country restriction; and (9) published study in English language. Exclusion criteria were: (1) adolescent and young adults with diagnosed diseases and infectious diseases; (2) pregnant women; (3) reported adiposity measured only by DEXA or MRI; (4) reported a review or an editorial article; and (5) reported in an abstract. Main findings were as follows: Of 3,714 identified publications, 166 full text studies were retrieved for detailed evaluation and 27 met inclusion criteria. The main findings of the systematic review showed that there was significant and positive association of anthropometric adiposity measured by both total adiposity and central adiposity (BMI, WC, WHtR, WHR, and BF\%) with CRP in adolescents and young adults in 23 studies (96\%) $(p<0.05)$ and there was no significant association in adolescents in one study (4\%). The findings of the review in the associations between anthropometric adiposity measures (BMI, WC, WHR, and BF\%) with IL- 6 and TNF- $\alpha$ in adolescents and young adults remained inconsistent. Further research is needed to focus on the interplay of diet, physical activity, or weight loss with CRP, IL-6 and TNF- $\alpha$ for developing appropriate and effective lifestyle modification in reducing circulating levels of CRP, IL- 6 and TNF- $\alpha$ and in preventing further development of atherosclerotic CVD and acute CVD events in later life. 


\section{Methods}

Research design. The proposed cross-sectional analytic study is designed to achieve three specific aims. After screening for eligibility, health young adults 20-34 years old will be enrolled. Data will be collected on each participant through CRF testing, anthropometric measurement and blood sampling of inflammatory biomarkers in one session at the University of Texas Health Science Center at Houston (UTHSC-H) School of Nursing (SON).

Participants and setting. The target population for this study is healthy young adults aged 20 to 34 years residing in Houston, a large metropolitan city and with an ethnically diverse population in southeast Texas. Adults can be divided into young adulthood (the 20s and 30s), middle adulthood (the 40s and 50s), and later adulthood (age 60 or 65 and up) based on developmental periods in the human lifespan (Craig \& Dunn, 2010). The focus of this study is on young adults aged 20 to 34 without a known diagnosis of diseases because women's menopause occurs after age of 40 to 45 and perimenopause typically begins several years before menopause. A sample of the population will be accessed using non-probability quota sampling approach in the area of UTHSC-H.

Sample size. Sample size was estimated based on a multiple linear regression model, regression coefficient $\left(\mathrm{R}^{2}\right)$ with interactions using nQuery Advisor version 7.0 (nQuery, Saugus, MA). The estimated sample size was 88 subjects to detect a medium effect size $\left(0.059 \leq \mathrm{R}^{2}<0.138\right)$ according to Jacob Cohen $(1998)$, a power of $80 \%$, and an alpha level of 0.050 for a two-tailed test. With a sample size of 88 , the interaction of adiposity and CRF would be stated by at $p<0.05$ if the change in $R^{2}$ with the addition of 
the interaction term were as lower at 0.069 . To address possible attrition up to $20 \%, 110$ participants will be recruited. Since there were no previous studies to estimate for the interaction term, the PI chose the medium $\left(R^{2}\right)$ of 0.069 for interactions for a multiple linear regression model in this study.

Inclusion and exclusion criteria. Inclusion criteria are (1) young adults age 20-34 years; (2) healthy (defined as "not currently having acute or chronic diseases" as specified in exclusion criteria); (3) capable of completing the CRF test and there is no minimal or maximal value for $\mathrm{VO}_{2}$ max as long as participants are physically able to do CRF testing safely (ACSM, 2010a; ACSM, 2010b); and (4) able to speak and read English. Exclusion criteria are as follows in both males and females: (1) currently nonsmoker or smoking cessation greater than lyear because smoking status may increase hsCRP, IL-6 and possibly certain cytokine receptors antagonists (O'Connor et al., 2009); (2) alcohol dependence or regular consumption of more than 7 servings per week because alcohol intake alters inflammatory biomarkers (O'Connor et al., 2009 ); (3) acute infections, including a current or recent influenza illness, recent flu shot recipients, acute respiratory infection within 2 weeks; (4) dental infection and problem within 2 weeks; (5) CVD, such as hypertension, heperlipidemia and diabetes mellitus type I or II; (6) rheumatoid arthritis and immune disorders because of the possible alteration of inflammatory markers; (7) history of inflammatory bowel disease, such as Crohn's disease and ulcerative colitis; (8) recent surgery within 1 month; (9) currently taking medications, such as hormone replacement therapy, antihypertensive medications, allergy shots or systemic corticosteroids, aspirin, statin, and selective serotonin uptake inhibitors (SSRIs), and anti-inflammatory medications, all of which may impact levels of 
circulatory inflammatory biomarkers (O'Connor et al., 2009); (10) history of orthopedic injury in the past and limitations due to the musculoskeletal demands of CRF test (11) other medical conditions and medications that would increase inflammatory markers and would prohibit CRF test; and (12) the maximum hs-CRP cut off point will be set at 10.0 $\mathrm{mg} / \mathrm{L}$ which may have potentially reflected inflammation due to sepsis and an acute infection or other inflammatory conditions (Pearson et al., 2003). For females, inclusion criteria are as follows: (1) self-reported menstrual cycle length of 24-35 days during the 2 months before entering the study; and (2) self-reported without a menstrual period at the time of data collection because menses may impact increased levels of CRP (Gaskins et al., 2012). Exclusion criteria are as follows: (1) natural or surgical menopausal status; (2) use of hormone replacement therapy (HRT); (3) not currently or recently (past 6 months) pregnant status; (4) not currently or recently (past 2 months) lactating females because breast feeding may influence CRP (Williams, Williams \& Poulton, 2006); (5) history of gynecologic problems, such as fibroids, endometriosis, or polycystic ovary syndrome because these gynecologic problems have been reported to increase CRP (EscobarMorreale, Luque-Ramírez, \& González, 2011); (6) hormonal contraception use within the past three months, such as hormone patch and vaginal ring methods; and (7) IUDs with hormones and Depo-Provera within the past 12 months, which of all may increase inflammatory biomarkers (Gaskins et al., 2011; O'Connor et al., 2009). Those taking oral contraceptives will not be excluded from the study, but data on this variable will be collected so that it can be included as a covariate in the analysis.

Setting for data collection. The data will be collected by the PI at the Center for Nursing Research, and a biological sciences laboratory in the UTHSC-H SON. Data 
collection will be performed in a CRF study room in the UTHSC-H SON. The room will be maintained between 68 and 76 degrees Fahrenheit, with a humidity level between 20 to 60 percent using a room temperature thermometer (Q-Track IAQ monitor, TSI Incorporated, Shoreview, MN) throughout the data collection period based on the Occupational Safety and Health Administration recommendations (2003).

Recruitment of subject and data collection procedure. Participants will be recruited by posting fliers in the UTHSC-H and surrounding communities of UTHSC-H as well as by sending e-mails to students and employees of the UTHSC-H. The recruitment will begin from the end of November 2012 through December 2013. Time frame of project activity is provided (Appendix F). A flyer and email will describe the need for healthy young adult volunteers, age 20-34 years, of all fitness and weight levels. The flyers will include a very brief description of the study, and will provide the PI's phone number and e-mail address for further information (Appendix A). If participants are interested in the study, they will contact the PI. The PI will provide detailed information on the study, including the purpose of the study, study procedures, data collection plan, and potential risks and benefits. During a telephone interview, the PI will screen participant's eligibility. When participants meet the inclusion criteria and they show an interest in participating in the study, they will be scheduled to attend a data collection session in the UTHSC-H SON. For preparation of data collection, participants will be instructed (1) not to eat after $8 \mathrm{pm}$ the night or 12 hours before the testing; (2) not to do strenuous exercise, consume alcohol, or use anti-inflammatory drugs 24 hours prior to blood sampling; (3) to arrive at the UTHSC-H SON bioscience laboratory between $8 \mathrm{am}$ and $10 \mathrm{am}$; (4) to wear comfortable exercise-type clothing; (5) to avoid tobacco and 
caffeine 3 hours prior to test; (6) to consume plenty of fluids; and (7) to obtain an adequate amount of sleep the night before the test (ACSM a, 2010; ACSM b, 2010). Because inflammatory markers are elevated during menstruation, women participants will be scheduled for a day when they are not menstruating (Gaskins et al., 2011). Before collecting the data, informed consent will be obtained by the PI. The PI will thoroughly explain and will clarify any information on this study. After obtaining informed consent, each participant will complete an interview guided pre-assessment health questionnaire (ACSM a, 2010). The questionnaire was designed to identify whether the participants are safe to test for CRF (ACSM a, 2010). If the participant will not be safe to perform CRF testing, he or she will be excluded such as high blood pressure, short of breath, chest pain, heart palpitation, heart murmur, fainting, back pain and intermittent leg pain. Once the participant is eligible to perform CRF testing, the eligible participant's blood test will be collected between 8am and 10am. After collecting blood samples, anthropometric characteristics (height, weight and waist circumference) will be measured. A light snack and water will be provided. After a brief resting period, the PI will conduct CRF testing. The CRF test will take 20-30 minutes of walking on the treadmill including warm-up and cool down stages. Participants who complete all procedures will be compensated with a $\$ 10$ gift card. All procedures will be conducted by the PI. The results of CRF levels, body anthropometric measurements and levels of inflammatory markers will be released for participants who show an interest in knowing their results. Procedures for obtaining informed consent and all protocols will be approved by the Committee for the Protection of Human Subjects at the UTHSC-H. 


\section{Instruments.}

Demographic characteristics. The PI will complete pre-assessment questionnaire regarding demographic and health-related information, lifestyle, and activity levels from participant's self-report. The pre-assessment questionnaire was developed by ACSM (2010a).The demographic information includes information on age, gender, ethnicity, marital status, and education. Age, gender, ethnicity and education will be described participants' characteristics and be used as covariates in the multiple regression analysis.

Assessment of CRF. CRF will be assessed by a single-stage submaximal treadmill walking test (SSTWT). The SSTWT was developed by Ebbeling et al. (1991) for estimating $\mathrm{VO}_{2}$ max of low-risk, healthy adults 20 to 50 years. The SSTWT was validated by correlating the indirectly estimated $\mathrm{VO}_{2} \max$ based on individual's walking speed, heart rate (HR), age and sex and the directly measured respiratory gas exchange $\left(\mathrm{VO}_{2} \mathrm{max}\right)$ in the cross-validation group $(\mathrm{N}=22)$ (Ebbeling et al., 1991). A correlation $(r)$ of .96 was reported, with multiple correlation $\left(\mathrm{R}^{2}\right)$ of $.86\left(\mathrm{SEE}=4.85 \mathrm{ml} \cdot \mathrm{kg}^{-1} \cdot \mathrm{mim}^{-1}\right)$ (Ebbeling et al., 1991).

Single-stage submaximal treadmill walking test protocol. The SSTWT consisted of a 4-minute warm-up stage, 4-minute workload stage, and a 2-5minute cooldown stage. The treadmill will be calibrated before CRF test to ensure the accuracy of the test. Prior to beginning the SSTWT, participants will be familiarized with the treadmill (Precor 956i, Precor, Inc., Woodinville, WA), including a visual demonstration in order to maximize participant safety.

In the first warm-up stage, participants will walk on the treadmill for a 4-minute at $0 \%$ incline and a walking speed ( 2.0 to $4.5 \mathrm{mph}$ ) that brings the HR to between $50 \%$ 
and $70 \%$ beats per minute (bpm) age-predicted maximal HR by the PI. In workload stage, the treadmill incline will increase to $5 \%$ at the same speed for a 4-to 5-minute. Following a workload stage, the participants will complete a cooldown stage at a slow walk and $0 \%$ incline for a 2-5minute. Resting BP and HR using the oscillometric technique (HEM907SL, Omron Healthcare, Inc., Bannockburn, IL) will be assessed prior to a warm-up stage, twice and after a cool-down stage one time. If the participant's resting blood pressure $\geq 130 / 90 \mathrm{mmHg}$ or resting $\mathrm{HR} \geq 100$ per minute, the participant will not be allowed to have a SSTWT. Polar HR (Vintage NV model, Polar CIC, Inc., Port Washington, NY) will be recorded during the SSTWT protocol and the Borg Ratings of Perceived Exertion scale (RPE) will be documented at the end of the warm-up stage and the workload stage. The Borg Scale takes into account a participant's fitness level. It matches how hard he or she feels he or she is working with numbers from 6 (very, very light) to 20 (very, very hard) (Borg, 1970). Steady-state HR defines as a HR within \pm 5 bpm during the last 2 minute of the workload stage.

The main outcome of the CRF test will be estimated maximal oxygen uptake $\left(\mathrm{VO}_{2} \max \right)$. The SSTWT prediction equation will be used to estimate $\mathrm{VO}_{2}$ max based on age, sex, walking speed (mph), and steady-state HR.

Estimated VO2 $\max (\mathrm{ml} \cdot \mathrm{kg}-1 \cdot \min -1)=15.1+21.8($ speed in $\mathrm{mph})-0.327($ steady state HR in bpm) - 0.263 (speed $x$ age in years) +0.00504 (SS HR in bpm age in years $)+5.98(\operatorname{sex} ;$ female $=0$, male $=1)$

Assessment of adiposity. Adiposity will be assessed using BMI and waist circumference. BMI will be calculated by dividing the participant's weight in kilograms by the height in meters squared $\left(\mathrm{kg} / \mathrm{m}^{2}\right)$. Height will be measured without shoes to the 
nearest $0.1 \mathrm{~cm}$ using a wall-mounted stadiometer (Accustat, Genentech Inc.). Weight will be measured to the nearest $1 / 4^{\text {th }} \mathrm{Ib}$ with a calibrated balance beam scale. Height and weight will be measured with minimal clothing and without shoes and hats (NHANES, 2010). Waist circumference (WC) is a measure of the degree of central of body fat. WC will be measured to the nearest $0.1 \mathrm{~cm}$ using a flexible, nonstrectchable tape. The tape measure will be placed just above the uppermost lateral border of the right ilium crest and will be extended around the waist in a horizontal plane (NHANES, 2010).

Measurement of $h s-C R P, I L-6$, and $T N F-\alpha_{\text {. }}$ Prior to blood sample collection, the PI will ascertain that the participant is comfortable with instructions and procedures for collecting blood sample. A $10 \mathrm{ml}$ fasting blood will be collected from an antecubital vein into two vacutainers containing ethylene diamine tetra acetic acid (EDTA) vacutainers by the PI. After collecting two EDTA vacutainers, the blood samples will be transported to the Bioscience Laboratory in the UTHSC-H SON on dry ice pellets with ice designed for frozen temperature to maintain that temperature. The blood samples will be immediately centrifuged at 1,630 relative centrifugal force $(\mathrm{rcf})$ at $-4^{\circ} \mathrm{C}$ for 30 minutes (Centrifuge5810R, Eppendorf AG Hamburg, Germany). After centrifugation, plasma samples will be divided into eight aliquots. Each cryo-tube will be labeled in numerical order of the participant study identification, date, year, and stored at $-80^{\circ} \mathrm{C}$ for up to a maximum of one year.

Plasma hs-CRP will be determined by a sandwich ELISA (Alpco C-reactive protein (hs-CRP), EIA, Salem, N.H., USA). Plasma hs-CRP will present in milligram per liter $(\mathrm{mg} / \mathrm{L})$. Intra- and inter-assay coefficients of variation are less than $2 \%$. Plasma IL-6 concentration will be measured using the BIOSOURCE Enzyme Amplified Sensitivity 
Immunoassay (EASIA) kit (BioSource, Nivelles, Belgium). Plasma TNF- $\alpha$ will be quantified using a solid phase sandwich ELISA (ALPCO Diagnostics). Plasma IL-6 and TNF- $\alpha$ will be represent in pictogram per milliliter $(\mathrm{pg} / \mathrm{ml})$. Plates of biomarkers will be read on a microplate reader using absorbance (Bioteck instruments Inc., Winooski, VT). WorkOut $^{\mathrm{TM}}$ software (version 2.5, Perkin Elmer Life and Analytical Sciences) will be used for analyzing assay results. Intra- and inter-assay coefficients of variation will be below $10 \%$. All inflammatory biomarkers will be assayed at the Bioscience Laboratory at the UTHSC-H SON for this study.

\section{Data Analysis}

Statistical analyses will be performed by using statistical software SPSS version 22.0 (SPSS Inc., Chicago, IL). Descriptive statistics will be used to summarize characteristics of study participants, including mean, standard deviation, frequency and percentage. For continuous variables, histograms, box plots, and normality probability plot will be used to identify normality of distribution, outliers, and missing data. Appropriate transformations will be performed where necessary. All analyses will be two-tailed and P-value $<0.05$ will be considered statistically significant. Separate analysis will be conducted with each of the inflammatory markers (hs-CRP, IL6 , and TNF- $\alpha$ ) as the dependent variable in multiple linear regression analysis for aim 1: the strength of the association between CRF and inflammatory biomarkers, and the aim 2: the strength of the association between adiposity and inflammatory biomarkers. Analyses for aim 1 and 2 will be adjusted for possible confounders including age, sex, ethnicity and education. 
Aiml. To determine the strength of the association between CRF levels with circulating levels of plasma hs-CRP, IL-6, and TNF- $\alpha$. Hypothesis: Higher levels of CRF will be related to lower levels of circulating plasma hs-CRP, IL-6, and TNF- $\alpha$.

Aim2. To determine the strength of the association between adiposity levels and circulating levels of plasma hs-CRP, IL-6, and TNF- $\alpha$. Hypothesis: 2a. Higher levels of BMI will be related to higher levels of circulating plasma hs-CRP, IL- 6 , and TNF- $\alpha$. $2 b$. Higher levels of waist circumference will be related to higher levels of circulating plasma hs-CRP, IL-6, and TNF- $\alpha$.

Multiple linear regression models, with interaction terms $(\mathrm{CRF} \times \mathrm{BMI})(\mathrm{CRF} \times$ waist circumference) will be examined to assess aim 3: the moderating effect of adiposity (moderator) on the strength of the association of CRF (independent variable) with inflammatory biomarkers (dependent variable). Analyses for aim 3 will be adjusted for possible confounders including age, gender, ethnicity and education.

Aim3. To test the moderating effect of adiposity on the strength of the association between CRF levels and circulating levels of plasma hs-CRP, IL-6, and TNF- $\alpha$. Hypothesis: $3 a$. Individuals with higher levels of $\mathrm{BMI}$ and higher levels of CRF will have lower levels of circulating plasma hs-CRP, IL-6, and TNF- $\alpha$ compared with individuals with higher levels of BMI and lower levels of CR fitness. $3 b$. Individuals with higher waist circumference and higher levels of CRF will have lower levels of circulating plasma hs-CRP, IL-6, and TNF- $\alpha$ compared with individuals with higher waist circumference and lower levels of CRF. 


\section{Limitations}

Firstly, a weakness of this study is the difficulty of establishing causal relationships from data collected in a cross-sectional time frame. Secondly, a nonprobability sampling method in a university setting will limit generalization of the findings of this study. In spite of these limitations, the findings will provide important knowledge about inflammatory markers in young adults and will be used for designing longitudinal studies and interventions to improve cardiovascular health in this target population.

\section{Facilities/Resources/Consultants}

Center for Nursing Research for CR fitness and bioscience laboratory for handling and analyzing inflammatory biomarkers at the UTHSC-H SON are available for the conduct of this project. Additionally, statisticians to assist with data management and analysis are available. Lastly, fitness experts at UTHSC-H Recreation Center and School of Public Health are available for consultation.

\section{Human Subjects Concerns}

Protection of human subjects. Protection of human subjects' rights will be assured with obtaining appropriate approval from the University of Texas Health Science Center at Houston Committee for Protection of Human Subjects (UTHSC-H CPS). The PI will be trained on Collaborative Institutional Training Initiative (CITI) and iRIS. The PI will thoroughly explain the purpose and overall procedure of the study, and potential benefits and risks of participating in the study prior to obtaining informed consent. Participants will be informed that if they are unwilling to participate in this study, they can withdraw at any time. Participants will be allowed and encouraged to ask any 
questions regarding the study before completing the informed consent process with a signature. No data will be collected before informed consent. Information regarding protection of privacy and confidentiality, and how the data will be handled with confidentiality will be provided to the participants.

Potential benefits and risk of the proposed study to the subjects. Participants may benefit from learning about physical inactivity, body fatness and weight as related to risk for cardiovascular disease. Participants will be informed of potential discomforts and risks as related to $\mathrm{CR}$ fitness and blood sampling. With regards to blood test, participants may feel some pain and have a bruise at the needle site. There might be a risk for developing an infection at the needle site but this is rare. In relation to CR fitness, participants may feel some discomforts during and after fitness test. These include dizziness and fainting but these effects are rare. The trained professional is available to assist with unusual situations that may arise. If participants are interested in their results, they will be received a copy of their results.

Data and safety monitoring plan. The PI will be responsible for monitoring and managing data safety and analysis procedures. Each participant will be given a study identification number. Forms and documents will be kept separate from the data file and kept in a locked cabinet. Data files and blood samples will be coded by the study identification numbers. Confidentiality of the data will be assured through coding systems without specific participant's identifiers. Protected data will be entered into a double password protected computer database with restricted access to the system.

Inclusion of minorities, women, and children. The target population of this proposed study is healthy young adults aged 20-34 years. This study population will 
include diverse ethnic groups, such as African American, Asian, and Hispanic. This study will exclude children, adolescents, elderly, and pregnant women. 


\section{References}

Adiposity. (n.d.). In Merriam-Webster's online dictionary ( $11^{\text {th }}$ ed.). Retrieved from http://www.merriam-webster.com/medical/adiposity

American College of Sports Medicine (2010a). ACSM's health-related physical fitness assessment manual. 3rd ed. Philadelphia, PA: Lippincott, Williams \& Wilkins. American College of Sports Medicine (2010b). Guidelines for exercise testing and prescription. 8th ed. Philadelphia, PA: Lippincott, Williams \& Wilkins.

Antuna-Puente, B., Feve, B., Fellahi, S., \& Bastard, J. P. (2008). Adipokines: The missing link between insulin resistance and obesity. Diabetes \& Metabolism, 34(1), 2-11. doi:10.1016/j.diabet.2007.09.004

Bajpai, A., Goyal, A., \& Sperling, L. (2010). Should we measure C-reactive protein on earth or just on JUPITER? Clinical Cardiology, 33(4), 190-198. doi: $10.1002 /$ clc. 20681

Blair, S. N., Kohl, H. W.,3rd, Barlow, C. E., Paffenbarger, R. S.,Jr, Gibbons, L. W., \& Macera, C. A. (1995). Changes in physical fitness and all-cause mortality. A prospective study of healthy and unhealthy men. JAMA : The Journal of the American Medical Association, 273(14), 1093-1098.

Borg, G. (1970). Perceived exertion as an indicator of somatic stress. Scandinavian Journal of Rehabilitation Medicine, 2(2), 92-98.

Calabro, P., Golia, E., \& Yeh, E. T. (2009). CRP and the risk of atherosclerotic events. Seminars in Immunopathology, 31(1), 79-94. doi: 10.1007/s00281-009-0149-4 
Caspersen, C. J., Powell, K. E., \& Christenson, G. (1985). Physical activity, exercise and physical fitness: Definitions and distinctions for health-related research. Public Health Reports, 100(2), 126-131.

Clearfield, M. B. (2005). C-reactive protein: A new risk assessment tool for cardiovascular disease. The Journal of the American Osteopathic Association, 105(9), 409-416. Retrieved from http://www.jaoa.org/content/105/9/409.full.pdf+html

Cohen, J. (1998). Statistical power analysis for the behavioral sciences ( ${ }^{\text {nd }}$ ed.). Hills dale, $\mathrm{NJ}$ : Eribaum.

Craig, G. J. ,\& Dunn, W. L. (2010). Understanding human development. $2^{\text {nd }}$ ed. Upper Saddle River, NJ: Pearson Education, Inc

CRP ELISA Kit for the in vitro determination of c-reactive protein in serum, plasma, stool and urine. (2012). ALPCO Diagnostic.

Ebbeling, C. B., Ward, A., Puleo, E. M., Widrick, J., \& Rippe, J. M. (1991).

Development of a single-stage submaximal treadmill walking test. Medicine and Science in Sports and Exercise, 23(8), 966-973.

Escobar-Morreale, H. F., Luque-Ramírez, M., \& González, F. (2011). Circulating inflammatory markers in polycystic ovary syndrome: A systematic review and metaanalysis. Fertility and Sterility, 95(3),1048-1058.e2. doi:

10.1016/j.fertnstert.2010.11.036

Ferri, C., Croce, G., Cofini, V., De Berardinis, G., Grassi, D., Casale, R., . . Desideri, G. (2007). C-reactive protein: Interaction with the vascular endothelium and possible 
role in human atherosclerosis. Current Pharmaceutical Design, 13(16), 16311645.

Franks, P. W., Hanson, R. L., Knowler, W. C., Sievers, M. L., Bennett, P. H., \& Looker, H. C. (2010). Childhood obesity, other cardiovascular risk factors, and premature death. The New England Journal of Medicine, 362(6), 485-493. doi:10.1056/NEJMoa0904130

Gaskins, A. J., Wilchesky, M., Mumford, S. L., Whitcomb, B. W., Browne, R. W., Wactawski-Wende, J., ... Schisterman, E. F. (2012). Endogenous reproductive hormones and $\mathrm{C}$-reactive protein across the menstrual cycle: The BioCycle study. American Journal of Epidemiology, 175(5), 423- 431.

Go, A. S., Mozaffarian, D., Roger, V. L., Benjamin, E. J., Berry, J. D., Borden, W. B., . . American Heart Association Statistics Committee and Stroke Statistics Subcommittee. (2013). Heart disease and stroke statistics--2013 update: A report from the american heart association. Circulation, 127(1), e6-e245. doi: 10.1161/CIR.0b013e31828124ad; 10.1161/CIR.0b013e31828124ad

Haddy, N., Sass, C., Droesch, S., Zaiou, M., Siest, G., Ponthieux, A., . . Visvikis, S. (2003). IL-6, TNF- $\alpha$ and atherosclerosis risk indicators in a healthy family population: The STANISLAS cohort. Atherosclerosis, 170(2), 277-283. doi: $10.1016 / \mathrm{S} 0021-9150(03) 00287-9$

Hamer, M. (2007). The relative influences of fitness and fatness on inflammatory factors. Preventive Medicine, 44(1), 3-11. Retrieved from http://dx.doi.org.www5.sph.uth.tmc.edu:2048/10.1016/j.ypmed.2006.09.005 
Hansson, G. K. (2005). Inflammation, atherosclerosis, and coronary artery disease. The New England Journal of Medicine, 352(16), 1685-1695. doi:

10.1056/NEJMra043430

Heyward, H. V. (2010). Advanced fitness assessment and exercise prescription. $6^{\text {th }}$ ed. Champaign, IL; Human Kinetics.

IL-6 EIA for the quantitative determination of IL-6 in serum, plasma, buffered solution or cell culture medium.(2008). ALPCO Diagnostic.

Isasi, C. R., Deckelbaum, R. J., Tracy, R. P., Starc, T. J., Berglund, L., \& Shea, S. (2003). Physical fitness and C-reactive protein level in children and young adults: The Columbia university BioMarkers study. Pediatrics, 111(2), 332-338.

Kuo, H. K., Yen, C. J., Chen, J. H., Yu, Y. H., \& Bean, J. F. (2007). Association of cardiorespiratory fitness and levels of C-reactive protein: Data from the National Health and Nutrition Examination Survey 1999-2002. International Journal of Cardiology, 114(1), 28-33. doi:10.1016/j.ijcard.2005.11.110

Libby, P., Ridker, P. M., \& Hansson, G. K. (2009). Inflammation in atherosclerosis: From pathophysiology to practice. Journal of the American College of Cardiology, 54(23), 2129-2138. doi:10.1016/j.jacc.2009.09.009

Loria, C. M., Liu, K., Lewis, C. E., Hulley, S. B., Sidney, S., Schreiner, P. J., . . Detrano, R. (2007). Early adult risk factor levels and subsequent coronary artery calcification: The CARDIA study. Journal of the American College of Cardiology, 49(20), 2013-2020. doi:10.1016/j.jacc.2007.03.009 
National Health and Nutrition Examination Survey (NHANES) (2009). Anthropometric procedures manual. Center for Disease Prevention. Retrieved from www.cdc.gov/nchs/data/nhanes/nhanes_03_04/BM.pdf

nQuery Advisor (2011). nQuery advisor sample size software. Saugus, MA: Statistical Solution.

O'Connor, M. F., Bower, J. E., Cho, H. J., Creswell, J. D., Dimitrov, S., Hamby, M. E., ... Irwin, M. R. (2009). To assess, to control, to exclude: Effects of biobehavioral factors on circulating inflammatory markers. Brain, Behavior, \& Immunity, 23(7), 887-897. Retrieved from

http://dx.doi.org/10.1016/j.bbi.2009.04.005

Occupational Safety and Health Administration (2003). OSHA Policy on Indoor Air Quality: Office Temperature/Humidity and Environmental Tobacco Smoke. Retrieved from http://www.osha.gov/pls/oshaweb/owadisp.show_document?ptable=INTERPRET ATIONS\&p_id $=24602$

Packard, R. R., \& Libby, P. (2008). Inflammation in atherosclerosis: From vascular biology to biomarker discovery and risk prediction. Clinical Chemistry, 54(1), 2438. doi:10.1373/clinchem. 2007.097360

Park, E. \& Meininger, J. C. Effects of exercise interventions on inflammatory markers in young and middle aged adults: A systematic review (In preparation for submission). 
Park, H. S., Park, J. Y., \& Yu, R. (2005). Relationship of obesity and visceral adiposity with serum concentrations of CRP, TNF-alpha and IL-6. Diabetes Research and Clinical Practice, 69(1), 29-35. doi:10.1016/j.diabres.2004.11.007

Pearson, T. A., Mensah, G. A., Alexander, R. W., Anderson, J. L., Cannon, R. O.,3rd, Criqui, M., ... American Heart Association. (2003). Markers of inflammation and cardiovascular disease: Application to clinical and public health practice: A statement for healthcare professionals from the centers for disease control and prevention and the American Heart Association. Circulation, 107(3), 499-511.

Petersen, A. M., \& Pedersen, B. K. (2005). The anti-inflammatory effect of exercise. Journal of Applied Physiology, 98(4), 1154-1162. doi:10.1152/japplphysiol.00164.2004

Rocha, V. Z., \& Libby, P. (2009). Obesity, inflammation, and atherosclerosis. Nature Reviews.Cardiology, 6(6), 399-409. doi:10.1038/nrcardio.2009.55

Schuett, H., Luchtefeld, M., Grothusen, C., Grote, K., \& Schieffer, B. (2009). How much is too much? interleukin-6 and its signalling in atherosclerosis. Thrombosis and Haemostasis, 102(2), 215-222. doi:10.1160/TH09-05-0297

SPSS. (2011). Statistical package for the social sciences. Chicago, IL:IBM.

Stevens, J., McClain, J. E., \& Truesdale, K. P. (2008). Selection of measures in epidemiologic studies of the consequences of obesity. International Journal of Obesity (2005), 32 Suppl 3, S60-6. doi:10.1038/ijo.2008.88

TNF- $\alpha$ ELISA for the quantitative determination of TNF- $\alpha$ in serum, plasma, buffered solution or cell culture medium. (2011). ALPCO Diagnostic. 
Wang, S., Reed, D. B., Goli, S., \& Goswami, D. (2011). Blood leptin and C-reactive protein provide more sensitive assessment than blood lipids and other inflammatory biomarkers in overweight university students. Nutrition Research, 31(8), 586-593. doi:10.1016/j.nutres.2011.07.006

WHO (2000). Obesity: Preventing and managing the global epidemic. Report of a WHO consultation. World Health Organization Technical Report Series, 894, i-xii, 1253.

Williams, M. J., Milne, B. J., Hancox, R. J., \& Poulton, R. (2005). C-reactive protein and cardiorespiratory fitness in young adults. European Journal of Cardiovascular Prevention and Rehabilitation: Official Journal of the European Society of Cardiology, Working Groups on Epidemiology \& Prevention and Cardiac Rehabilitation and Exercise Physiology, 12(3), 216-220.

Williams, M. J. A., Williams, S. M., \& Poulton, R. (2006). Breast feeding is related to C reactive protein concentration in adult women. Journal of Epidemiology and Community Health, 60(2), 146-148, doi: 10.1136/jech.2005.039222

Wilson, A. M., Ryan, M. C., \& Boyle, A. J. (2006). The novel role of C-reactive protein in cardiovascular disease: Risk marker or pathogen. International Journal of Cardiology, 106(3), 291-297. doi: 10.1016/j.ijcard.2005.01.068 
Anthropometric Adiposity Measures and Inflammatory Biomarkers in Adolescents and Young Adults: A Systematic Review Eunduck Park, MSN, RN

The University of Texas Health Science Center at Houston

School of Nursing 


\begin{abstract}
Background

Overweight and obesity are major risk factors for cardiovascular disease (CVD) morbidity and mortality. Low- grade chronic inflammation may be a mediating factor in the association of overweight and obesity with development of atherosclerosis and higher risk for CVD and CVD events. C-reactive protein (CRP), interleukin-6 (IL-6), and tumor necrosis factor-alpha (TNF- $\alpha$ ) are well-recognized markers of inflammatory response to atherosclerosis.
\end{abstract}

\title{
Purpose
}

The purpose of the systematic review was to determine the associations between anthropometric adiposity measures (BMI, WC, WHR, WHtR, and BF\%) and inflammatory biomarkers (CRP, IL-6, and TNF- $\alpha$ ) in adolescents and young adults.

\section{Methods}

The electronic databases Ovid MEDLINE, CINAHL, and SCOPUS were searched for studies published between 1946 and July 2013. Inclusion criteria were (a) adolescents and young adults aged 13 to 40 years without a known diagnosis of diseases (b) examined the association between at least one anthropometric adiposity measures and CRP, IL-6, and /or TNF- $\alpha$, and (c) published study in English language.

\section{Results}

Of 4,876 identified publications, 176 were retrieved for detailed evaluation and 28 met inclusion criteria. There is a significant and positive association between anthropometric adiposity measured by total and central adiposity (BMI, WC, WHtR, WHR, and BF\%) and CRP in adolescents and young adults in 22 out of 23 studies (96\%). Findings of 
anthropometric adiposity measures (BMI, WC, WHR, and BF\%) and IL- 6 and TNF- $\alpha$ in adolescents and young adults remain inconclusive. No single anthropometric adiposity measures in adolescents and young adults would appear to be superior in relation to CRP, IL- 6 and TNF- $\alpha$.

\section{Conclusions}

The evidence supports that anthropometric adiposity measures are positively associated with CRP in adolescents and young adults. However, anthropometric adiposity measures and IL- 6 and TNF- $\alpha$ in adolescents and young adults is inconclusive. Additional studies are needed to identify the strength and patterns of association of anthropometric adiposity measures with CRP, IL- 6 and TNF- $\alpha$. Further studies are needed to identify sex and ethnicity differences in the association of anthropometric adiposity measures and inflammatory biomarkers.

Keywords: body mass index; waist circumference; waist to hip ratio; waist to height ratio; body fat percentage; c-reactive protein; interlukin-6; tumor necrosis factor- $\alpha$; adolescents; young adults 
Anthropometric Adiposity Measures and Inflammatory Biomarkers in Adolescents and Young Adults: A Systematic Review

Atherosclerosis is a systemic disease process in which accumulation of plaque builds up in the arterial wall and a main pathophysiological determinant of clinical cardiovascular events, morbidity and mortality (Go et al., 2013). It has been shown that chronic, low-grade inflammation plays an important role in the initiation and progression of atherosclerosis by impairing endothelial function (Libby, Ridker, \& Hansson, 2009; Widlansky, Gokce, Keaney, \& Vita, 2003). The endothelial dysfunction promotes development, progression, and clinical expression of atherosclerosis, such as an acute atherosclerotic event (Bucdkley, Rongwei, Freeman, Rogers, \& Helfand, 2009; Packard \& Libby, 2008; Wildansky et al., 2003). C-reactive protein (CRP), interleukin-6 (IL-6), and tumor necrosis factor- $\alpha$ (TNF- $\alpha$ ) are well-recognized biomarkers of inflammation in relation to atherogenesis (Libby et al., 2009). CRP, a primitive acute phase inflammatory protein, plays an essential role in innate immune response and inflammatory processes (Wilson, Ryan, \& Boyle, 2006). CRP is primarily produced in the liver and is synthesized by hepatocytes in response to inflammatory cytokines, mainly IL-6 (Wilson et al., 2006). IL-6 is a pro-inflammatory cytokine that play a major role in the acute phase response in relation to infection and is produced by various cells, such as fibroblasts, endothelial cells, monocytes, and adipocytes (Schuett, Luchtefeld, Grothusen, Grote, \& Schieffer, 2009). The important role of IL-6 is controlling hepatic production of inflammatory proteins, including CRP (Schuett et al., 2009). TNF- $\alpha$ is a pro-inflammatory cytokine that is secreted by various cells, such as macrophages, lymphocyte, and adipocytes (Petersen \& Pedersen, 2005). 
The prevalence of overweight and obesity is a significant public health problem worldwide, and it has grown substantially over the past few decades (Lobstein, Baur, \& Uauy, 2004; World Health Organization [WHO], 2012). It is estimated that worldwide obesity has more than doubled since 1980 (WHO, 2012). Overweight and obesity are considered major risk factors for cardiovascular disease (CVD) mortality and morbidity (Roger et al., 2012; WHO, 2012). The underlying mechanisms for the relationship of overweight and obesity with CVD have not been fully elucidated. A growing body of evidence indicates that chronic inflammation may be a mediating factor in the association of obesity with development of atherosclerosis (Mathieu, Lemieux \& Deprès, 2010; Rocha \& Libby, 2009; Wang \& Nakayama, 2010). More specifically, excess adipose tissue induces pro-inflammatory cytokines, including IL- 6 and TNF- $\alpha$ (Calabrò et al., 2009) which precipitate the release of CRP from the liver (Wang \& Nakayama, 2010; Yudkin, Stheouwer, Emeis \& Coppack, 1999). In this way, obesity itself promotes inflammatory process which induces endothelial dysfunction and plaque formation, thus contributing atherosclerosis and higher risk for future CVD and CVD events (McGill, McMahan, Herderick et al., 2002; Meyers \& Gokce, 2007; Ikeoka, Mader, \& Pieber, 2010).

Albeit clinical symptoms related to atherosclerosis, such as chest pain or discomfort, shortness of breath or fatigue, numbness, and blurred vision commonly are not detected in adolescents and young adults, atherosclerotic changes in the vessel wall already begin early in life, and these changes progress and predispose to the development of atherosclerotic CVD and acute CVD events in middle-aged and older adult populations (Järvisalo et al., 2002). In addition, the growing overweight and obesity in adolescents 
and young adults accelerate atherosclerotic inflammatory processes (McGill, McMahan, Herderick et al., 2002; Rocha \& Libby, 2009). Therefore, knowledge of inflammatory biomarkers in relation to adiposity in adolescents and young adults may lead to new avenues to deter atherosclerotic processes that increase the risk of atherosclerotic CVD and acute CVD events in middle and older adults.

Although dual-energy x-ray absorptiometry (DEXA), computed tomography (CT), magnetic resonance imaging (MRI), and underwater weighing are more precise and reliable measures of adiposity, these require greater cost and are not feasible in routine public health and clinical practices (Stevens et al., 2008). For these reasons, adiposity has been assessed by anthropometric measures (Body mass index [BMI], body fat percentage [BF\%], waist circumference [WC], waist to hip ratio [WHR], and waist to height ratio [WHtR]) in public health and clinical practices. BMI is the most widely used anthropometric measure and is calculated as body weight in kilograms divided by height in meters squared $\left(\mathrm{kg} / \mathrm{m}^{2}\right)$ (Cornier et al., 2011). BF\%, which can be estimated from measurement of skinfold thickness or bioelectrical impedance, is also used for assessing fat mass, or adiposity, as a proportion of total body mass (Stevens, McClain, \& Truesdale, 2008). BMI and BF\% are measures of total adiposity whereas WC, WHR, and WHtR are measures of central adiposity (Cornier et al., 2011). WC has been measured in different ways. The National Institutes of Health National Heart, Lung, and Blood Institute (HNHLB) (2000), currently recommends using an inelastic tape in a horizontal plane at the end of normal expiration in United States for the measurement of WC. The WHO (2011) recommends the use of the midpoint between the lower margin of the last palpable rib and the top of the iliac crest. WHR is the circumference of the waist divided 
by the circumference of the hip and has been used for assessing body fat distribution (Cornier et al., 2011). Hip circumference is measured at the level of the widest portion of the buttocks (Cornier et al., 2011; WHO, 2011). WHtR is the circumference of the waist divided by the height (Cornier et al., 2011).

To date, there is only one systematic review and meta-analysis addressing the obesity and CRP in various populations (Choi, Joseph, \& Pilote, 2012); however, this review only focused on the CRP as a biomarker of inflammation. It is important to evaluate other inflammatory markers, such as IL- 6 and TNF- $\alpha$ in order to better understand inflammatory processes in relation to anthropometric total and central adiposity measures. Therefore, the purpose of the systematic review was to determine the associations between anthropometric adiposity measures (BMI, WC, WHR, WHtR, and $\mathrm{BF} \%$ ) and inflammatory biomarkers (CRP, IL-6, and TNF- $\alpha$ ) in adolescents and young adults without a known diagnosis of diseases. The goal of this systematic is to provide better understanding of the evidence linking anthropometric adiposity measures with inflammatory processes in young individuals free of co-morbidities. This review may provide an insight for early intervention strategies, such as a lifestyle modification and weight loss for improving long-term outcomes of reducing inflammation as related to adiposity. Additionally, this systemic review identifies gaps in current knowledge and provides future directions for research and practice.

\section{Methods}

\section{Literature Search}

A systematic literature search was conducted to identify potentially relevant studies examining the association between anthropometric adiposity measures and 
circulating levels of CRP, IL-6, and TNF- $\alpha$ in adolescents and young adults. The electronic databases Ovid MEDLINE (from 1946 to July 03, 2013), CINAHL (from 1995 to July 05 , 2013), and SCOPUS (from 1960 to July 05, 2013) were searched. Reference lists of articles that met the inclusion criteria were searched manually for any additional studies. Search terms included Medical Subject Headings (MeSH) and keywords related to anthropometric adiposity measures ("body mass index," "waist circumference," "abdominal obesity," "abdominal adiposity," "abdominal diameter," "waist to hip ratio," "waist to height ratio," "skinfold thickness," "body fat percentage," "body fat distribution," "body composition"); inflammatory markers ("inflammation," "C-reactive protein", "interleukin-6", "tumor necrosis factor-alpha"); and "adolescent," "teen," "university student," "college student," and "young adult." Each category of variables was combined with each population using the "OR" Boolean operator. The variables and population were then combined using the "AND" Boolean operator. Literature searches were limited to the English language and human subjects. The process of the search strategy is shown in Figure 1.

\section{Inclusion and Exclusion Criteria}

Inclusion criteria were: (1) adolescents and young adults aged 13 to 40 years; (2) investigated the association between at least one anthropometric adiposity measures and CRP, IL-6, and/or TNF- $\alpha$; (3) anthropometric adiposity measured by BMI, WC, WHR, WHtR, and/or body fat percentage assessing a skinfold thickness or bioelectrical impedance ; (4) CRP, IL-6, and TNF- $\alpha$ levels measured from blood samples; (5) all types of research designs; (6) an original study; (7) no country restriction; and (8) published study in English language. Exclusion criteria were: (1) adolescent and young adults with 
diagnosed diseases and infectious diseases; (2) pregnant women; (3) adiposity measured only by DEXA or MRI; (4) a review or an editorial article; and (5) an abstract.

\section{Data Extraction and Synthesis}

This review extracted year of publication, country, participants, setting, design, study period, anthropometric measures, measures of CRP, IL- 6 and TNF- $\alpha$, results, analysis and significance of the association, and adjustment of covariates (Table 1 and Table 2). Mean, range, and proportion of age, sex, ethnicity, BMI, and sample size were reported. The statistical analyses and significance of associations or correlations between anthropometric adiposity measures and CRP, IL- 6 and TNF- $\alpha$ for each study were presented as odds ratios, correlation coefficients, and/or regression coefficients with $p$ value and $95 \%$ confidence interval if original studies were reported in this way. If the results of the studies were not reported in this way, the study findings were summarized for this review. Due to variation in growth rates, hormonal changes and pubertal stage of adolescents and young adults, the two groups were considered separately in this review.

\section{Study Quality Assessment}

Study method and quality were assessed using an evaluation checklist, which was developed by the first author based on the guidelines for assessing observational studies (Pocock et al., 2004; von Elm et al., 2007; Zaccai, 2004). This evaluation checklist included 11 questions to evaluate the main issues and potential biases related to design, sampling, setting, measurements, analyses, and peer-review of each study (Table 3 and Table 4). Each item was scored as "Yes=1," "No=0," and "Not reported=0", allowing the range of the score to be 0 to 11 . 


\section{Results}

\section{Study Selection}

As can be seen in Figure 2, a total of 4,876 studies were found from the Ovid MEDLINE, CINAHL, SCOPUS databases, and manual search of references. Of these, 264 studies were identified by title and abstract. After the removal of duplicates, 176 relevant studies remained for further detailed evaluation of the full text. Of the 176 studies, 139 studies were excluded: 61 were not relevant to the research questions; 42 studies were excluded for not meeting the criteria of age 13-40 years; 27 did not report associations or correlations between anthropometric adiposity measures and inflammatory markers; in four studies adiposity was measured by only DEXA or MRI; and in two studies participants had diagnosed diseases. In addition, two studies were excluded since dependent variables were not related to inflammatory biomarkers (CRP, IL-6, and TNF- $\alpha$ ). Three cross-sectional studies were excluded due to same data from the same study cohort were collected. Four studies were a review or editorial and two studies reported an abstract only. Lastly, one systematic review and meta-analysis was excluded (Choi, Joseph \& Pilote, 2013). Thus, 28 studies were included in this systematic review. The specific search strategies are illustrated in Figure 2.

\section{Study Characteristics}

Of 28 studies, six were conducted in United States, 17 were conducted in Australia, Egypt, Germany, Spain, Brazil, Italy, United Kingdom, Columbia, Finland, and New Zealand, and five studies were conducted in Korea, China, Philippines and India. Age of participants ranged from 13 to 39 years. The studies enrolled a total of 15,862 participants; 4,859 adolescents and 11,003 young adults. Sample size ranged from 
30 to 3,289 per study. Of the 28 studies, five studies consisted of males only (Jung et al., 2008; Vikram et al., 2006; Bo, Raspo, Morra, Isaia et al., 2004; Bo, Raspo, Morra, Cassader et al., 2004; Perez et al., 2003), four studies consisted of females only (ElWakkad et al., 2013; Serrano et al., 2010; Brydon et al., 2008; Morrison et al., 2011), and 19 studies consisted of both males and females . Of the 28 studies, nine studies reported participant's ethnicity (Huang et al., 2011; Jung et al., 2008; Khan et al., 2010; Moon et al., 2004; Petty et al., 2010; Brydon et al., 2008; Mills et al., 2008; Morrison et al., 2011; Wang, Christoffel et al., 2011).

For study design, only one out of 28 studies had a prospective design (Khan et al., 2010), whereas the other remaining 27 studies used cross sectional designs. Although the data of the two studies were from the same study cohort (McDade et al., 2009; McDade et al., 2011), this review included these two studies because the outcomes of the inflammatory biomarkers are different; One study focused on CRP only (McDade et al., 2009) and the other study examined IL-6 only (McDade et al., 2011).

Of the 28 studies, nine studies analyzed data combining both males and females (Herder et al., 2007; Khan et al., 2010; Martinez-Gomez et al., 2010; Moon et al., 2004; Hermsdorff et al., 2011; McDade et al., 2009; McDade et al., 2011; Mills et al., 2008; Orri et al., 2010). Eight studies conducted a separate analysis for males and females (Denney-Wilson et al., 2008; Huang et al., 2011; Petty et al., 2010; Wang et al., 2011; Wärnber et al., 2006; Nazmi et al., 2008; Raitakari et al., 2005; Williams et al., 2002). Two studies reported data for a combined analysis for males and females as well a separate analysis for males and females (Hermsdorff et al., 2012; Wang, Reed et al., 2011). In addition, none of the studies reflected ethnic influences or ethnic differences in 
the association between anthropometric adiposity and inflammatory biomarkers in this review. Two studies reported ethnicity, but they did not determine the association between anthropometric adiposity and inflammatory biomarkers (Khan et al., 2010; McDade et al., 2011). The association between adiposity and inflammatory biomarkers was analyzed using odds ratio, Pearson coefficient, Spearman coefficient, or regression coefficient. The detailed characteristics of each study were summarized in Table 1 and Table 2.

\section{Anthropometric Adiposity Measures}

Anthropometric adiposity was assessed by BMI, WC, WHR, WHtR, and BF. The $\mathrm{BF}(\mathrm{mm})$ or $(\%)$ was examined by sum of skinfold thickness using a skinfold caliper or by bioelectrical impedance. Of the total 28 studies, 24 studies included two or more anthropometric measures; two studies used BMI only (Khan et al., 2010; McDade et al., 2011); one study used WC only (Jung et al., 2008); and one study used BF\% only (Hermsdorff et al., 2012). Twenty six studies considered adiposity as a continuous variable and two studies analyzed adiposity as a categorical variable (Denney-Wilson et al., 2008; Nazmi et al., 2008). Of these two studies, one study categorized BMI into nonobese, overweight and obesity based on the International Obesity Task Force and the United Kingdom Child Growth Foundation Charts (Denney-Wilson et al., 2008) and the other study categorized BMI into WHO recommendation: $<18.5 \mathrm{~kg} / \mathrm{m}^{2}$ (underweight), $18.5-24.9 \mathrm{~kg} / \mathrm{m}^{2}$ (normal), $25.0-29.9 \mathrm{~kg} / \mathrm{m}^{2}$ (overweight), and $30 \mathrm{~kg} / \mathrm{m}^{2}$ (obese) (Nazmi et al., 2008) (Table 1 and Table 2). 


\section{Measurement of CRP, IL-6 and TNF- $\alpha$}

CRP was measured using diverse immunoassay tests. Five studies used enzymelinked immunosorbent assay (ELIZA), 5 studies used immune-turbidimetry, 2 studies used high-sensitivity immunoassay, 2 studies used automated DPC immulite chemiluminescent immunoassay, and other studies used ultrasensitive assay, high sensitive-monoclonal antibody assay, latex enhanced immune-turbidometry, sandwich immunoassay, high sensitivity-Denka-Seiken assay, high sensitivity-latex enhanced immune-nephelometric assay and Cardio high sensitivity-CRP assay. For IL-6, 6 studies used ELIZA, and other studies used high sensitivity-human cytokine, and high sensitivity-multiplex immunoassay. For TNF- $\alpha, 4$ studies used ELIZA. Of the 28 studies, 21 studies have an overnight fast.

\section{Study Quality Assessment}

None of the studies met all of the evaluation quality criteria. Of the 28 studies, eight studies met high quality (10 out of 11$)$; eight studies met nine out of 11 ; six studies met eight out of 11 ; five studies met seven out 11 ; and one studies met low quality (six out of 11). Of the 28 studies, 25 studies reported study designs either in method section, discussion or limitation section. Of the 28 studies, 10 studies did not specify inclusion and exclusion criteria, and only one study reported a sample size estimate (Nazmi et al., 2008). Of the 28 studies, six studies (Jung et al., 2009; Bo et al., 2004; Mills et al., 2008; Morrison et al., 2011; Orri et al., 2010; Raitakari et al., 2005) did not report how anthropometric adiposity was measured in detail and three studies (Hermsdorff et al., 2012; Hermsdorff et al., 2011; McDade et al., 2009) provided protocols and guidelines on the measurements of anthropometric adiposity in their reference section (Table 3, Table 
4). Of the 28 studies, 12 adjusted for covariates in data analysis. Covariates included age, gender, ethnicity, lipids, family income, physical activity, pubertal status, and homeostasis model assessment of insulin resistance (HOMA-IR) in adolescent studies, whereas, age, gender, smoking status, physical activity, skin color, family income, years of education were included in young adult studies.

Associations of Anthropometric Adiposity Measures with Inflammation in

\section{Adolescents}

Thirteen studies identified associations between anthropometric adiposity measures (BMI, WC, WHR, WHtR, and BF) and inflammatory biomarkers (CRP, IL-6, and TNF- $\alpha$ ) in adolescents. The descriptive values on anthropometric adiposity measures (BMI, WC, WHR, WHtR, and BF) and inflammatory biomarkers (CRP, IL-6, and TNFa) were reported in Table 1 .

Anthropometric adiposity and CRP. Of these 13 studies, 10 studies examined the association of anthropometric adiposity measures and CRP levels (Denney-Wilson et al., 2008; Huang et al., 2011; Jung et al., 2009; Khan, Rieder, Cohen, Coupey, \& Wildman, 2010; Martinez-Gomez et al., 2010; Petty et al., 2010; Serrano et al., 2010; Vikram et al., 2006; Wang, Christoffel et al., 2011; Wärnberg et al., 2006). Of the 10 studies, nine studies found significantly positive associations between one or more anthropometric adiposity measures (BMI, WC, WHR, WHtR, and BF) and CRP (Denney-Wilson et al., 2008; Huang et al., 2011; Jung et al., 2009; Khan, Rieder, Cohen, Coupey, \& Wildman, 2010; Martinez-Gomez et al., 2010; Petty et al., 2010; Vikram et al., 2006; Wang, Christoffel et al., 2011; Wärnberg et al., 2006). However, one study did not find any significant association of BMI and WC with CRP (Petty et al., 2010). Of the 
nine studies, five studies included males and females separately (Denney-Wilson et al., 2008; Huang et al., 2011; Petty et al., 2010; Wang, Christoffel et al., 2011; Wärnberg et al., 2006). Of the five studies, four studies revealed that there were significantly positive associations between two and more anthropometric adiposity measures (BMI, WC, WHtR, and BF) and CRP in both males and females (Denney-Wilson et al., 2008; Huang et al., 2011; Wang, Christoffel et al., 2011; Wärnberg et al., 2006). However, one study revealed that there were significantly positive associations of BMI and WC with CRP only for females but not males (Petty et al., 2010).

Anthropometric adiposity and IL-6. Of these 13 studies, three studies determined associations of anthropometric adiposity measures (BMI, WC, and BF) and IL-6 levels (Herder et al., 2007; Martinez-Gomez et al., 2010; Petty et al., 2010). Only one study revealed that there were significantly positive associations between anthropometric adiposity measures (BMI and WC) and IL-6 levels (Herder et al., 2007). In contrast, the remaining two studies revealed that no significant association between anthropometric adiposity measures and IL-6 (Martinez-Gomez et al., 2010; Petty et al., 2010). Of the three studies, only one study included a separate analysis for males and females (Petty et al., 2010). This study found that there were no significant associations of BMI and WC with IL-6 in males or females (Petty et al., 2010).

Anthropometric adiposity and TNF- $\alpha$. Of these 13 studies, three examined associations of anthropometric adiposity measures (BMI, WC, WHR, and BF) and TNF$\alpha$. Two studies found that there were significant positive associations of BMI, WC, and WHR with TNF- $\alpha$ (El-Wakkad et al., 2013; Moon et al., 2004). However, one study did 
not find significant associations of BMI and WC with TNF- $\alpha$ (Herder et al., 2007). None of these studies included sex differences.

\section{Association of Anthropometric Adiposity Measures and Inflammation in Young}

Adults

Fifteen studies found associations between anthropometric measures (BMI, WC, WHR, WHtR, and BF) and inflammatory biomarkers (CRP, IL-6, and TNF- $\alpha$ ) in young adults. The descriptive values on anthropometric adiposity measures (BMI, WC, WHR, WHtR, and BF) and inflammatory biomarkers (CRP, IL-6, and TNF- $\alpha$ ) were reported in Table 2.

Anthropometric adiposity and CRP. Of the 15 studies, 13 studies determined the association of anthropometric adiposity measures and CRP (Bo, Raspo, Morra, Cassader, et al., 2004; Bo, Raspo, Morra, Isaia, et al., 2004; Hermsdorff et al., 2012; Hermsdorff, Zulet, Puchau, \& Martinez, 2011; McDade et al., 2009; Mills et al., 2008; Morrison et al., 2011; Nazmi et al., 2008; Orri, Carter, \& Howington, 2010; Perez et al., 2003; Raitakari et al., 2005; Wang, Reed, Goli, \& Goswami, 2011; Williams et al., 2002). All of the 13 studies found that there were significant positive associations between one or more anthropometric adiposity measures (BMI, WC, WHR, and BF) and CRP. Of the 13 studies, five studies included a sex differences (Hermsdorff et al., 2012; Nazmi et al., 2008; Raitakari et al., 2005; Wang, Reed et al., 2011; Williams et al., 2002). Of the five studies, four found that there were significantly positive associations between two or more anthropometric adiposity measures (BMI, WC, WHR, and BF) and CRP in both males and females (Hermsdorff et al., 2012; Nazmi et al., 2008; Raitakari et al., 2005; Williams et al., 2002). However, remaining one study showed that there were significant 
positive associations of $\mathrm{BMI}$ and $\mathrm{BF} \%$ with $\mathrm{CRP}$ in females but not males (Wang, Reed et al., 2011).

Anthropometric adiposity and IL-6. Of these 15 studies, five studies focused on associations between anthropometric adiposity measures (BMI, WC, WHR, and BF\%) and IL-6. Of the five studies, four reported a significant positive associations between one or more anthropometric adiposity measures (BMI, WHR, and BF\%) and IL-6 (Brydon et al., 2008; Hermsdoff et al., 2011; McDade et al., 2011; Mills et al., 2008). However, one study did not find significant associations of BMI and BF\% with IL-6 (Wang, Reed et al., 2011). Of the five studies, sex differences were examined only in one study, in which no significant associations of BMI and BF\% with IL-6 in either males or females were found (Wang, Reed et al., 2011).

Anthropometric adiposity and TNF- $\alpha$. Of these 15 studies, only one study examined associations between anthropometric adiposity measures (BMI and BF\%) and TNF- $\alpha$ (Wang, Reed et al., 2011). The study did not find significant associations of BMI and BF\% with TNF- $\alpha$ (Wang, Reed et al., 2011). In sex differences, the study did not find significant associations of BMI and BF\% with TNF- $\alpha$ in either males or females (Wang, Reed et al., 2011).

\section{Discussion}

\section{Synthesis of Main Findings and Knowledge}

The major finding of this systematic review is that there is a significant and positive association between anthropometric adiposity measured by total and central adiposity (BMI, WC, WHtR, WHR, and BF\%) and CRP in adolescents and young adults in 22 out of 23 studies (96\%). These positive associations are consistent with the findings 
of a previous review on the positive association between abdominal adiposity and CRP in adults (Brooks et al., 2010) and a previous systematic review and meta-analysis on obesity and CRP in various populations (Choi, Joseph, \& Pilote, 2012). In addition, elevated circulating levels of CRP were found in obese participants when compared with non-obese counterparts, which supported evidence for an association of obesity and CRP (Denney-Wilson et al., 200; Nazmi et al., 2008) $(p<0.05)$. The finding of a significant association between obesity and CRP is in agreement with previous results showing that weight loss was associated with a decline in circulating levels of CRP in obese individuals aged 20 to 46 years (Esposito et al., 2003) and systematic review (Selvin, Paynter, \& Erlinger, 2007) which provide additional supportive evidence for a link of obesity and CRP. Only one study did not indicate.any significant associations between the anthropometric measures (BMI, WC, WHR, and BF\%) and CRP in female adolescents in Brazil (Serrano et al., 2010). This study did not report detailed information about the measurement of CRP assay and coefficients of variation (CV), and did not discuss any limitations regarding the findings.

The present systematic review examined additional inflammatory biomarkers, including IL-6 and TNF- $\alpha$ and anthropometric adiposity. The findings of the review in the associations between anthropometric adiposity measures (BMI, WC, WHR, and BF\%) with IL-6 from eight studies and TNF- $\alpha$ from four studies in adolescents and young adults have shown inconsistent results. Of the eight studies of IL-6, five studies revealed significant positive associations $(p<0.05)$ in adolescents (Herder et al., 2007) and young adults (Brydon et al., 2008; Hermsdoff et al., 2011; McDade et al., 2011; Mills et al., 2008), whereas three studies showed no significant associations in adolescents 
(Martinez-Gomez et al., 2010; Petty et al., 2010) and young adults (Wang, Reed et al., 2011). Of the four studies in TNF- $\alpha$, two studies revealed significantly positive associations $(p<0.05)$ in adolescents (El-Wakkad et al., 2013; Moon et al., 2004) and two studies found no significant associations in adolescents and young adults (Herder et al., 2007; Wang et al., 2011). One of the possible reasons for the discrepancy may be due to the different sampling strategies. For instance, some studies consisted primarily of non-obese participants (Herder et al., 2007; Martinez-Gomez et al., 2010; Petty et al., 2010; Wang, Reed et al., 2011, whereas other studies had a preponderance of obese participants (El-Wakkad et al., 2013; Moon et al., 2004). The latter might be better able to identify an obesity-induced inflammatory association than the former. Another possible reason for the discrepant findings may be attributable to low blood concentrations of IL- 6 and TNF- $\alpha$ if some studies have participants who are mostly from a non-obese population. Of studies showing the positive association of anthropometric measures with CRP, IL- 6 and TNF- $\alpha$ in adolescents and young adults, there was no single anthropometric adiposity measure that suggested a stronger correlation than others with CRP, IL- 6 and TNF- $\alpha$ in adolescents and young adults.

Sex

Sex has been reported to influence the association between anthropometric adiposity measures and inflammatory biomarkers. For sex differences, only two studies reported there were significant positive associations of anthropometric adiposity measures (BMI, WC, and BF\%) with CRP in female but not males (Petty et al., 2010; Wang et al., 2011). The findings are congruent with previous systematic review and meta-analysis showing that $r$ for BMI and $\ln (\mathrm{CRP})$ was greater in women than men by 
0.24 (CI, 0.09-0.37) in adults (Choi, Joseph, \& Pilote, 2012). In a previous populationbased study of middle-aged men and women, adiposity was strongly associated with higher CRP levels in women as compared to men (Thorand et al., 2006). It could be explained in several ways. First of all, women have more total adiposity and subcutaneous fat than men (Lohman, 1981). In addition, women have higher levels of CRP as compared to men (Khera et al., 2005). Moreover, women who take oral contraceptives have higher levels of CRP compared with those taking a placebo (Eilertsen et al., 2005). Furthermore, women during menses have higher levels of CRP (median, $0.74 \mathrm{mg} / \mathrm{L}$ ), than CRP during the follicular phase of the menstrual cycle and CRP during ovulation is lowest (Gaskins et al., 2011). In these cases, study designs could control use of oral contraceptives as a covariate. Also, data on CRP could be collected at times other than the menstrual phase. Thus, the associations between anthropometric adiposity measures and inflammatory biomarkers might be modified by sex. However, further studies are needed to identify sex differences while controlling use of oral contraceptives and menses. None of studies determined sex differences in anthropometric adiposity measures and IL-6 and TNF- $\alpha$.

\section{Ethnicity}

For ethnicity differences, none of the studies reflected ethnic and race differences in associations between anthropometric adiposity measures and inflammatory markers in this review. Only two studies out of 28 studies reported ethnicity, but these studies did not determine differences by ethnicity (Khan et al., 2010; Mills et al., 2008). Previous systematic review and meta-analysis found that the association $(r)$ between obesity (BMI) and $\ln (\mathrm{CRP})$ was greater in North Americans/Europeans than Asians by $0.15(\mathrm{CI}, 0-$ 
0.28), which indicated that ethnicity may be a potential moderator between anthropometric adiposity measures and inflammatory markers. Therefore, information on ethnicity should be obtained and tested as a moderating variable in the analysis of future studies.

\section{Study Methodological Quality}

The majority of studies used a cross-sectional design, from which causality between adiposity and inflammation could not be determined. Additionally, this crosssectional design does not allow a prospective evaluation of these associations. Ten studies of a total of 28 studies did not address specific inclusion and exclusion criteria of participants. Of the 10 studies, seven studies were conducted in nationally representative samples and the participants were relatively healthy adolescents and young adults (Denney-Wilson et al., 2008; Huang et al., 2011; Martinex-Gomez et al., 2010; McDade et al., 2009; Morrison et al., 2011; Nazmi et al., 2008; Wang et al., 2011); however, studies without considering inclusion and exclusion criteria had reduced internal validity. Interestingly, most studies did not report any power calculation to justify their sample size, although most of these studies included a large sample size and were populationbased studies. Studies conducted with a small sample size without achieving sufficient power also may reduce generalizability and external validity.

In addition ten of these 28 studies did not report $\mathrm{CV}$ of the assay, so the degree of measurement error is unknown. Moreover, one study addressed that CRP was measured by non-high sensitive assay, which potentially could lead to underestimation of the association of anthropometric adiposity and CRP (Williams, et al., 2002). More sensitive biomarkers should be required to accurately detect circulating levels of the inflammation 
especially in healthy populations in order to avoid reducing internal validity.

Furthermore, the majority of studies assessed a single CRP, IL- 6 and TNF- $\alpha$ measurement, which may not accurately reflect long term-low grade inflammatory status. Sixteen of the 28 studies did not report potential confounders, such as age, sex, ethnicity, acute smoking/current smokers, and alcohol dependence for their statistical analyses (O'Connor et al., 2009). This lack of identification and control of potential confounding variables also reduced internal validity.

\section{Gaps and Future Directions}

In order to further advance knowledge in the area of anthropometric adiposity measures and inflammation in adolescents and young adults, gaps are identified and recommendations are proposed based on this review. First of all, there is not enough evidence to arrive at the conclusion of anthropometric adiposity measures with IL-6 and TNF- $\alpha$. More evidence is required for anthropometric adiposity measures with IL- 6 and TNF- $\alpha$, particularly using continuous variables for more accurate estimation of the strength of associations. Also, stratified sampling or quota sampling strategies regarding non-obese, overweight, and obese participants should be considered for better detection of associations between adiposity and inflammatory processes. Secondly, of the 28 studies, ten studies included a sex breakdown and a statistical analysis was performed for males and females separately. Of the 28 studies, four studies did not control sex either separately or as a covariate (Moon et al., 2004; McDade et al., 2009; Mills et al., 2008; Orri et al., 2010), and none of the studies determined ethnicity differences or influences. Future studies should routinely obtain and assess sex and ethnicity because of the potential impact of sex and ethnicity in the association between adiposity and 
inflammation (Choi et al., 2012; O'Connor et al., 2009). Thirdly, other important variables, such as a smoking status, alcohol dependence, acute exercise, and selective serotonin reuptake inhibitor (SSRI) use, which increase in inflammatory markers and may contribute to the heterogeneous results, should be assessed, controlled and possibly excluded (O'Connor et al., 2009), and explain how and why they chose covariates for adjustment or exclusion criteria in order to rule out their effects on the association between anthropometric adiposity measures and inflammation. In addition, two studies suggested that diet and physical activity/fitness play an important role in reducing inflammatory markers (Petty et al., 2010; Vikram et al., 2006), thus future studies need to focus on the interplay of diet and physical activity/fitness, and how those variables influence the association between anthropometric adiposity measures and inflammation. Fourthly, most studies did not provide the justification of their sample size. Future studies should consider sufficient power calculation to justify their enough sample size or a larger sample of both genders in order to confirm these findings. Fifthly, since there is a limitation of cross-sectional design, the significant association between anthropometric adiposity measures and inflammation need to be evaluated in prospective studies in adolescents and young adults. Sixthly, most studies pointed out the use of a single measurement of inflammatory biomarkers, which may reduce a precision to reflect a long-term inflammatory status. Future studies should consider repeated measurements in order to ascertain a more stable estimate of inflammatory status. Lastly, in order to understand underlying inflammatory mechanisms in relation to anthropometric adiposity, other inflammatory markers, such as IL-1 $\beta$, should be investigated. 


\section{Review Limitations}

This systematic review has some limitations. First of all, since this review was limited by studies published in English language, a reporting bias may exist. Some of the included studies did not consider their inclusion and exclusion criteria, which may reduce internal validity. In addition, this review only focused on indirect measures of excess adiposity; BMI, WC, WHR, WHtR, and BF\%, which has less accuracy than direct measures, such as DEXA, CT, or MRI. Furthermore, heterogeneity of study populations and diverse statistical analyses for associations limited the consolidation for synthesis of main findings. The evaluation checklist for study quality assessment was developed based on the guidelines for assessing observational studies (Atlantis \& Baker, 2008; Pocock et al., 2004; von Elm et al., 2007; Zaccai, 2003). The quality score did not establish cutoff score to determine strong, moderate, or weak of included studies. Finally, the populations of this review only focused on adolescents and young adults therefore the findings could be different from middle and older adulthood due to physical and biological changes. In spite of these limitations, findings of this review have significant implications for assessing inflammatory biomarkers in relation to adiposity in public health and clinical practices. More importantly, although associations between obesity and CRP has been explored in a systematic review and meta-analysis in various populations (Choi et al., 2012), our review included empirical literature investigating the associations of anthropometric approach assessing adiposity measures (BMI, WC, WHR, WHtR, and BF\%) and inflammatory biomarkers, including CRP IL-6 and TNF- $\alpha$ in adolescent and young adult populations. 


\section{Conclusions}

This systematic review overall identified that there are consistently positive associations of anthropometric adiposity measures (BMI, WC, WHR, and BF\%) and CRP in adolescents and young adults without a known diagnosis of diseases. Findings of anthropometric adiposity measures (BMI, WC, WHR, and BF\%) and IL-6 and TNF- $\alpha$ in adolescents and young adults remain inconclusive. No single anthropometric adiposity measures in adolescents and young adults would appear to be superior in relation to CRP, IL-6 and TNF- $\alpha$. Further studies are needed to identify the strength and patterns of association of anthropometric adiposity measures with CRP, IL- 6 and TNF- $\alpha$. Moreover, further studies are needed to identify ethnicity differences in the association of anthropometric adiposity measures and inflammatory biomarkers. Lastly, research is needed to focus on the interplay of diet, physical activity/fitness, or weight loss with CRP, IL-6 and TNF- $\alpha$ for developing appropriate and effective lifestyle modification in reducing circulating levels of CRP, IL-6 and TNF- $\alpha$ and in preventing further development of atherosclerotic CVD and acute CVD events in later life. 


\section{References}

Adiposity. (n.d.). In Merriam-Webster's online dictionary ( $11^{\text {th }}$ ed.). Retrieved from http://www.merriam-webster.com/medical/adiposity

American College of Sports Medicine (2010). Guidelines for exercise testing and prescription (8th ed.). Philadelphia, PA: Lippincott, Williams \& Wilkins.

Bajpai, A., Goyal, A., \& Sperling, L. (2010). Should we measure C-reactive protein on earth or just on JUPITER? Clinical Cardiology, 33(4), 190-198. doi:10.1002/clc. 20681

Bo, M., Raspo, S., Morra, F., Cassader, M., Isaia, G., \& Poli, L. (2004). Body fat is the main predictor of fibrinogen levels in healthy non-obese men. Metabolism: Clinical and Experimental, 53(8), 984-988. doi: 10.1016/j.metabol.2003.12.009

Bo, M., Raspo, S., Morra, F., Isaia, G., Cassader, M., Fabris, F., \& Poli, L. (2004). Body fat and C-reactive protein levels in healthy non-obese men. Nutrition, Metabolism and Cardiovascular Diseases, 14(2), 66-72. doi:10.1016/S0939-4753(04)80012-7

Brooks, G. C., Blaha, M. J., \& Blumenthal, R. S. (2010). Relation of C-reactive protein to abdominal adiposity. The American Journal of Cardiology, 106(1), 56-61. doi:10.1016/j.amjcard.2010.02.017

Brydon, L., Wright, C. E., O'Donnell, K., Zachary, I., Wardle, J., \& Steptoe, A. (2008). Stress- induced cytokine responses and central adiposity in young women. International Journal of Obesity, 32(3), 443-450. doi:10.1038/sj.ijo.0803767

Buckley, D. I., Fu, R., Freeman, M., Rogers, K., \& Helfand, M. (2009). C-reactive protein as a risk factor for coronary heart disease: A systematic review and meta- 
analyses for the U.S. preventive services task force. Annals of Internal Medicine, $151(7), 483-495$.

Calabro, P., Golia, E., Maddaloni, V., Malvezzi, M., Casillo, B., Marotta, C., . . Golino, P. (2009). Adipose tissue-mediated inflammation: The missing link between obesity and cardiovascular disease? Internal and Emergency Medicine, 4(1), 2534. doi: $10.1007 / \mathrm{s} 11739-008-0207-2$

Choi, J., Joseph, L., \& Pilote, L. (2013). Obesity and C-reactive protein in various populations: A systematic review and meta-analysis. Obesity Reviews, 14(3), 232244. doi:10.1111/obr.12003

Cornier, M. -., Després, J. -., Davis, N., Grossniklaus, D. A., Klein, S., Lamarche, B., . . Poirier, P. (2011). Assessing adiposity: A scientific statement from the American Heart Association. Circulation, 124(18), 1996-2019. doi:10.1161/CIR.0b013e318233bc6a

de Koning, L., Merchant, A. T., Pogue, J., \& Anand, S. S. (2007). Waist circumference and waist-to-hip ratio as predictors of cardiovascular events: Meta-regression analysis of prospective studies. European Heart Journal, 28(7), 850-856. doi:10.1093/eurheartj/ehm026

Denney-Wilson, E., Hardy, L. L., Dobbins, T., Okely, A. D., \& Baur, L. A. (2008). Body mass index, waist circumference, and chronic disease risk factors in Australian adolescents. Archives of Pediatrics and Adolescent Medicine, 162(6), 566-573. doi:10.1001/archpedi.162.6.566

Eilertsen, A. L., Hoibraaten, E., Os, I., Andersen, T. O., Sandvik, L., \& Sandset, P. M. (2005). The effects of oral and transdermal hormone replacement therapy on C- 
reactive protein levels and other inflammatory markers in women with high risk of thrombosis. Maturitas,52(2), 111-118. doi: 10.1016/j.maturitas.2005.01.004

El-Wakkad, A., Hassan, N. E. M., Sibaii, H., \& El-Zayat, S. R. (2013). Proinflammatory, anti-inflammatory cytokines and adiponkines in students with central obesity. Cytokine, 61(2), 682-687.

Esposito, K., Pontillo, A., Di Palo, C., Giugliano, G., Masella, M., Marfella, R., \& Giugliano, D. (2003). Effect of weight loss and lifestyle changes on vascular inflammatory markers in obese women: A randomized trial. JAMA : The Journal of the American Medical Association, 289(14), 1799-1804. doi:

10.1001/jama.289.14.1799

Gaskins, A. J., Wilchesky, M., Mumford, S. L., Whitcomb, B. W., Browne, R. W., Wactawski-Wende, J., . . . Schisterman, E. F. (2012). Endogenous reproductive hormones and C-reactive protein across the menstrual cycle: The BioCycle study. American Journal of Epidemiology, 175(5), 423-431. doi: 10.1093/aje/kwr343

Gelber, R. P., Gaziano, J. M., Orav, E. J., Manson, J. E., Buring, J. E., \& Kurth, T. (2008). Measures of obesity and cardiovascular risk among men and women. Journal of the American College of Cardiology, 52(8), 605-615. doi:10.1016/j.jacc.2008.03.066

Go, A. S., Mozaffarian, D., Roger, V. L., Benjamin, E. J., Berry, J. D., Borden, W. B., . . American Heart Association Statistics Committee and Stroke Statistics Subcommittee. (2013). Heart disease and stroke statistics--2013 update: A report from the american heart association. Circulation, 127(1), e6-e245. doi: 10.1161/CIR.0b013e31828124ad; 10.1161/CIR.0b013e31828124ad 
Herder, C., Schneitler, S., Rathmann, W., Haastert, B., Schneitler, H., Winkler, H., . . . Martin, S. (2007). Low-grade inflammation, obesity, and insulin resistance in adolescents. Journal of Clinical Endocrinology and Metabolism, 92(12), 45694574.

Hermsdorff, H. H., Volp, A. C., Puchau, B., Barbosa, K. B., Zulet, M. A., Bressan, J., \& Martinez, J. A. (2012). Contribution of gender and body fat distribution to inflammatory marker concentrations in apparently healthy young adults. Inflammation Research, 61(5), 427-435.

Hermsdorff, H. H. M., Zulet, M. Á., Puchau, B., \& Martínez, J. A. (2011). Central adiposity rather than total adiposity measurements are specifically involved in the inflammatory status from healthy young adults. Inflammation, 34(3), 161-170. doi: $10.1007 / \mathrm{s} 10753-010-9219-\mathrm{y}$

Huang, R., De Klerk, N., Mori, T. A., Newnham, J. P., Stanley, F. J., Landau, L. I., . . . Beilin, L. J. (2011). Differential relationships between anthropometry measures and cardiovascular risk factors in boys and girls. International Journal of Pediatric Obesity, 6(2 -2), e271-e282. doi: 10.3109/17477166.2010.512388

Ikeoka, D., Mader, J. K., \& Pieber, T. R. (2010). Adipose tissue, inflammation and cardiovascular disease. Revista Da Associacao Medica Brasileira (1992), 56(1), $116-121$.

Järvisalo, M. J., Harmoinen, A., Hakanen, M., Paakkunainen, U., Viikari, J., Hartiala, J., . Raitakari, O. T. (2002). Elevated serum C-reactive protein levels and early arterial changes in healthy children. Arteriosclerosis, Thrombosis, and Vascular Biology, 22(8), 1323-1328. doi: 10.1161/01.ATV.0000024222.06463.21 
Jung, C., Fischer, N., Fritzenwanger, M., Pernow, J., Brehm, B. R., \& Figulla, H. R. (2009). Association of waist circumference, traditional cardiovascular risk factors, and stromal-derived factor-1 in adolescents. Pediatric Diabetes, 10(5), 329-335. doi: $10.1111 / \mathrm{j} .1399-5448.2008 .00486 . \mathrm{x}$

Khan, U. I., Rieder, J., Cohen, H. W., Coupey, S. M., \& Wildman, R. P. (2010). Effect of modest changes in BMI on cardiovascular disease risk markers in severely obese, minority adolescents. Obesity Research and Clinical Practice, 4(3), e231-e237: http://dx.doi.org.www5.sph.uth.tmc.edu:2048/10.1016/j.orcp.2010.03.001

Khera, A., McGuire, D. K., Murphy, S. A., Stanek, H. G., Das, S. R., Vongpatanasin, W., ... de Lemos, J. A. (2005). Race and gender differences in C-reactive protein levels. Journal of the American College of Cardiology, 46(3), 464-469. doi: $10.1016 / \mathrm{j} . j a c c .2005 .04 .051$

Lear, S. A., James, P. T., Ko, G. T., \& Kumanyika, S. (2010). Appropriateness of waist circumference and waist-to-hip ratio cutoffs for different ethnic groups. European Journal of Clinical Nutrition, 64(1), 42-61. doi: 10.1038/ejcn.2009.70

Libby, P., Ridker, P. M., \& Hansson, G. K. (2009). Inflammation in atherosclerosis: From pathophysiology to practice. Journal of the American College of Cardiology, 54(23), 2129-2138. doi:10.1016/j.jacc.2009.09.009

Lobstein, T., Baur, L., Uauy, R. for the IASO International Obesity TaskForce. (2004). Obesity in children and young people: A crisis in public health. Obesity Reviews: An Official Journal of the International Association for the Study of Obesity, 5 Suppl 1, 4-104. doi: 10.1111/j.1467-789X.2004.00133.x 
Lohman, T. G. (1981). Skinfolds and body density and their relation to body fatness: A review. Human Biology, 53(2), 181-225.

Mathieu, P., Lemieux, I., \& Després, J. -. (2010). Obesity, inflammation, and cardiovascular risk. Clinical Pharmacology and Therapeutics, 87(4), 407-416. doi: $10.1038 /$ clpt.2009.311

Martinez-Gomez, D., Eisenmann, J. C., Wärnberg, J., Gomez-Martinez, S., Veses, A., Veiga, O. L., \& Marcos, A. (2010). Associations of physical activity, cardiorespiratory fitness and fatness with low-grade inflammation in adolescents: The AFINOS study. International Journal of Obesity, 34(10), 1501-1507. doi:10.1038/ijo.2010.114

McGill, H. C.,Jr, McMahan, C. A., Herderick, E. E., Zieske, A. W., Malcom, G. T., Tracy, R. E., ... Pathobiological Determinants of Atherosclerosis in Youth (PDAY) Research Group. (2002). Obesity accelerates the progression of coronary atherosclerosis in young men. Circulation, 105(23), 2712-2718.

McDade, T. W., Rutherford, J. N., Adair, L., \& Kuzawa, C. (2009). Population differences in associations between C-reactive protein concentration and adiposity: Comparison of young adults in the Philippines and the United States. American Journal of Clinical Nutrition, 89(4), 1237-1245. doi:

$10.3945 /$ ajen.2008.27080

McDade, T. W., Tallman, P. S., Adair, L. S., Borja, J., \& Kuzawa, C. W. (2011). Comparative insights into the regulation of inflammation: Levels and predictors of interleukin 6 and interleukin 10 in young adults in the Philippines. American Journal of Physical Anthropology, 146(3), 373-384. doi: 10.1002/ajpa.21586 
Meyers, M. R., \& Gokce, N. (2007). Endothelial dysfunction in obesity: Etiological role in atherosclerosis. Current Opinion in Endocrinology, Diabetes, and Obesity, 14(5), 365-369. doi: 10.1097/MED.0b013e3282be90a8

Mills, P. J., Shapiro, D., Goldstein, I. B., Ottaviani, C., Pung, M. A., Khandrika, S., . . . Rutledge, T. R. (2008). Metabolic predictors of inflammation, adhesion, and coagulability in healthy younger-aged adults. Obesity, 16(12), 2702-2706. doi: $10.1038 /$ oby.2008.420

Moon, Y. S., Kim, D. H., \& Song, D. K. (2004). Serum tumor necrosis factor-alpha levels and components of the metabolic syndrome in obese adolescents.

Metabolism: Clinical \& Experimental, 53(7), 863-867. doi: 10.1016/j.metabol.2004.02.007

Morrison, J. A., Glueck, C. J., Daniels, S. R., Wang, P., Stroop, D. M., \& Horn, P. S. (2011). High-sensitivity $\mathrm{C}$ reactive protein: Associations with cardiovascular risk factors and tracking in female adolescents and young adults. Isrn Pediatrics Print, 2011, 707206. doi:10.5402/2011/707206

National Institutes of Health National Heart, Lung, and Blood Institute (2000). The practical guide, Identification, evaluation, and treatment of overweight and obesity in adults. Retrieved from www.nhlbi.nih.gov/guidelines/obesity/prctgd_c.pdf

Nazmi, A., Oliveira, I. O., \& Victora, C. G. (2008). Correlates of C-reactive protein levels in young adults: A population-based cohort study of 3827 subjects in Brazil. Brazilian Journal of Medical and Biological Research, 41(5), 357-367. 
Retrieved from http://www.scielo.br/scielo.php?script=sci_pdf\&pid=S0100879X2008000500003\&lng=en\&nrm=iso\&tlng=en

O'Connor, M. F., Bower, J. E., Cho, H. J., Creswell, J. D., Dimitrov, S., Hamby, M. E., . . . Irwin, M. R. (2009). To assess, to control, to exclude: Effects of biobehavioral factors on circulating inflammatory markers. Brain, Behavior, \& Immunity, 23(7), 887-897: http://dx.doi.org/10.1016/j.bbi.2009.04.005

Orri, J. C., Carter, S. R., \& Howington, E. B. (2010). Gender comparison of C-reactive protein and cardiovascular disease risk in college students and intercollegiate athletes. Journal of Sports Medicine and Physical Fitness, 50(1), $72-78$.

Packard, R. R., \& Libby, P. (2008). Inflammation in atherosclerosis: From vascular biology to biomarker discovery and risk prediction. Clinical Chemistry, 54(1), 2438. doi: $10.1373 /$ clinchem. 2007.097360

Perez, M., Casas, J. P., Cubillos-Garzón, L. A., Serrano, N. C., Silva, F., Morillo, C. A., \& López-Jaramillo, P. (2003). Using waist circumference as a screening tool to identify Colombian subjects at cardiovascular risk. European Journal of Cardiovascular Prevention and Rehabilitation, 10(5), 328-335. doi:10.1097/01.hjr.0000095050.46631.6f

Petersen, A. M., \& Pedersen, B. K. (2005). The anti-inflammatory effect of exercise. Journal of Applied Physiology, 98(4), 1154-1162. doi:10.1152/japplphysiol.00164.2004

Petty, K. H., Li, K., Dong, Y., Fortenberry, J., Stallmann-Jorgensen, I., Guo, D., \& Zhu, H. (2010). Sex dimorphisms in inflammatory markers and adiposity in African- 
American youth. International Journal of Pediatric Obesity, 5(4), 327-333. doi: $10.3109 / 17477160903497019$

Pocock, S. J., Collier, T. J., Dandreo, K. J., de Stavola, B. L., Goldman, M. B., Kalish, L. A., ... McCormack, V. A. (2004). Issues in the reporting of epidemiological studies: A survey of recent practice. BMJ (Clinical Research Ed.), 329(7471), 883. doi:10.1136/bmj.38250.571088.55

Raitakari, M., Mansikkaniemi, K., Marniemi, J., Viikari, J., \& Raitakari, O. T. (2005). Distribution and determinants of serum high-sensitive C-reactive protein in a population of young adults. the cardiovascular risk in young Finns study. Journal of Internal Medicine, 258(5), 428-434. doi: 10.1111/j.1365-2796.2005.01563.x

Rocha, V. Z., \& Libby, P. (2009). Obesity, inflammation, and atherosclerosis. Nature Reviews. Cardiology, 6(6), 399-409. doi:10.1038/nrcardio.2009.55

Schuett, H., Luchtefeld, M., Grothusen, C., Grote, K., \& Schieffer, B. (2009). How much is too much? interleukin-6 and its signaling in atherosclerosis. Thrombosis and Haemostasis, 102(2), 215-222. doi:10.1160/TH09-05-0297

Selvin, E., Paynter, N. P., \& Erlinger, T. P. (2007). The effect of weight loss on Creactive protein: A systematic review. Archives of Internal Medicine, 167(1), 3139. doi: $10.1001 /$ archinte.167.1.31

Serrano, H. M. S., Carvalho, G. Q., Pereira, P. F., Do Carmo Gouveia Peluzio, M., Do Carmo Castro Franceschini, S., \& Priore, S. E. (2010). Body composition, biochemical and clinical changes of adolescents with excessive adiposity. [Composição corpórea, alterações bioquímicas e clínicas de adolescentes com 
excesso de adiposidade] Arquivos Brasileiros De Cardiologia, 95(4), 464-472: http://dx.doi.org/10.1590/S0066-782X2010005000109

Stevens, J., McClain, J. E., \& Truesdale, K. P. (2008). Selection of measures in epidemiologic studies of the consequences of obesity. International Journal of Obesity (2005), 32 Suppl 3, S60-6. doi:10.1038/ijo.2008.88

Thorand, B., Baumert, J., Doring, A., Herder, C., Kolb, H., Rathmann, W., . . KORA Group. (2006). Sex differences in the relation of body composition to markers of inflammation. Atherosclerosis, 184(1), 216-224.

doi:10.1016/j.atherosclerosis.2005.04.011

von Elm, E., Altman, D. G., Egger, M., Pocock, S. J., GÃ ,tzsche, P. C., \& Vandenbroucke, J. P. (2007). The strengthening the reporting of observational studies in epidemiology (STROBE) statement: Guidelines for reporting observational studies*. Bulletin of the World Health Organization, 85(11), 867872. doi:10.2471/BLT.07.045120

Vikram, N. K., Misra, A., Pandey, R. M., Dwivedi, M., Luthra, K., Dhingra, V., \& Talwar, K. K. (2006). Association between subclinical inflammation \& fasting insulin in urban young adult north Indian males. Indian Journal of Medical Research, 124(DEC.), 677-682.

Wang, G., Christoffel, K. K., Brickman, W. J., Hong, X., Arguelles, L., Zhang, S., . . . Wang, X. (2011). C-reactive protein in adolescent twins: Patterns and relationship to adiposity. Journal of Clinical Endocrinology and Metabolism, 96(10), 32263233. doi:10.1210/jc.2011-0590 
Wang, S., Reed, D. B., Goli, S., \& Goswami, D. (2011). Blood leptin and C-reactive protein provide more sensitive assessment than blood lipids and other inflammatory biomarkers in overweight university students. Nutrition Research, 31(8), 586-593. doi: 10.1016/j.nutres.2011.07.006

Wang, Z., \& Nakayama, T. (2010). Inflammation, a link between obesity and cardiovascular disease. Mediators of Inflammation, 2010, 535918. doi:10.1155/2010/535918

Wärnberg, J., Nova, E., Moreno, L. A., Romeo, J., Mesana, M. I., Ruiz, J. R., . . Blay, M. G. (2006). Inflammatory proteins are related to total and abdominal adiposity in a healthy adolescent population: The AVENA study. American Journal of Clinical Nutrition, 84(3), 505-512.

WHO (2000). Obesity: Preventing and managing the global epidemic. Report of a WHO consultation. World Health Organization Technical Report Series, 894, i-xii, 1253.

WHO (1995). Physical status: The use and interpretation of anthropometry report of a WHO expert committee. World Health Organization Technical Report Series, $854,1-452$.

Widlansky, M. E., Gokce, N., Keaney, J. F.,Jr, \& Vita, J. A. (2003). The clinical implications of endothelial dysfunction. Journal of the American College of Cardiology, 42(7), 1149-1160. doi: 10.1016/S0735-1097(03)00994-X

Williams, M. J., Poulton, R., \& Williams, S. (2002). Relationship of serum ferritin with cardiovascular risk factors and inflammation in young men and women. Atherosclerosis, 165(1), 179-184. doi: 10.1016/S0021-9150(02)00233-2 
Wilson, A. M., Ryan, M. C., \& Boyle, A. J. (2006). The novel role of C-reactive protein in cardiovascular disease: Risk marker or pathogen. International Journal of Cardiology, 106(3), 291-297. doi: 10.1016/j.ijcard.2005.01.068

World Health Organization (2012). Obesity and overweight. Retrieved from http://www.who.int/mediacentre/factsheets/fs311/en/

World Health Organization (2011). Waist circumference and waist- hip ratio. Report of a WHO Expert Consultation, Geneva, 8-11 December 2008 Retrieved from http://www.who.int/nutrition/publications/obesity/WHO_report_waistcircumferen ce_and_waisthip_ratio/en/

Yudkin, J. S., Stehouwer, C. D., Emeis, J. J., \& Coppack, S. W. (1999). C-reactive protein in healthy subjects: Associations with obesity, insulin resistance, and endothelial dysfunction: A potential role for cytokines originating from adipose tissue? Arteriosclerosis, Thrombosis, and Vascular Biology, 19(4), 972-978. doi: 10.1161/01.ATV.19.4.972

Zaccai, J. (2004). How to assess epidemiological studies. Postgraduate Medical Journal, 80(941), 140-147. doi:10.1136/pgmj.2003.012633 


\section{Ovid Medline search}

(1946 to July 032013 )

1. exp Inflammation/

2. exp cytokines/ or exp interleukin-6/ or exp tumor necrosis factor-alpha/

3. exp C-Reactive Protein/

4. (crp or c-reactive or interleukin 6 or il-6 or tnf-alpha or tnf).ti,ab.

5. 1 or 2 or 3 or 4

6. exp adolescent/ or exp young adult/

7. exp young adult/

8. (aged adj2 ("24" or "25" or "26" or "27" or "28" or "29" or "30" or "31" or "32" or "33" or "34" or "35" or "36" or "37" or "38" or "39" or "40")).ab.

9. (youth or adolescen* or teen* or young adult* or university student*).ti,ab.

10.6 or 7 or 8 or 9

11. body mass index/ or (body mass or bmi).ti,ab.

12. skinfold thickness/ or skinfold*.ti,ab.

13. body fat distribution/or adiposity/

14. body fat percentage.ti,ab. or body composition/

15. (anthropometric adiposity or anthropometric measure*).ti,ab.

16. waist to heihgt ratio/ or waist to height ratio.ti,ab.

17. waist circumference/ or abdominal obesity/ or abdominal adiposity.ti,ab. or abdominal diameter.ti,ab.

18. waist to hip ratio/ or waist to hip ratio.ti,ab.

19. 5 and 10 
20.11 or 12 or 13 or 14 or 15 or 16 or 17 or 18

21. 19 and 20

22. limit 21 to English language

2,325 articles

\section{CINAHL search}

(1995 to July 05,2013$)$

S1. ((MH "Inflammation") OR (MH "Cytokines") OR (MH "Tumor Necrosis Factor") OR (MH "C-Reactive Protein") ) OR TI ( crp or c-reactive or interleukin 6 or tnf or il-6) OR AB ( crp or c-reactive or interleukin 6 or tnf or il-6 )

S2. ( (MH "Adolescence") OR (MH "Young Adult") ) OR TI (youth or adolescen* or teen* or young adult*) OR AB ( youth or adolescen* or teen* or young adult*)

S3. S1 and S2

S4. ((MH "Waist-Hip Ratio") OR (MH "Waist Circumference")) OR TI (adominal adiposity or abdominal diameter) $\mathrm{OR} \mathrm{AB}$ ( adominal adiposity or abdominal diameter) S5. (MH "body mass index") OR TI (body mass or bmi) OR AB (body mass or bmi) S6. (MH "Skinfold Thickness") OR TI skinfold* OR AB skinfold* S7. (MH "Adipose Tissue Distribution") OR (MH "Adipose Tissue")

S8. TI "waist to height ratio" $O R A B$ "waist to height ratio" S9. (MH "Body Composition+") OR TI body fat percentage OR AB body fat percentage $\mathrm{S} 10 . \mathrm{s} 4$ or $\mathrm{s} 5$ or $\mathrm{s} 6$ or $\mathrm{s} 7$ or $\mathrm{s} 8$ or $\mathrm{s} 9$

S11.s3 and s10

441 articles 


\section{SCOPUS search}

(1960 to July 05,2013$)$

TITLE-ABS-KEY("inflammation" OR "c-reactive protein" OR "CRP" OR "interleukin6" OR "IL-6" OR "tumor necrosis factor-alpha" OR "TNF-alpha") AND TITLE-ABSKEY("body mass index" OR " BMI" OR "skinfold thickness" OR "body fat distribution" OR "adiposity" OR "body fat percentage" OR "waist circumference" OR "waist to hip ratio" OR "waist to height ratio" OR "abdominal obesity" OR "abdominal adiposity") AND TITLE-ABS-KEY("adolescent*" OR "university student*" OR "college student*" OR "young adult*") AND (LIMIT-TO(LANGUAGE, "English"))

2,108 articles

Figure 1. Database search strategy 
Total $(=4,876)$

Ovid MEDLINE $(\mathrm{N}=2,325)$

CINAHL $(\mathrm{N}=441)$

SCOPUS $(\mathrm{N}=2,108)$

Manual search of references $(N=2)$

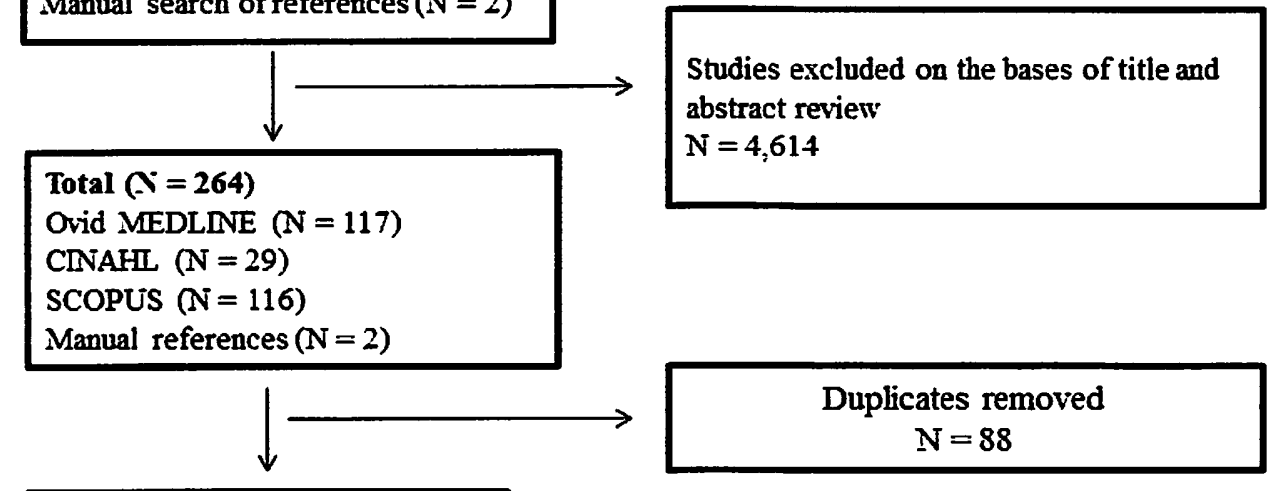

Full text studies evaluated in detail for eligibility $(x=176$

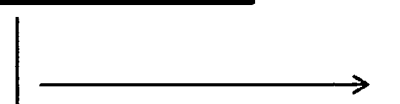

Excluded Full text studies $(\boldsymbol{N}=148)$

Not relevant $(\mathrm{N}=61)$

Did not meet age ( $13-40$ years) $(\mathrm{N}=42)$

No data of association or correlation $(\mathrm{N}=27)$

Adiposity measured by DEXA or MRI $(\mathrm{N}=4)$

Participants with diagnosed diseases $(\mathrm{N}=2)$

No dependent data of inflammatory marker(s) $(\mathrm{N}=2)$

Data from the same study cohort $(\mathrm{N}=3)$

Full text studies included in review $(\mathbf{N}=\mathbf{2 8})$

Review $(\mathrm{N}=4)$ and systematic review $(\mathrm{N}=1)$

No full-length studies; Abstract only $(\mathrm{N}=2)$

Figure 2. Flowchart of study selection for systematic review 
Table 1

Studies reporting the association of anthropometric adiposity and inflammatory biomarkers in adolescents

\begin{tabular}{|c|c|c|c|c|c|c|c|c|c|}
\hline $\begin{array}{l}\text { Author, } \\
\text { year, } \\
\text { country }\end{array}$ & Purpose & $\begin{array}{l}\text { Participants } \\
\text { (N/sex/age/adiposity/ } 1 \\
\text { markers: mean } \pm S D \text {, } \\
\text { setting/location }\end{array}$ & ammatory & $\begin{array}{l}\text { Design, } \\
\text { study } \\
\text { period }\end{array}$ & $\begin{array}{l}\text { Anthropometric } \\
\text { adiposity } \\
\text { measures } \\
\text { (BMI, WC, } \\
\text { WHR, WHtR, } \\
\text { BF\%) }\end{array}$ & $\begin{array}{l}\text { Inflammatory } \\
\text { markers } \\
\text { (CRP, IL-6, TNF- } \alpha \text { ) } \\
\text { measurement site, } \\
\text { assay, CV }\end{array}$ & Results & Analysis and significance & $\begin{array}{l}\text { Adjustments } \\
\text { for } \\
\text { covariates }\end{array}$ \\
\hline $\begin{array}{l}\text { Denney- } \\
\text { Wilson et } \\
\text { al, 2008, } \\
\text { Australia }\end{array}$ & $\begin{array}{l}\text { To determine } \\
\text { the association } \\
\text { between } \\
\text { measures of } \\
\text { adiposity (BMI, } \\
\text { WC) and risk } \\
\text { factors for heart } \\
\text { disease, type2 } \\
\text { diabetes, fatty } \\
\text { liver disease, } \\
\text { and the } \\
\text { clustering of risk } \\
\text { factors in } \\
\text { Australian } \\
\text { adolescents. }\end{array}$ & $\begin{array}{l}\mathrm{N}=496 \\
(\mathrm{M} / \mathrm{F}=290 / 206) \\
\text { Age } 15.4 \pm 0.4 \mathrm{y} \\
\\
\text { BMI (M) } \\
21.4 \pm 4.1 \\
\text { WC (M) } \\
71.9 \pm 9.6 \mathrm{~cm} \\
\mathrm{Hs}-\mathrm{CRP}(\mathrm{M})(\text { median } \\
(\mathrm{IQR})): 0.4(0.2-1.0) \\
\text { mg/L } \\
\\
\text { BMI (F) } \\
21.5 \pm 3.4 \\
\text { WC (F) } \\
65.8 \pm 7.9 \mathrm{~cm} \\
\mathrm{Hs}-\mathrm{CRP}(\mathrm{F})(\text { median } \\
(\mathrm{IQR})): 0.3(0.2-1.0) \\
\text { mg/L }\end{array}$ & $\begin{array}{l}\text { Secondary } \\
\text { schools in } \\
\text { Sydney }\end{array}$ & $\begin{array}{l}\text { Cross- } \\
\text { sectional } \\
\text { Feb 2004- } \\
\text { May 2004 } \\
\text { Substudy } \\
\text { of the } \\
\text { New } \\
\text { South } \\
\text { Wales } \\
\text { Schools } \\
\text { Physical } \\
\text { Activity } \\
\text { and } \\
\text { Nutrition } \\
\text { Survey } \\
\text { (SPANS } \\
\text { 2004) }\end{array}$ & $\begin{array}{l}\text { BMI }\left(\mathrm{kg} / \mathrm{m}^{2}\right) \\
\text { non- } \\
\text { overweight vs. } \\
\text { overweight ( } \geq \\
25) \text { vs. } \\
\text { obese }(\geq 30) \\
\text { (International } \\
\text { Obesity Task } \\
\text { Force } \\
\text { Definition cut } \\
\text { points) } \\
\text { WC (cm) } \\
\text { non- } \\
\text { overweight } \\
\text { vs. } \\
\text { overweight } \\
\text { (91 } \\
\text { percentile) vs. } \\
\text { obese ( } 95^{\text {th }} \\
\text { percentile) (UK } \\
\text { Child } \\
\text { Growth } \\
\text { Foundation } \\
\text { Charts } 1997 \text { cut } \\
\text { points) } \\
\text { : measured at } \\
\text { the narrowest } \\
\text { point between } \\
\end{array}$ & $\begin{array}{l}\text { Hs-CRP (mg/L) } \\
\text { Plasma } \\
\text { Ultrasensitive } \\
\text { assay } \\
\text { Intra-assay CV } \\
=\text { Not reported } \\
\text { Inter-assay CV } \\
=7.4 \% \\
\text { Cut-off level = } \\
3.0 \mathrm{mg} / \mathrm{L} \\
>3.0 \text { (high) } \\
\leq 3.0 \text { (low or } \\
\text { normal) } \\
\text { Overnight fast }\end{array}$ & $\begin{array}{l}\text { Hs-CRP was } \\
\text { significantly } \\
\text { associated with } \\
\text { overweight and } \\
\text { obese (defined by } \\
\text { BMI and WC) in } \\
\text { both adolescent's } \\
\text { boys and girls } \\
(p<0.001) \text {. }\end{array}$ & $\begin{array}{c}\text { Logistic regression } \\
\text { OR }(95 \% \mathrm{CI}) \\
\text { BMI }(\mathrm{M}) \\
\text { Non-overweight } \\
1(\text { ref }(\mathrm{N}=210) \\
\text { Overweight }(\mathrm{N}=61) \\
4.7(1.2-18.5) \\
\text { Obese }(\mathrm{N}=19) \\
16.6(3.5-79.2) \\
\text { wC }(\mathrm{M}) \\
\text { Non-0verweight } \\
1(\text { ref }) \quad(\mathrm{N}=232) \\
\text { Overweight }(\mathrm{N}=29) \\
3.0(0.6-15.6) \\
\text { Obese }(\mathrm{N}=29) \\
12.7(5.0-31.9) \\
\\
\text { BMI }(\mathrm{F}) \\
\text { Non-overweight } \\
1(\text { ref }(\mathrm{N}=166) \\
\text { Overweight }(\mathrm{N}=31) \\
6.8(2.4-19.0) \\
\text { Obese }(\mathrm{N}=9) \\
6.8(1.7-27.3) \\
\text { WC }(\mathrm{F}) \\
\text { Non-overweight } \\
1(\mathrm{ref})(\mathrm{N}=169) \\
\text { Overweight }(\mathrm{N}=20) \\
3.2(1.1-9.4) \\
\end{array}$ & No \\
\hline
\end{tabular}




\begin{tabular}{|c|c|c|c|c|c|c|c|c|c|}
\hline \multirow[t]{2}{*}{$\begin{array}{l}\text { Author, } \\
\text { year, } \\
\text { country }\end{array}$} & \multirow[t]{2}{*}{ Purpose } & \multicolumn{2}{|c|}{$\begin{array}{l}\text { Participants } \\
\text { (N/sex/age/adiposity/inflammatory } \\
\text { markers: mean } \pm \mathrm{SD} \text { ), } \\
\text { setting/location }\end{array}$} & \multirow[t]{2}{*}{$\begin{array}{l}\text { Design, } \\
\text { study } \\
\text { period }\end{array}$} & \multirow{2}{*}{$\begin{array}{l}\text { Anthropometric } \\
\text { adiposity } \\
\text { measures } \\
\text { (BMI, WC, } \\
\text { WHR, WHtR, } \\
\text { BF\%) } \\
\text { the lower } \\
\text { costal border } \\
\text { and the iliac } \\
\text { crest }\end{array}$} & \multirow[t]{2}{*}{$\begin{array}{l}\text { Inflammatory } \\
\text { markers } \\
\text { (CRP, IL-6, TNF- } \alpha \text { ) } \\
\text { measurement site, } \\
\text { assay, CV }\end{array}$} & \multirow[t]{2}{*}{ Results } & \multirow[t]{2}{*}{ Analysis and significance } & \multirow[t]{2}{*}{$\begin{array}{l}\text { Adjustments } \\
\text { for } \\
\text { covariates }\end{array}$} \\
\hline & & & & & & & & & \\
\hline $\begin{array}{l}\text { El- } \\
\text { Wakkad, } \\
\text { et al., } \\
2013 \text {, } \\
\text { Egypt }\end{array}$ & $\begin{array}{l}\text { To investigate } \\
\text { the effect of } \\
\text { central obesity } \\
\text { in obese } \\
\text { adolescent girls } \\
\text { on the } \\
\text { promotion of the } \\
\text { secretion of pro- } \\
\text { inflammatory } \\
\text { (TNF- } \alpha \text {, IL-1 } \beta \text {, } \\
\text { leptin) and anti- } \\
\text { inflammatory } \\
\text { adiponectin (IL- } \\
4, \text { IL-5) } \\
\text { adiponkines in } \\
\text { adolescent } \\
\text { Egyptian girls. }\end{array}$ & $\begin{array}{l}\mathrm{N}=86(\mathrm{~F}) \\
\text { Age } 13-18 \mathrm{y} \\
\text { BMI }>95 \text { percentile } \\
\text { Group I }(\mathrm{N}=43) \\
\text { (WHR }<0.80) \\
\text { WHR: mean } \pm \mathrm{SE} \\
0.74 \pm 0.00045 \\
\text { TNF- } \alpha \text { : mean } \pm \mathrm{SE} \\
2.24 \pm 0.59 \mathrm{pg} / \mathrm{ml} \\
\\
\text { Group II }(\mathrm{N}=43) \\
(W H R \geq 0.80) \\
\text { WHR: mean } \pm \mathrm{SE} \\
0.89 \pm 0.017 \\
\text { TNF- } \alpha: \text { mean } \pm \mathrm{SE} \\
30.4 \pm 1.735 \mathrm{pg} / \mathrm{ml}\end{array}$ & $\begin{array}{l}\text { Students } \\
\text { from four } \\
\text { local public } \\
\text { schools } \\
\text { Cairo in } \\
\text { Egypt }\end{array}$ & $\begin{array}{l}\text { Cross- } \\
\text { sectional } \\
\text { (Study } \\
\text { design: } \\
\text { not } \\
\text { reported) } \\
\text { Study } \\
\text { period: } \\
\text { not } \\
\text { reported }\end{array}$ & $\begin{array}{l}\text { WHR: calculated } \\
\text { by dividing WC } \\
\text { (cm) by hip } \\
\text { circumference } \\
\text { (cm). } \\
\text { WC (cm): } \\
\text { measured the } \\
\text { smaller } \\
\text { circumference } \\
\text { between the iliac } \\
\text { crest and first } \\
\text { rib. } \\
\text { Hip (cm): } \\
\text { measured at the } \\
\text { most prominent } \\
\text { area of the } \\
\text { buttocks at the } \\
\text { level of the } \\
\text { symphysis pubis. } \\
\text { Abdominal } \\
\text { obesity: WHR } \geq \\
0.80\end{array}$ & $\begin{array}{l}\text { TNF- } \alpha(\mathrm{pg} / \mathrm{mL}) \\
\text { Serum } \\
\text { ELISA } \\
\text { CV }=\text { Not reported } \\
\text { Sensitivity }=2.3 \\
\text { pg/mL } \\
\text { Fasting not } \\
\text { reported }\end{array}$ & $\begin{array}{l}\text { There was a } \\
\text { significant positive } \\
\text { correlation } \\
\text { between WHR and } \\
\text { TNF- } \alpha \text { of group II. }\end{array}$ & $\begin{array}{l}\text { Pearson correlation } \\
\text { TNF- } \alpha \\
\text { WHR }(\geq 0.80): r= \\
0.559, p<0.001 \text { in } \\
\text { group II }\end{array}$ & No \\
\hline
\end{tabular}




\begin{tabular}{|c|c|c|c|c|c|c|c|c|c|}
\hline $\begin{array}{l}\text { Author, } \\
\text { year, } \\
\text { country }\end{array}$ & Purpose & $\begin{array}{l}\text { Participants } \\
\text { (N/sex/age/adiposity/ir } \\
\text { markers: mean } \pm \text { SD), } \\
\text { setting/location }\end{array}$ & lammatory & $\begin{array}{l}\text { Design, } \\
\text { study } \\
\text { period }\end{array}$ & $\begin{array}{l}\text { Anthropometric } \\
\text { adiposity } \\
\text { measures } \\
\text { (BMI, WC, } \\
\text { WHR, WHtR, } \\
\text { BF\%) }\end{array}$ & $\begin{array}{l}\text { Inflammatory } \\
\text { markers } \\
\text { (CRP, IL-6, TNF-a) } \\
\text { measurement site, } \\
\text { assay, CV }\end{array}$ & Results & Analysis and significance & $\begin{array}{l}\text { Adjustments } \\
\text { for } \\
\text { covariates }\end{array}$ \\
\hline $\begin{array}{l}\text { Herder et } \\
\text { al, 2007, } \\
\text { Germany }\end{array}$ & $\begin{array}{l}\text { To characterize } \\
\text { the pattern of } \\
\text { subclinical } \\
\text { immune } \\
\text { activation that is } \\
\text { associated with } \\
\text { indices of } \\
\text { obesity and } \\
\text { insulin } \\
\text { resistance in } \\
\text { youth and } \\
\text { analyze whether } \\
\text { this association } \\
\text { is explained by } \\
\text { obesity as } \\
\text { assessed by BMI } \\
\text { and WC in } \\
\text { adolescents. }\end{array}$ & $\begin{array}{l}\mathrm{N}=519 \\
(\mathrm{M} / \mathrm{F}=293 / 226) \\
\text { Age } 15.5 \pm 0.8 \mathrm{y} \\
\text { BMI }(\mathrm{M}) \\
22.4 \pm 4.3 \\
\text { WC }(\mathrm{M}) \\
78.2 \pm 11.8 \mathrm{~cm} \\
\text { IL-6 (M): median } \\
(\text { IQR) } \\
0.9(0.6 ; 1.5) \mathrm{pg} / \mathrm{mL} \\
\text { TNF- } \alpha(\mathrm{M}):): \text { median } \\
(\mathrm{IQR}): \\
1.8(1.5 ; 2.2) \mathrm{pg} / \mathrm{mL} \\
\\
\text { BMI }(\mathrm{F}) \\
23.3 \pm 4.9 \\
\text { WC }(\mathrm{F}) \\
76.8 \pm 10.7 \mathrm{~cm} \\
\text { IL-6 (M): median } \\
\left(25^{\text {th }} ; 75^{\text {th }} \mathrm{percentiles}\right) \\
0.9(0.6 ; 1.6) \mathrm{pg} / \mathrm{mL} \\
\text { TNF- } \alpha(\mathrm{M}) \\
1.7(1.4 ; 2.2) \mathrm{pg} / \mathrm{mL}\end{array}$ & $\begin{array}{l}\text { Students } \\
\text { from } \\
\text { selected } \\
\text { secondary } \\
\text { schools for } \\
\text { a medical } \\
\text { check-up } \\
\text { by Public } \\
\text { Health } \\
\text { Office in } \\
\text { Dusseldorf }\end{array}$ & $\begin{array}{l}\text { Cross- } \\
\text { sectional } \\
\text { In } 2005\end{array}$ & $\begin{array}{l}\text { BMI }\left(\mathrm{kg} / \mathrm{m}^{2}\right) \\
\text { WC }(\mathrm{cm}): \\
\text { measured at a } \\
\text { level midway } \\
\text { between the } \\
\text { lower rib } \\
\text { margin and } \\
\text { iliac crest to } \\
\text { the nearest } \\
0.5 \mathrm{~cm} .\end{array}$ & $\begin{array}{l}\text { IL-6 (pg/mL) } \\
\text { Serum } \\
\text { ELISA } \\
\text { Intra-assay CV } \\
=5.2 \% \\
\text { Inter-assay CV } \\
=15.5 \% \\
\text { Sensitivity } \\
=0.08 \mathrm{pg} / \mathrm{ml} \\
\\
\text { TNF- } \alpha \text { (pg/mL) } \\
\text { Serum } \\
\text { ELISA } \\
\text { Intra-assay CV } \\
=6.7 \% \\
\text { Inter-assay CV } \\
=8.8 \% \\
\text { Sensitivity } \\
=0.25 \mathrm{pg} / \mathrm{ml} \\
\\
\text { Overnight fast }\end{array}$ & $\begin{array}{l}\text { IL-6 was } \\
\text { significantly } \\
\text { associated with } \\
\text { both higher BMI } \\
\text { and higher WC } \\
(p \leq 0.001) \text {. } \\
\text { TNF- } \alpha \text { was not } \\
\text { significantly } \\
\text { associated with } \\
\text { both BMI and } \\
\text { WC ( } p=\text { NS). }\end{array}$ & $\begin{array}{c}\text { Linear regression } \\
\beta: \text { regression coefficients } \\
\text { IL-6 (ln-transformed) } \\
\text { BMI: } \beta=0.033 \\
(p<0.001) \\
\text { WC: } \beta=0.011 \\
(p=0.001) \\
\\
\\
\text { TNF- } \alpha \text { (In-transformed) } \\
\text { BMI: } \beta=-0.003 \\
(p=0.395 ; \mathrm{NS}) \\
\text { WC: } \beta=-0.003 \\
(p=0.114 ; \mathrm{NS})\end{array}$ & $\begin{array}{l}\text { Age, sex, } \\
\text { lipids }\end{array}$ \\
\hline
\end{tabular}




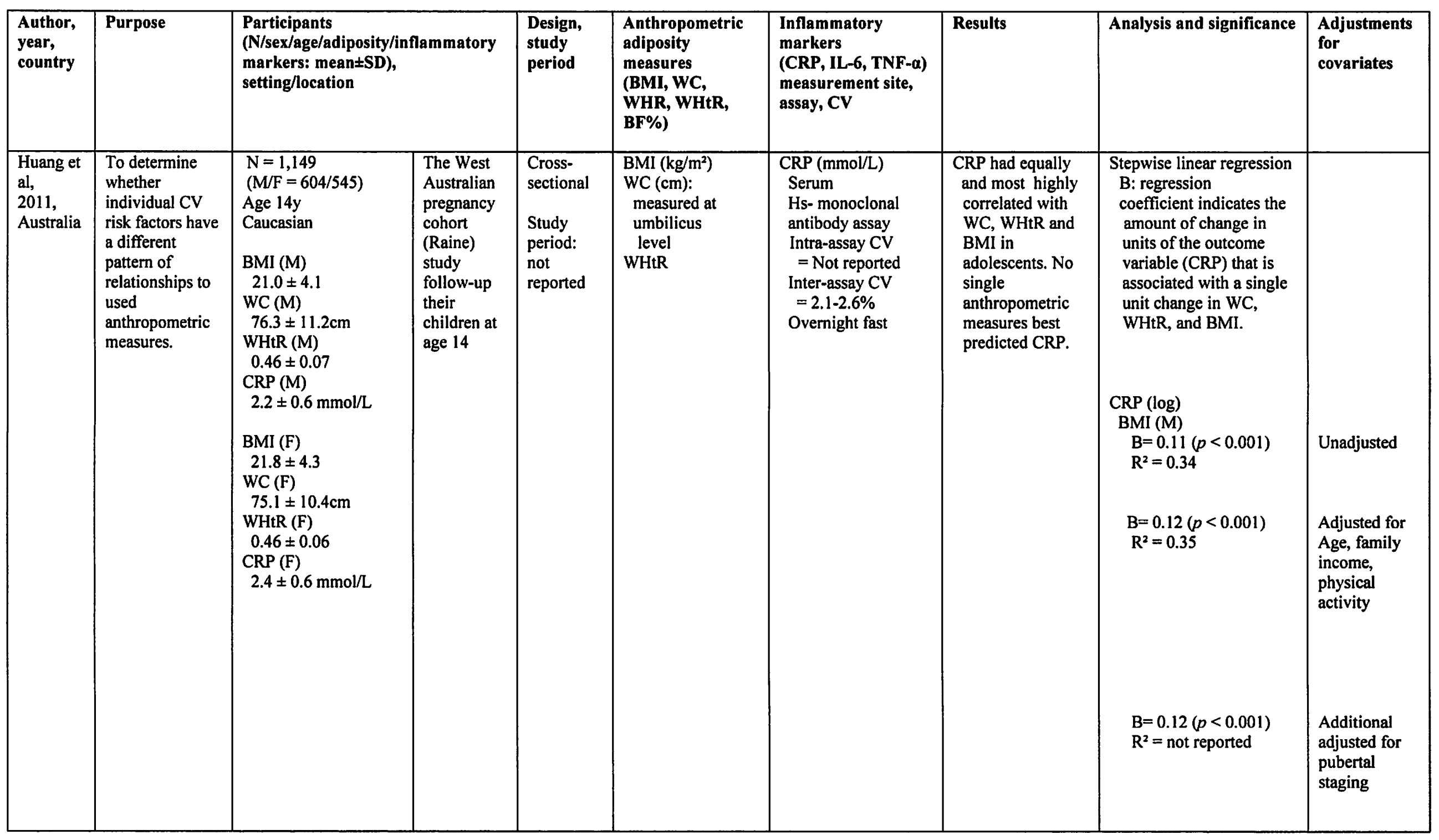




\begin{tabular}{|c|c|c|c|c|c|c|c|c|}
\hline $\begin{array}{l}\text { Author, } \\
\text { year, } \\
\text { country }\end{array}$ & Purpose & $\begin{array}{l}\text { Participants } \\
\text { (N/sex/age/adiposity/inflammatory } \\
\text { markers: mean } \pm \text { SD), } \\
\text { setting/location }\end{array}$ & $\begin{array}{l}\text { Design, } \\
\text { study } \\
\text { period }\end{array}$ & $\begin{array}{l}\text { Anthropometric } \\
\text { adiposity } \\
\text { measures } \\
\text { (BMI, WC, } \\
\text { WHR, WHtR, } \\
\text { BF\%) }\end{array}$ & $\begin{array}{l}\text { Inflammatory } \\
\text { markers } \\
\text { (CRP, IL-6, TNF- } \alpha \text { ) } \\
\text { measurement site, } \\
\text { assay, CV }\end{array}$ & Results & Analysis and significance & $\begin{array}{l}\text { Adjustments } \\
\text { for } \\
\text { covariates }\end{array}$ \\
\hline & & & & & & & 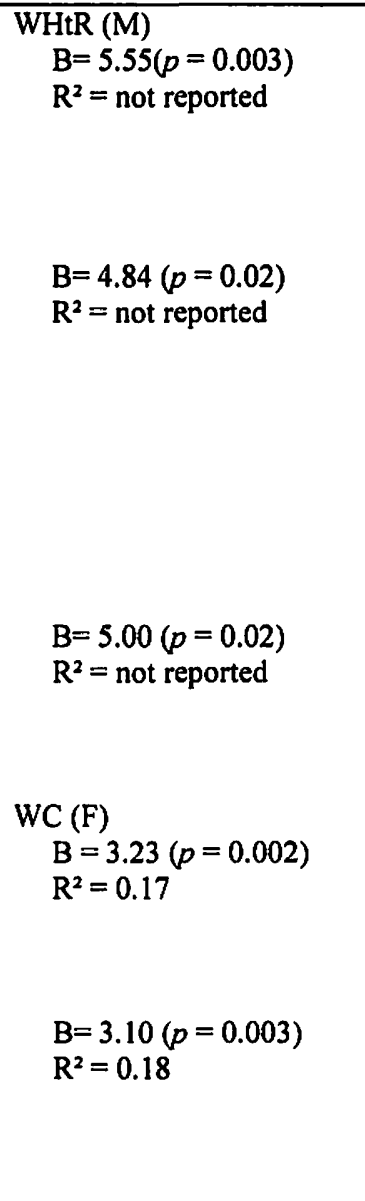 & $\begin{array}{l}\text { Unadjusted } \\
\text { Adjusted for } \\
\text { Age, family } \\
\text { income, } \\
\text { physical } \\
\text { activity } \\
\\
\text { Additional } \\
\text { adjusted for } \\
\text { pubertal } \\
\text { staging } \\
\text { Unadjusted } \\
\text { Ung } \\
\text { Adjusted for } \\
\text { Age, family } \\
\text { income, } \\
\text { physical } \\
\text { activity }\end{array}$ \\
\hline
\end{tabular}




\begin{tabular}{|c|c|c|c|c|c|c|c|c|c|}
\hline \multirow[t]{2}{*}{$\begin{array}{l}\text { Author, } \\
\text { year, } \\
\text { country }\end{array}$} & \multirow[t]{2}{*}{ Purpose } & \multicolumn{2}{|c|}{$\begin{array}{l}\text { Participants } \\
\text { (N/sex/age/adiposity/inflammatory } \\
\text { markers: mean } \pm \text { SD), } \\
\text { setting/location }\end{array}$} & \multirow[t]{2}{*}{$\begin{array}{l}\text { Design, } \\
\text { study } \\
\text { period }\end{array}$} & \multirow[t]{2}{*}{$\begin{array}{l}\text { Anthropometric } \\
\text { adiposity } \\
\text { measures } \\
\text { (BMI, WC, } \\
\text { WHR, WHtR, } \\
\text { BF\%) }\end{array}$} & \multirow[t]{2}{*}{$\begin{array}{l}\text { Inflammatory } \\
\text { markers } \\
\text { (CRP, IL-6, TNF- } \alpha \text { ) } \\
\text { measurement site, } \\
\text { assay, CV }\end{array}$} & \multirow[t]{2}{*}{ Results } & Analysis and significance & $\begin{array}{l}\text { Adjustments } \\
\text { for } \\
\text { covariates }\end{array}$ \\
\hline & & & & & & & & $\begin{array}{l}\mathrm{B}=3.05(p=0.01) \\
\mathrm{R}^{2}=\mathrm{NA}\end{array}$ & $\begin{array}{l}\text { Additional } \\
\text { adjusted for } \\
\text { pubertal } \\
\text { staging }\end{array}$ \\
\hline $\begin{array}{l}\text { Jung et } \\
\text { al, 2008, } \\
\text { Germany }\end{array}$ & $\begin{array}{l}\text { To investigate } \\
\text { whether WC, } \\
\text { BMI standard } \\
\text { deviation score } \\
\text { predict classical } \\
\text { and new } \\
\text { markers of CV } \\
\text { risk and diabetes } \\
\text { in male } \\
\text { Caucasian } \\
\text { adolescents. }\end{array}$ & $\begin{array}{l}\mathrm{N}=79(\mathrm{M}) \\
\text { Age } 13-17 \mathrm{y} \\
\text { Caucasian, } \\
\\
\text { BMI (Median (IQR)) } \\
22.8(20.5-30.5) \\
\text { WC }(\text { Median }(\mathrm{IQR})) \\
81(73-91) \mathrm{cm} \\
48 \%(\mathrm{n}=38) \text { had a } \\
\text { WC } \geq 90^{\text {th }} \\
\text { Percentile } \\
\text { Hs-CRP (Median } \\
(\mathrm{IQR})) \\
0.60(0.10-1.60) \\
\text { mg/L }\end{array}$ & $\begin{array}{l}\text { Volunteers } \\
\text { from } \\
\text { Schools of } \\
\text { the region } \\
\text { of Jena, } \\
\text { Germany }\end{array}$ & $\begin{array}{l}\text { Cross- } \\
\text { sectional } \\
\text { (Design: } \\
\text { not } \\
\text { reported) } \\
\text { Study } \\
\text { period: } \\
\text { not } \\
\text { reported }\end{array}$ & $\begin{array}{l}\text { WC }(\mathrm{cm}): \\
\text { Not reported }\end{array}$ & $\begin{array}{l}\text { Hs-CRP (mg/L) } \\
\text { Serum } \\
\text { ELISA } \\
\text { CV }=\text { Not reported } \\
\text { Overnight fast }\end{array}$ & $\begin{array}{l}\text { WC predicts hs- } \\
\text { CRP }(p<0.001)\end{array}$ & $\begin{array}{l}\text { Linear regression } \\
\text { HsCRP } \\
\text { WC: } \mathrm{R}^{2}=0.214 \\
(p<0.001)\end{array}$ & No \\
\hline $\begin{array}{l}\text { Khan et } \\
\text { al, 2010, } \\
\text { USA }\end{array}$ & $\begin{array}{l}\text { To examine the } \\
\text { association of a } \\
\text { five percent } \\
\text { change in BMI } \\
\text { over a six-month } \\
\text { time period on } \\
\text { levels of } \\
\text { traditional and } \\
\text { newer CVD risk } \\
\text { markers in a } \\
\text { clinical } \\
\text { population of } \\
\text { severely obese, }\end{array}$ & $\begin{array}{l}\mathrm{N}=83 \text { (baseline) } \\
(\mathrm{M} / \mathrm{F}=33 / 50) \\
\text { Age } 15.1 \pm 2.0 \mathrm{y} \\
\mathrm{AA}=47 \\
\text { Hispanic }=36 \\
\text { Severely obese (BMI } \\
>95^{\text {th }} \text { percentile for } \\
\text { age and sex) } \\
\text { adolescents } \\
\text { BMI : } 42.3 \pm 7.8 \\
\mathrm{CRP} \text { (median (IQR)) }\end{array}$ & $\begin{array}{l}\text { A } \\
\text { consecutive } \\
\text { sampling } \\
\text { from } \\
\text { Children's } \\
\text { hospital } \\
\text { weight loss } \\
\text { clinic at } \\
\text { initial visit, } \\
\text { and six- } \\
\text { month } \\
\text { At } 6 \text { month } \\
\text { follow up }\end{array}$ & $\begin{array}{l}\text { A six- } \\
\text { month } \\
\text { longitudin } \\
\text { al study }\end{array}$ & $\begin{array}{l}\text { BMI }\left(\mathrm{kg} / \mathrm{m}^{2}\right): \\
\text { At baseline }\end{array}$ & $\begin{array}{l}\text { CRP (mg/dL): } \\
\text { At baseline } \\
\text { Measurement site } \\
=\text { Not reported } \\
\text { Latex } \\
\text { enhanced } \\
\text { immune- } \\
\text { turbidometry } \\
\text { Intra-assay CV } \\
<5 \% \\
\text { Inter-assay CV } \\
=\text { Not reported } \\
\text { Overnight fast }\end{array}$ & $\begin{array}{l}\text { BMI remained } \\
\text { significantly } \\
\text { associated with } \\
\text { CRP after } \\
\text { adjusting for } \\
\text { age, sex, and } \\
\text { ethnicity }\end{array}$ & $\begin{array}{l}\text { Bivariate correlation } \\
\text { (at baseline) } \\
\text { BMI: Spearman's } \\
\text { rho }=0.50(p<0.001)\end{array}$ & $\begin{array}{l}\text { Adjusted for } \\
\text { age, sex, } \\
\text { ethnicity }\end{array}$ \\
\hline
\end{tabular}




\begin{tabular}{|c|c|c|c|c|c|c|c|c|c|}
\hline \multirow[t]{2}{*}{$\begin{array}{l}\text { Author, } \\
\text { year, } \\
\text { country }\end{array}$} & \multirow{2}{*}{$\begin{array}{l}\text { Purpose } \\
\\
\text { AA and } \\
\text { Hispanic } \\
\text { adolescents. }\end{array}$} & \multicolumn{2}{|c|}{$\begin{array}{l}\text { Participants } \\
\text { (N/sex/age/adiposity/inflammatory } \\
\text { markers: mean } \pm \text { SD), } \\
\text { setting/location }\end{array}$} & $\begin{array}{l}\text { Design, } \\
\text { study } \\
\text { period }\end{array}$ & \multirow{2}{*}{$\begin{array}{l}\text { Anthropometric } \\
\text { adiposity } \\
\text { measures } \\
\text { (BMI, WC, } \\
\text { WHR, WHtR, } \\
\text { BF\%) } \\
\\
\text { BMI }\left(\mathrm{kg} / \mathrm{m}^{2}\right): \\
6 \text { month follow up }\end{array}$} & \multirow{2}{*}{$\begin{array}{l}\text { Inflammatory } \\
\text { markers } \\
\text { (CRP, IL-6, TNF-a) } \\
\text { measurement site, } \\
\text { assay, CV } \\
\\
\text { CRP (mg/dL): } \\
6 \text { month follow up }\end{array}$} & \multirow{2}{*}{$\begin{array}{l}\text { Results } \\
\\
(p=0.001) \text { at } \\
\text { baseline. } \\
\text { At } 6 \text { month follow } \\
\text { up, comparison of } \\
\text { changes in CRP } \\
\text { level with change } \\
\text { in BMI, there was } \\
\text { a significant ( } p= \\
0.05 \text { for trend) } \\
\text { between the three } \\
\text { groups of BMI } \\
\text { change. }\end{array}$} & \multirow{2}{*}{$\begin{array}{l}\text { Analysis and significance } \\
\\
\\
\\
\text { At } 6 \text { month follow up } \\
\text { CRP (mg/dL) changes: } \\
\text { median }(\mathrm{IQR}) \\
\geq 5 \% \mathrm{BMI} \text { increase } \\
0.1(0,0.5)(\mathrm{N}=8) \\
\mathrm{BMI} \text { within } 5 \% \\
0(-0.2,0.2)(\mathrm{N}=32) \\
\geq 5 \% \mathrm{BMI} \text { decrease } \\
0(-0.4,0)(\mathrm{N}=10) \\
(p=0.05: \text { for trend })\end{array}$} & \multirow{2}{*}{$\begin{array}{l}\text { Adjustments } \\
\text { for } \\
\text { covariates }\end{array}$} \\
\hline & & $0.5(0.1,1.1) \mathrm{mg} / \mathrm{dL}$ & $N=50$ & & & & & & \\
\hline $\begin{array}{l}\text { Martinez } \\
\text {-Gomez, } \\
\text { et al, } \\
2010 \text {, } \\
\text { Spain }\end{array}$ & $\begin{array}{l}\text { To examine the } \\
\text { independent } \\
\text { associations of } \\
\text { objective } \\
\text { measured } \\
\text { physical } \\
\text { activity, } \\
\text { cardiorespirator } \\
\text { y fitness, and } \\
\text { fatness with } \\
\text { low-grade } \\
\text { inflammatory } \\
\text { markers in } \\
\text { adolescents. }\end{array}$ & $\begin{array}{l}\mathrm{N}=192 \\
(\mathrm{M} / \mathrm{F}=98 / 94) \\
\text { Age } 13-17 \mathrm{y} \\
\\
\text { BMI }(\mathrm{M}+\mathrm{F}) \\
21.7 \pm 3.5 \\
\mathrm{WC}(\mathrm{M}+\mathrm{F}) \\
73.4 \pm 9.4 \mathrm{~cm} \\
\mathrm{BF}(\mathrm{M}+\mathrm{F}) \\
33.5 \pm 12.1 \mathrm{~mm} \\
\mathrm{CRP}(\mathrm{M}+\mathrm{F}) \\
0.7 \pm 1.3 \mathrm{mg} / \mathrm{dL} \\
\mathrm{IL}-6(\mathrm{M}+\mathrm{F}) \\
16.6 \pm 28.6 \mathrm{pg} / \mathrm{mL}\end{array}$ & $\begin{array}{l}\text { A sub- } \\
\text { sample } \\
\text { from the } \\
\text { AFINOS } \\
\text { surveillanc } \\
\text { e study: } \\
\text { volunteer } \\
\text { adolescents } \\
\text { in the } \\
\text { region of } \\
\text { Madrid }\end{array}$ & $\begin{array}{l}\text { Cross- } \\
\text { sectional } \\
\text { November } \\
2007- \\
\text { February } \\
2008\end{array}$ & $\begin{array}{l}\text { BMI }\left(\mathrm{kg} / \mathrm{m}^{2}\right) \\
\text { WC (cm): } \\
\text { Not reported } \\
\text { BF (mm) } \\
\text { measured by } \\
\text { sum of six } \\
\text { SFs (triceps, } \\
\text { biceps, } \\
\text { subscapular, } \\
\text { suprailiac, } \\
\text { thigh, calf) } \\
\text { using skinfold } \\
\text { caliper }\end{array}$ & $\begin{array}{l}\text { CRP (mg/L) } \\
\text { Serum } \\
\text { Immuno- } \\
\text { turbidimetry } \\
\text { CV= Not reported } \\
\\
\text { IL-6 (pg/mL) } \\
\text { Serum } \\
\text { Hs-Human } \\
\text { Cytokine } \\
\text { MILLIPLEX } \\
\text { MAP kit } \\
\text { CV= Not reported } \\
\text { Overnight fast }\end{array}$ & $\begin{array}{l}\text { BMI, WC, and BF } \\
\text { were not } \\
\text { significant } \\
\text { association with } \\
\text { IL-6. }\end{array}$ & $\begin{array}{l}\text { Partial correlations } \\
\text { CRP (log) } \\
\text { BMI: } r=0.250 \\
(p<0.001) \\
\text { WC: } r=0.301 \\
(p<0.001) \\
\text { BF: } r=0.236 \\
(p<0.001) \\
\text { IL-6 (square-root- } \\
\text { transformed) } \\
\text { BMI: } r=-0.014 \\
(p=\mathrm{NS}) \\
\text { WC: } r=0.031 \\
(p=N S) \\
\text { BF: } r=0.050(p=\text { NS) }\end{array}$ & $\begin{array}{l}\text { Adjusted for } \\
\text { age, sex, and } \\
\text { pubertal } \\
\text { status }\end{array}$ \\
\hline
\end{tabular}




\begin{tabular}{|c|c|c|c|c|c|c|c|c|c|}
\hline \multirow[t]{2}{*}{$\begin{array}{l}\text { Author, } \\
\text { year, } \\
\text { country }\end{array}$} & \multirow[t]{2}{*}{ Purpose } & \multicolumn{2}{|c|}{$\begin{array}{l}\text { Participants } \\
\text { (N/sex/age/adiposity/inflammatory } \\
\text { markers: mean } \pm \text { SD), } \\
\text { setting/location }\end{array}$} & $\begin{array}{l}\text { Design, } \\
\text { study } \\
\text { period }\end{array}$ & $\begin{array}{l}\text { Anthropometric } \\
\text { adiposity } \\
\text { measures } \\
\text { (BMI, WC, } \\
\text { WHR, WHtR, } \\
\text { BF\%) }\end{array}$ & $\begin{array}{l}\text { Inflammatory } \\
\text { markers } \\
\text { (CRP, IL-6, TNF- } \alpha \text { ) } \\
\text { measurement site, } \\
\text { assay, CV }\end{array}$ & Results & Analysis and significance & $\begin{array}{l}\text { Adjustments } \\
\text { for } \\
\text { covariates }\end{array}$ \\
\hline & & & & & & & & $\begin{array}{c}\text { Multiple regression } \\
\text { CRP (log) } \\
\text { BF: } \beta=0.241 \\
(p=0.002) \\
\mathrm{R}^{2}=0.040 \\
\text { IL-6 (square-root- } \\
\text { transformed) } \\
\text { BF: } \beta=-0.016 \\
(p=0.842) \\
\mathrm{R}^{2}=0.005\end{array}$ & $\begin{array}{l}\text { Adjusted for } \\
\text { age, sex, } \\
\text { pubertal } \\
\text { status, and } \\
\text { HOMA-IR }\end{array}$ \\
\hline $\begin{array}{l}\text { Moon et } \\
\text { al, 2004, } \\
\text { South } \\
\text { Korea }\end{array}$ & $\begin{array}{l}\text { To evaluate the } \\
\text { relationship } \\
\text { between serum } \\
\text { TNF- } \alpha \text {, its } \\
\text { receptors, and } \\
\text { metabolic } \\
\text { syndrome } \\
\text { components and } \\
\text { anthropometric } \\
\text { indices in obese } \\
\text { and non-obese } \\
\text { Asian } \\
\text { adolescents. }\end{array}$ & $\begin{array}{l}\mathrm{N}=71 \\
(\mathrm{M} / \mathrm{F}=26 / 45) \\
\text { Age } 15-16 \mathrm{y} \\
\text { Asian } \\
\text { Non-obese }(\mathrm{BMI}< \\
23): \mathrm{N}=32 \\
(\mathrm{M} / \mathrm{F}=14 / 25) \\
\mathrm{BMI} 20.6 \pm 0.86 \\
\text { WC } 74.83 \pm 3.96 \mathrm{~cm} \\
\text { Obese }(\mathrm{BMI}>25) \\
: \mathrm{N}=39 \\
(\mathrm{M} / \mathrm{F}=12 / 20) \\
\text { BMI } 29.44 \pm 2.92 \\
\text { WC } 93.83 \pm 5.55 \mathrm{~cm} \\
\text { using Asia- Pacific } \\
\text { criteria } \\
\text { of obesity } \\
\text { TNF- } \alpha \text { was not } \\
\text { reported }\end{array}$ & $\begin{array}{l}\text { Sampling/ } \\
\text { setting/loca } \\
\text { tion were } \\
\text { not } \\
\text { reported }\end{array}$ & $\begin{array}{l}\text { Cross- } \\
\text { sectional } \\
\text { Study } \\
\text { period: } \\
\text { Not } \\
\text { reported }\end{array}$ & $\begin{array}{l}\text { BMI }\left(\mathrm{kg} / \mathrm{m}^{2}\right) \\
\text { WC }(\mathrm{cm}): \\
\text { measured } \\
\text { midway } \\
\text { between the } \\
\text { lowest rib } \\
\text { margin and the } \\
\text { iliac crest at } \\
\text { the end of } \\
\text { gentle } \\
\text { expiration }\end{array}$ & $\begin{array}{l}\text { TNF- } \alpha(\mathrm{pg} / \mathrm{mL}) \\
\text { Serum } \\
\text { ELISA } \\
\text { Intra-assay CV } \\
<7 \% \\
\text { Inter-assay CV } \\
<9 \% \\
\text { Sensitivity } \\
=3 \mathrm{pg} / \mathrm{ml} \\
\text { Overnight fast }\end{array}$ & $\begin{array}{l}\text { The serum TNF- } \alpha \\
\text { concentration } \\
\text { was positively } \\
\text { correlated with } \\
\text { both the BMI ( } p \\
<0.005) \text { and WC } \\
(p<0.001) \text {. }\end{array}$ & $\begin{array}{l}\text { Linear correlation } \\
\text { BMI: } r=0.346 \\
(p<0.005) \\
\text { WC: } r=0.525 \\
(p<0.001)\end{array}$ & No \\
\hline
\end{tabular}




\begin{tabular}{|c|c|c|c|c|c|c|c|c|c|}
\hline $\begin{array}{l}\text { Author, } \\
\text { year, } \\
\text { country }\end{array}$ & Purpose & \multicolumn{2}{|c|}{$\begin{array}{l}\text { Participants } \\
\text { (N/sex/age/adiposity/inflammatory } \\
\text { markers: mean } \pm \text { SD), } \\
\text { setting/location }\end{array}$} & $\begin{array}{l}\text { Design, } \\
\text { study } \\
\text { period }\end{array}$ & $\begin{array}{l}\text { Anthropometric } \\
\text { adiposity } \\
\text { measures } \\
\text { (BMI, WC, } \\
\text { WHR, WHtR, } \\
\text { BF\%) }\end{array}$ & $\begin{array}{l}\text { Inflammatory } \\
\text { markers } \\
\text { (CRP, IL-6, TNF- } \alpha \text { ) } \\
\text { measurement site, } \\
\text { assay, CV }\end{array}$ & Results & Analysis and significance & $\begin{array}{l}\text { Adjustments } \\
\text { for } \\
\text { covariates }\end{array}$ \\
\hline $\begin{array}{l}\text { Petty et } \\
\text { al, } 2010 \text {, } \\
\text { USA }\end{array}$ & $\begin{array}{l}\text { To examine the } \\
\text { sex-specific } \\
\text { association of } \\
\text { adiposity } \\
\text { variables with } \\
\text { five } \\
\text { inflammation } \\
\text { markers: IL-6, } \\
\text { leptin, CRP, } \\
\text { adiponectin, and } \\
\text { MCP1 in AA } \\
\text { adolescents. }\end{array}$ & $\begin{array}{l}\mathrm{N}=166 \\
(\mathrm{M} / \mathrm{F}=78 / 88) \\
\text { Age } 14-19 \mathrm{y} \\
\text { AA } \\
\\
\text { BMI (M) } \\
24.35 \pm 4.7 \\
\text { WC (M) } \\
80.32 \pm 11.43 \mathrm{~cm} \\
\text { CRP (M) } \\
1.01 \pm 1.8 \mathrm{ug} / \mathrm{mL} \\
\text { IL-6 (M) } \\
1.29 \pm 1.3 \mathrm{pg} / \mathrm{mL} \\
\\
\text { BMI (F) } \\
26.16 \pm 6.6 \\
\text { WC (F) } \\
78.46 \pm 11.34 \mathrm{~cm} \\
\text { CRP (F) } \\
1.27 \pm 1.8 \mathrm{ug} / \mathrm{mL} \\
\text { IL-6 (F) } \\
1.80 \pm 1.7 \mathrm{pg} / \mathrm{mL}\end{array}$ & $\begin{array}{l}\text { AA } \\
\text { volunteers } \\
\text { in local } \\
\text { public high } \\
\text { schools in } \\
\text { the } \\
\text { Augusta } \\
\text { Richmond } \\
\text { Country }\end{array}$ & $\begin{array}{l}\text { Cross- } \\
\text { sectional } \\
\text { June } \\
2006-J u l y \\
2008\end{array}$ & $\begin{array}{l}\text { BMI }\left(\mathrm{kg} / \mathrm{m}^{2}\right) \\
\text { WC }(\mathrm{cm}): \\
\text { measured with } \\
\text { thin clothing on, } \\
\text { at the midpoint } \\
\text { between the } \\
\text { lowest rib and } \\
\text { the iliac crest. }\end{array}$ & $\begin{array}{l}\text { Hs-CRP (ug/mL) } \\
\text { Plasma } \\
\text { ELISA } \\
\text { Inter-assay CV } \\
<7.0 \% \\
\text { Intra-assay CV } \\
<8.3 \% \\
\text { IL-6 (pg/mL) } \\
\text { Plasma } \\
\text { ELISA } \\
\text { Intra-assay CV } \\
<7.8 \% \\
\text { Inter-assay CV } \\
<9.6 \% \\
\text { Non-fasting }\end{array}$ & $\begin{array}{l}\text { In males, CRP and } \\
\text { IL-6 were not } \\
\text { significantly } \\
\text { associated with } \\
\text { BMI and WC. } \\
\\
\text { In females, CRP } \\
\text { was significantly } \\
\text { associated with } \\
\text { BMl ( } p<0.01) \\
\text { and WC ( } p< \\
0.001), \text { whereas } \\
\text { IL-6 was } \\
\text { not significantly } \\
\text { associated with } \\
\text { BMI and WC. }\end{array}$ & $\begin{array}{c}\text { Partial correlations } \\
\text { CRP (M) (log) } \\
\text { BMI: } r=0.179 \\
(p=\mathrm{NS}) \\
\text { WC: } r=0.173(p=\mathrm{NS}) \\
\text { IL-6(M) }(\log ) \\
\text { BMI: } r=0.130 \\
\quad(p=\mathrm{NS}) \\
\text { WC: } r=0.093(p=\mathrm{NS})\end{array}$ & $\begin{array}{l}\text { Adjusted for } \\
\text { age }\end{array}$ \\
\hline $\begin{array}{l}\text { Serrano } \\
\text { et al, } \\
2010 \text {, } \\
\text { Brazil }\end{array}$ & $\begin{array}{l}\text { To evaluate } \\
\text { body } \\
\text { composition, } \\
\text { anthropometric } \\
\text { changes, } \\
\text { biochemical and } \\
\text { clinical } \\
\text { characteristics } \\
\text { of female } \\
\end{array}$ & $\begin{array}{l}\mathrm{N}=113(\mathrm{~F}) \\
\text { Age 14-18y } \\
\\
\text { BMI } 22.90 \pm 4.1 \\
\text { WC } 71.01 \pm 7.78 \mathrm{~cm} \\
\text { WHR } 0.80 \pm 0.04 \\
\text { BF } 28.72 \pm 5.14 \% \\
\text { CRP } 3.572 \pm 3.732 \\
\mathrm{mg} / \mathrm{dL} \\
\end{array}$ & $\begin{array}{l}\text { Public } \\
\text { schools in } \\
\text { Viçosa, } \\
\text { Minas } \\
\text { Gerais }\end{array}$ & $\begin{array}{l}\text { Cross- } \\
\text { sectional } \\
\text { Study } \\
\text { period: } \\
\text { Not } \\
\text { reported }\end{array}$ & $\begin{array}{l}\mathrm{BMI}\left(\mathrm{kg} / \mathrm{m}^{2}\right) \\
\text { WC }(\mathrm{cm}): \\
\text { measured at } \\
\text { the minimum } \\
\text { circumference } \\
\text { between the } \\
\text { iliac crest and } \\
\text { the rib cage } \\
\text { WHR }(\mathrm{cm} / \mathrm{cm})\end{array}$ & $\begin{array}{l}\text { CRP (mg/dL) } \\
\text { Site, assay, and } \\
\mathrm{CV}=\text { Not } \\
\text { reported } \\
\text { Overnight fast }\end{array}$ & $\begin{array}{l}\text { CRP was not } \\
\text { correlated with } \\
\text { BMI, WC, WHR, } \\
\text { and } \mathrm{BF}(\%) \text {. }\end{array}$ & $\begin{array}{c}\text { Pearson correlation } \\
\text { CRP (positive values) } \\
\text { BMI: } r=-0.056 \\
(p=0.823) \\
\text { WC: } r=-0.05 \\
(p=0.845) \\
\text { WHR: } r=-0.144 \\
(p=0.569) \\
\text { BF\%: } r=0.112\end{array}$ & No \\
\hline
\end{tabular}




\begin{tabular}{|c|c|c|c|c|c|c|c|c|c|}
\hline \multirow[t]{2}{*}{$\begin{array}{l}\text { Author, } \\
\text { year, } \\
\text { country }\end{array}$} & Purpose & \multicolumn{2}{|c|}{$\begin{array}{l}\text { Participants } \\
\text { (N/sex/age/adiposity/inflammatory } \\
\text { markers: mean } \pm \text { SD), } \\
\text { setting/location }\end{array}$} & $\begin{array}{l}\text { Design, } \\
\text { study } \\
\text { period }\end{array}$ & $\begin{array}{l}\text { Anthropometric } \\
\text { adiposity } \\
\text { measures } \\
\text { (BMI, WC, } \\
\text { WHR, WHtR, } \\
\text { BF\%) }\end{array}$ & $\begin{array}{l}\text { Inflammatory } \\
\text { markers } \\
\text { (CRP, IL-6, TNF-a) } \\
\text { measurement site, } \\
\text { assay, CV }\end{array}$ & Results & Analysis and significance & $\begin{array}{l}\text { Adjustments } \\
\text { for } \\
\text { covariates }\end{array}$ \\
\hline & adolescents. & & & & $\begin{array}{l}\text { BF\%: } \\
\text { measured } \\
\text { by } \\
\text { bioelectrical } \\
\text { impedance } \\
\text { Hip (cm): } \\
\text { measured at the } \\
\text { maximum } \\
\text { protuberance of } \\
\text { the buttocks }\end{array}$ & & & $(p=0.659)$ & \\
\hline $\begin{array}{l}\text { Vikram } \\
\text { et al, } \\
2006, \\
\text { India }\end{array}$ & $\begin{array}{l}\text { To examine the } \\
\text { association of } \\
\text { serum hs-CRP } \\
\text { with fasting } \\
\text { insulin and } \\
\text { insulin } \\
\text { resistance in } \\
\text { urban adolescent } \\
\text { and young adult } \\
\text { males in north } \\
\text { India. }\end{array}$ & $\begin{array}{l}\mathrm{N}=324(\mathrm{M}) \\
\text { Age } 14-25 \mathrm{y} \\
\text { BMI } 20.1 \pm 3.5 \\
\text { WC } 70.7 \pm 7.8 \mathrm{~cm} \\
\text { WHR } 0.82 \pm 0.04 \\
\text { CRP }(\text { Geometric } \\
\text { mean }(95 \% \mathrm{CI})) \\
0.63(0.56-0.71) \\
\mu \mathrm{g} / \mathrm{mL}\end{array}$ & $\begin{array}{l}\text { Participants } \\
\text { selected } \\
\text { randomly } \\
\text { from } \\
\text { schools and } \\
\text { colleges in } \\
\text { southwest } \\
\text { New Delhi, } \\
\text { multistage } \\
\text { cluster } \\
\text { sampling }\end{array}$ & $\begin{array}{l}\text { Cross- } \\
\text { sectional } \\
\text { In 2001- } \\
2003\end{array}$ & $\begin{array}{l}\text { BMI }\left(\mathrm{kg} / \mathrm{m}^{2}\right) \\
\text { WC }(\mathrm{cm}): \\
\text { measured } \\
\text { midway } \\
\text { between the } \\
\text { iliac crest and } \\
\text { the lower-most } \\
\text { margin of the } \\
\text { ribs } \\
\text { WHR } \\
\text { BF\%: } \\
\text { measured by } \\
\text { bioelectrical } \\
\text { impedance } \\
\text { Hip (cm): } \\
\text { measured at the } \\
\text { maximum } \\
\text { circumference of } \\
\text { the buttocks, } \\
\text { subject standing } \\
\text { with feet placed } \\
\text { together }\end{array}$ & $\begin{array}{l}\text { Hs-CRP }(\mu \mathrm{g} / \mathrm{mL}) \\
\text { Serum } \\
\text { ELISA } \\
\text { Intra-assay CV } \\
=1.7 \% \\
\text { Inter-assay CV } \\
=3.3 \% \\
\text { Overnight fast }\end{array}$ & $\begin{array}{l}\text { Hs-CRP levels } \\
\text { correlated } \\
\text { significantly with } \\
\text { BMI, WC, and } \\
\text { WHR }(p<0.05) \text {. }\end{array}$ & $\begin{array}{l}\text { Pearson correlation } \\
\text { Hs-CRP (log) } \\
\text { BMI: } r=0.14 \\
\quad(p<0.01) \\
\text { WC: } r=0.17(P<0.01) \\
\text { WHR: } r=0.16 \\
\quad(p<0.01) \\
\text { BF\%: } r=0.07(p=\mathrm{NS})\end{array}$ & No \\
\hline
\end{tabular}




\begin{tabular}{|c|c|c|c|c|c|c|c|c|c|}
\hline $\begin{array}{l}\text { Author, } \\
\text { year, } \\
\text { country }\end{array}$ & Purpose & $\begin{array}{l}\text { Participants } \\
\text { (N/sex/age/adiposity/in } \\
\text { markers: mean } \pm \mathrm{SD} \text { ), } \\
\text { setting/location }\end{array}$ & lammatory & $\begin{array}{l}\text { Design, } \\
\text { study } \\
\text { period }\end{array}$ & $\begin{array}{l}\text { Anthropometric } \\
\text { adiposity } \\
\text { measures } \\
\text { (BMI, WC, } \\
\text { WHR, WHtR, } \\
\text { BF\%) }\end{array}$ & $\begin{array}{l}\text { Inflammatory } \\
\text { markers } \\
\text { (CRP, IL-6, TNF- } \alpha \text { ) } \\
\text { measurement site, } \\
\text { assay, CV }\end{array}$ & Results & Analysis and significance & $\begin{array}{l}\text { Adjustments } \\
\text { for } \\
\text { covariates }\end{array}$ \\
\hline $\begin{array}{l}\text { Wang et } \\
\text { al, 2011, } \\
\text { China }\end{array}$ & $\begin{array}{l}\text { To examine the } \\
\text { impact of } \\
\text { pubertal } \\
\text { development, } \\
\text { gender, and } \\
\text { adiposity } \\
\text { distribution on } \\
\text { CRP levels in } \\
\text { adolescent } \\
\text { twins. }\end{array}$ & $\begin{array}{l}\mathrm{N}=1,180 \\
(\mathrm{M} / \mathrm{F}=632 / 548) \\
\text { Age } 13-21 \mathrm{y} \\
\text { Asian } \\
\\
\text { BMI }(\mathrm{M}) \\
18.7 \pm 2.3 \\
\text { WC (M) } \\
68.4 \pm 6.1 \mathrm{~cm} \\
\text { CRP (M) (Median } \\
(\mathrm{IQR})) \\
0.85(0.39-1.80) \mathrm{mg} / \mathrm{L} \\
\text { BMI (F) } \\
19.8 \pm 2.4 \\
\text { WC (F) } \\
66.1 \pm 6.3 \mathrm{~cm} \\
\text { CRP (M) (Median } \\
(\text { IQR)) } \\
0.75(0.34-1.72) \mathrm{mg} / \mathrm{L}\end{array}$ & $\begin{array}{l}\text { Large } \\
\text { community } \\
\text {-based } \\
\text { Chinese } \\
\text { twin cohort } \\
\text { in Anging, } \\
\text { China }\end{array}$ & $\begin{array}{l}\text { Cross- } \\
\text { sectional } \\
\text { In } 2005- \\
2006\end{array}$ & $\begin{array}{l}\text { BMI }\left(\mathrm{kg} / \mathrm{m}^{2}\right) \\
\text { WC }(\mathrm{cm}): \\
\text { measured at } \\
\text { the level of the } \\
\text { umbilicus to } \\
\text { the nearest } \\
\text { millimeter }\end{array}$ & $\begin{array}{l}\mathrm{CRP}(\mathrm{mg} / \mathrm{L}) \\
\text { Plasma } \\
\text { Sandwich } \\
\text { Immunoassay } \\
\text { Intra-assay CV } \\
<5.1 \% \\
\text { Inter-assay } \\
=\text { Not reported } \\
\text { Fasting: Not } \\
\text { reported }\end{array}$ & $\begin{array}{l}\text { BMI and WC were } \\
\text { linearly } \\
\text { associated with } \\
\log (C R P) \text { levels } \\
\text { both males and } \\
\text { females } \\
(p<0.05) \text {. }\end{array}$ & $\begin{array}{c}\text { Linear regression } \\
\beta: \text { coefficient } \\
\text { CRP (log) } \\
\text { BMI (M): } \beta=0.23 \\
(p<0.0001) \\
\text { Partial } r^{2}=0.0516 \\
\text { WC (M): } \beta=0.22 \\
(p<0.0001) \\
\text { Partial } r^{2}=0.0366 \\
\text { BMI (F): } \beta=0.31 \\
(p<0.0001) \\
\text { Partial } r^{2}=0.0665 \\
\text { WC (F): } \beta=0.31 \\
(p<0.0001) \\
\text { Partial } r^{2}=0.0788\end{array}$ & $\begin{array}{l}\text { Adjusted for } \\
\text { active/passive } \\
\text { smoking, } \\
\text { Tanner stage, } \\
\text { and age }\end{array}$ \\
\hline
\end{tabular}




\begin{tabular}{|c|c|c|c|c|c|c|c|c|c|}
\hline $\begin{array}{l}\text { Author, } \\
\text { year, } \\
\text { country }\end{array}$ & Purpose & $\begin{array}{l}\text { Participants } \\
\text { (N/sex/age/adiposity/in } \\
\text { markers: mean } \pm \text { SD), } \\
\text { setting/location }\end{array}$ & lammatory & $\begin{array}{l}\text { Design, } \\
\text { study } \\
\text { period }\end{array}$ & $\begin{array}{l}\text { Anthropometric } \\
\text { adiposity } \\
\text { measures } \\
\text { (BMI, WC, } \\
\text { WHR, WHtR, } \\
\text { BF\%) }\end{array}$ & $\begin{array}{l}\text { Inflammatory } \\
\text { markers } \\
\text { (CRP, IL-6, TNF- } \alpha \text { ) } \\
\text { measurement site, } \\
\text { assay, CV }\end{array}$ & Results & Analysis and significance & $\begin{array}{l}\text { Adjustments } \\
\text { for } \\
\text { covariates }\end{array}$ \\
\hline $\begin{array}{l}\text { Wärnber } \\
\text { et al, } \\
2006, \\
\text { Spain }\end{array}$ & $\begin{array}{l}\text { To establish the } \\
\text { possible } \\
\text { relations of } \\
\text { serum } \\
\text { inflammatory } \\
\text { proteins with } \\
\text { body fat } \\
\text { estimates and } \\
\text { body fat } \\
\text { distribution in } \\
\text { an apparently } \\
\text { healthy Spanish } \\
\text { adolescent } \\
\text { population. }\end{array}$ & 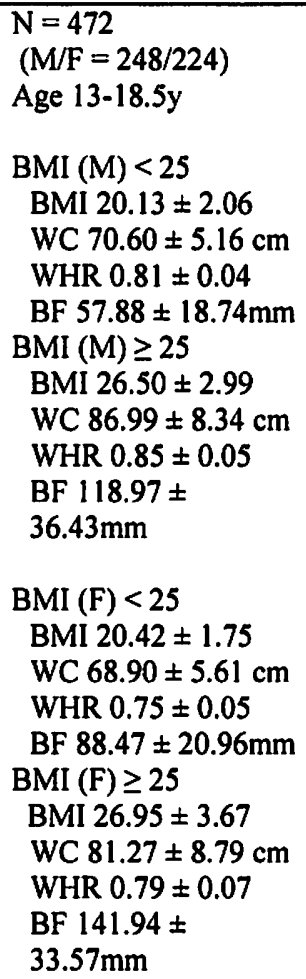 & $\begin{array}{l}\text { Multiple- } \\
\text { step } \\
\text { random } \\
\text { sampling } \\
\text { and then by } \\
\text { random } \\
\text { selection of } \\
\text { classrooms } \\
\text { from public } \\
\text { and private } \\
\text { schools in } \\
\text { each city, } \\
\text { and then } \\
\text { stratified } \\
\text { by age and } \\
\text { sex: the } \\
\text { multicenter } \\
\text { AVENA } \\
\text { study }\end{array}$ & $\begin{array}{l}\text { Cross- } \\
\text { sectional } \\
\text { In } 2000- \\
2002\end{array}$ & $\begin{array}{l}\text { BMI }\left(\mathrm{kg} / \mathrm{m}^{2}\right) \\
\text { WC }(\mathrm{cm}): \\
\text { Measured } \\
\text { midway } \\
\text { between the } \\
\text { lowest rib } \\
\text { margin and the } \\
\text { iliac crest after } \\
\text { gentle } \\
\text { expiration } \\
\text { WHR } \\
\text { BF (mm) } \\
\text { :6SF } \\
\text { (triceps, } \\
\text { biceps, } \\
\text { subscapular, } \\
\text { suprailiac, } \\
\text { thigh and calf) } \\
\text { Hip (cm): } \\
\text { measured at the } \\
\text { point yielding } \\
\text { the maximum } \\
\text { circumference } \\
\text { over the buttocks }\end{array}$ & $\begin{array}{l}\text { Hs-CRP (mg/L) } \\
\text { Serum } \\
\text { Immuno- } \\
\text { turbidimetry } \\
\text { Intra-assay CV } \\
=\text { Not reported } \\
\text { Inter-assay CV } \\
<2 \% \\
\text { Overnight fast }\end{array}$ & $\begin{array}{l}\text { Hs-CRP was } \\
\text { significantly } \\
\text { correlated with } \\
\text { BMI, WC, and } \\
\text { BF (sum of } 6 \text { SF } \\
\text { Thicknesses) } \\
(p<0.05) .\end{array}$ & $\begin{array}{c}\text { Partial correlation } \\
\text { In CRP (M) } \\
\text { BMI: } r=0.268 \\
(p=0.01) \\
\text { WC: } r=0.226 \\
(p=0.01) \\
\text { WHR: } r=0.107 \\
(p=\mathrm{NS}) \\
\text { BF: } r=0.280 \\
(p=0.01) \\
\text { In CRP (F) } \\
\text { BMI: } r=0.265 \\
(p=0.01) \\
\text { WC: } r=0.220 \\
(p=0.01) \\
\text { WHR: } r=0.004 \\
(p=N S) \\
\text { BF: } r=0.274 \\
(p=0.01)\end{array}$ & $\begin{array}{l}\text { Adjusted for } \\
\text { age and } \\
\text { Tanner stage }\end{array}$ \\
\hline
\end{tabular}

Abbreviations: N, number; M, male; F, female; BMI, body mass index; WC, waist circumference; WHR, waist to hip ratio; WHtR, waist to height ratio; BF, body fat; CRP, creactive protein; hs, high sensitivity: IL-6, interleukin 6; TNF- $\alpha$, tumor necrosis factor alpha; ELISA, enzyme-linked immunosorbent assay; RIA, radioimmunoassay; y, year; CV = coefficient of variation; OR, Odds Ratio; CI, confidence interval; NA, not applicable; NS, not significance; CV, cardiovascular; CVD, cardiovascular disease; HOMA-IR,

homeostasis model assessment of insulin resistance; SF, skinfold; ref, reference; AA, African American; log, log transformed (logarithmically transformed); IQR, interquartile range 
Table 2

Studies reporting the association of anthropometric adiposity and inflammatory biomarkers in young adults

\begin{tabular}{|c|c|c|c|c|c|c|c|c|c|}
\hline $\begin{array}{l}\text { Author, } \\
\text { year, } \\
\text { country }\end{array}$ & Purpose & $\begin{array}{l}\text { Participants } \\
\text { (N/sex/age/adiposity/in } \\
\text { markers: mean } \pm \text { SD), } \\
\text { setting/location }\end{array}$ & lammatory & $\begin{array}{l}\text { Design, } \\
\text { study } \\
\text { period }\end{array}$ & $\begin{array}{l}\text { Anthropometric } \\
\text { adiposity/obesity } \\
\text { measures } \\
\text { (BMI, WC, } \\
\text { WHR, WHtR, } \\
\text { BF\%) }\end{array}$ & $\begin{array}{l}\text { Inflammatory } \\
\text { markers (CRP, IL- } \\
6, \text { TNF- } \alpha \text { ) } \\
\text { measurement site, } \\
\text { assay, CV }\end{array}$ & Results & Analysis and significance & $\begin{array}{l}\text { Adjustments } \\
\text { for } \\
\text { covariates }\end{array}$ \\
\hline $\begin{array}{l}\text { Bo, } \\
\text { Raspo, } \\
\text { Morra, } \\
\text { Isaia et } \\
\text { al, 2004, } \\
\text { Italy }\end{array}$ & $\begin{array}{l}\text { To investigate } \\
\text { the } \\
\text { relationships } \\
\text { between body } \\
\text { fat, CRP levels } \\
\text { and metabolic } \\
\text { variables in } \\
\text { healthy, non- } \\
\text { obese sons of } \\
\text { patients } \\
\text { affected } \\
\text { by MS. }\end{array}$ & $\begin{array}{l}\mathrm{N}=85(\mathrm{M}) \\
\text { Age } 31.5 \pm 7.5 \mathrm{y} \\
\text { BMI } 23.8 \pm 3.5 \\
\text { WC } 86.8 \pm 9.9 \mathrm{~cm} \\
\text { WHR } 0.9 \pm 0.1 \\
\text { CRP }(\text { Median }(\mathrm{IQR})) \\
0.65(0.25-1.02) \mathrm{mg} / \mathrm{L}\end{array}$ & $\begin{array}{l}\text { Healthy, } \\
\text { non-obese } \\
\text { without } \\
\text { overt MS } \\
\text { from } \\
\text { among the } \\
\text { sons of MS } \\
\text { patient at } \\
\text { the Lipid } \\
\text { Clinic of } \\
\text { the } \\
\text { Department } \\
\text { of } \\
\text { Geriatrics } \\
\text { of a } \\
\text { University } \\
\text { teaching } \\
\text { hospital in } \\
\text { Turin }\end{array}$ & $\begin{array}{l}\text { Cross- } \\
\text { sectional } \\
\text { Study } \\
\text { period: } \\
\text { not } \\
\text { reported }\end{array}$ & $\begin{array}{l}\text { BMI }\left(\mathrm{kg} / \mathrm{m}^{2}\right) \\
\text { WC }(\mathrm{cm}) \\
\text { measured } \\
\text { midway } \\
\text { between the } \\
\text { lower margin } \\
\text { of the last rib } \\
\text { and the iliac } \\
\text { crest } \\
\text { WHR } \\
\text { Hip }(\mathrm{cm}): \\
\text { measured around } \\
\text { the pelvis at the } \\
\text { point of } \\
\text { maximum } \\
\text { buttock } \\
\text { protrusion }\end{array}$ & $\begin{array}{l}\text { CRP (mg/L) } \\
\text { Plasma } \\
\text { HS- } \\
\text { immunoassay } \\
\text { with a } \\
\text { monoclonal } \\
\text { antibody coated } \\
\text { with } \\
\text { polystyrene } \\
\text { particles } \\
\text { CV= Not } \\
\text { reported } \\
\text { Overnight fast }\end{array}$ & $\begin{array}{l}\text { CRP levels were } \\
\text { significantly } \\
\text { associated with } \\
\text { the measures of } \\
\text { obesity (BMI, } \\
\text { WC and WHR) } \\
(p<0.001) \text { in } \\
\text { healthy, non- } \\
\text { obese sons of MS } \\
\text { patients. }\end{array}$ & $\begin{array}{l}\text { Univariate linear } \\
\text { regression } \\
\text { CRP (log) } \\
\text { BMI: } r=0.525 \\
(p<0.0001) \\
\text { WC: } r=0.617 \\
(p<0.0001) \\
\text { WHR: } r=0.486 \\
(p<0.0001)\end{array}$ & No \\
\hline
\end{tabular}




\begin{tabular}{|c|c|c|c|c|c|c|c|c|c|}
\hline $\begin{array}{l}\text { Author, } \\
\text { year, } \\
\text { country }\end{array}$ & Purpose & \multicolumn{2}{|c|}{$\begin{array}{l}\text { Participants } \\
\text { (N/sex/age/adiposity/inflammatory } \\
\text { markers: mean } \pm \mathrm{SD} \text { ), } \\
\text { setting/location }\end{array}$} & $\begin{array}{l}\text { Design, } \\
\text { study } \\
\text { period }\end{array}$ & $\begin{array}{l}\text { Anthropometric } \\
\text { adiposity } \\
\text { measures } \\
\text { (BMI, WC, } \\
\text { WHR, WHtR, } \\
\text { BF\%) }\end{array}$ & $\begin{array}{l}\text { Inflammatory } \\
\text { markers } \\
\text { (CRP, IL-6, TNF- } \alpha \text { ) } \\
\text { measurement site, } \\
\text { assay, CV }\end{array}$ & Results & Analysis and significance & $\begin{array}{l}\text { Adjustments } \\
\text { for } \\
\text { covariates }\end{array}$ \\
\hline $\begin{array}{l}\text { Bo, } \\
\text { Raspo, } \\
\text { Morra, } \\
\text { Cassader } \\
\text { et al, } \\
2004 \text {, } \\
\text { ltaly }\end{array}$ & $\begin{array}{l}\text { To evaluate } \\
\text { whether body fat } \\
\text { is an } \\
\text { independent } \\
\text { predictor of hs- } \\
\text { CRP levels in } \\
\text { healthy, young } \\
\text { adult non-obese } \\
\text { subjects. }\end{array}$ & $\begin{array}{l}\mathrm{N}=87(\mathrm{M}) \\
\text { Age } 30 \pm 3.5 \mathrm{y} \\
\text { Healthy, non-obese } \\
\text { young adults } \\
\\
\text { BMI } 24.1 \pm 3.5 \\
\text { WC } 86.8 \pm 9.9 \mathrm{~cm} \\
\text { WHR } 0.9 \pm 0.1 \\
\mathrm{CRP}(\mathrm{Median}(\mathrm{IQR})) \\
0.65(0.25-1.02) \mathrm{mg} / \mathrm{dL}\end{array}$ & $\begin{array}{l}\text { Volunteers } \\
\text { of young } \\
\text { adults men } \\
\text { of the } \\
\text { hospital } \\
\text { staff at the } \\
\text { Lipid } \\
\text { Clinic of } \\
\text { the } \\
\text { Department } \\
\text { of } \\
\text { Geriatrics } \\
\text { of a } \\
\text { University } \\
\text { teaching } \\
\text { hospital in } \\
\text { Turin. }\end{array}$ & $\begin{array}{l}\text { Cross- } \\
\text { sectional } \\
\text { Study } \\
\text { period: } \\
\text { Not } \\
\text { reported }\end{array}$ & $\begin{array}{l}\text { BMI }\left(\mathrm{kg} / \mathrm{m}^{2}\right) \\
\text { WC }(\mathrm{cm}): \\
\text { Not reported } \\
\text { WHR and hip: } \\
\text { Not reported }\end{array}$ & $\begin{array}{l}\text { Hs-CRP }(\mathrm{mg} / \mathrm{L}) \\
\text { Plasma } \\
\text { HS- } \\
\text { immunoassay } \\
\text { with a } \\
\text { monoclonal } \\
\text { antibody coated } \\
\text { with } \\
\text { polystyrene } \\
\text { particles } \\
\text { CV=Not reported } \\
\text { Overnight fasting }\end{array}$ & $\begin{array}{l}\text { Hs-CRP level was } \\
\text { strongly } \\
\text { associated with } \\
\text { BMI, WC and } \\
\text { WHR } \\
(p<0.001) .\end{array}$ & $\begin{array}{l}\text { Univariate linear } \\
\text { regression } \\
\text { CRP }(\log ) \\
\text { BMI: } \beta=0.147 \\
(p<0.001) \\
\text { WC: } \beta=0.061 \\
(p<0.001) \\
\text { WHR: } \beta=7.454 \\
(p<0.001)\end{array}$ & No \\
\hline $\begin{array}{l}\text { Brydon } \\
\text { et al., } \\
2008 \text {, } \\
\text { UK }\end{array}$ & $\begin{array}{l}\text { To investigate } \\
\text { the relationship } \\
\text { between } \\
\text { measures of } \\
\text { adiposity and } \\
\text { cytokine, CV } \\
\text { and } \\
\text { neuroendocrine } \\
\text { response to } \\
\text { stress in healthy } \\
\text { young women. }\end{array}$ & $\begin{array}{l}\mathrm{N}=67(\mathrm{~F}) \\
\text { Age } 21.3 \mathrm{y} \\
\quad(18-25 \mathrm{y}) \\
\text { White: } 66.7 \%, \\
\text { Non-white: } \\
33.3 \% \\
\text { BMI } 23.2 \pm 3.1 \\
\text { WC } 70.3 \pm 7.9 \mathrm{~cm} \\
\text { BF } 25.7 \pm 5.4 \% \\
\text { IL-6 } 0.71 \pm 0.4 \mathrm{pg} / \mathrm{mL}\end{array}$ & $\begin{array}{l}\text { Volunteers } \\
\text { of healthy } \\
\text { females in } \\
\text { the } \\
\text { University } \\
\text { College } \\
\text { London }\end{array}$ & $\begin{array}{l}\text { Cross- } \\
\text { sectional } \\
\text { Study } \\
\text { period: } \\
\text { Not } \\
\text { reported }\end{array}$ & $\begin{array}{l}\text { BMI }\left(\mathrm{kg} / \mathrm{m}^{2}\right) \\
\text { WC }(\mathrm{cm}): \\
\text { measured } \\
\text { midway between } \\
\text { the lowest rib } \\
\text { and iliac crest } \\
\text { BF\%: } \\
\text { measured by } \\
\text { bioelectrical } \\
\text { impedance } \\
\text { and \% fat was } \\
\text { calculated as } \\
\text { fat wt divided } \\
\text { by total body } \\
\text { wt (fat + lean) } \\
\text { at baseline }\end{array}$ & $\begin{array}{l}\text { IL-6 }(\mathrm{pg} / \mathrm{mL}): \\
\text { At baseline } \\
\text { Plasma } \\
\text { ELISA } \\
\text { Intra-assay CV } \\
=5.3 \% \\
\text { Inter-assay CV } \\
=9.2 \% \\
\text { Non-fasting }\end{array}$ & $\begin{array}{l}\text { IL-6 was } \\
\text { significantly } \\
\text { related to BF\%, } \\
\text { and BMI at } \\
\text { baseline. }\end{array}$ & $\begin{array}{l}\text { Partial correlation } \\
\text { (at baseline) } \\
\text { BMI: } r=0.31(p<0.05) \\
\text { WC: } r=0.17(p=\text { NS) } \\
\text { BF\%: } r=0.28 \\
\quad(p<0.05)\end{array}$ & $\begin{array}{l}\text { Adjusted for } \\
\text { age, ethnicity, } \\
\text { and smoking } \\
\text { status }\end{array}$ \\
\hline
\end{tabular}




\begin{tabular}{|c|c|c|c|c|c|c|c|c|c|}
\hline $\begin{array}{l}\text { Author, } \\
\text { year, } \\
\text { country }\end{array}$ & Purpose & $\begin{array}{l}\text { Participants } \\
\text { (N/sex/age/adiposity/in } \\
\text { markers: mean } \pm \text { SD), } \\
\text { setting/location }\end{array}$ & lammatory & $\begin{array}{l}\text { Design, } \\
\text { study } \\
\text { period }\end{array}$ & $\begin{array}{l}\text { Anthropometric } \\
\text { adiposity } \\
\text { measures } \\
\text { (BMI, WC, } \\
\text { WHR, WHtR, } \\
\text { BF\%) }\end{array}$ & $\begin{array}{l}\text { Inflammatory } \\
\text { markers } \\
\text { (CRP, IL-6, TNF- } \alpha \text { ) } \\
\text { measurement site, } \\
\text { assay, CV }\end{array}$ & Results & Analysis and significance & $\begin{array}{l}\text { Adjustments } \\
\text { for } \\
\text { covariates }\end{array}$ \\
\hline $\begin{array}{l}\text { Hermsdo } \\
\text { rff et al., } \\
2012 \text {, } \\
\text { Brazil } \\
\text { and } \\
\text { Spain }\end{array}$ & $\begin{array}{l}\text { To assess the } \\
\text { potential } \\
\text { contribution of } \\
\text { gender, body fat } \\
\text { distribution, and } \\
\text { their interactions } \\
\text { to some } \\
\text { inflammatory } \\
\text { marker } \\
\text { concentrations } \\
\text { (CRP, } \\
\text { complement } \\
\text { factor } 3 \text { (C3), } \\
\text { and } \\
\text { ceruloplasmin } \\
\text { (Cp) in young } \\
\text { adults. }\end{array}$ & $\begin{array}{l}\mathrm{N}=317 \\
(\mathrm{M} / \mathrm{F}=122 / 195) \\
\text { Age: } 22 \pm 3 \mathrm{y} \\
(18-35 \mathrm{y}) \\
\text { BMI }(\mathrm{M}+\mathrm{F}) 22.1 \pm 2.8 \\
\mathrm{BF}(\mathrm{M}+\mathrm{F}) 26.1 \pm 6.4 \% \\
\mathrm{CRP}(\mathrm{M}+\mathrm{F})(\mathrm{Median} \\
(\mathrm{IQR})) \\
0.83(0.47-1.58) \\
\mathrm{mg} / \mathrm{dL}\end{array}$ & $\begin{array}{l}\text { Volunteers } \\
\text { from the } \\
\text { Federal } \\
\text { University } \\
\text { of Viçosa, } \\
\text { Brazil } \\
(\mathrm{M} / \mathrm{F}= \\
67 / 92) \text { and } \\
\text { the } \\
\text { University } \\
\text { of Navarra, } \\
\text { Spain (M/F } \\
=55 / 103)\end{array}$ & $\begin{array}{l}\text { Cross- } \\
\text { sectional } \\
\text { Study } \\
\text { period: } \\
\text { Not } \\
\text { reported } \\
\text { clearly }\end{array}$ & $\begin{array}{l}\text { BF\%: estimated } \\
\text { by the equations } \\
\text { using four } \\
\text { skinfold } \\
\text { thickness } \\
\text { (biceps, triceps, } \\
\text { subscapular, and } \\
\text { suprailiac) }\end{array}$ & $\begin{array}{l}\mathrm{CRP}(\mathrm{mg} / \mathrm{L}) \\
\text { Plasma } \\
\text { ELISA } \\
\text { Intra-assay CV } \\
<10 \% \\
\text { Inter-assay CV } \\
<10 \% \\
\text { Overnight fast }\end{array}$ & $\begin{array}{l}\text { BF significantly } \\
\text { presented } R^{2} \text { for } \\
\text { CRP }(11 \%) \text { in } \\
\text { both sex. BF } \\
\text { significantly } \\
\text { presented CRP in } \\
\text { men }(13 \%) \text { and } \\
\text { women }(7 \%) .\end{array}$ & $\begin{array}{l}\text { Multiple regression } \\
\text { analyses } \\
\text { CRP }(\log )(\mathrm{M}+\mathrm{F}) \\
\text { BF: } \\
R^{2}=0.11(p<0.001) \\
\text { B-coefficient }(95 \% \mathrm{CI}) \\
=0.023(0.016 ; 0.030) \\
(p<0.001) \\
\text { CRP }(\log )(\mathrm{M}) \\
\text { BF: } \\
R^{2}=0.13(p<0.001) \\
\text { B-coefficient }(95 \% \mathrm{CI}) \\
=0.035(0.019 ; 0.051) \\
(p<0.001) \\
\text { CRP }(\log )(\mathrm{F}) \\
\text { BF: } \\
R^{2}=0.07(p<0.001) \\
\text { B-coefficient }(95 \% \mathrm{CI}) \\
=0.032(0.014 ; 0.042) \\
(p<0.001)\end{array}$ & $\begin{array}{l}\text { Multiple } \\
\text { linear } \\
\text { regression } \\
\text { models were } \\
\text { performed for } \\
\text { sex } \\
\text { separately. }\end{array}$ \\
\hline $\begin{array}{l}\text { Hermsdo } \\
\text { rff et al, } \\
2011 \text {, } \\
\text { Spain }\end{array}$ & $\begin{array}{l}\text { To assess the } \\
\text { potential } \\
\text { association of } \\
\text { some selected } \\
\text { plasma } \\
\text { inflammatory } \\
\text { marker } \\
\text { concentrations } \\
\text { with adiposity } \\
\text { (total and } \\
\text { central) and }\end{array}$ & $\begin{array}{l}\mathrm{N}=154 \\
(\mathrm{M} / \mathrm{F}=53 / 101) \\
\text { Age } 21 \pm 3 \mathrm{y} \\
\\
\mathrm{BMI}(\mathrm{M}+\mathrm{F}) \\
22.1 \pm 2.7 \\
\mathrm{WHR}(\mathrm{M}+\mathrm{F}) \\
0.74 \pm 0.06 \\
\mathrm{BF}(\mathrm{M}+\mathrm{F}) \\
20.0 \pm 6.5 \% \\
\mathrm{CRP}(\mathrm{M}+\mathrm{F})\end{array}$ & $\begin{array}{l}\text { Volunteers } \\
\text { from the } \\
\text { University } \\
\text { of Navarra, } \\
\text { Spain }\end{array}$ & $\begin{array}{l}\text { Cross- } \\
\text { sectional } \\
\text { Study } \\
\text { period: } \\
\text { Not } \\
\text { reported } \\
\text { clearly }\end{array}$ & $\begin{array}{l}\text { WC }(\mathrm{cm}): \\
\text { measured } \\
\text { midway } \\
\text { between the } \\
\text { lowest rib and } \\
\text { the iliac crest } \\
\text { Hip }(\mathrm{cm}): \\
\text { Measured at the } \\
\text { maximal hip } \\
\text { circumference, } \\
\text { without gluteal }\end{array}$ & $\begin{array}{l}\text { CRP }(\mathrm{mg} / \mathrm{L}) \\
\text { Plasma } \\
\text { ELISA } \\
\text { Intra-assay CV } \\
<10 \% \\
\text { Inter-assay CV } \\
<10 \% \\
\\
\text { IL-6 (pg/mL) } \\
\text { Plasma }\end{array}$ & $\begin{array}{l}\text { Those subjects } \\
\text { with higher WC } \\
\text { and WHR } \\
\text { (central } \\
\text { adiposity) } \\
\text { Showed higher } \\
\text { CRP and IL-6 } \\
(p<0.05) \text {. } \\
\text { Only IL-6 } \\
\text { concentration }\end{array}$ & $\begin{array}{l}\text { Multiple linear regression } \\
\text { for trend ( } r \text { was not } \\
\text { reported } p \text { for trend (WC, } \\
\text { WHR, and BF\% were } \\
\text { categorized into tertiles to } \\
\text { assess trends.), from linear } \\
\text { regression model adjusted } \\
\text { for covariates) } \\
\text { CRP } \\
\text { WC }(p=0.015)\end{array}$ & $\begin{array}{l}\text { Adjusted for } \\
\text { age, sex, } \\
\text { smoking, and } \\
\text { physical } \\
\text { activity. }\end{array}$ \\
\hline
\end{tabular}




\begin{tabular}{|c|c|c|c|c|c|c|c|c|c|}
\hline \multirow[t]{2}{*}{$\begin{array}{l}\text { Author, } \\
\text { year, } \\
\text { country }\end{array}$} & \multirow{2}{*}{$\begin{array}{l}\text { Purpose } \\
\text { metabolic } \\
\text { features in } \\
\text { apparently } \\
\text { healthy young } \\
\text { adults. }\end{array}$} & \multicolumn{2}{|c|}{$\begin{array}{l}\text { Participants } \\
\text { (N/sex/age/adiposity/inflammatory } \\
\text { markers: mean } \pm \mathrm{SD}) \\
\text { setting/location }\end{array}$} & \multirow[t]{2}{*}{$\begin{array}{l}\text { Design, } \\
\text { study } \\
\text { period }\end{array}$} & \multirow{2}{*}{$\begin{array}{l}\text { Anthropometric } \\
\text { adiposity } \\
\text { measures } \\
\text { (BMI, WC, } \\
\text { WHR, WHtR, } \\
\text { BF\%) } \\
\text { contraction. } \\
\text { WHR } \\
\text { BF\%: } \\
\text { measured by a } \\
\text { bioelectric } \\
\text { impedance } \\
\text { and sum of } \\
\text { four SF } \\
\text { thickness: } \\
\text { biceps, triceps, } \\
\text { subscapular, } \\
\text { and suprailiac) }\end{array}$} & \multirow{2}{*}{$\begin{array}{l}\text { Inflammatory } \\
\text { markers } \\
\text { (CRP, IL-6, TNF- } \alpha \text { ) } \\
\text { measurement site, } \\
\text { assay, CV } \\
\\
\text { ELISA } \\
\text { Intra-assay CV } \\
<10 \% \\
\text { Inter-assay CV } \\
<10 \% \\
\text { Overnight fast }\end{array}$} & \multirow{2}{*}{$\begin{array}{l}\text { Results } \\
\\
\text { was positively } \\
\text { associated with } \\
\text { total BF\% } \\
\text { ( } p<0.05 \text { ). } \\
\text { Central adiposity- } \\
\text { related indicators } \\
\text { (WC/WHR) } \\
\text { correlated better } \\
\text { than those } \\
\text { assessing total } \\
\text { adiposity with } \\
\text { plasma } \\
\text { proinflammatory } \\
\text { markers. }\end{array}$} & \multirow{2}{*}{$\begin{array}{l}\text { Analysis and significance } \\
\\
\text { WHR }(p=0.020) \\
\text { BF\% }(p=0.053) \\
\text { IL-6 } \\
\text { WC }(p=0.001) \\
\text { WHR }(p=0.002) \\
\text { BF\% }(p=0.001)\end{array}$} & \multirow{2}{*}{$\begin{array}{l}\text { Adjustments } \\
\text { for } \\
\text { covariates }\end{array}$} \\
\hline & & $\begin{array}{l}\text { (Median (IQR)) } \\
0.8(0.6-1.4) \mathrm{mg} / 1 \\
\text { IL-6 (M+F) } \\
\text { (Median (IQR)) } \\
1.1(0.8-1.5) \mathrm{pg} / 1\end{array}$ & & & & & & & \\
\hline $\begin{array}{l}\text { McDade } \\
\text { et al, } \\
2009 \text {, } \\
\text { Philippin } \\
\text { es }\end{array}$ & $\begin{array}{l}\text { To investigate } \\
\text { the predictors of } \\
\text { CRP in young } \\
\text { adults living in } \\
\text { the Philippines. }\end{array}$ & $\begin{array}{l}\mathrm{N}=1,648 \\
(\mathrm{M} / \mathrm{F}=916 / 732) \\
\text { Age } 20.9 \pm 0.3 \mathrm{y} \\
\\
\text { BMI }(\mathrm{M}+\mathrm{F}) 20.7 \pm 3.2 \\
\text { WC }(\mathrm{M}+\mathrm{F}) \\
70.3 \pm 7.8 \mathrm{~cm} \\
3 \mathrm{SF}(\mathrm{M}+\mathrm{F}) \\
48.5 \pm 22.3 \mathrm{~mm} \\
\text { CRP }(\mathrm{M}+\mathrm{F})(\mathrm{Median} \\
(\mathrm{IQR})) \\
0.2(0.1,0.9) \mathrm{mg} / \mathrm{L}\end{array}$ & $\begin{array}{l}\text { The Cebu } \\
\text { Longitudin } \\
\text { al Health } \\
\text { and } \\
\text { Nutrition } \\
\text { Survey } \\
\text { follow up } \\
\text { Cebu, } \\
\text { metropolita } \\
\text { n area }\end{array}$ & $\begin{array}{l}\text { Cross- } \\
\text { sectional } \\
\text { In } 2005\end{array}$ & $\begin{array}{l}\text { BMI }\left(\mathrm{kg} / \mathrm{m}^{2}\right) \\
\text { WC }(\mathrm{cm}): \\
\text { Not reported } \\
\text { 3SF thickness: } \\
\text { triceps, } \\
\text { subscapular, } \\
\text { and suprailirac }\end{array}$ & $\begin{array}{l}\text { CRP (mg/L) } \\
\text { Plasma } \\
\text { Hs-immuno- } \\
\text { turbidimetric } \\
\text { method } \\
\text { Intra-assay CV } \\
=\text { Not reported } \\
\text { Inter-assay CV } \\
<7.6 \% \\
\text { Overnight fast } \\
\text { Cut-off level = } \\
3.0 \text { mg/L } \\
>3.0 \text { (high) } \\
\leq 3.0 \text { (low or } \\
\text { normal) } \\
>10 \text { mg/L: } \\
\text { excluded due to }\end{array}$ & $\begin{array}{l}\text { In female, BMI } \\
\text { and WC were } \\
\text { significant } \\
\text { predictors of } \\
\text { elevated CRP ( } p \text { : } \\
\text { not reported) } \\
\text { although WC } \\
\text { was a strong } \\
\text { predictor when } \\
\text { all measures } \\
\text { were considered } \\
\text { simultaneously. } \\
\text { A } 1 \mathrm{~cm} \text { increase } \\
\text { In WC was } \\
\text { associated with a } \\
6.0 \% \text { increase in } \\
\text { the likelihood of } \\
\text { CRP }>3 \mathrm{mg} / \mathrm{L}\end{array}$ & $\begin{array}{l}\text { A series of maximum } \\
\text { likelihood logistic } \\
\text { regression } \\
\text { : Detailed data were } \\
\text { not reported }\end{array}$ & No \\
\hline
\end{tabular}




\begin{tabular}{|c|c|c|c|c|c|c|c|c|c|}
\hline \multirow[t]{2}{*}{$\begin{array}{l}\text { Author, } \\
\text { year, } \\
\text { country }\end{array}$} & Purpose & \multicolumn{2}{|c|}{$\begin{array}{l}\text { Participants } \\
\text { (N/sex/age/adiposity/inflammatory } \\
\text { markers: mean } \pm \text { SD), } \\
\text { setting/location }\end{array}$} & $\begin{array}{l}\text { Design, } \\
\text { study } \\
\text { period }\end{array}$ & $\begin{array}{l}\text { Anthropometric } \\
\text { adiposity } \\
\text { measures } \\
\text { (BMI, WC, } \\
\text { WHR, WHtR, } \\
\text { BF\%) }\end{array}$ & $\begin{array}{l}\text { Inflammatory } \\
\text { markers } \\
\text { (CRP, IL-6, TNF- } \alpha \text { ) } \\
\text { measurement site, } \\
\text { assay, CV }\end{array}$ & Results & Analysis and significance & $\begin{array}{l}\text { Adjustments } \\
\text { for } \\
\text { covariates }\end{array}$ \\
\hline & & & & & & $\begin{array}{l}\text { infectious } \\
\text { diseases }\end{array}$ & $\begin{array}{l}\text { (OR: } 1.060, p< \\
0.001) . \\
\text { In males, SF } \\
\text { thickeness was } \\
\text { significant in } \\
\text { predicting } \\
\text { elevated CRP. } \\
\text { A 1 mm increase } \\
\text { in the sum of } \\
3 S F \text { measures } \\
\text { was associated } \\
\text { with al.1\% } \\
\text { increase in } \\
\text { the likelihood of } \\
\text { elevated CRP } \\
\text { (OR: } 1.011, p= \\
0.09) .\end{array}$ & & \\
\hline $\begin{array}{l}\text { McDade } \\
\text { et al, } \\
2011 \text {, } \\
\text { Philippin } \\
\text { es }\end{array}$ & $\begin{array}{l}\text { To report } \\
\text { concentrations } \\
\text { of IL-6 and to } \\
\text { evaluate } \\
\text { adiposity, } \\
\text { infectious, and } \\
\text { socioeconomic } \\
\text { predictors of } \\
\text { individual } \\
\text { variation in IL-6 } \\
\text { in young adults. }\end{array}$ & $\begin{array}{l}\mathrm{N}=1,569 \\
(\mathrm{M} / \mathrm{F}=866 / 703) \\
\text { Age } 20.9 \pm 0.3 \mathrm{y} \\
\quad(20-22 \mathrm{y}) \\
\\
\text { BMI }(\mathrm{M}+\mathrm{F}) 20.7 \pm 3.2 \\
\mathrm{IL}-6(\mathrm{M}+\mathrm{F})(\text { Median } \\
(\mathrm{IQR})) \\
1.00(0.28,3.21) \\
\mathrm{pg} / \mathrm{mL}\end{array}$ & $\begin{array}{l}\text { The Cebu } \\
\text { Longitudin } \\
\text { al Health } \\
\text { and } \\
\text { Nutrition } \\
\text { Survey } \\
\text { follow up } \\
\text { Cebu, } \\
\text { metropolita } \\
\mathrm{n} \text { area }\end{array}$ & $\begin{array}{l}\text { Cross- } \\
\text { sectional } \\
\text { In } 2005\end{array}$ & BMI $\left(\mathrm{kg} / \mathrm{m}^{2}\right)$ & $\begin{array}{l}\mathrm{IL}-6(\mathrm{pg} / \mathrm{mL}) \\
\text { Plasma } \\
\text { Hs-multiplex } \\
\text { Immunoassay } \\
\text { Intra-assay CV } \\
=13.3 \% \\
\text { Inter-assay CV } \\
\text { for low (14.7\%) } \\
\text { and high (12.4\%) } \\
\text { Overnight fast }\end{array}$ & $\begin{array}{l}\text { BMI was } \\
\text { positively } \\
\text { associated with } \\
\text { IL-6 } \\
\text { concentration } \\
(p<0.05) \text {. }\end{array}$ & $\begin{array}{l}\text { Tobit regression model } \\
\text { IL-6 }(\log ) \\
\text { BMI: } \mathrm{B}=0.039 \\
\quad(\mathrm{SE}=0.016, p<0.05)\end{array}$ & $\begin{array}{l}\text { Adjusted for } \\
\text { sex }\end{array}$ \\
\hline
\end{tabular}




\begin{tabular}{|c|c|c|c|c|c|c|c|c|c|}
\hline $\begin{array}{l}\text { Author, } \\
\text { year, } \\
\text { country }\end{array}$ & Purpose & $\begin{array}{l}\text { Participants } \\
\text { (N/sex/age/adiposity/in } \\
\text { markers: mean } \pm \text { SD), } \\
\text { setting/location }\end{array}$ & lammatory & $\begin{array}{l}\text { Design, } \\
\text { study } \\
\text { period }\end{array}$ & $\begin{array}{l}\text { Anthropometric } \\
\text { adiposity } \\
\text { measures } \\
\text { (BMI, WC, } \\
\text { WHR, WHtR, } \\
\text { BF\%) }\end{array}$ & $\begin{array}{l}\text { Inflammatory } \\
\text { markers } \\
\text { (CRP, IL-6, TNF- } \alpha \text { ) } \\
\text { measurement site, } \\
\text { assay, CV }\end{array}$ & Results & Analysis and significance & $\begin{array}{l}\text { Adjustments } \\
\text { for } \\
\text { covariates }\end{array}$ \\
\hline $\begin{array}{l}\text { Mills et } \\
\text { al, 2008, } \\
\text { USA }\end{array}$ & $\begin{array}{l}\text { To determine } \\
\text { the unique } \\
\text { contributions of } \\
\text { metabolic } \\
\text { factors as } \\
\text { predictors of } \\
\text { CRP and IL- } 6 \text { in } \\
\text { healthy } \\
\text { younger-aged } \\
\text { adults. }\end{array}$ & $\begin{array}{l}\mathrm{N}=175 \\
(\mathrm{M} / \mathrm{F}=83 / 92) \\
\text { AA }=28 \\
\text { Asian }=56 \\
\text { White }=68 \\
\text { Hispanic }=23 \\
\text { Age } 30.4 \pm 4.8 \mathrm{y} \\
\quad(22-39 \mathrm{y}) \\
\\
\text { BMI(M+F) } 24.4 \pm 3.35 \\
\text { WHR }(\mathrm{M}+\mathrm{F}) \\
0.823 \pm 0.07 \\
\mathrm{CRP}(\mathrm{M}+\mathrm{F}) \\
0.855 \pm 1.24 \mathrm{mg} / \mathrm{L} \\
\text { IL-6 }(\mathrm{M}+\mathrm{F}) \\
0.864 \pm 0.75 \mathrm{pg} / \mathrm{mL}\end{array}$ & $\begin{array}{l}\text { Consecutiv } \\
\text { e sample, } \\
\text { all } \\
\text { volunteers } \\
\text { were } \\
\text { employed } \\
\text { in full-time } \\
\text { day shifts } \\
\text { at the } \\
\text { University } \\
\text { of } \\
\text { California, } \\
\text { Los } \\
\text { Angeles or } \\
\text { the } \\
\text { surroundin } \\
\text { g Los } \\
\text { Angeles } \\
\text { area }\end{array}$ & $\begin{array}{l}\text { Cross- } \\
\text { sectional } \\
\text { (Design: } \\
\text { not } \\
\text { reported) }\end{array}$ & $\begin{array}{l}\text { BMI }\left(\mathrm{kg} / \mathrm{m}^{2}\right) \\
\text { WHR and hip } \\
\text { Not reported }\end{array}$ & $\begin{array}{l}\text { CRP (mg/L) } \\
\text { Plasma } \\
\text { Hs Denka- } \\
\text { Seiken assay } \\
\text { Intra-and inter- } \\
\text { assay CV }< \\
10 \% \\
\text { Sensitivity }< \\
0.05 \mathrm{mg} / \mathrm{L} \\
\\
\text { IL-6 (pg/mL) } \\
\text { Plasma } \\
\text { ELISA } \\
\text { Intra-and inter- } \\
\text { assay CV }< \\
10 \% \\
\text { Sensitivity }< \\
0.72 \text { pg/ml } \\
\text { Overnight fast }\end{array}$ & $\begin{array}{l}\text { CRP was } \\
\text { positively } \\
\text { associated with } \\
\text { BMI and WHR } \\
(p<0.05) \text {. } \\
\text { IL-6 was positively } \\
\text { associated with } \\
\text { WHR }(p<0.01) \text {. }\end{array}$ & $\begin{array}{l}\text { Univarate correlation } \\
\text { CRP } \\
\text { BMI: } r=0.340 \\
(p<0.01) \\
\text { WHR: } r=0.141 \\
(P<0.05) \\
\\
\\
\text { IL-6 } \\
\text { BMI: } r=0.070 \\
(p=N S) \\
\text { WHR: } r=0.306 \\
(p<0.01)\end{array}$ & No \\
\hline $\begin{array}{l}\text { Morrison } \\
\text { et al, } \\
2011 \text {, } \\
\text { USA }\end{array}$ & $\begin{array}{l}\text { To assess hs- } \\
\text { CRP tracking in } \\
\text { black and white } \\
\text { females from } \\
\text { mid-adolescence } \\
\text { to young } \\
\text { adulthood and to } \\
\text { identify factors } \\
\text { associated with } \\
\text { hs-CRP. }\end{array}$ & $\begin{array}{l}\mathrm{N}=392(\mathrm{~F}) \\
\text { Age } 26 \mathrm{y} \\
\text { Caucasian and AA } \\
\text { BMI, WC, and hs- } \\
\text { CRP were not reported }\end{array}$ & $\begin{array}{l}\text { The } \\
\text { National } \\
\text { Growth and } \\
\text { Health } \\
\text { Study } \\
\text { (NGHS), a } \\
\text { prospective } \\
\text { ly followed } \\
\text { up }\end{array}$ & $\begin{array}{l}\text { Cross- } \\
\text { sectional }\end{array}$ & $\begin{array}{l}\text { BMI }\left(\mathrm{kg} / \mathrm{m}^{2}\right) \\
\text { WC }(\mathrm{cm}): \\
\text { Not reported }\end{array}$ & $\begin{array}{l}\text { Hs-CRP (mg/L) } \\
\text { Serum } \\
\text { N hs latex } \\
\text { enhanced } \\
\text { immune- } \\
\text { nephelometric } \\
\text { assay } \\
\mathrm{CV}=\text { Not } \\
\text { Reported } \\
\text { Overnight fast }\end{array}$ & $\begin{array}{l}\text { Hs-CRP was } \\
\text { Significantly } \\
\text { correlated with } \\
\text { BMI and WC } \\
(p<0.001) .\end{array}$ & $\begin{array}{l}\text { Bivariate correlation } \\
\text { CRP }(\log ) \\
\text { BMI: } r=0.56 \\
(p<0.001) \\
\text { WC: } r=0.55 \\
(p<0.001)\end{array}$ & No \\
\hline
\end{tabular}




\begin{tabular}{|c|c|c|c|c|c|c|c|c|c|}
\hline $\begin{array}{l}\text { Author, } \\
\text { year, } \\
\text { country }\end{array}$ & Purpose & $\begin{array}{l}\text { Participants } \\
\text { (N/sex/age/adiposity/in } \\
\text { markers: mean } \pm \text { SD), } \\
\text { setting/location }\end{array}$ & Aammatory & $\begin{array}{l}\text { Design, } \\
\text { study } \\
\text { period }\end{array}$ & $\begin{array}{l}\text { Anthropometric } \\
\text { adiposity } \\
\text { measures } \\
\text { (BMI, WC, } \\
\text { WHR, WHtR, } \\
\text { BF\%) }\end{array}$ & $\begin{array}{l}\text { Inflammatory } \\
\text { markers } \\
\text { (CRP, IL-6, TNF- } \alpha \text { ) } \\
\text { measurement site, } \\
\text { assay, CV }\end{array}$ & Results & Analysis and significance & $\begin{array}{l}\text { Adjustments } \\
\text { for } \\
\text { covariates }\end{array}$ \\
\hline $\begin{array}{l}\text { Nazmi et } \\
\text { al, 2008, } \\
\text { Brazil }\end{array}$ & $\begin{array}{l}\text { To identify } \\
\text { factors } \\
\text { associated with } \\
\text { CRP levels in a } \\
\text { young adult } \\
\text { Brazilian } \\
\text { population. }\end{array}$ & $\begin{array}{l}\mathrm{N}=3,289 \\
(\mathrm{M} / \mathrm{F}= \\
1,919 / 1,370) \\
\text { Age } 22.8 \mathrm{y} \\
\quad(21.9-23.7 \mathrm{y}) \\
\text { BMI and hs-CRP were } \\
\text { not reported }\end{array}$ & $\begin{array}{l}\text { The } 1982 \\
\text { Pelotas } \\
\text { Birth } \\
\text { Cohort } \\
\text { study in the } \\
\text { city of } \\
\text { Pelotas, } \\
\text { prospective } \\
\text { ly followed } \\
\text { up }\end{array}$ & $\begin{array}{l}\begin{array}{l}\text { Cross- } \\
\text { sectional }\end{array} \\
\text { In 2004- } \\
2005\end{array}$ & $\begin{array}{l}\text { BMI }\left(\mathrm{kg} / \mathrm{m}^{2}\right) \\
\text { WC }(\mathrm{cm}): \\
\text { measured at the } \\
\text { narrowest girth } \\
\text { of the truck or } \\
\text { halfway between } \\
\text { the costal } \\
\text { margin and iliac } \\
\text { crest }\end{array}$ & $\begin{array}{l}\text { Hs-CRP (mg/L) } \\
\text { Plasma } \\
\text { automated DPC } \\
\text { (Siemens) } \\
\text { Immulite } \\
\text { Chem- } \\
\text { iluminescent } \\
\text { immunoassay } \\
\text { Intra-assay CV } \\
=10 \% \\
\text { Inter-assay CV } \\
=7 \% \\
\text { Sensitivity } \\
<0.1 \mathrm{mg} / \mathrm{L} \\
\text { Non-fasting }\end{array}$ & $\begin{array}{l}\text { Hs-CRP was } \\
\text { significantly } \\
\text { associated with } \\
\text { BMI and WC in } \\
\text { men and women } \\
(p<0.001) .\end{array}$ & $\begin{array}{c}\text { Crude analyses } \\
\text { (p-values for trend by } \\
\text { linear regression) } \\
\text { Hs-CRP (log) } \\
\text { BMI (M): } \beta(95 \% \mathrm{CI}) \\
<18.5: \beta=0.57 \\
(0.43-0.75) \\
18.5-24.9: 1(\mathrm{ref}) \\
25.0-29.9: \beta=1.54 \\
(1.34-1.76) \\
\geq 30.0: \beta=3.03 \\
(2.44-3.76) \\
(p<0.001) \\
\text { WC (M): } 1(\text { ref }) \\
\geq 94: \beta=2.33 \\
(1.94-2.82) \\
(p<0.001) \\
\\
\text { BMI (F): } \beta(95 \% \mathrm{CI}) \\
<18.5: \beta=0.73 \\
(0.56-0.96) \\
18.5-24.9: 1(\text { ref }) \\
25.0-29.9: \beta=1.68 \\
(1.37-2.05) \\
\geq 30.0: \beta=3.34 \\
(2.56-4.34) \\
(p<0.001) \\
\text { WC (F): } 1(\mathrm{ref}) \\
\geq 80: \beta=2.29 \\
(1.93-2.74) \\
(p<0.001)\end{array}$ & $\begin{array}{l}\text { Adjusted for } \\
\text { skin color, } \\
\text { age, family } \\
\text { income, and } \\
\text { years of } \\
\text { education }\end{array}$ \\
\hline
\end{tabular}




\begin{tabular}{|c|c|c|c|c|c|c|c|c|c|}
\hline $\begin{array}{l}\text { Author, } \\
\text { year, } \\
\text { country }\end{array}$ & Purpose & $\begin{array}{l}\text { Participants } \\
\text { (N/sex/age/adiposity/in } \\
\text { markers: mean } \pm \text { SD), } \\
\text { setting/location }\end{array}$ & nammatory & $\begin{array}{l}\text { Design, } \\
\text { study } \\
\text { period }\end{array}$ & $\begin{array}{l}\text { Anthropometric } \\
\text { adiposity } \\
\text { measures } \\
\text { (BMI, WC, } \\
\text { WHR, WHtR, } \\
\text { BF\%) }\end{array}$ & $\begin{array}{l}\text { Inflammatory } \\
\text { markers } \\
\text { (CRP, IL-6, TNF- } \alpha \text { ) } \\
\text { measurement site, } \\
\text { assay, CV }\end{array}$ & Results & Analysis and significance & $\begin{array}{l}\text { Adjustments } \\
\text { for } \\
\text { covariates }\end{array}$ \\
\hline $\begin{array}{l}\text { Orri et al, } \\
2010 \text {, } \\
\text { USA }\end{array}$ & $\begin{array}{l}\text { To determine } \\
\text { the relationship } \\
\text { between } C A D \\
\text { risk factors and } \\
\text { CRP among } \\
\text { apparently } \\
\text { healthy college- } \\
\text { aged men and } \\
\text { women. }\end{array}$ & $\begin{array}{l}\mathrm{N}=30 \\
(\mathrm{M} / \mathrm{F}=16 / 14) \\
\text { Age } 22.1 \pm 3.1 \mathrm{y} \\
\\
\mathrm{BMI}(\mathrm{M}) \\
26.5 \pm 4.4 \\
\mathrm{WHR}(\mathrm{M}) \\
0.83 \pm 0.05 \\
\mathrm{BF}(\mathrm{M}) \\
14.5 \pm 6.5 \% \\
\mathrm{CRP}(\mathrm{M}) \\
0.55 \pm 0.51 \mathrm{mg} / \mathrm{L} \\
\mathrm{BMI}(\mathrm{F}) \\
24.2 \pm 1.5 \\
\mathrm{WHR}(\mathrm{F}) \\
0.73 \pm 0.03 \\
\mathrm{BF}(\mathrm{F}) \\
24.3 \pm 4.5 \% \\
\mathrm{CRP}(\mathrm{F}) \\
0.77 \pm 1.16 \mathrm{mg} / \mathrm{L}\end{array}$ & $\begin{array}{l}\text { Volunteers } \\
\text { of college } \\
\text { men and } \\
\text { women } \\
\text { (4M and } 8 \mathrm{~F} \\
\text { intercollegi } \\
\text { ate } \\
\text { athletes) }\end{array}$ & $\begin{array}{l}\text { Cross } \\
\text { sectional } \\
\text { Over } \\
2 \text { week } \\
\text { period }\end{array}$ & $\begin{array}{l}\text { BMI }\left(\mathrm{kg} / \mathrm{m}^{2}\right) \\
\text { WHR and hip: } \\
\text { Not reported in } \\
\text { detail } \\
\text { BF\%: } \\
\text { measured } \\
\text { by sum of SFs }\end{array}$ & $\begin{array}{l}\text { CRP (mg/L) } \\
\text { Plasma } \\
\text { Cardio hs-CRP } \\
\text { assay } \\
\mathrm{CV}=\text { Not } \\
\text { reported } \\
\text { Sensitivity } \\
=0.2 \mathrm{mg} / \mathrm{L} \\
\text { Overnight fast }\end{array}$ & $\begin{array}{l}\text { CRP was } \\
\text { positively } \\
\text { correlated with } \\
\text { BMI }(r=0.47, p \\
<0.05) \text { and BF\% } \\
(r=0.58, p< \\
0.05) \text {. }\end{array}$ & $\begin{array}{c}\text { Pearson correlation } \\
\text { CRP (log) } \\
\text { BMI: } r=0.47 \\
(p<0.05) \\
\text { WHR: } r=0.26 \\
(p=N S) \\
\text { BF\%: } r=0.58 \\
(p<0.05)\end{array}$ & No \\
\hline $\begin{array}{l}\text { Perez et } \\
\text { al, 2003, } \\
\text { Colombi } \\
\text { a }\end{array}$ & $\begin{array}{l}\text { To determine } \\
\text { and evaluate the } \\
\text { level of WC and } \\
\text { CRP levels in a } \\
\text { Colombian } \\
\text { population. }\end{array}$ & $\begin{array}{l}\mathrm{N}=145(\mathrm{M}) \\
\text { Age } 28.9 \mathrm{y} \\
\quad(17-38 \mathrm{y}) \\
\text { BMI } 24.08 \pm 3.97 \\
W C 83.32 \pm 10.11 \mathrm{~cm} \\
\text { WHR } 0.86 \pm 0.06 \\
\mathrm{CRP}(\mathrm{N}=145) \text { was not } \\
\text { reported. }\end{array}$ & $\begin{array}{l}\text { Young } \\
\text { healthy } \\
\text { males } \\
\text { recruited } \\
\text { from } \\
\text { different } \\
\text { levels of } \\
\text { tertiles of } \\
\text { WC the } \\
\text { health } \\
\text { service of } \\
\text { the }\end{array}$ & $\begin{array}{l}\text { Cross } \\
\text { sectional } \\
\text { Study } \\
\text { period: } \\
\text { Not } \\
\text { reported }\end{array}$ & $\begin{array}{l}\text { BMI }\left(\mathrm{kg} / \mathrm{m}^{2}\right) \\
\text { WC }(\mathrm{cm}): \\
\text { measured } \\
\text { midway } \\
\text { between the } \\
\text { iliac crest and } \\
\text { the lower } \\
\text { portion of the } \\
\text { rib cage } \\
\text { WHR and hip: } \\
\text { Not reported }\end{array}$ & $\begin{array}{l}\text { CRP (mg/L) } \\
\text { Plasma } \\
\text { Chem- } \\
\text { iluminescent } \\
\text { enzyme-labeled } \\
\text { inmmunometric } \\
\text { assay } \\
\text { CV = Not } \\
\text { Reported } \\
\text { Overnight fast }\end{array}$ & $\begin{array}{l}\text { CRP was } \\
\text { significantly } \\
\text { correlated with } \\
\text { BMI, WC and } \\
\text { WHR } \\
(p<0.00001) .\end{array}$ & $\begin{array}{c}\text { Pearson correlation } \\
\text { BMI: } r=0.08 \\
(p<0.00001) \\
\text { WC: } r=0.11 \\
(p<0.00001) \\
\text { WHR: } r=0.11 \\
(p<0.00001)\end{array}$ & No \\
\hline
\end{tabular}




\begin{tabular}{|c|c|c|c|c|c|c|c|c|c|}
\hline \multirow[t]{2}{*}{$\begin{array}{l}\text { Author, } \\
\text { year, } \\
\text { country }\end{array}$} & \multirow[t]{2}{*}{ Purpose } & \multicolumn{2}{|c|}{$\begin{array}{l}\text { Participants } \\
\text { (N/sex/age/adiposity/inflammatory } \\
\text { markers: mean } \pm \text { SD), } \\
\text { setting/location }\end{array}$} & \multirow[t]{2}{*}{$\begin{array}{l}\text { Design, } \\
\text { study } \\
\text { period }\end{array}$} & \multirow[t]{2}{*}{$\begin{array}{l}\text { Anthropometric } \\
\text { adiposity } \\
\text { measures } \\
\text { (BMI, WC, } \\
\text { WHR, WHtR, } \\
\text { BF\%) }\end{array}$} & \multirow[t]{2}{*}{$\begin{array}{l}\text { Inflammatory } \\
\text { markers } \\
\text { (CRP, IL-6, TNF-a) } \\
\text { measurement site, } \\
\text { assay, CV }\end{array}$} & \multirow[t]{2}{*}{ Results } & \multirow[t]{2}{*}{ Analysis and significance } & \multirow[t]{2}{*}{$\begin{array}{l}\text { Adjustments } \\
\text { for } \\
\text { covariates }\end{array}$} \\
\hline & & & $\begin{array}{l}\text { Colombian } \\
\text { army }\end{array}$ & & & & & & \\
\hline $\begin{array}{l}\text { Raitakari } \\
\text { et al, } \\
2005 \text {, } \\
\text { Finland }\end{array}$ & $\begin{array}{l}\text { To investigate } \\
\text { the distribution } \\
\text { of CRP and the } \\
\text { population } \\
\text { determinants of } \\
\text { CRP levels in } \\
\text { young adults. }\end{array}$ & $\begin{array}{l}\mathrm{N}=2,120 \\
(\mathrm{M} / \mathrm{F}=975 / 1,046) \\
\text { Age } 31.7 \pm 5.1 \mathrm{y} \\
(24-39 \mathrm{y}) \\
\\
\mathrm{BMI}(\mathrm{M}) \\
25.7 \pm 4.1 \\
\text { WC (M) } \\
89.6 \pm 10.7 \mathrm{~cm} \\
\text { WHR (M) } \\
0.90 \pm 0.06 \\
\mathrm{CRP}(\mathrm{M}) \\
1.43 \pm 3.26 \mathrm{mg} / \mathrm{L} \\
\\
\mathrm{BMI}(\mathrm{F}) \\
24.4 \pm 4.7 \\
\text { WC (F) } \\
78.8 \pm 11.4 \mathrm{~cm} \\
\text { WHR (F) } \\
0.79 \pm 0.06 \\
\text { CRP (F) } \\
2.01 \pm 3.90 \mathrm{mg} / \mathrm{L}\end{array}$ & $\begin{array}{l}\text { The } \\
\text { Cardiovasc } \\
\text { ular Risk in } \\
\text { Young } \\
\text { Finn Study, } \\
\text { five centre } \\
\text { follow up }\end{array}$ & $\begin{array}{l}\text { Cross- } \\
\text { sectional } \\
\text { In } 2001\end{array}$ & $\begin{array}{l}\text { BMI }\left(\mathrm{kg} / \mathrm{m}^{2}\right) \\
\text { WC }(\mathrm{cm}): \\
\text { Not reported } \\
\text { WHR and hip: } \\
\text { Not reported }\end{array}$ & $\begin{array}{l}\text { CRP (mg/L) } \\
\text { Serum } \\
\text { Hs } \\
\text { turbidimetric } \\
\text { immunoassay } \\
\text { Intra- assay CV } \\
=\text { Not reported } \\
\text { Inter-assay CV } \\
=3.33 \% \\
\text { Overnight fast }\end{array}$ & $\begin{array}{l}\text { CRP was } \\
\text { significantly } \\
\text { correlated with } \\
\text { BMI, WC, and } \\
\text { WHR in men and } \\
\text { women } \\
(p<0.0001) \text {. }\end{array}$ & $\begin{array}{r}\text { Linear regression } \\
\beta \text { : regression coefficients } \\
\text { CRP (log) } \\
\text { BMI (M): } \beta=0.0505 \\
(p<0.0001) \\
\text { WC (M): } \beta=0.0020 \\
(p<0.0001) \\
\text { WHR (M): } \beta=2.8674 \\
(p<0.0001) \\
\\
\text { BMI (F): } \beta=0.0498 \\
(p<0.0001) \\
\text { WC (F): } \beta=0.0019 \\
(p<0.0001) \\
\text { WHR (F): } \beta=2.0162 \\
(p<0.0001)\end{array}$ & No \\
\hline
\end{tabular}




\begin{tabular}{|c|c|c|c|c|c|c|c|c|c|}
\hline $\begin{array}{l}\text { Author, } \\
\text { year, } \\
\text { country }\end{array}$ & Purpose & \multicolumn{2}{|c|}{$\begin{array}{l}\text { Participants } \\
\text { (N/sex/age/adiposity/inflammatory } \\
\text { markers: mean } \pm \text { SD), } \\
\text { setting/location }\end{array}$} & $\begin{array}{l}\text { Design, } \\
\text { study } \\
\text { period }\end{array}$ & $\begin{array}{l}\text { Anthropometric } \\
\text { adiposity } \\
\text { measures } \\
\text { (BMI, WC, } \\
\text { WHR, WHtR, } \\
\text { BF\%) }\end{array}$ & $\begin{array}{l}\text { Inflammatory } \\
\text { markers } \\
\text { (CRP, IL-6, TNF-a) } \\
\text { measurement site, } \\
\text { assay, CV }\end{array}$ & Results & Analysis and significance & $\begin{array}{l}\text { Adjustments } \\
\text { for } \\
\text { covariates }\end{array}$ \\
\hline $\begin{array}{l}\text { Wang et } \\
\text { al, 2011, } \\
\text { USA }\end{array}$ & $\begin{array}{l}\text { To assess BMI } \\
\text { and BF\% as } \\
\text { measures of } \\
\text { overweight and } \\
\text { obesity and to } \\
\text { determine their } \\
\text { relationship to } \\
\text { inflammatory } \\
\text { markers in } \\
\text { university } \\
\text { students. }\end{array}$ & $\begin{array}{l}\mathrm{N}=110 \\
(\mathrm{M}: 28.2 \%, \\
\text { F: } 71.80 \%) \\
\text { Age } 21.3 \mathrm{y} \\
\quad(18-28 \mathrm{y}) \\
\\
\text { BMI }(\mathrm{M}+\mathrm{F}) \\
24.13 \pm 4.29 \\
\text { BF }(\mathrm{M}+\mathrm{F}) \\
25.23 \pm 8.64 \\
\text { CRP }(\mathrm{M}+\mathrm{F}) \\
2.34 \pm 2.44 \mu \mathrm{g} / \mathrm{mL} \\
\text { IL-6 }(\mathrm{M}+\mathrm{F}) \\
0.97 \pm 1.56 \mathrm{pg} / \mathrm{mL} \\
\text { TNF- } \alpha(\mathrm{M}+\mathrm{F}) \\
1.02 \pm 0.84 \mathrm{pg} / \mathrm{mL}\end{array}$ & $\begin{array}{l}\text { Volunteers } \\
\text { from the } \\
\text { university } \\
\text { students } \\
\text { enrolled at } \\
\text { Texas Tech } \\
\text { University, } \\
\text { Lubbock, } \\
\text { Texas }\end{array}$ & $\begin{array}{l}\text { Cross- } \\
\text { sectional } \\
\text { In } 2009 \text { - } \\
2010\end{array}$ & $\begin{array}{l}\text { BMI }\left(\mathrm{kg} / \mathrm{m}^{2}\right) \\
\text { BF\%: } \\
\text { measured by } \\
\text { bioelectric } \\
\text { impedance }\end{array}$ & $\begin{array}{l}\text { CRP }(\mu \mathrm{g} / \mathrm{mL}) \\
\text { Plasma } \\
\text { ELISA } \\
\mathrm{CV}=\text { Not } \\
\text { reported } \\
\text { IL-6 }(\mathrm{pg} / \mathrm{ml}) \\
\text { Plasma } \\
\text { ELISA } \\
\text { CV = Not } \\
\text { reported } \\
\text { TNF- } \alpha \text { (pg/ml) } \\
\text { Plasma } \\
\text { ELISA } \\
\text { CV = Not } \\
\text { reported } \\
\text { Overnight fast }\end{array}$ & $\begin{array}{l}\text { CRP was } \\
\text { significantly } \\
\text { correlated with } \\
\text { BMI }(p<0.01) \\
\text { and BF\% ( } p< \\
0.001) \text { in } \\
\text { university } \\
\text { students. } \\
\text { M vs. F } \\
\text { CRP was not } \\
\text { significantly } \\
\text { correlated with } \\
\text { BMI and BF\% in } \\
\text { male, whereas } \\
\text { CRP was } \\
\text { significantly } \\
\text { correlated with } \\
\text { BMI ( } p<0.01) \\
\text { and BF\% ( } p< \\
0.001) \text { in } \\
\text { females. } \\
\text { IL-6 and TNF- } \alpha \\
\text { were not } \\
\text { significant } \\
\text { correlated with } \\
\text { BMI and BF\% } \\
\text { in university } \\
\text { students as well } \\
\text { as both genders. }\end{array}$ & 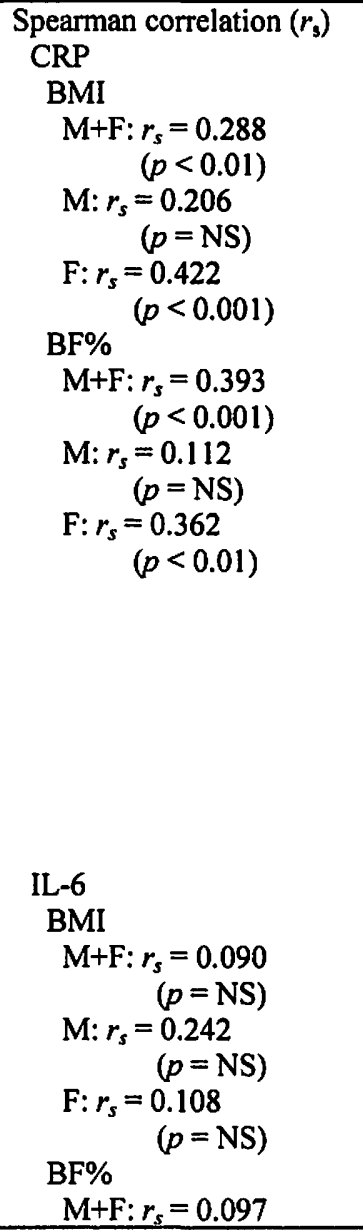 & No \\
\hline
\end{tabular}




\begin{tabular}{|c|c|c|c|c|c|c|c|c|}
\hline $\begin{array}{l}\text { Author, } \\
\text { year, } \\
\text { country }\end{array}$ & Purpose & $\begin{array}{l}\text { Participants } \\
\text { (N/sex/age/adiposity/inflammatory } \\
\text { markers: mean } \pm \text { SD), } \\
\text { setting/location }\end{array}$ & $\begin{array}{l}\text { Design, } \\
\text { study } \\
\text { period }\end{array}$ & $\begin{array}{l}\text { Anthropometric } \\
\text { adiposity } \\
\text { measures } \\
\text { (BMI, WC, } \\
\text { WHR, WHtR, } \\
\text { BF\%) }\end{array}$ & $\begin{array}{l}\text { Inflammatory } \\
\text { markers } \\
\text { (CRP, IL-6, TNF- } \alpha \text { ) } \\
\text { measurement site, } \\
\text { assay, CV }\end{array}$ & Results & Analysis and significance & $\begin{array}{l}\text { Adjustments } \\
\text { for } \\
\text { covariates }\end{array}$ \\
\hline & & & & & & & 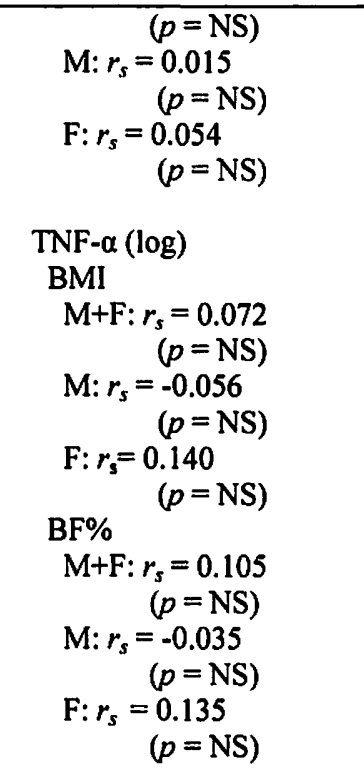 & \\
\hline
\end{tabular}




\begin{tabular}{|c|c|c|c|c|c|c|c|c|c|}
\hline $\begin{array}{l}\text { Author, } \\
\text { year, } \\
\text { country }\end{array}$ & Purpose & $\begin{array}{l}\text { Participants } \\
\text { (N/sex/age/adipo } \\
\text { markers: mean } \pm \\
\text { setting/location }\end{array}$ & lammatory & $\begin{array}{l}\text { Design, } \\
\text { study } \\
\text { period }\end{array}$ & $\begin{array}{l}\text { Anthropometric } \\
\text { adiposity } \\
\text { measures } \\
\text { (BMI, WC, } \\
\text { WHR, WHtR, } \\
\text { BF\%) }\end{array}$ & $\begin{array}{l}\text { Inflammatory } \\
\text { markers } \\
\text { (CRP, IL-6, TNF-a) } \\
\text { measurement site, } \\
\text { assay, CV }\end{array}$ & Results & Analysis and significance & $\begin{array}{l}\text { Adjustments } \\
\text { for } \\
\text { covariates }\end{array}$ \\
\hline $\begin{array}{l}\text { Williams } \\
\text { et al, } \\
2002 \text {, } \\
\text { New } \\
\text { Zealand }\end{array}$ & $\begin{array}{l}\text { To evaluate the } \\
\text { relationship } \\
\text { between ferritin, } \\
\text { metabolic } \\
\text { cardiovascular } \\
\text { risk factors, } \\
\text { CRP, and } \\
\text { anthropometric } \\
\text { measurements in } \\
\text { young men and } \\
\text { women. }\end{array}$ & $\begin{array}{l}\mathrm{N}=815 \\
(\mathrm{M} / \mathrm{F}=436 / 379) \\
\text { Age } 26 \mathrm{y} \\
\\
\text { BMI (M) } \\
24.8 \pm 4.7 \\
\text { WC (M) } \\
84.2 \pm 8.3 \mathrm{~cm} \\
\text { CRP (M) } \\
2.4 \pm 4.4 \mathrm{mg} / \mathrm{L} \\
\text { BMI (F) } \\
25.2 \pm 3.9 \\
\text { WC (F) } \\
75.4 \pm 9.3 \mathrm{~cm} \\
\text { CRP (F) } \\
5.3 \pm 6.8 \mathrm{mg} / \mathrm{L}\end{array}$ & $\begin{array}{l}\text { The } \\
\text { Dunedin } \\
\text { Multidiscip } \\
\text { linary } \\
\text { Health and } \\
\text { Developme } \\
\text { nt Study, a } \\
\text { longitudina } \\
\text { I follow up } \\
\text { study, } \\
\text { Dunedin, } \\
\text { New } \\
\text { Zealand }\end{array}$ & $\begin{array}{l}\text { Cross- } \\
\text { sectional } \\
\text { At age } \\
26 y\end{array}$ & $\begin{array}{l}\text { BMI }\left(\mathrm{kg} /{ }^{2}\right) \\
\text { WC }(\mathrm{cm}): \\
\text { Measured the } \\
\text { half way } \\
\text { between the } \\
\text { coastal border } \\
\text { and the iliac } \\
\text { crest }\end{array}$ & $\begin{array}{l}\text { CRP (mg/L) } \\
\text { Serum } \\
\text { Immune- } \\
\text { turbidimetric } \\
\text { assay using non- } \\
\text { hs assay } \\
\text { Intra-assay CV } \\
=\text { Not reported } \\
\text { Inter-assay CV } \\
=5.6-12.9 \% \\
\text { Non-fasting }\end{array}$ & $\begin{array}{l}\text { CRP was } \\
\text { significantly } \\
\text { correlated with } \\
\text { BMI and WC in } \\
\text { young men and } \\
\text { women } \\
(p<0.05) .\end{array}$ & $\begin{array}{c}\text { Univariate correlation } \\
\text { BMI (M): } r=0.11 \\
(p<0.05) \\
\text { WC (M): } r=0.10 \\
(p<0.05) \\
\text { BMI (F): } r=0.29 \\
(p \leq 0.0001) \\
\text { WC (F): } r=0.27 \\
(p \leq 0.0001)\end{array}$ & No \\
\hline
\end{tabular}

Abbreviations: N, number; M, male; F, female; BMI, body mass index; WC, waist circumference; WHR, waist to hip ratio; WHtR, waist to height ratio; BF, body fat; CRP, creactive protein; hs, high sensitivity: IL-6, interleukin 6; TNF- $\alpha$, tumor necrosis factor alpha; log, log transformed (logarithmically transformed); ELISA, enzyme-linked immunosorbent assay; RIA, radioimmunoassay; $y$, year; $\mathrm{CV}=$ coefficient of variation; OR, Odds Ratio; CI, confidence interval; NA, not applicable; NS, not significance; $\mathrm{CV}$, cardiovascular; CVD, cardiovascular disease; HOMA-IR, homeostasis model assessment of insulin resistance; SF, skinfold; wt, weight; min, minimum; max, maximum; MS, metabolic syndrome; UK, United Kingdom; ref, reference 
Table 3

Quality assessment of included studies in Adolescents

\begin{tabular}{|c|c|c|c|c|c|c|c|c|c|c|c|c|}
\hline \multirow{2}{*}{$\begin{array}{l}\text { Study, year, } \\
\text { journal }\end{array}$} & \multirow{2}{*}{$\begin{array}{l}\text { Design: } \\
\text { Were } \\
\text { study } \\
\text { design } \\
\text { clearly } \\
\text { described? }\end{array}$} & \multicolumn{3}{|l|}{ Sample } & \multirow{2}{*}{$\begin{array}{l}\text { Setting: } \\
\text { Was } \\
\text { setting } \\
\text { clearly } \\
\text { described? }\end{array}$} & \multicolumn{2}{|l|}{ Measurements } & \multicolumn{3}{|l|}{ Analyses } & \multirow{2}{*}{\begin{tabular}{|l}
$\begin{array}{l}\text { Peer } \\
\text { review } \\
\text { journal: }\end{array}$ \\
Was this \\
publication \\
peer- \\
reviewed?
\end{tabular}} & \multirow{2}{*}{$\begin{array}{l}\text { Quality } \\
\text { Indicat } \\
\text { ors met }\end{array}$} \\
\hline & & $\begin{array}{l}\text { Were } \\
\text { eligibilit } \\
\text { y criteria } \\
\text { specified } \\
?\end{array}$ & $\begin{array}{l}\text { Were any } \\
\text { sources and } \\
\text { methods of } \\
\text { selection of } \\
\text { participants } \\
\text { clearly } \\
\text { described? }\end{array}$ & $\begin{array}{l}\text { Was sample } \\
\text { size clearly } \\
\text { justified and } \\
\text { determined? }\end{array}$ & & $\begin{array}{l}\text { Were } \\
\text { anthropometric } \\
\text { adiposity } \\
\text { variables } \\
\text { reliably } \\
\text { measured and } \\
\text { described? }\end{array}$ & $\begin{array}{l}\text { Were the } \\
\text { inflammato } \\
\text { ry markers } \\
\text { measured } \\
\text { using valid } \\
\text { instruments } \\
?\end{array}$ & $\begin{array}{l}\text { Were the } \\
\text { statistical } \\
\text { methods to } \\
\text { infer the } \\
\text { independent } \\
\text { (exposure) } \\
\text { variable and } \\
\text { dependent } \\
\text { (outcome) } \\
\text { variables } \\
\text { associated/corr } \\
\text { elated/covary? }\end{array}$ & $\begin{array}{l}\text { Were the } \\
\text { statistical } \\
\text { methods of } \\
\text { data analysis } \\
\text { appropriate } \\
\text { for the levels } \\
\text { of } \\
\text { measurement } \\
\text { of the } \\
\text { variable? }\end{array}$ & $\begin{array}{l}\text { Was the } \\
\text { adequate } \\
\text { adjustment } \\
\text { for } \\
\text { confounding } \\
\text { in the } \\
\text { analyses? }\end{array}$ & & \\
\hline $\begin{array}{l}\text { Denney- } \\
\text { Wilson et al, } \\
2008, \\
\text { Archives of } \\
\text { Pediatrics and } \\
\text { Adolescent } \\
\text { Medicine } \\
\end{array}$ & Yes & No & Yes & No & Yes & Yes & Yes & Yes & Yes & No & Yes & $8 / 11$ \\
\hline $\begin{array}{l}\text { El-Wakkad et } \\
\text { al., Cytokine }\end{array}$ & $\begin{array}{l}\text { Not } \\
\text { reported }\end{array}$ & Yes & Yes & No & Yes & Yes & Yes & Yes & Yes & No & Yes & $8 / 11$ \\
\hline $\begin{array}{l}\text { Herder et al, } \\
2007, \\
\text { Journal of } \\
\text { Clinical } \\
\text { Endocrinology } \\
\text { and } \\
\text { Metabolism }\end{array}$ & Yes & No & Yes & No & Yes & Yes & Yes & Yes & Yes & Yes & Yes & $9 / 11$ \\
\hline
\end{tabular}




\begin{tabular}{|c|c|c|c|c|c|c|c|c|c|c|c|c|}
\hline \multirow{2}{*}{$\begin{array}{l}\text { Study, year, } \\
\text { journal }\end{array}$} & \multirow{2}{*}{$\begin{array}{l}\text { Design: } \\
\text { Were } \\
\text { study } \\
\text { design } \\
\text { clearly } \\
\text { described? }\end{array}$} & \multicolumn{3}{|l|}{ Sample } & \multirow{2}{*}{$\begin{array}{l}\text { Setting: } \\
\text { Was } \\
\text { setting } \\
\text { clearly } \\
\text { described? }\end{array}$} & \multicolumn{2}{|c|}{ Measurements } & \multicolumn{3}{|l|}{ Analyses } & \multirow{2}{*}{$\begin{array}{l}\begin{array}{l}\text { Peer } \\
\text { review } \\
\text { journal: }\end{array} \\
\text { Was this } \\
\text { publication } \\
\text { peer- } \\
\text { reviewed? }\end{array}$} & \multirow{2}{*}{$\begin{array}{l}\text { Quality } \\
\text { Indicat } \\
\text { ors met }\end{array}$} \\
\hline & & $\begin{array}{l}\text { Were } \\
\text { eligibilit } \\
\text { y criteria } \\
\text { specified } \\
?\end{array}$ & $\begin{array}{l}\text { Were any } \\
\text { sources and } \\
\text { methods of } \\
\text { selection of } \\
\text { participants } \\
\text { clearly } \\
\text { described? }\end{array}$ & $\begin{array}{l}\text { Was sample } \\
\text { size clearly } \\
\text { justified and } \\
\text { determined? }\end{array}$ & & $\begin{array}{l}\text { Were } \\
\text { anthropometric } \\
\text { adiposity } \\
\text { variables } \\
\text { reliably } \\
\text { measured and } \\
\text { described? }\end{array}$ & $\begin{array}{l}\text { Were the } \\
\text { inflammato } \\
\text { ry markers } \\
\text { measured } \\
\text { using valid } \\
\text { instruments } \\
?\end{array}$ & $\begin{array}{l}\text { Were the } \\
\text { statistical } \\
\text { methods to } \\
\text { infer the } \\
\text { independent } \\
\text { (exposure) } \\
\text { variable and } \\
\text { dependent } \\
\text { (outcome) } \\
\text { variables } \\
\text { associated/corr } \\
\text { elated/covary? }\end{array}$ & $\begin{array}{l}\text { Were the } \\
\text { statistical } \\
\text { methods of } \\
\text { data analysis } \\
\text { appropriate } \\
\text { for the levels } \\
\text { of } \\
\text { measurement } \\
\text { of the } \\
\text { variable? }\end{array}$ & $\begin{array}{l}\text { Was the } \\
\text { adequate } \\
\text { adjustment } \\
\text { for } \\
\text { confounding } \\
\text { in the } \\
\text { analyses? }\end{array}$ & & \\
\hline $\begin{array}{l}\text { Huang et al, } \\
2011, \\
\text { International } \\
\text { Journal of } \\
\text { Pediatric } \\
\text { Obesity }\end{array}$ & Yes & No & Yes & No & Yes & Yes & Yes & Yes & Yes & Yes & Yes & $9 / 11$ \\
\hline $\begin{array}{l}\text { Jung et al, } \\
2009, \\
\text { Pediatric } \\
\text { Diabetes }\end{array}$ & $\begin{array}{l}\text { Not } \\
\text { reported }\end{array}$ & Yes & Yes & No & Yes & Not reported & No & Yes & Yes & No & Yes & $6 / 11$ \\
\hline $\begin{array}{l}\text { Khan et al, } \\
2010, \\
\text { Obesity } \\
\text { Research and } \\
\text { Clinical } \\
\text { Practice }\end{array}$ & Yes & Yes & Yes & No & Yes & Yes & Yes & Yes & Yes & Yes & Yes & $10 / 11$ \\
\hline $\begin{array}{l}\text { Martinex- } \\
\text { Gomez et al, } \\
2010, \\
\text { International } \\
\text { Journal of } \\
\text { Obesity }\end{array}$ & Yes & No & Yes & No & Yes & Yes & Yes & Yes & Yes & Yes & Yes & $9 / 11$ \\
\hline
\end{tabular}




\begin{tabular}{|c|c|c|c|c|c|c|c|c|c|c|c|c|}
\hline \multirow{2}{*}{$\begin{array}{l}\text { Study, year, } \\
\text { journal }\end{array}$} & \multirow{2}{*}{$\begin{array}{l}\text { Design: } \\
\text { Were } \\
\text { study } \\
\text { design } \\
\text { clearly } \\
\text { described? }\end{array}$} & \multicolumn{3}{|l|}{ Sample } & \multirow{2}{*}{$\begin{array}{l}\text { Setting: } \\
\text { Was } \\
\text { setting } \\
\text { clearly } \\
\text { described? }\end{array}$} & \multicolumn{2}{|l|}{ Measurements } & \multicolumn{3}{|l|}{ Analyses } & \multirow{2}{*}{$\begin{array}{l}\begin{array}{l}\text { Peer } \\
\text { review } \\
\text { journal: }\end{array} \\
\text { Was this } \\
\text { publication } \\
\text { peer- } \\
\text { reviewed? }\end{array}$} & \multirow{2}{*}{$\begin{array}{l}\text { Quality } \\
\text { Indicat } \\
\text { ors met }\end{array}$} \\
\hline & & $\begin{array}{l}\text { Were } \\
\text { eligibilit } \\
\text { y criteria } \\
\text { specified } \\
?\end{array}$ & $\begin{array}{l}\text { Were any } \\
\text { sources and } \\
\text { methods of } \\
\text { selection of } \\
\text { participants } \\
\text { clearly } \\
\text { described? }\end{array}$ & $\begin{array}{l}\text { Was sample } \\
\text { size clearly } \\
\text { justified and } \\
\text { determined? }\end{array}$ & & $\begin{array}{l}\text { Were } \\
\text { anthropometric } \\
\text { adiposity } \\
\text { variables } \\
\text { reliably } \\
\text { measured and } \\
\text { described? }\end{array}$ & $\begin{array}{l}\text { Were the } \\
\text { inflammato } \\
\text { ry markers } \\
\text { measured } \\
\text { using valid } \\
\text { instruments } \\
?\end{array}$ & $\begin{array}{l}\text { Were the } \\
\text { statistical } \\
\text { methods to } \\
\text { infer the } \\
\text { independent } \\
\text { (exposure) } \\
\text { variable and } \\
\text { dependent } \\
\text { (outcome) } \\
\text { variables } \\
\text { associated/corr } \\
\text { elated/covary? }\end{array}$ & $\begin{array}{l}\text { Were the } \\
\text { statistical } \\
\text { methods of } \\
\text { data analysis } \\
\text { appropriate } \\
\text { for the levels } \\
\text { of } \\
\text { measurement } \\
\text { of the } \\
\text { variable? }\end{array}$ & $\begin{array}{l}\text { Was the } \\
\text { adequate } \\
\text { adjustment } \\
\text { for } \\
\text { confounding } \\
\text { in the } \\
\text { analyses? }\end{array}$ & & \\
\hline $\begin{array}{l}\text { Moon et al, } \\
2004, \\
\text { Metabolism: } \\
\text { Clinical \& } \\
\text { Experimental }\end{array}$ & Yes & Yes & $\begin{array}{l}\text { Not } \\
\text { reported }\end{array}$ & No & $\begin{array}{l}\text { Not } \\
\text { reported }\end{array}$ & Yes & Yes & Yes & Yes & No & Yes & $7 / 11$ \\
\hline $\begin{array}{l}\text { Petty et al, } \\
2010, \\
\text { International } \\
\text { Journal of } \\
\text { Pediatric } \\
\text { Obesity }\end{array}$ & Yes & Yes & Yes & No & Yes & Yes & Yes & Yes & Yes & Yes & Yes & $10 / 11$ \\
\hline $\begin{array}{l}\text { Serrano et al, } \\
2010, \\
\text { Arquivos } \\
\text { Brasileiros De } \\
\text { Cardiologia }\end{array}$ & Yes & No & Yes & No & Yes & Yes & No & Yes & Yes & No & Yes & $7 / 11$ \\
\hline $\begin{array}{l}\text { Vikram et al, } \\
2006, \\
\text { Indian Journal } \\
\text { of Medical } \\
\text { Research }\end{array}$ & Yes & Yes & Yes & No & Yes & Yes & Yes & Yes & Yes & No & Yes & $9 / 11$ \\
\hline
\end{tabular}




\begin{tabular}{|c|c|c|c|c|c|c|c|c|c|c|c|c|}
\hline \multirow{2}{*}{$\begin{array}{l}\text { Study, year, } \\
\text { journal }\end{array}$} & \multirow{2}{*}{$\begin{array}{l}\text { Design: } \\
\text { Were } \\
\text { study } \\
\text { design } \\
\text { clearly } \\
\text { described? }\end{array}$} & \multicolumn{3}{|l|}{ Sample } & \multirow{2}{*}{$\begin{array}{l}\text { Setting: } \\
\text { Was } \\
\text { setting } \\
\text { clearly } \\
\text { described? }\end{array}$} & \multicolumn{2}{|c|}{ Measurements } & \multicolumn{3}{|l|}{ Analyses } & \multirow{2}{*}{ 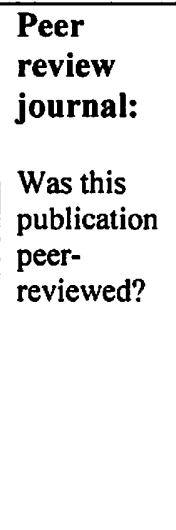 } & \multirow{2}{*}{$\begin{array}{l}\text { Quality } \\
\text { Indicat } \\
\text { ors met }\end{array}$} \\
\hline & & $\begin{array}{l}\text { Were } \\
\text { eligibilit } \\
\text { y criteria } \\
\text { specified } \\
?\end{array}$ & $\begin{array}{l}\text { Were any } \\
\text { sources and } \\
\text { methods of } \\
\text { selection of } \\
\text { participants } \\
\text { clearly } \\
\text { described? }\end{array}$ & $\begin{array}{l}\text { Was sample } \\
\text { size clearly } \\
\text { justified and } \\
\text { determined? }\end{array}$ & & $\begin{array}{l}\text { Were } \\
\text { anthropometric } \\
\text { adiposity } \\
\text { variables } \\
\text { reliably } \\
\text { measured and } \\
\text { described? }\end{array}$ & $\begin{array}{l}\text { Were the } \\
\text { inflammato } \\
\text { ry markers } \\
\text { measured } \\
\text { using valid } \\
\text { instruments } \\
?\end{array}$ & $\begin{array}{l}\text { Were the } \\
\text { statistical } \\
\text { methods to } \\
\text { infer the } \\
\text { independent } \\
\text { (exposure) } \\
\text { variable and } \\
\text { dependent } \\
\text { (outcome) } \\
\text { variables } \\
\text { associated/corr } \\
\text { elated/covary? }\end{array}$ & $\begin{array}{l}\text { Were the } \\
\text { statistical } \\
\text { methods of } \\
\text { data analysis } \\
\text { appropriate } \\
\text { for the levels } \\
\text { of } \\
\text { measurement } \\
\text { of the } \\
\text { variable? }\end{array}$ & $\begin{array}{l}\text { Was the } \\
\text { adequate } \\
\text { adjustment } \\
\text { for } \\
\text { confounding } \\
\text { in the } \\
\text { analyses? }\end{array}$ & & \\
\hline $\begin{array}{l}\text { Wang, } \\
\text { Christoffel et } \\
\text { al, 2011, } \\
\text { Journal of } \\
\text { Clinical } \\
\text { Endocrinology } \\
\text { and } \\
\text { Metabolism } \\
\end{array}$ & Yes & No & Yes & No & Yes & Yes & Yes & Yes & Yes & Yes & Yes & $9 / 11$ \\
\hline $\begin{array}{l}\text { Wärnberg et } \\
\text { al, 2006, } \\
\text { American } \\
\text { Journal of } \\
\text { Clinical } \\
\text { Nutrition }\end{array}$ & Yes & Yes & Yes & No & Yes & Yes & Yes & Yes & Yes & Yes & Yes & $10 / 11$ \\
\hline
\end{tabular}


Table 4

Quality assessment of included studies in Young Adults

\begin{tabular}{|c|c|c|c|c|c|c|c|c|c|c|c|c|}
\hline \multirow{2}{*}{$\begin{array}{l}\text { Study, year, } \\
\text { journal }\end{array}$} & \multirow{2}{*}{$\begin{array}{l}\text { Design: } \\
\text { Were study } \\
\text { design } \\
\text { clearly } \\
\text { described? }\end{array}$} & \multicolumn{3}{|l|}{ Sample } & \multirow{2}{*}{$\begin{array}{l}\text { Setting: } \\
\text { Was } \\
\text { setting } \\
\text { clearly } \\
\text { described? }\end{array}$} & \multicolumn{2}{|c|}{ Measurements } & \multicolumn{3}{|l|}{ Analyses } & \multirow{2}{*}{$\begin{array}{l}\text { Peer } \\
\text { review } \\
\text { journal: } \\
\text { Was this } \\
\text { publication } \\
\text { peer- } \\
\text { reviewed? }\end{array}$} & \multirow{2}{*}{$\begin{array}{l}\text { Quality } \\
\text { Indicat } \\
\text { ors met }\end{array}$} \\
\hline & & $\begin{array}{l}\text { Were } \\
\text { eligibility } \\
\text { criteria } \\
\text { specified? }\end{array}$ & $\begin{array}{l}\text { Were any } \\
\text { sources and } \\
\text { methods of } \\
\text { selection of } \\
\text { participants } \\
\text { clearly } \\
\text { described? }\end{array}$ & $\begin{array}{l}\text { Was } \\
\text { sample size } \\
\text { clearly } \\
\text { justified } \\
\text { and } \\
\text { determined } \\
?\end{array}$ & & $\begin{array}{l}\text { Were } \\
\text { anthropometric } \\
\text { adiposity } \\
\text { variables } \\
\text { reliably } \\
\text { measured and } \\
\text { described? }\end{array}$ & $\begin{array}{l}\text { Were the } \\
\text { inflammatory } \\
\text { markers } \\
\text { measured } \\
\text { using valid } \\
\text { instruments? }\end{array}$ & $\begin{array}{l}\text { Were the } \\
\text { statistical } \\
\text { methods to } \\
\text { infer the } \\
\text { independent } \\
\text { (exposure) } \\
\text { variable and } \\
\text { dependent } \\
\text { (outcome) } \\
\text { variables } \\
\text { associated/cor } \\
\text { related/covary } \\
?\end{array}$ & $\begin{array}{l}\text { Were the } \\
\text { statistical } \\
\text { methods of } \\
\text { data analysis } \\
\text { appropriate } \\
\text { for the levels } \\
\text { of } \\
\text { measurement } \\
\text { of the } \\
\text { variable? }\end{array}$ & $\begin{array}{l}\text { Was the } \\
\text { adequate } \\
\text { adjustme } \\
\text { nt for } \\
\text { confound } \\
\text { ing in the } \\
\text { analyses } \\
\text { ? }\end{array}$ & & \\
\hline $\begin{array}{l}\text { Bo et al., } \\
2004, \\
\text { Metabolism: } \\
\text { Clinical and } \\
\text { Experimental }\end{array}$ & Yes & Yes & Yes & No & Yes & Yes & Yes & Yes & Yes & No & Yes & $9 / 11$ \\
\hline $\begin{array}{l}\text { Bo et al., } \\
2004, \\
\text { Nutrition, } \\
\text { Metabolism } \\
\text { and } \\
\text { Cardiovascul } \\
\text { ar Diseases }\end{array}$ & Yes & Yes & Yes & No & Yes & Not reported & Yes & Yes & Yes & No & Yes & $8 / 11$ \\
\hline $\begin{array}{l}\text { Brydon et al., } \\
2008, \\
\text { International } \\
\text { Journal of } \\
\text { Obesity }\end{array}$ & Yes & Yes & Yes & No & Yes & Yes & Yes & Yes & Yes & Yes & Yes & $10 / 11$ \\
\hline
\end{tabular}




\begin{tabular}{|c|c|c|c|c|c|c|c|c|c|c|c|c|}
\hline \multirow{2}{*}{$\begin{array}{l}\text { Study, year, } \\
\text { journal }\end{array}$} & \multirow{2}{*}{$\begin{array}{l}\text { Design: } \\
\text { Were study } \\
\text { design } \\
\text { clearly } \\
\text { described? }\end{array}$} & \multicolumn{3}{|l|}{ Sample } & \multirow{2}{*}{$\begin{array}{l}\text { Setting: } \\
\text { Was } \\
\text { setting } \\
\text { clearly } \\
\text { described? }\end{array}$} & \multicolumn{2}{|c|}{ Measurements } & \multicolumn{3}{|l|}{ Analyses } & \multirow{2}{*}{$\begin{array}{l}\text { Peer } \\
\text { review } \\
\text { journal: } \\
\text { Was this } \\
\text { publication } \\
\text { peer- } \\
\text { reviewed? }\end{array}$} & \multirow{2}{*}{$\begin{array}{l}\text { Quality } \\
\text { Indicat } \\
\text { ors met }\end{array}$} \\
\hline & & $\begin{array}{l}\text { Were } \\
\text { eligibility } \\
\text { criteria } \\
\text { specified? }\end{array}$ & $\begin{array}{l}\text { Were any } \\
\text { sources and } \\
\text { methods of } \\
\text { selection of } \\
\text { participants } \\
\text { clearly } \\
\text { described? }\end{array}$ & $\begin{array}{l}\text { Was } \\
\text { sample size } \\
\text { clearly } \\
\text { justified } \\
\text { and } \\
\text { determined } \\
?\end{array}$ & & $\begin{array}{l}\text { Were } \\
\text { anthropometric } \\
\text { adiposity } \\
\text { variables } \\
\text { reliably } \\
\text { measured and } \\
\text { described? }\end{array}$ & $\begin{array}{l}\text { Were the } \\
\text { inflammatory } \\
\text { markers } \\
\text { measured } \\
\text { using valid } \\
\text { instruments? }\end{array}$ & $\begin{array}{l}\text { Were the } \\
\text { statistical } \\
\text { methods to } \\
\text { infer the } \\
\text { independent } \\
\text { (exposure) } \\
\text { variable and } \\
\text { dependent } \\
\text { (outcome) } \\
\text { variables } \\
\text { associated/cor } \\
\text { related/covary } \\
?\end{array}$ & $\begin{array}{l}\text { Were the } \\
\text { statistical } \\
\text { methods of } \\
\text { data analysis } \\
\text { appropriate } \\
\text { for the levels } \\
\text { of } \\
\text { measurement } \\
\text { of the } \\
\text { variable? }\end{array}$ & $\begin{array}{l}\text { Was the } \\
\text { adequate } \\
\text { adjustme } \\
\text { nt for } \\
\text { confound } \\
\text { ing in the } \\
\text { analyses } \\
\text { ? }\end{array}$ & & \\
\hline $\begin{array}{l}\text { Hermsdorff et } \\
\text { al., 2012, } \\
\text { Inflammation } \\
\text { Research }\end{array}$ & Yes & Yes & Yes & No & Yes & $\begin{array}{l}\text { Reported in a } \\
\text { previous } \\
\text { reference }\end{array}$ & Yes & Yes & Yes & Yes & Yes & $10 / 11$ \\
\hline $\begin{array}{l}\text { Hermsdorff et } \\
\text { al., 2011, } \\
\text { Inflammation }\end{array}$ & Yes & Yes & Yes & No & Yes & $\begin{array}{l}\text { Reported in a } \\
\text { previous } \\
\text { references }\end{array}$ & Yes & Yes & Yes & Yes & Yes & $10 / 11$ \\
\hline $\begin{array}{l}\text { McDade et } \\
\text { al., 2009, } \\
\text { American } \\
\text { Journal of } \\
\text { Clinical } \\
\text { Nutrition }\end{array}$ & Yes & No & Yes & No & Yes & $\begin{array}{l}\text { Reported in a } \\
\text { previous } \\
\text { references }\end{array}$ & Yes & Yes & Yes & No & Yes & $8 / 11$ \\
\hline $\begin{array}{l}\text { McDade et } \\
\text { al., 2011, } \\
\text { American } \\
\text { Journal of } \\
\text { Physical } \\
\text { Anthropology }\end{array}$ & Yes & Yes & Yes & No & Yes & Yes & Yes & Yes & Yes & Yes & Yes & $10 / 11$ \\
\hline
\end{tabular}




\begin{tabular}{|c|c|c|c|c|c|c|c|c|c|c|c|c|}
\hline \multirow{2}{*}{$\begin{array}{l}\text { Study, year, } \\
\text { journal }\end{array}$} & \multirow{2}{*}{$\begin{array}{l}\text { Design: } \\
\text { Were study } \\
\text { design } \\
\text { clearly } \\
\text { described? }\end{array}$} & \multicolumn{3}{|l|}{ Sample } & \multirow{2}{*}{$\begin{array}{l}\text { Setting: } \\
\text { Was } \\
\text { setting } \\
\text { clearly } \\
\text { described? }\end{array}$} & \multicolumn{2}{|l|}{ Measurements } & \multicolumn{3}{|l|}{ Analyses } & \multirow{2}{*}{$\begin{array}{l}\text { Peer } \\
\text { review } \\
\text { journal: } \\
\text { Was this } \\
\text { publication } \\
\text { peer- } \\
\text { reviewed? }\end{array}$} & \multirow{2}{*}{$\begin{array}{l}\text { Quality } \\
\text { Indicat } \\
\text { ors met }\end{array}$} \\
\hline & & $\begin{array}{l}\text { Were } \\
\text { eligibility } \\
\text { criteria } \\
\text { specified? }\end{array}$ & $\begin{array}{l}\text { Were any } \\
\text { sources and } \\
\text { methods of } \\
\text { selection of } \\
\text { participants } \\
\text { clearly } \\
\text { described? }\end{array}$ & $\begin{array}{l}\text { Was } \\
\text { sample size } \\
\text { clearly } \\
\text { justified } \\
\text { and } \\
\text { determined } \\
?\end{array}$ & & $\begin{array}{l}\text { Were } \\
\text { anthropometric } \\
\text { adiposity } \\
\text { variables } \\
\text { reliably } \\
\text { measured and } \\
\text { described? }\end{array}$ & $\begin{array}{l}\text { Were the } \\
\text { inflammatory } \\
\text { markers } \\
\text { measured } \\
\text { using valid } \\
\text { instruments? }\end{array}$ & $\begin{array}{l}\text { Were the } \\
\text { statistical } \\
\text { methods to } \\
\text { infer the } \\
\text { independent } \\
\text { (exposure) } \\
\text { variable and } \\
\text { dependent } \\
\text { (outcome) } \\
\text { variables } \\
\text { associated/cor } \\
\text { related/covary } \\
?\end{array}$ & $\begin{array}{l}\text { Were the } \\
\text { statistical } \\
\text { methods of } \\
\text { data analysis } \\
\text { appropriate } \\
\text { for the levels } \\
\text { of } \\
\text { measurement } \\
\text { of the } \\
\text { variable? }\end{array}$ & $\begin{array}{l}\text { Was the } \\
\text { adequate } \\
\text { adjustme } \\
\text { nt for } \\
\text { confound } \\
\text { ing in the } \\
\text { analyses } \\
?\end{array}$ & & \\
\hline $\begin{array}{l}\text { Mills et al., } \\
2008, \\
\text { Obesity }\end{array}$ & $\begin{array}{l}\text { Not } \\
\text { reported }\end{array}$ & Yes & Yes & No & Yes & Not reported & Yes & Yes & Yes & No & Yes & $7 / 11$ \\
\hline $\begin{array}{l}\text { Morrison et } \\
\text { al., } 2011 \text {, } \\
\text { ISRN } \\
\text { Pediatrics }\end{array}$ & Yes & No & Yes & No & Yes & Not reported & Yes & Yes & Yes & No & Yes & $7 / 11$ \\
\hline $\begin{array}{l}\text { Nazmi et al., } \\
2008, \\
\text { Brazilian } \\
\text { Journal of } \\
\text { Medical and } \\
\text { Biological } \\
\text { Research }\end{array}$ & Yes & No & Yes & Yes & Yes & Yes & Yes & Yes & Yes & Yes & Yes & $10 / 11$ \\
\hline $\begin{array}{l}\text { Orri et al., } \\
2010, \\
\text { Journal of } \\
\text { Sports } \\
\text { Medicine and } \\
\text { Physical } \\
\text { Fitness }\end{array}$ & Yes & No & Yes & No & Yes & Not reported & Yes & Yes & Yes & No & Yes & $7 / 11$ \\
\hline
\end{tabular}




\begin{tabular}{|c|c|c|c|c|c|c|c|c|c|c|c|c|}
\hline \multirow{2}{*}{$\begin{array}{l}\text { Study, year, } \\
\text { journal }\end{array}$} & \multirow{2}{*}{$\begin{array}{l}\text { Design: } \\
\text { Were study } \\
\text { design } \\
\text { clearly } \\
\text { described? }\end{array}$} & \multicolumn{3}{|l|}{ Sample } & \multirow{2}{*}{$\begin{array}{l}\text { Setting: } \\
\text { Was } \\
\text { setting } \\
\text { clearly } \\
\text { described? }\end{array}$} & \multicolumn{2}{|l|}{ Measurements } & \multicolumn{3}{|l|}{ Analyses } & \multirow{2}{*}{$\begin{array}{l}\text { Peer } \\
\text { review } \\
\text { journal: } \\
\text { Was this } \\
\text { publication } \\
\text { peer- } \\
\text { reviewed? }\end{array}$} & \multirow{2}{*}{$\begin{array}{l}\text { Quality } \\
\text { Indicat } \\
\text { ors met }\end{array}$} \\
\hline & & $\begin{array}{l}\text { Were } \\
\text { eligibility } \\
\text { criteria } \\
\text { specified? }\end{array}$ & $\begin{array}{l}\text { Were any } \\
\text { sources and } \\
\text { methods of } \\
\text { selection of } \\
\text { participants } \\
\text { clearly } \\
\text { described? }\end{array}$ & $\begin{array}{l}\text { Was } \\
\text { sample size } \\
\text { clearly } \\
\text { justified } \\
\text { and } \\
\text { determined } \\
?\end{array}$ & & $\begin{array}{l}\text { Were } \\
\text { anthropometric } \\
\text { adiposity } \\
\text { variables } \\
\text { reliably } \\
\text { measured and } \\
\text { described? }\end{array}$ & $\begin{array}{l}\text { Were the } \\
\text { inflammatory } \\
\text { markers } \\
\text { measured } \\
\text { using valid } \\
\text { instruments? }\end{array}$ & $\begin{array}{l}\text { Were the } \\
\text { statistical } \\
\text { methods to } \\
\text { infer the } \\
\text { independent } \\
\text { (exposure) } \\
\text { variable and } \\
\text { dependent } \\
\text { (outcome) } \\
\text { variables } \\
\text { associated/cor } \\
\text { related/covary } \\
\text { ? }\end{array}$ & $\begin{array}{l}\text { Were the } \\
\text { statistical } \\
\text { methods of } \\
\text { data analysis } \\
\text { appropriate } \\
\text { for the levels } \\
\text { of } \\
\text { measurement } \\
\text { of the } \\
\text { variable? }\end{array}$ & $\begin{array}{l}\text { Was the } \\
\text { adequate } \\
\text { adjustme } \\
\text { nt for } \\
\text { confound } \\
\text { ing in the } \\
\text { analyses } \\
?\end{array}$ & & \\
\hline $\begin{array}{l}\text { Perez et al., } \\
2003 \text {, } \\
\text { European } \\
\text { Journal of } \\
\text { Cardiovascul } \\
\text { ar Prevention } \\
\text { and } \\
\text { Rehabilitatio } \\
n\end{array}$ & Yes & Yes & Yes & No & Yes & Yes & Yes & Yes & Yes & No & Yes & $9 / 11$ \\
\hline $\begin{array}{l}\text { Raitakari et } \\
\text { al., } 2005 \text {, } \\
\text { Journal of } \\
\text { Internal } \\
\text { Medicine }\end{array}$ & Yes & Yes & Yes & No & Yes & Not reported & Yes & Yes & Yes & No & Yes & $8 / 11$ \\
\hline $\begin{array}{l}\text { Wang, Reed } \\
\text { et al., 2011, } \\
\text { Nutrition } \\
\text { Research }\end{array}$ & Yes & Yes & Yes & No & Yes & Yes & Yes & Yes & Yes & No & Yes & $9 / 11$ \\
\hline
\end{tabular}




\begin{tabular}{|c|c|c|c|c|c|c|c|c|c|c|c|c|}
\hline \multirow{2}{*}{$\begin{array}{l}\text { Study, year, } \\
\text { journal }\end{array}$} & \multirow{2}{*}{$\begin{array}{l}\text { Design: } \\
\text { Were study } \\
\text { design } \\
\text { clearly } \\
\text { described? }\end{array}$} & \multicolumn{3}{|l|}{ Sample } & \multirow{2}{*}{$\begin{array}{l}\text { Setting: } \\
\text { Was } \\
\text { setting } \\
\text { clearly } \\
\text { described? }\end{array}$} & \multicolumn{2}{|c|}{ Measurements } & \multicolumn{3}{|l|}{ Analyses } & \multirow{2}{*}{$\begin{array}{l}\text { Peer } \\
\text { review } \\
\text { journal: } \\
\text { Was this } \\
\text { publication } \\
\text { peer- } \\
\text { reviewed? }\end{array}$} & \multirow{2}{*}{$\begin{array}{l}\text { Quality } \\
\text { Indicat } \\
\text { ors met }\end{array}$} \\
\hline & & $\begin{array}{l}\text { Were } \\
\text { eligibility } \\
\text { criteria } \\
\text { specified? }\end{array}$ & $\begin{array}{l}\text { Were any } \\
\text { sources and } \\
\text { methods of } \\
\text { selection of } \\
\text { participants } \\
\text { clearly } \\
\text { described? }\end{array}$ & $\begin{array}{l}\text { Was } \\
\text { sample size } \\
\text { clearly } \\
\text { justified } \\
\text { and } \\
\text { determined } \\
?\end{array}$ & & $\begin{array}{l}\text { Were } \\
\text { anthropometric } \\
\text { adiposity } \\
\text { variables } \\
\text { reliably } \\
\text { measured and } \\
\text { described? }\end{array}$ & $\begin{array}{l}\text { Were the } \\
\text { inflammatory } \\
\text { markers } \\
\text { measured } \\
\text { using valid } \\
\text { instruments? }\end{array}$ & $\begin{array}{l}\text { Were the } \\
\text { statistical } \\
\text { methods to } \\
\text { infer the } \\
\text { independent } \\
\text { (exposure) } \\
\text { variable and } \\
\text { dependent } \\
\text { (outcome) } \\
\text { variables } \\
\text { associated/cor } \\
\text { related/covary } \\
?\end{array}$ & $\begin{array}{l}\text { Were the } \\
\text { statistical } \\
\text { methods of } \\
\text { data analysis } \\
\text { appropriate } \\
\text { for the levels } \\
\text { of } \\
\text { measurement } \\
\text { of the } \\
\text { variable? }\end{array}$ & $\begin{array}{l}\text { Was the } \\
\text { adequate } \\
\text { adjustme } \\
\text { nt for } \\
\text { confound } \\
\text { ing in the } \\
\text { analyses } \\
\text { ? }\end{array}$ & & \\
\hline $\begin{array}{l}\text { Williams et } \\
\text { al., 2002, } \\
\text { Atheroscleros } \\
\text { is }\end{array}$ & Yes & Yes & Yes & No & Yes & Yes & $\begin{array}{l}\text { No } \\
\text { (measuring } \\
\text { non-high } \\
\text { sensitivity } \\
\text { CRP assay) }\end{array}$ & Yes & Yes & No & Yes & $8 / 11$ \\
\hline
\end{tabular}


Association of Cardiorespiratory Fitness and Adiposity with Inflammatory Biomarkers in Young Adults

\author{
Eunduck Park, MSN, RN
}

The University of Texas Health Science Center at Houston

School of Nursing 


\begin{abstract}
Background

Low grade systemic inflammation plays a key role in atherosclerosis, and C-reactive protein (hs-CRP), interleukin-6 (IL-6), and tumor necrosis factor- alpha (TNF- $\alpha$ ), markers of systemic inflammation, are associated with cardiovascular events and adiposity. Cardiorespiratory fitness has shown health benefits by reducing circulating levels of inflammatory markers. However, it remains uncertain whether the negative association between cardiorespiratory fitness and inflammatory biomarkers is due to cardiorespiratory fitness itself or results from lower levels of adiposity. Moreover, the evidence examining the interaction between cardiorespiratory fitness and adiposity in inflammation in young adults is lacking.
\end{abstract}

\title{
Purpose
}

The aims of this study were to (1) determine the strength of the associations of cardiorespiratory fitness and adiposity (body mass index [BMI], waist circumference [WC]) with circulating levels of plasma hs-CRP, IL-6, and TNF- $\alpha$; and (2) test the moderating effect of adiposity on the strength of the association between cardiorespiratory fitness and circulating levels of plasma hs-CRP, IL-6, and TNF- $\alpha$.

\section{Methods}

A cross-sectional study was conducted with 88 young adults aged 20-34 years without diagnosed diseases. A submaximal treadmill walking test was used to assess cardiorespiratory fitness. BMI and WC were measured to assess adiposity. The hs-CRP, IL- 6 and TNF- $\alpha$ were assayed and were $\log _{10}$-transformed. For aim one, a separate multiple regression analysis was conducted with each of hs-CRP, IL-6, and TNF- $\alpha$ as 
dependent variables and adjusted for confounders. Analysis of covariance (ANCOVA) was used and adjusted for confounders for aim two. Confounding variables tested were sex, ethnicity, oral contraceptive use, and education level.

\section{Results}

Aim1: Cardiorespiratory fitness was not significantly associated with $\log _{10}$ hs-CRP after adjustment for BMI or WC and confounders. Cardiorespiratory fitness was not significantly associated with $\log _{10} \mathrm{IL}-6$ after adjustment for BMI and confounders. However, cardiorespiratory fitness was significantly and negatively associated with $\log _{10} \mathrm{IL}-6$ after adjustment for WC and confounders (Model adjusted $\mathrm{R}^{2}=.273, p<.0001$; $\beta=-.341, \mathrm{t}=-1.995, p=.049)$. Aim 2: Cardiorespiratory fitness $\times$ BMI or WC interaction was not significantly associated with $\log _{10}$ hs-CRP after adjustment for confounders. Similarly, cardiorespiratory fitness $\times \mathrm{BMI}$ interaction was not significantly associated with $\log _{10} \mathrm{IL}-6$ after adjustment for confounders. However, cardiorespiratory fitness $\times$ WC interaction was significantly associated with $\log _{10} \mathrm{IL}-6$ after adjustment for confounders (Model adjusted $\mathrm{R}^{2}=.258, p<.0001$; partial eta ${ }^{2}=.056, \mathrm{~F}=4.730, p=.033$ ). There were no associations of cardiorespiratory fitness, adiposity, and $\log _{10}$ TNF- $\alpha$.

\section{Conclusions}

In young adults, higher cardiorespiratory fitness is significantly associated with lower levels of IL-6, particularly in young adults with central adiposity. Further studies are warranted to determine if experimentally induced increases in cardiorespiratory fitness reduce inflammatory markers in young adults. Longitudinal studies are needed to understand the underlying inflammatory mechanisms related to interaction between 
cardiorespiratory fitness and adiposity, and its influence on cardiovascular disease risk in young adults.

Keywords: cardiorespiratory fitness; body mass index; waist circumference; c-reactive protein; interlukin- 6 ; tumor necrosis factor- $\alpha$; young adults 
Association of Cardiorespiratory Fitness and Adiposity with Inflammatory Biomarkers in Young Adults

Atherosclerotic cardiovascular disease (CVD) is a significant public health burden in the United States (Go et al., 2013). Atherosclerosis, a systemic disease process in which amassment of plaque builds up in the arterial wall, is the major underlying cause of the clinical CVD and CVD events (Go et al., 2013; Libby et al, 2009). It has been demonstrated that low-grade systemic inflammation plays a pivotal role in the initiation and progression of atherosclerosis (Libby et al., 2009) by impairing endothelial function (Ferri et al., 2007). Among the many inflammatory biomarkers, high sensitivity Creactive protein (hs-CRP), interleukinkin-6 (IL-6), and tumor necrosis factor -alpha (TNF- $\alpha$ ) are well-recognized markers of inflammation in relation to atherogenesis (Calabro, Golia, \& Yeh, 2009; Haddy et al., 2003).

C-reactive protein (CRP) is a major acute phase inflammatory protein, which is mainly produced by the liver in response to numerous inflammatory cytokines, particularly IL-6 (Bajpai, Goyal, \& Sperling, 2010). The "high sensitivity (hs)-CRP” term is defined as "the measurement of CRP in serum or plasma sample using immunoassay methods with sufficient sensitivity to quantify CRP throughout its normal range" in asymptomatic individuals (Bajpai, Goyal, \& Sperling, 2010, p.191). Hs-CRP detects the same CRP molecule as CRP test, but it detects substantially lower levels of inflammation (Bajpai, Goyal, \& Sperling, 2010). Numerous prospective studies have indicated that plasma level of hs-CRP is a strong independent predictor for future cardiovascular events in individual with no prior history of CVD (Buckley, Fu, Freeman, Rogers, \& Helfand, 2009; Ridker, 2001; Ridker, 2003). 
IL-6 is a pro-inflammatory cytokine and produced by fibroblasts, endothelial cells, monocytes, and adipose tissue (Schuett, Luchtefeld, Grothusen, Grote, \& Schieffer, 2009). IL-6 plays an important role in controlling hepatic production of inflammatory proteins, including hs-CRP and fibrinogen (Antuna-Puente, Feve, Fellahi, \& Bastard, 2008). A previous prospective study has reported that elevated levels of IL-6 are associated with increased risk of future myocardial infarction in 14,916 apparently healthy men (Ridker, Rifai, Stampfer, \& Hennekens, 2000).TNF- $\alpha$, a pro-inflammatory cytokine, is secreted by macrophages, lymphocytes, and adipose tissue (Petersen \& Pedersen, 2005). TNF- $\alpha$ activates the production of IL-6 in adipose tissue and blood mononuclear cells (Petersen \& Pedersen, 2005). It has been reported that TNF- $\alpha$ is associated with degree of early atherosclerosis and correlates with metabolic and cellular perturbations in atherogenesis (Skoog et al., 2002).

Although clinical symptoms of atherosclerotic CVD, such as chest pain or discomfort, shortness of breath or fatigue, numbness, and blurred vision are not commonly detected until adulthood it is a progressive atherosclerotic process that occurs early in life and has clinical indications for acute coronary syndrome and acute stroke usually later in life (Franks et al., 2010; Loria et al., 2007). Hence, young adults could be an optimal target for preventive endeavors to minimize or delay atherosclerotic process, which could eventually decrease the incidence of clinical CVD throughout middle and older adulthood (Loria et al., 2007).

This study is focused on cardiorespiratory fitness and adiposity of young adults in relation to hs-CRP, IL- 6 and TNF- $\alpha$. Cardiorespiratory fitness refers to "the ability of the circulatory and respiratory systems to supply oxygen and nutrients during sustained 
physical activity" (Caspersen, Powell, \& Christenson, 1985). Cardiorespiratory fitness is related to "the ability to perform large muscle dynamic, moderate-to-high intensity exercise for prolonged periods of time" (American College of Sports Medicine [ACSM], p.71). It has been reported that higher levels of cardiorespiratory fitness are closely related to higher levels of habitual physical activity (Blair et al., 1995). Maximal oxygen uptake $\left(\mathrm{VO}_{2 \max }\right)$ is the gold standard or criterion measure of cardiorespiratory fitness (ACSM, 2010) and is commonly assessed with either a maximal or submaximal exercise test, using a treadmill or cycle ergometer (ACSM, 2010). Cardiorespiratory fitness in this present study was estimated using a submaximal treadmill walking protocol, which utilizes individual's heart rate (HR) response to submaximal treadmill work rates to estimate $\mathrm{VO}_{2 \max }$ (Ebbeling et al., 1991). Although direct measurement of cardiorespiratory fitness using a maximal exercise test (with or without collection of expired gases) is more precise than a submaximal exercise test, the maximal exercise test is not always feasible or practical in health and research settings due to the need for expensive laboratory equipment, trained personnel, possible physician oversight, participant burden, and associated safety considerations (Heyward, 2010). Cardiorespiratory fitness has shown health benefits in lowering circulating levels of inflammatory biomarkers in various populations (Church, Barlow, Earnest, Kampert, Priest, \& Blair, 2002; Kullo, Khaleghi, \& Hensrud, 2007, Kuo, Yen, Chen, Yu, \& Bean, 2007; Isasi, Deckelbaum, Tracy, Starc, Berglund, \& Shea, 2003; Williams et al., 2005). However, it remains uncertain whether the negative association between cardiorespiratory fitness and inflammatory biomarkers is due to the health benefits of 
cardiorespiratory fitness itself or results from its association with lower levels of adiposity (Harmer, 2007).

Adiposity is defined as "the quality or state of being fat" (Merriam-Webster Dictionary), and a synonym for obesity or fatness (Merriam-Webster Dictionary). Adiposity has been assessed by anthropometric measures in public health and clinical practice. Adiposity in this study was assessed by BMI and waist circumference (WC). BMI $\left(\mathrm{kg} / \mathrm{m}^{2}\right)$ has been recommended for the identification of measuring total body fat and the most widely accepted measures of overall adiposity (Stevens, McClain, \& Truesdale, 2008); however, BMI does not differentiate fat mass from bone and muscle mass and does not provide any information on the distribution of body fat, particularly central body fat (Stevens, McClain, \& Truesdale, 2008). Thus, this study included WC for assessing central adiposity (Stevens, McClain, \& Truesdale, 2008). Adiposity has been positively associated with CRP in various populations (Brook, Blaha, \& Blumenthal, 2010; Choi, Joseph, \& Pilote, 2013).

Only two studies have reported the association of cardiorespiratory fitness and inflammation measured by CRP in young adults over the past decade (Kuo et al., 2007; Williams, Milne, Hancox, \& Poulton, 2006). Both studies reported that cardiorespiratory fitness was negatively associated with CRP in young adults independent of BMI, age, race, and cardiovascular risk factors, such as blood pressure, smoking, etc. In the study by Williams et al., investigators measured CRP using a low sensitivity CRP assay, which may underestimate the strength of the association between cardiorespiratory fitness and CRP (Williams et al., 2005). In the population-based study by Kuo et al., they included study participants with CVD risk factors, such as hypertension, diabetes and current 
smokers or participants with anti-inflammatory or CVD medications (Kuo et al., 2007), which may influence levels of inflammatory biomarkers. Neither study examined adiposity as moderator of the association between inflammation and cardiorespiratory fitness, nor the extent to which adiposity influences the association between cardiorespiratory fitness and inflammation. In addition, neither study assessed central adiposity in detail. Furthermore, these two previous studies focused only on CRP as a biomarker of inflammation. It is essential to investigate other inflammatory markers, such as IL-6 and TNF- $\alpha$ in order to better understand inflammatory processes in relation to adiposity and cardiorespiratory fitness.

This study aimed to (1) determine the strength of the association of cardiorespiratory fitness and adiposity (BMI and WC) with circulating levels of plasma hs-CRP, IL-6, and TNF- $\alpha$; and (2) test the moderating effect of adiposity (BMI and WC) on the strength of the association between cardiorespiratory fitness levels and circulating levels of plasma hs-CRP, IL-6, and TNF- $\alpha$ in young adults aged 20 to 34 years. This study may fill an important gap in the literature by providing data on the role of adiposity as a moderator of the strength of the association between cardiorespiratory fitness and three inflammatory biomarkers.

\section{Methods}

\section{Design}

This present study utilized a cross-sectional analytic design. Data were collected on each young adult through cardiorespiratory fitness testing, anthropometric measurement and blood sampling of inflammatory biomarkers in one session, lasting 
approximately one and half hours, at the University of Texas Health Science Center at Houston (UTHSC-H) School of Nursing (SON).

\section{Participant, sampling plan and recruitment}

The target population for this study was young adults aged 20 to 34 years residing in Houston, a large metropolitan city with an ethnically diverse population in southeast Texas. A sample of the population was accessed using a non-probability quota sampling approach in order to include approximately equal numbers of males and females of normal weight $\left(\mathrm{BMI}<25 \mathrm{~kg} / \mathrm{m}^{2}\right)$, and overweight or obese (BMI $\geq 25 \mathrm{~kg} / \mathrm{m}^{2}$ ). The estimated sample size was 88 subjects to detect a medium effect size $\left(0.059 \leq R^{2}<0.138\right)$ according to Cohen (1998), a power of $80 \%$, and an alpha level of .05 for a two-tailed test using nQuery Advisor version 7.0 (nQuery, Saugus, MA).

The inclusion criteria were: (1) young adults aged 20-34 years; (2) no diagnosed diseases; (3) physically capacity for completing the cardiorespiratory fitness testing safely (ACSM, 2010); and (4) ability to speak and read English. Exclusion criteria were: (1) current smoker; (2) alcohol dependence or regular consumption of more than 7 servings per week; (3) acute infections, including a current or recent influenza illness, flu shot recipients within last 4 weeks, acute respiratory infection within last 3weeks; (4) dental infection and problems; (5) cardiometabolic dieseases, such as hypertension, hyperlipidemia and diabetes mellitus type I or II; (6) rheumatoid arthritis or immune disorders; (7) history of inflammatory bowel disease, such as Crohn's disease and ulcerative colitis; (8) a surgery within the past one month; (9) currently taking medications, such as use of hormone replacement therapy, antihypertensive medications, allergy shots or systemic corticosteroids, aspirin, statin, and selective serotonin uptake 
inhibitors (SSRIs), and anti-inflammatory medications; (10) history of orthopedic injury in the past and limitations due to the musculoskeletal demands of cardiorespiratory test ; and (11) other medical conditions and medications that would increase inflammatory markers or would prohibit cardiorespiratory fitness testing (O'Connor et al., 2009). For females, additional inclusion criteria were: (1) self-reported regular menstrual cycle length of 24-35 days; and (2) self-report of no menstruation at the time of data collection because menses may affect the levels of hs-CRP (Gaskins et al., 2012). Additional exclusion criteria were: (1) natural or surgical menopause; (2) current or recent pregnancy (past 6 months); (3) currently or recently (past 2 months) lactating females (Williams, Williams \& Poulton, 2006); (4) history of gynecologic problems, such as fibroids, endometriosis, or polycystic ovary syndrome (Escobar-Morreale, LuqueRamírez, \& González, 2011); (5) use of contraceptive hormone patch or vaginal ring methods of contraception currently or within the past three months; and (6) intrauterine device (IUD) with hormones or Depo-Provera currently or within the past 12 months (Gaskins et al., 2011; O'Connor et al., 2009). This study included females who currently or in the past have taken oral contraceptives, and included as a covariate in the analysis. Participants were recruited by posting fliers in the UTHSC-H, surrounding communities of the UTHSC-H, and multiple campuses in Houston. The recruitment began at the end of March 2013 and continued through December 2013. Individuals interested in the study contacted the principal investigator (PI) by phone or e-mail and were screened by interview. Participants that met the selection criteria were invited to a data collection session. 


\section{Procedures}

The data were collected by the PI at the Center for Nursing Research in the UTHSC-H, school of nursing (SON). The fitness room was maintained between 68 and 76 degrees Fahrenheit, with a humidity level between 20 to 60 percent using a room temperature thermometer (Q-Track IAQ monitor, TSI Incorporated, Shoreview, MN) throughout the data collection period (ACSM, 2010).

To prepare for data collection, participants were instructed (1) to fast from eating food for 12-hours prior to test but were allowed to drink water only; (2) not to engage in strenuous exercise, consume alcohol, or use anti-inflammatory drugs 24 hours prior to blood sampling; (3) to arrive at the UTHSC-H SON bioscience laboratory between 8am and $10 \mathrm{am}$; (4) to wear comfortable exercise-type clothing; (5) to avoid caffeine 12- hours prior to test; (6) to consume plenty of fluids; and (7) to obtain an adequate amount of sleep the night before the test (ACSM, 2010). The informed consent was obtained from each participant. All procedures were administered by the PI. Participants received $\$ 10.00$ and a free sandwich for completion of data collection protocol. All study procedures were approved by the Committee for the Protection of Human Subjects at the UTHSC-H.

\section{Instruments and Data Collection}

Assessment of cardiorespiratory fitness. Cardiorespiratory fitness was assessed by a single-stage submaximal treadmill walking test (SSTWT). The SSTWT was developed by Ebbeling et al. (1991) for estimating $\mathrm{VO}_{2} \mathrm{max}$ of low-risk, healthy adults 20 to 50 years old. The SSTWT was validated by correlating the indirectly estimated $\mathrm{VO}_{2}$ max based on individual's walking speed, heart rate (HR), age and sex and the 
directly measured respiratory gas exchange $\left(\mathrm{VO}_{2} \mathrm{max}\right)$ in the cross-validation group $(\mathrm{n}=$ 22) (Ebbeling et al., 1991). A correlation ( $r$ ) of .96 was reported, with multiple correlation $\left(\mathrm{R}^{2}\right)$ of $.86(\mathrm{SEE}=4.85 \mathrm{ml} / \mathrm{kg} \cdot \mathrm{mim})($ Ebbeling et al., 1991).

Single-stage submaximal treadmill walking test protocol. The SSTWT consisted of a 4-minute warm-up stage, 4-minute workload stage, and a 2-5minute cool-down stage. The treadmill was calibrated before cardiorespiratory fitness test to ensure the accuracy of the test. Prior to beginning the SSTWT, participants were familiarized with the treadmill (Precor 956i, Precor, Inc., Woodinville, WA), including a visual demonstration in order to maximize participant safety. In the first warm-up stage, participants walked on the treadmill for 4-minutes at $0 \%$ incline and a walking speed ( 2.0 to $4.5 \mathrm{mph}$ ) that brings the HR to between $50 \%$ and $70 \%$ beats per minute (bpm) age-predicted maximal HR by the PI. In workload stage, the treadmill incline was increased to $5 \%$ at the same speed for a 4-to 5-minute period. Following a workload stage, the participants completed a cool-down stage at a slower walking pace and $0 \%$ incline for a 2-5minute period. Resting BP and HR using the oscillometric technique (HEM-907SL, Omron Healthcare, Inc., Bannockburn, IL) was assessed prior to a warmup stage, twice and after a cool-down stage one time. If the participant's resting blood pressure was $\geq 130 / 90 \mathrm{mmHg}$ or resting $\mathrm{HR} \geq 100 \mathrm{bpm}$, the participant was not allowed to continue with the SSTWT protocol. Polar HR (Vintage NV model, Polar CIC, Inc., Port Washington, NY) was recorded during the SSTWT protocol and the Borg Ratings of Perceived Exertion scale (RPE) was documented at the end of the warm-up stage and the workload stage. RPE provides a subjective indication of how hard the participant feels he or she is working with numbers, rating from 6 (very, very light) to 20 (very, very hard) 
(Borg, 1970). Steady-state HR is defined as a HR within 5 bpm during the last 2 minute of the workload stage. The main outcome of the cardiorespiratory test estimated maximal oxygen uptake $\left(\mathrm{VO}_{2} \mathrm{max}\right)$. The SSTWT prediction equation was used to estimate $\mathrm{VO}_{2}$ max based on age, sex, walking speed (mph), and steady-state HR.

Estimated VO2 $\max (\mathrm{ml} / \mathrm{kg} \cdot \min )=15.1+21.8($ speed in $\mathrm{mph})-0.327$ (steady state HR in bpm) - 0.263 (speed $x$ age in years) +0.00504 (SS HR in bpm age in years $)+5.98(\mathrm{sex} ;$ female $=0$, male $=1)$

Assessment of adiposity. Adiposity was assessed using BMI and WC. BMI was calculated by dividing the participant's weight in kilograms by the height in meters squared $\left(\mathrm{kg} / \mathrm{m}^{2}\right)$. Height was measured without shoes to the nearest $0.1 \mathrm{~cm}$ using a wallmounted stadiometer (Accustat, Genentech Inc.). Weight was measured to the nearest $1 / 4^{\text {th }} \mathrm{lb}$ with a calibrated balance beam scale. Height and weight were measured with minimal clothing and without shoes and hats (National Health and Nutrition Examination Survey [NHANES], 2010). WC was a measure of the degree of central of body fat. WC was measured to the nearest $0.1 \mathrm{~cm}$ using a flexible, nonstrectchable tape. The tape measure was placed just above the uppermost lateral border of the right ilium crest and was extended around the waist in a horizontal plane (NHANES, 2010). Height, weight, and waist circumference were repeated, and the mean of two measures was calculated.

Measurement of hs-CRP, IL-6, and TNF-a. Blood collection was taken after a 12-hour overnight fast. A $10 \mathrm{ml}$ blood sample was collected from an antecubital vein into two vacutainers containing ethylene diamine tetra acetic acid (EDTA) by the PI. The blood samples were immediately centrifuged at 1,630 relative centrifugal force ( $\mathrm{rcf}$ ) at $4^{\circ} \mathrm{C}$ for 30 minutes (Centrifuge5810R, Eppendorf AG Hamburg, Germany). After 
centrifugation, plasma samples were divided into eight aliquots and stored at $-80^{\circ} \mathrm{C}$ until batch assayed. Plasma hs-CRP was determined by the CRP Ultra Wide Range Reagent kit (Sekisui Diagnostics, Inc., PE, Canada), a latex-enhanced turbidimetric in vitro immunoassay (AU480 automated platform, Beckman Coulter, Marietta, GA) at the Atherosclerosis Clinical Research Laboratory at the Baylor College Medicine. The plasma hs-CRP samples exceeding the upper limit of linearity were diluted and repeated. The new values were multiplied by the dilution factor to generate a final reportable value. The detectable levels of hs-CRP ranged from 0.05 to $160 \mathrm{mg} / \mathrm{L}$. Intra-assay coefficient of variations (CV) for hs-CRP was $<3.3 \%$. Plasma IL-6 and TNF- $\alpha$ were determined using Quantikine high-sensitivity enzyme-linked immunosorbent assay (ELISA) kits (R\&D System, MN, USA) at the Bioscience Laboratory in the UTHSC-H SON. The detectable levels of IL-6 ranged from 0.156 to $10 \mathrm{pg} / \mathrm{mL}$, and the detectable levels of TNF- $\alpha$ ranged from 0.5 to $32 \mathrm{pg} / \mathrm{mL}$. IL- 6 and TNF- $\alpha$ were run on the WorkOut ${ }^{\mathrm{TM}}$ software (version 2.5, Perkin Elmer Life and Analytical Sciences). The intra-assay CV and inter-assay CV for IL-6 were $9.4 \%$ and $2.3 \%$, and inter-assay CV for TNF- $\alpha$ were $11.0 \%$ and $1.0 \%$ respectively.

Age, sex, ethnicity, education, oral contraceptive use were considered as possible confounders related to inflammation based on the previous studies (Cauci et al., 2008; Dreon, Slavin, \& Phinney, 2003; Friedman \& Herd, 2010; Ferrucci et al., 2005; KelleyHedgepeth et al., 2008; O'Connor et al., 2009; Paalani, Lee, Haddad, \& Tonstad, 2011). Statistical Analysis

Statistical analyses were performed by using statistical software SPSS version 22.0 (SPSS Inc., Chicago, IL). Descriptive data were presented as mean \pm standard 
deviation (SD), frequency and percentage. Data were checked for normality of distribution before analyses and were transformed as necessary. The distributions of hsCRP, IL-6, and TNF- $\alpha$ were positively skewed and were $\log _{10}$-transformed. All statistical tests were two-tailed and $\mathrm{p}$-value $<.05$ was considered statistically significant. Multiple regression analysis was used to examine aim 1: the strength of the association of cardiorespiratory fitness and adiposity with inflammatory biomarkers. For aim 2 , analysis of covariance (ANCOVA) was used to examine the association of cardiorespiratory fitness (continuous variable) $\times$ adiposity (categorical variables) interaction term with inflammatory biomarkers (continuous variable) as the outcome variable. Categories for adiposity were as follows; BMI was divided into $<25 \mathrm{~kg} / \mathrm{m}^{2}$ (normal weight) and BMI $\geq$ $25 \mathrm{~kg} / \mathrm{m}^{2}$ (overweight or obese), and WC was divided at the $50^{\text {th }}$ percentile (median value $=86.4 \mathrm{~cm}$ ); $\mathrm{WC}<86.4 \mathrm{~cm}$ and $\mathrm{WC} \geq 86.4 \mathrm{~cm}$. Separate analyses were conducted with each of the inflammatory markers (hs-CRP, IL-6, and TNF- $\alpha$ ) as the dependent variable. Analyses for aim 1 and 2 were adjusted for possible confounders including age, sex, or oral contraceptives (females only), ethnicity and education. The dichotomous variables of sex and use of oral contraceptives were considered as an interaction term, which resulted in three categories (males, females without oral contraceptives, and female with oral contraceptives). Variables that were statistically significantly related to the dependent variable $(p<.05)$ were included as confounding variables.

\section{Results}

\section{Descriptive Characteristics of Participants}

One hundred and thirty young adults were assessed for eligibility; 88 participants completed the study as shown in Figure 1. The descriptive characteristics of the 
participants are presented in Table 1. All participants $(n=88)$ had complete data for cardiorespiratory fitness, BMI, WC, hs-CRP, and TNF- $\alpha$, and 87 participants had IL-6 data. The mean of age of participants was $25.97 \pm 3.84(\mathrm{SD})$ years (range, 20-34 years), and $48.9 \%$ was males. The anthropometric and health characteristics of the sample are presented for the sample and for males and females separately in Table 2. Males had higher mean levels of cardiorespiratory fitness, and WC than females whereas female had higher mean levels of hs-CRP than males. Males and females had similar mean levels in BMI, IL-6, and TNF- $\alpha$.

\section{Associations of Cardiorespiratory Fitness and Adiposity (BMI and WC) with Log $_{10} h s-C R P$ and $\log _{10} I L-6$}

Multiple linear regression analysis was used with $\log _{10}$ hs-CRP as the outcome variable and cardiorespiratory fitness as predictor variables in Table 3. In multiple linear regression analysis, age, ethnicity, and education were not significant confounding variables related to $\log _{10} \mathrm{hs}-\mathrm{CRP}(p<.20)$. This study identified sex and oral contraceptives as important confounders related to $\log _{10}$ hs-CRP $(p<.20)$.

Cardiorespiratory fitness was significantly and negatively associated with $\log _{10}$ hs-CRP after adjustment for sex $\times$ oral contraceptive interaction term (Model1: adjusted $\mathrm{R}^{2}=$ $.300, \mathrm{~F}(2,84)=13.430, p<.0001 ; \beta$-coefficient $=-.639, \mathrm{t}=-4.920, p<.0001)$. However, after BMI was added to this model, cardiorespiratory fitness was not significantly associated with $\log _{10}$ hs-CRP (Model 2 : adjusted $R^{2}=.429, F(4,83)=$ $17.324, p<.0001 ; \beta$-coefficient $=-.178, \mathrm{t}=-1.137, p=.259)$. Likewise, after WC was added as a predictor, cardiorespiratory fitness was not significantly associated with 
$\log _{10}$ hs-CRP either (Model 3: adjusted $\mathrm{R}^{2}=.418, \mathrm{~F}(4,83)=16.641, p<.0001 ; \beta-$ coefficient $=-.202, \mathrm{t}=-1.291, p=.200)$.

In terms of $\log _{10} \mathrm{IL}-6$, multiple linear regression analysis was used with $\log _{10} \mathrm{IL}-6$ as the outcome variable and cardiorespiratory fitness as predictor variable in Table 4 . In multiple linear regression analysis, age and ethnicity were not significant confounding variables related to $\log _{10} \mathrm{IL}-6(p<.20)$. Therefore, this study identified sex and education as confounding variables in the statistical analysis of $\log _{10} \mathrm{IL}-6(p<.20)$.

Cardiorespiratory fitness was significantly and negatively associated with $\log _{10} \mathrm{IL}-6$ after adjustment for sex and education (Model1: adjusted $\mathrm{R}^{2}=.216, \mathrm{~F}(3,82)=6.921, p<$ $.0001 ; \beta$-coefficient $=-.638, \mathrm{t}=-4.673, p<.0001)$. When BMI was added to this model, cardiorespiratory fitness was not significantly associated with $\log _{10} \mathrm{IL}-6$ (Model 2 : adjusted $\mathrm{R}^{2}=.283, \mathrm{~F}(5,81)=7.801, p<.0001 ; \beta$-coefficient $=-.316, \mathrm{t}=-1.854, p$ $=.067)$. However, cardiorespiratory fitness was significantly and negatively associated with $\log _{10} \mathrm{IL}-6$ after WC was added to this model (Model 3: adjusted $\mathrm{R}^{2}=.273, \mathrm{~F}(5,81)$ $=7.459, p<.0001 ; \beta$-coefficient $=-.341, \mathrm{t}=-1.995, p=.049)$.

Interaction between Cardiorespiratory Fitness and Adiposity on Log $\log _{10}$-CRP

The results of the analysis of covariance (ANCOVA) to examine the association of cardiorespiratory fitness (continuous variable) $\times$ BMI (categorical variables) interaction term with $\log _{10} \mathrm{hs}$-CRP (continuous variable) as the outcome variable were presented in Table 5 . There was a statistically significant cardiorespiratory fitness $\times$ BMI interaction term for $\log _{10}$ hs-CRP (Model 1: adjusted $\mathrm{R}^{2}=.229, \mathrm{~F}(3,84)=9.607, p<$ .0001 ; interaction term, partial eta $\left.{ }^{2}=.051, \mathrm{~F}(1,84)=4.553, p=.036\right)$. The interaction effect is illustrated in Figure 2. For example, young adults with BMI $\geq 25 \mathrm{~kg} / \mathrm{m}^{2}$ and a 
high cardiorespiratory fitness level $(55 \mathrm{~mL} / \mathrm{kg} \cdot \mathrm{min})$ had a lower level of hs-CRP $(0.60$ $\mathrm{mg} / \mathrm{L})$ compared with the hs-CRP level $(2.39 \mathrm{mg} / \mathrm{L})$ of young adults with $\mathrm{BMI} \geq 25$ $\mathrm{kg} / \mathrm{m}^{2}$ and a low cardiorespiratory fitness level $(35 \mathrm{~mL} / \mathrm{kg} \cdot \mathrm{min})$. This suggests that higher levels of cardiorespiratory fitness are associated with lower levels of hs-CRP in young adults with $\mathrm{BMI}$ in the overweight/ obese range. In contrast, among those with $\mathrm{BMI}<25$ $\mathrm{kg} / \mathrm{m}^{2}$, the levels of hs-CRP did not vary by the level of cardiorespiratory fitness. For instance, as illustrated in Figure 2 young adults with BMI $<25 \mathrm{~kg} / \mathrm{m}^{2}$ and a high cardiorespiratory fitness level $(55 \mathrm{~mL} / \mathrm{kg} \cdot \min )$ had a hs-CRP $(0.45 \mathrm{mg} / \mathrm{L})$, which is very similar to those with BMI $<25 \mathrm{~kg} / \mathrm{m}^{2}$ and a low cardiorespiratory fitness level $(35 \mathrm{~mL} / \mathrm{kg} \cdot \mathrm{min}) \mathrm{hs}-\mathrm{CRP}(0.49 \mathrm{mg} / \mathrm{L})$. This suggests that higher levels of cardiorespiratory fitness are associated with lower levels of hs-CRP in young adults in the presence of high $\mathrm{BMI} \geq 25 \mathrm{~kg} / \mathrm{m}^{2}$ group. However, the cardiorespiratory fitness $\times$ BMI interaction term was not statistically significant on hs-CRP after adjustment for $\operatorname{sex} \times$ oral contraceptive interaction $(p=.127)$ in model 2 , Table 5 . This means that the sex $\times$ oral contraceptive interaction has an important confounding effect in relation to cardiorespiratory fitness, BMI and hs-CRP.

Table 6 shows the analysis of covariance (ANCOVA) to examine the association of cardiorespiratory fitness (continuous variable) $\times \mathrm{WC}$ (categorical variables) interaction

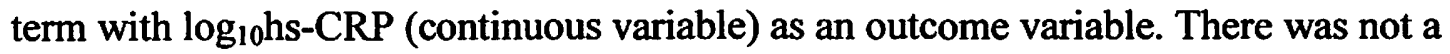
statistically significant cardiorespiratory fitness $\times$ WC interaction term on $\log _{10} h s-C R P$ (Model 1: adjusted $\mathrm{R}^{2}=.314, \mathrm{~F}(3,84)=14.283, p<.0001$; interaction term partial eta ${ }^{2}$ $=.012, \mathrm{~F}(1,84)=1.059, p=.306$ in Table 6$)$. Similarly, there was not a statistically 
significant cardiorespiratory fitness $\times \mathrm{WC}$ interaction term on $\log _{10} \mathrm{hs}-\mathrm{CRP}$ after adjustment for sex $\times$ oral contraceptive interaction in model 2 , Table 6 .

Interaction between Cardiorespiratory Fitness and Adiposity (BMI and WC) on $\log _{10} \mathrm{IL}-6$

The results of the analysis of covariance (ANCOVA) to examine the association of cardiorespiratory fitness (continuous variable) $\times$ BMI (categorical variables) interaction term with $\log _{10} \mathrm{IL}-6$ (continuous variable) as an outcome variable were shown in Table 7. Model 1 shows that there was not a statistically significant cardiorespiratory fitness $\times$ BMI interaction term on $\log _{10} \mathrm{IL}-6\left(\right.$ Model1: adjusted $\mathrm{R}^{2}=.190, \mathrm{~F}(3,83)=$ $7.705 p<.0001$; interaction term partial eta $\left.{ }^{2}=.033, \mathrm{~F}(1,83)=2.791, p=0.099\right)$. Similarly, the cardiorespiratory fitness $\times \mathrm{BMI}$ interaction term after adjustment for sex and education was not statistically significant on $\log _{10} \mathrm{IL}-6$ (Model 2: adjusted $\mathrm{R}^{2}=.240$, $\mathrm{F}(6,80)=5.528, p<.0001$; interaction term partial eta ${ }^{2}=.022, \mathrm{~F}(1,80)=1.820, p=$ $.181)$.

Table 8 shows the analysis of covariance (ANCOVA) to examine the association of cardiorespiratory fitness (continuous variable) $\times \mathrm{WC}$ (categorical variables) interaction term with $\log _{10} \mathrm{IL}-6$ (continuous variable) as the outcome variable. There was a statistically significant cardiorespiratory fitness $\times$ WC interaction term on $\log _{10} \mathrm{IL}-6$ (Model 1: adjusted $\mathrm{R}^{2}=.228, \mathrm{~F}(3,83)=9.456, p<.0001$; interaction term partial eta ${ }^{2}$ $=.080, \mathrm{~F}(1,83)=7.254, p=.009)$. The interaction effect is illustrated in Figure 3. For instance, young adults with $\mathrm{WC} \geq 86.4 \mathrm{~cm}$ and a high cardiorespiratory fitness $(55 \mathrm{~mL} / \mathrm{kg} \cdot \mathrm{min})$ had lower levels of IL-6 $(0.83 \mathrm{pg} / \mathrm{ml})$ compared with the IL-6 level $(1.83$ $\mathrm{pg} / \mathrm{ml}$ ) of young adults with $\mathrm{WC}<86.4 \mathrm{~cm}$ and a low cardiorespiratory fitness 
$(35 \mathrm{~mL} / \mathrm{kg} \cdot \mathrm{min})$. In contrast, young adults with $\mathrm{WC}<86.4 \mathrm{~cm}$ and a high cardiorespiratory fitness $(55 \mathrm{~mL} / \mathrm{kg} \cdot \mathrm{min})$ had a $0.84 \mathrm{IL}-6$ level, which was similar to the level of IL-6 $(0.88 \mathrm{pg} / \mathrm{ml})$ of young adults WC $<86.4 \mathrm{~cm}$ and a high cardiorespiratory fitness $(35 \mathrm{~mL} / \mathrm{kg} \cdot \mathrm{min})$. This significant interaction between cardiorespiratory fitness and WC on $\log _{10} \mathrm{IL}-6$ was sustained after adjustment for sex and education (Model 2: adjusted $\mathrm{R}^{2}=.258, \mathrm{~F}(6,80)=5.991, p<.0001$; interaction term partial eta ${ }^{2}=.056, \mathrm{~F}(1,80)=$ $4.730, p=.033)$. Thus, the association between cardiorespiratory fitness and $\log _{10} \mathrm{IL}-6$ depends on which levels of WC are being considered.

TNF- $\alpha$

There were no associations of cardiorespiratory fitness and adiposity (BMI and WC) with $\log _{10}$ TNF- $\alpha$ in young adults.

\section{Discussion}

The finding of the present study was that cardiorespiratory fitness was not significantly associated with hs-CRP after adjustment for BMI (WC) and sex $\times$ oral contraceptive interaction. Cardiorespiratory fitness was not significantly associated with IL-6 after adjustment for BMI, sex and education. However, higher levels of cardiorespiratory fitness were significantly and negatively associated with lower IL-6 levels after adjustment for WC, sex and education in young adults aged 20 to 34 years. For aim two, neither BMI nor WC significantly modified the strength of the associations of cardiorespiratory fitness with hs-CRP levels after adjustment for sex $\times$ oral contraceptives interaction. However, WC significantly modified the strength of the association of cardiorespiratory fitness with IL- 6 after adjustment for sex and education. Specifically, young adults with WC $\geq 86.4 \mathrm{~cm}$ (median split) and high levels of 
cardiorespiratory fitness had significantly lower levels of IL-6 compared with young adults with $\mathrm{WC} \geq 86.4 \mathrm{~cm}$ with lower levels of cardiorespiratory fitness. This provides evidence that cardiorespiratory fitness may act as an anti-inflammatory role in lowering levels of circulating IL-6 particularly in young adults with central adiposity.

In relation to the first aim, the findings of the associations of cardiorespiratory fitness and adiposity (BMI and WC) with hs-CRP of this present study were inconsistent with previous two studies (Kuo et al., 2007; Williams et al., 2005). Williams and colleagues reported that cardiorespiratory fitness levels are negatively associated with CRP levels after adjustment for BMI, systolic blood pressure, smoking, and combined oral contraceptive use in 26-year-old young adults $(p \leq 0.01)$. This inconsistent result could be explained by differences between the two samples in mean BMI. The means of BMI in the previous study were male $\left(25.2 \mathrm{~kg} / \mathrm{m}^{2}\right)$ and females $\left(24.8 \mathrm{~kg} / \mathrm{m}^{2}\right)$, whereas the means of BMI in the present study were males $\left(26.06 \pm 5.03 \mathrm{~kg} / \mathrm{m}^{2}\right)$ and females $(26.23 \pm$ $\left.6.81 \mathrm{~kg} \cdot \mathrm{m}^{2}\right)$. It has been reported that cardiorespiratory fitness is negatively associated with fatness (Martinez-Gomez et al., 2010). Moreover, higher levels of BMI are associated with high levels of hs-CRP (Choi, Joseph, \& Pilote, 2013). The other previous study by Kuo and colleagues also reported that a significantly negative association between cardiorespiratory fitness and CRP after adjustment for age, race, BMI category, cardiovascular risk factors and anti-inflammatory medication or CVD medications in 1438 adults aged 20-49 from the NHANES 1999-2002. This inconsistent result could be explained by statistically different adjustment for BMI variable. The previous study adjusted for BMI as categorical variables whereas this present study adjusted BMI as a continuous variable. This statistically different adjustment for adiposity (BMI or WC) 
could explain the different results. The findings of present study, however, were consistent with previous study by Martinez-Gomez et al. (2010), which showed that cardiorespiratory fitness was negatively associated with CRP, but this association did not remain statistically significant after adjustment for body fat in 192 adolescents aged 1317 years (Martinez-Gomez et al., 2010). Previous review by Hamer (2007) has also reported that high levels of fitness are associated with lower levels of inflammation, although the associations were mixed after adjusting for measures of fatness.

In terms of IL-6, no previous studies examined the association of cardiorespiratory fitness and adiposity (BMI and WC) with IL-6 in young adults aged 2034 years. To our best knowledge, the present study is the first study to examine the association of levels of cardiorespiratory fitness and adiposity (BMI and WC) with IL-6 levels particularly in young adult aged 20-34 years. The present study found that higher levels of cardiorespiratory fitness are significantly associated with lower levels of IL-6 in young adults when controlling for WC, sex and education.

In relation to the second aim, this present study is the first to examine the interactions of cardiorespiratory fitness and adiposity (BMI and WC) in relation to hsCRP and IL-6 levels in young adults. For circulating hs-CRP concentration, this present study did not find significant interactions between cardiorespiratory fitness and either BMI or WC levels with hs-CRP levels after adjustment for sex $\times$ oral contraceptive interaction in young adults. This finding may suggest that both cardiorespiratory fitness and adiposity (BMI and WC) could be independently related to hs-CRP. In a previous literature review including diverse populations by Hamer (2007) reported that both fitness and fatness were associated with inflammatory factors although the relative 
contributions of both may be dependent on sex, age, and disease status. Thus, both maintaining high levels of cardiorespiratory fitness and low levels of BMI and WC could be important factors for maintaining low hs-CRP levels in young adults.

For circulating IL-6 concentration, however, cardiorespiratory fitness $\times$ WC interaction was significantly associated with IL- 6 after adjustment for sex and education in young adults. This means that young adults with central adiposity may have lower levels of IL-6 if they have higher levels of cardiorespiratory fitness, indicating that higher levels of cardiorespiratory fitness may exert an anti-inflammatory effect and thereby protect against low-grade inflammation (Wilund, 2007). The mechanisms for the potential anti-inflammatory roles of fitness are not completely understood. The possible mechanisms have suggested that regular physical exercise could improve endotheliumdependent vasodilation by enhancing blood flow and shear stress, resulting in increased the bioavailability of nitric oxide production (Di Francescomarino, Sciartilli, Di Valerio, Di Baldassarre, \& Gallina, 2009). In contrast, this present study did not find a significant interaction between cardiorespiratory fitness and BMI on IL-6 after adjustment for sex and education. That is, both cardiorespiratory fitness and BMI could be independently related to IL-6 after adjustment for sex and education. No previous findings can be compared with findings of the present study in interaction between cardiorespiratory fitness and adiposity (measured by BMI and WC) on IL-6 in young adults.

Another important finding of this present study was that there was a significant interaction between cardiorespiratory fitness and WC with regards to IL-6, but there was no significant interaction between cardiorespiratory fitness and WC with regards to hsCRP. This difference may be explicated by differences in hs-CRP and IL- 6 secretion. IL- 
6 is produced in adipose tissue, and induces hepatic production of CRP (Shoelson, Herrero, \& Naaz, 2007). CRP is an acute-phase reactant synthesized mainly in the liver and is regulated by IL-6 levels (Clearfield, 2005). At rest, approximately $30 \%$ of circulating IL-6 is released from adipose tissue (Mohamed-All et al., 1997), and visceral adipose tissue secretes 2-3times more IL-6 than subcutaneous adipose tissue (Fried, Bunkin, \& Greenberg, 1998). This present study found that higher levels of cardiorespiratory fitness were significantly related to lower levels of IL-6 after adjustment for WC, sex and education. This study also found that higher levels of cardiorespiratory fitness were significantly associated with lower levels of IL-6, particularly young adults with $\mathrm{WC} \geq 86.4 \mathrm{~cm}$. Taken together, IL-6 levels influenced by visceral adipose tissue and higher levels of cardiorespiratory fitness are significantly related to reducing IL-6 levels in young adults with $\mathrm{WC} \geq 86.4 \mathrm{~cm}$.

This present study found that use of oral contraceptive was a significant confounding variable in relation to hs-CRP. Previous studies also have reported that hsCRP levels are significantly higher among oral contraceptive user versus non-users (Cauci et al., 2008; Dreon et al., 2003). The underlying mechanisms by which oral contraceptives induces higher levels of hs-CRP have not been fully clarified (Dreon et al., 2003). Previous investigations have suggested that exogenous estrogenic hormones may have directly modulate hepatic synthesis and therefore may affect pro-inflammatory pathways (van Rooijen, Hansson, Frostegard, Silveira, Hamsten, \& Bremme, 2006), but further investigations are required to clarify the pathways.

In relation to TNF- $\alpha$, this present study did not find any associations of cardiorespiratory fitness and BMI (WC) with TNF- $\alpha$ for aim land aim 2.This result is 
possibly due to low concentrations of TNF- $\alpha$ in young adults. In previous studies of the association between adiposity and TNF- $\alpha$, Wang and colleagues (2011) reported that TNF- $\alpha$ was not significantly related to BMI and percent body fat in university students, and this present study did not find any associations. In contrast, Moon et al and colleagues (2004) reported that TNF- $\alpha$ was significantly and positively associated with both BMI $(r=.346 ; p<.005)$ and WC $(r=.525 ; p<.001)$ in obese adolescents using a cross-sectional study.

There are several limitations in this present study. Firstly, it is the inability to establish causal relationships from data collected cross-sectional time frame. Secondly, a non-probability quota sampling method in university and community settings limited generalization of the findings of this study to young adults. Thirdly, indirect estimate of $\mathrm{VO}_{2 \max }$ through $\mathrm{HR}$ response to a submaximal single stage treadmill test estimated $\mathrm{VO}_{2 \max }$ instead of direct measurement of $\mathrm{VO}_{2 \max }$ through open circuit spirometry during maximal treadmill test (ACSM, 2010). Lastly, this present study found that 6 participants who had hs-CRP levels from 10.4 to $21.11 \mathrm{mg} / \mathrm{L}$, and these participants were not excluded from the data analysis. Albeit the American Heart Association (AHA)/Centers for Disease Control and Prevention (CDC) recommends that an hs-CRP level of $>10 \mathrm{mg} / \mathrm{L}$ should be repeated in 2 weeks due to the possible presence of an acute infection (Pearson et al., 2003), the 6 participants of this present study were unlikely to have acute infectious conditions. This present study very carefully assessed an acute infection or any trauma through inclusion and exclusion criteria and before blood testing. In addition, the 6 participants were all females that were overweight or obese (BMI from 28 to 44.1 $\mathrm{kg} / \mathrm{m}^{2}$ ). Except for one participant, they all had taken oral contraceptive medications. 
This suggests that more extreme levels of adiposity may be directly associated with acute chronic inflammation, and oral contraceptives also may contribute to higher levels of hsCRP. However, further study is needed to clarify this association. Moreover, exclusion of the 6 participants with an hs-CRP $>10 \mathrm{mg} / \mathrm{L}$ did not significantly change the findings (aim1 and 2) although the data were not shown in this paper.

The main strengths of this present study includes careful selection of participants using rigorous inclusion and exclusion criteria, and control of important confounders in relation to each biomarker. In addition, this present study extends previous studies by including inflammatory biomarkers in addition to CRP, such as IL-6 and TNF- $\alpha$ in young adults. Furthermore, central adiposity assessed by waist circumference regarding this association is included, which has not been examined in young adults previously.

Prospective studies are needed to ascertain the influences of cardiorespiratory fitness and adiposity on inflammatory biomarkers during young adulthood. Exercise intervention studies for improving cardiorespiratory fitness and weight reduction are also warranted to reduce hs-CRP and IL-6 and to improve cardiovascular health in young adults. Moreover, research is needed to investigate the associations of cardiorespiratory fitness and adiposity with TNF- $\alpha$ in overweight and obese young adults.

In conclusion, cardiorespiratory fitness is significantly and negatively associated with IL-6 in young adults aged 20-34 years after adjustment for WC, sex, and education. Moreover, there is a significant interaction between cardiorespiratory fitness and WC in predicting IL-6 levels after adjustment for sex and education in young adults aged 20-34 years old. Therefore, cardiorespiratory fitness may decrease risk of atherosclerosis, CVD events, and CVD by reducing inflammatory biomarkers. Further studies are warranted to 
determine if experimentally induced increases in cardiorespiratory fitness reduce inflammatory markers in young adults. Longitudinal studies are needed to understand the inflammatory mechanisms related to cardiorespiratory fitness and adiposity, and its influence on cardiovascular disease risk in young adults. 


\section{References}

American College of Sports Medicine (2010). Guidelines for exercise testing and prescription. 8th ed. Philadelphia, PA: Lippincott, Williams \& Wilkins.

Antuna-Puente, B., Feve, B., Fellahi, S., \& Bastard, J. P. (2008). Adipokines: The missing link between insulin resistance and obesity. Diabetes $\&$ Metabolism, 34(1), 2-11. doi:10.1016/j.diabet.2007.09.004

Bajpai, A., Goyal, A., \& Sperling, L. (2010). Should we measure C-reactive protein on earth or just on JUPITER? Clinical Cardiology, 33(4), 190-198. doi: $10.1002 /$ clc.20681

Blair, S. N., Kohl, H. W.,3rd, Barlow, C. E., Paffenbarger, R. S.,Jr, Gibbons, L. W., \& Macera, C. A. (1995). Changes in physical fitness and all-cause mortality. A prospective study of healthy and unhealthy men. JAMA : The Journal of the American Medical Association, 273(14), 1093-1098.

Borg, G. (1970). Perceived exertion as an indicator of somatic stress. Scandinavian Journal of Rehabilitation Medicine, 2(2), 92-98.

Brooks, G. C., Blaha, M. J., \& Blumenthal, R. S. (2010). Relation of C-reactive protein to abdominal adiposity. The American Journal of Cardiology, 106(1), 56-61. doi:10.1016/j.amjcard.2010.02.017

Buckley, D. I., Fu, R., Freeman, M., Rogers, K., \& Helfand, M. (2009). C-reactive protein as a risk factor for coronary heart disease: A systematic review and metaanalyses for the U.S. preventive services task force. Annals of Internal Medicine, 151(7), 483-495. doi:151/7/483 [pii] 
Calabro, P., Golia, E., \& Yeh, E. T. (2009). CRP and the risk of atherosclerotic events. Seminars in Immunopathology, 31(1), 79-94. doi: 10.1007/s00281-009-0149-4

Caspersen, C. J., Powell, K. E., \& Christenson, G. (1985). Physical activity, exercise and physical fitness: Definitions and distinctions for health-related research. Public Health Reports, 100(2), 126-131.

Cauci, S., Di Santolo, M., Culhane, J. F., Stel, G., Gonano, F., \& Guaschino, S. (2008). Effects of third-generation oral contraceptives on high-sensitivity C-reactive protein and homocysteine in young women. Obstetrics and Gynecology, 111(4), 857-864. doi:10.1097/AOG.0b013e31816a2476 [doi]

Choi, J., Joseph, L., \& Pilote, L. (2013). Obesity and C-reactive protein in various populations: A systematic review and meta-analysis. Obesity Reviews, 14(3), 232244. doi:10.1111/obr.12003

Church, T. S., Barlow, C. E., Earnest, C. P., Kampert, J. B., Priest, E. L., \& Blair, S. N. (2002). Associations between cardiorespiratory fitness and C-reactive protein in men. Arteriosclerosis, Thrombosis, and Vascular Biology, 22(11), 1869-1876.

Clearfield, M. B. (2005). C-reactive protein: A new risk assessment tool for cardiovascular disease. The Journal of the American Osteopathic Association, 105(9), 409-416.

Cohen, J. (1998). Statistical power analysis for the behavioral sciences $\left(2^{\text {nd }}\right.$ ed.). Hills dale, NJ: Eribaum.

Di Francescomarino, S., Sciartilli, A., Di Valerio, V., Di Baldassarre, A., \& Gallina, S. (2009). The effect of physical exercise on endothelial function. Sports Medicine 
(Auckland, N.Z.), 39(10), 797-812. doi:10.2165/11317750-000000000-00000 [doi]

Dreon, D. M., Slavin, J. L., \& Phinney, S. D. (2003). Oral contraceptive use and increased plasma concentration of C-reactive protein. Life Sciences, 73(10), 1245-1252. doi:S0024320503004259 [pii]

Ebbeling, C. B., Ward, A., Puleo, E. M., Widrick, J., \& Rippe, J. M. (1991).

Development of a single-stage submaximal treadmill walking test. Medicine and Science in Sports and Exercise, 23(8), 966-973.

Escobar-Morreale, H. F., Luque-Ramírez, M., \& González, F. (2011). Circulating inflammatory markers in polycystic ovary syndrome: A systematic review and meta-analysis. Fertility and Sterility, 95(3),1048-1058.e2. doi:10.1016/j.fertnstert.2010.11.036

Ferri, C., Croce, G., Cofini, V., De Berardinis, G., Grassi, D., Casale, R., . . Desideri, G. (2007). C-reactive protein: Interaction with the vascular endothelium and possible role in human atherosclerosis. Current Pharmaceutical Design, 13(16), 16311645.

Ferrucci, L., Corsi, A., Lauretani, F., Bandinelli, S., Bartali, B., Taub, D. D., . . Longo, D. L. (2005). The origins of age-related proinflammatory state. Blood, 105(6), 2294-2299. doi:10.1182/blood-2004-07-2599

Franks, P. W., Hanson, R. L., Knowler, W. C., Sievers, M. L., Bennett, P. H., \& Looker, H. C. (2010). Childhood obesity, other cardiovascular risk factors, and premature death. The New England Journal of Medicine, 362(6), 485-493. doi:10.1056/NEJMoa0904130 
Fried, S. K., Bunkin, D. A., \& Greenberg, A. S. (1998). Omental and subcutaneous adipose tissues of obese subjects release interleukin-6: Depot difference and regulation by glucocorticoid. The Journal of Clinical Endocrinology and Metabolism, 83(3), 847-850. doi:10.1210/jcem.83.3.4660 [doi]

Friedman, E. M., \& Herd, P. (2010). Income, education, and inflammation: Differential associations in a national probability sample (the MIDUS study). Psychosomatic Medicine, 72(3), 290-300. doi:10.1097/PSY.0b013e3181cfe4c2;

10.1097/PSY.0b013e3181cfe4c2

Gaskins, A. J., Wilchesky, M., Mumford, S. L., Whitcomb, B. W., Browne, R. W., Wactawski-Wende, J., . . . Schisterman, E. F. (2012). Endogenous reproductive hormones and C-reactive protein across the menstrual cycle: The BioCycle study. American Journal of Epidemiology, 175(5), 423-431.

Go, A. S., Mozaffarian, D., Roger, V. L., Benjamin, E. J., Berry, J. D., Borden, W. B., . . American Heart Association Statistics Committee and Stroke Statistics Subcommittee. (2013). Heart disease and stroke statistics--2013 update: A report from the American Heart Association. Circulation, 127(1), e6-e245. doi: 10.1161/CIR.0b013e31828124ad; 10.1161/CIR.0b013e31828124ad

Haddy, N., Sass, C., Droesch, S., Zaiou, M., Siest, G., Ponthieux, A., . . Visvikis, S. (2003). IL-6, TNF- $\alpha$ and atherosclerosis risk indicators in a healthy family population: The STANISLAS cohort. Atherosclerosis, 170(2), 277-283. doi: $10.1016 / \mathrm{S} 0021-9150(03) 00287-9$

Hamer, M. (2007). The relative influences of fitness and fatness on inflammatory factors. Preventive Medicine, 44(1), 3-11. 
Heyward, H. V. (2010). Advanced fitness assessment and exercise prescription. $6^{\text {th }}$ ed. Champaign, IL; Human Kinetics.

Isasi, C. R., Deckelbaum, R. J., Tracy, R. P., Starc, T. J., Berglund, L., \& Shea, S. (2003). Physical fitness and C-reactive protein level in children and young adults: The Columbia university BioMarkers study. Pediatrics, 111(2), 332-338.

Kelley-Hedgepeth, A., Lloyd-Jones, D. M., Colvin, A., Matthews, K. A., Johnston, J., Sowers, M. R., . . Chae, C. U. (2008). Ethnic differences in C-reactive protein concentrations. Clinical Chemistry, 54(6), 1027-1037.

Kullo, I. J., Khaleghi, M., \& Hensrud, D. D. (2007). Markers of inflammation are inversely associated with VO2 max in asymptomatic men. Journal of Applied Physiology (Bethesda, Md.: 1985), 102(4), 1374-1379. doi:01028.2006 [pii]

Kuo, H. K., Yen, C. J., Chen, J. H., Yu, Y. H., \& Bean, J. F. (2007). Association of cardiorespiratory fitness and levels of C-reactive protein: Data from the National Health and Nutrition Examination Survey 1999-2002. International Journal of Cardiology, 114(1), 28-33. doi:10.1016/j.ijcard.2005.11.110

Libby, P., Ridker, P. M., \& Hansson, G. K. (2009). Inflammation in atherosclerosis: From pathophysiology to practice. Journal of the American College of Cardiology, 54(23), 2129-2138. doi:10.1016/j.jacc.2009.09.009

Loria, C. M., Liu, K., Lewis, C. E., Hulley, S. B., Sidney, S., Schreiner, P. J., . . Detrano, R. (2007). Early adult risk factor levels and subsequent coronary artery calcification: The CARDIA study. Journal of the American College of Cardiology, 49(20), 2013-2020. doi:10.1016/j.jacc.2007.03.009 
Martinez-Gomez, D., Eisenmann, J. C., Wärnberg, J., Gomez-Martinez, S., Veses, A., Veiga, O. L., \& Marcos, A. (2010). Associations of physical activity, cardiorespiratory fitness and fatness with low-grade inflammation in adolescents: The AFINOS study. International Journal of Obesity, 34(10), 1501-1507.

Mohamed-Ali, V., Goodrick, S., Rawesh, A., Katz, D. R., Miles, J. M., Yudkin, J. S., . . . Coppack, S. W. (1997). Subcutaneous adipose tissue releases interleukin-6, but not tumor necrosis factor-alpha, in vivo. The Journal of Clinical Endocrinology and Metabolism, 82(12), 4196-4200. doi:10.1210/jcem.82.12.4450 [doi]

Moon, Y. S., Kim, D. H., \& Song, D. K. (2004). Serum tumor necrosis factor-alpha levels and components of the metabolic syndrome in obese adolescents. Metabolism: Clinical \& Experimental, 53(7), 863-867. doi: 10.1016/j.metabol.2004.02.007

National Health and Nutrition Examination Survey (NHANES) (2009). Anthropometric procedures manual. Center for Disease Prevention. Retrieved from www.cdc.gov/nchs/data/nhanes/nhanes_03_04/BM.pdf

O'Connor, M. F., Bower, J. E., Cho, H. J., Creswell, J. D., Dimitrov, S., Hamby, M. E., ... Irwin, M. R. (2009). To assess, to control, to exclude: Effects of biobehavioral factors on circulating inflammatory markers. Brain, Behavior, \& Immunity, 23(7), 887-897. Retrieved from http://dx.doi.org/10.1016/j.bbi.2009.04.005

Paalani, M., Lee, J. W., Haddad, E., \& Tonstad, S. (2011). Determinants of inflammatory markers in a bi-ethnic population. Ethnicity \& Disease, 21(2), 142-149. 
Pearson, T. A., Mensah, G. A., Alexander, R. W., Anderson, J. L., Cannon, R. O.,3rd, Criqui, M., ... American Heart Association. (2003). Markers of inflammation and cardiovascular disease: Application to clinical and public health practice: A statement for healthcare professionals from the centers for disease control and prevention and the American Heart Association. Circulation, 107(3), 499-511.

Petersen, A. M., \& Pedersen, B. K. (2005). The anti-inflammatory effect of exercise. Journal of Applied Physiology, 98(4), 1154-1162.

doi:10.1152/japplphysiol.00164.2004

Ridker, P. M. (2003). Clinical application of C-reactive protein for cardiovascular disease detection and prevention. Circulation, 107(3), 363-369.

Ridker, P. M. (2001). High-sensitivity C-reactive protein: Potential adjunct for global risk assessment in the primary prevention of cardiovascular disease. Circulation, 103(13), 1813-1818.

Ridker, P. M, Rifai, N, Stampfer, M. J., \& Hennekens, C. H. (2000). Plasma concentration of interleukin- 6 and the risk of future myocardial infarction among apparently healthy men. Circulation, 101(15),1767-1772

Schuett, H., Luchtefeld, M., Grothusen, C., Grote, K., \& Schieffer, B. (2009). How much is too much? interleukin-6 and its signalling in atherosclerosis. Thrombosis and Haemostasis, 102(2), 215-222. doi:10.1160/TH09-05-0297

Shoelson, S. E., Herrero, L., \& Naaz, A. (2007). Obesity, inflammation, and insulin resistance. Gastroenterology, 132(6), 2169-2180. doi:http://dx.doi.org.www5.sph.uth.tmc.edu:2048/10.1053/j.gastro.2007.03.059 
Skoog, T., Dichtl, W., Boquist, S., Skoglund-Andersson, C., Karpe, F., Tang, R., . . . Hamsten, A. (2002). Plasma tumour necrosis factor-alpha and early carotid atherosclerosis in healthy middle-aged men. European Heart Journal, 23(5), 376383. doi:10.1053/euhj.2001.2805 [doi]

Stevens, J., McClain, J. E., \& Truesdale, K. P. (2008). Selection of measures in epidemiologic studies of the consequences of obesity. International Journal of Obesity (2005), 32 Suppl 3, S60-6. doi:10.1038/ijo.2008.88

van Rooijen, M., Hansson, L. O., Frostegard, J., Silveira, A., Hamsten, A., \& Bremme, K. (2006). Treatment with combined oral contraceptives induces a rise in serum Creactive protein in the absence of a general inflammatory response. Journal of Thrombosis and Haemostasis : JTH, 4(1), 77-82. doi:JTH1690 [pii]

Wang, S., Reed, D. B., Goli, S., \& Goswami, D. (2011). Blood leptin and C-reactive protein provide more sensitive assessment than blood lipids and other inflammatory biomarkers in overweight university students. Nutrition Research, 31(8), 586-593. doi: 10.1016/j.nutres.2011.07.006

Williams, M. J., Milne, B. J., Hancox, R. J., \& Poulton, R. (2005). C-reactive protein and cardiorespiratory fitness in young adults. European Journal of Cardiovascular Prevention and Rehabilitation: Official Journal of the European Society of Cardiology, Working Groups on Epidemiology \& Prevention and Cardiac Rehabilitation and Exercise Physiology, 12(3), 216-220.

Williams, M. J. A., Williams, S. M., \& Poulton, R. (2006). Breast feeding is related to C reactive protein concentration in adult women. Journal of Epidemiology and Community Health, 60(2), 146-148, doi: 10.1136/jech.2005.039222 
Wilund, K. (2007). Is the anti-inflammatory effect of regular exercise responsible for reduced cardiovascular disease? Clinical Science; 112(11-12): 543-555. 


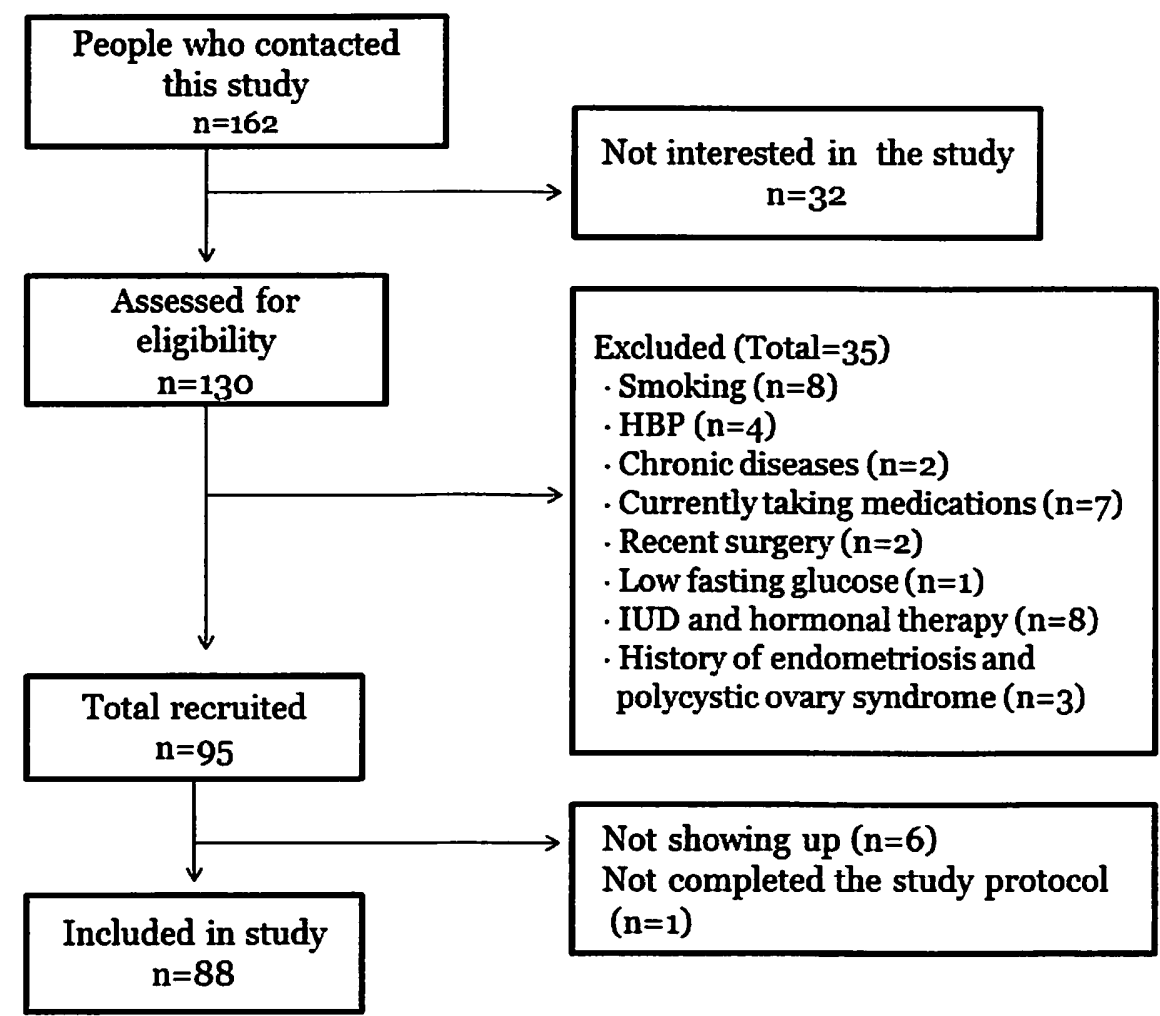

Figure1. Young adult recruitment flow diagram 
Table 1

Participant characteristics

\begin{tabular}{|c|c|c|}
\hline & \multicolumn{2}{|c|}{ All $(\mathrm{N}=88)$} \\
\hline & $\mathrm{n}$ & $\%$ or Mean $\pm \mathrm{SD}$ \\
\hline Age (years) & 88 & $25.97 \pm 3.84$ \\
\hline \multicolumn{3}{|l|}{ Sex } \\
\hline Male & 43 & $\begin{array}{l}48.9 \% \\
26.30 \pm 3.90\end{array}$ \\
\hline Female & 45 & $\begin{array}{l}51.1 \% \\
25.66 \pm 3.80\end{array}$ \\
\hline \multicolumn{3}{|l|}{ Ethnicity } \\
\hline Caucasian & 24 & $27.3 \%$ \\
\hline African American & 18 & $20.5 \%$ \\
\hline Hispanic & 19 & $21.6 \%$ \\
\hline Asian & 20 & $22.7 \%$ \\
\hline Mixed Race & 7 & $8.0 \%$ \\
\hline \multicolumn{3}{|l|}{ Marital status } \\
\hline $\begin{array}{l}\text { Married or living } \\
\text { with partner }\end{array}$ & 18 & $20.5 \%$ \\
\hline Single & 70 & $79.5 \%$ \\
\hline \multicolumn{3}{|l|}{ Occupation } \\
\hline Employee & 16 & $18.2 \%$ \\
\hline Doctoral student & 9 & $10.1 \%$ \\
\hline Master student & 28 & $31.8 \%$ \\
\hline College student & 33 & $37.5 \%$ \\
\hline Other & 2 & $2.3 \%$ \\
\hline \multicolumn{3}{|l|}{ Education } \\
\hline Graduate degree & 17 & $19.3 \%$ \\
\hline Undergraduate degree & 49 & $55.7 \%$ \\
\hline High school degree & 22 & $25.0 \%$ \\
\hline Oral contraceptives & 45 & \\
\hline Yes & 12 & $26.6 \%$ \\
\hline No & 33 & $73.4 \%$ \\
\hline
\end{tabular}


Table 2

Descriptive statistics for anthropometric and inflammatory biomarkers in young adult aged 20-34 years $(N=88)$

\begin{tabular}{|c|c|c|c|c|c|c|}
\hline & \multicolumn{2}{|c|}{ All $(\mathrm{N}=88)$} & \multicolumn{2}{|c|}{ Males $(n=43)$} & \multicolumn{2}{|c|}{ Females $(n=45)$} \\
\hline & Mean \pm SD (Range) & $\mathrm{n}(\%)$ & Mean \pm SD (Range) & $\mathrm{n}(\%)$ & $\begin{array}{l}\text { Mean } \pm \text { SD } \\
\text { (Range) }\end{array}$ & $\mathrm{n}(\%)$ \\
\hline $\begin{array}{l}\text { Height }(\mathrm{cm}) \\
\text { Weight }(\mathrm{kg})\end{array}$ & $\begin{array}{l}169.93 \pm 9.42 \\
75.66 \pm 18.76\end{array}$ & & $\begin{array}{l}176.22 \pm 7.49 \\
81.00 \pm 17.52\end{array}$ & & $\begin{array}{l}163.93 \pm 6.83 \\
70.55 \pm 18.68\end{array}$ & \\
\hline $\begin{array}{l}\text { BMI }\left(\mathrm{kg} / \mathrm{m}^{2}\right) \\
\text { Normal weight }<25 \\
\text { Overweight/Obese } \geq 25\end{array}$ & $\begin{array}{l}26.15 \pm 5.97 \\
21.90 \pm 1.74 \\
30.39 \pm 5.69\end{array}$ & $\begin{array}{l}44(50) \\
44(50)\end{array}$ & $\begin{array}{l}26.06 \pm 5.03 \\
22.42 \pm 1.51 \\
29.53 \pm 4.76\end{array}$ & $\begin{array}{l}21(48.8) \\
22(51.2)\end{array}$ & $\begin{array}{l}26.23 \pm 6.81 \\
21.43 \pm 1.83 \\
31.25 \pm 6.50\end{array}$ & $\begin{array}{l}23(51.1) \\
22(48.9)\end{array}$ \\
\hline $\begin{array}{l}\text { WC }(\mathrm{cm}) \\
<86.4 \\
\geq 86.4\end{array}$ & $\begin{array}{l}90.06 \pm 14.30 \\
80.01 \pm 4.78 \\
100.11 \pm 13.59\end{array}$ & $\begin{array}{l}44(50) \\
44(50)\end{array}$ & $\begin{array}{l}91.03 \pm 12.96 \\
81.93 \pm 4.33 \\
97.59 \pm 13.18\end{array}$ & $\begin{array}{l}18(41.9) \\
25(58.1)\end{array}$ & $\begin{array}{l}89.12 \pm 15.57 \\
78.67 \pm 4.69 \\
103.42 \pm 13.74\end{array}$ & $\begin{array}{l}26(57.8) \\
19(42.2)\end{array}$ \\
\hline $\begin{array}{l}\mathrm{SBP}(\mathrm{mm} \mathrm{Hg}) \\
\mathrm{DBP}(\mathrm{mm} \mathrm{Hg}) \\
\text { HR (per min) }\end{array}$ & $\begin{array}{l}114.31 \pm 9.18 \\
73.23 \pm 8.66 \\
68.72 \pm 11.00\end{array}$ & & $\begin{array}{l}119.59 \pm 5.89 \\
74.97 \pm 7.92 \\
67.14 \pm 9.73\end{array}$ & & $\begin{array}{l}109.26 \pm 8.95 \\
71.57 \pm 9.08 \\
70.22 \pm 12.00\end{array}$ & \\
\hline $\begin{array}{l}\mathrm{CRF} \\
\left(\mathrm{VO}_{2} \max (\mathrm{mL} / \mathrm{kg} \cdot \mathrm{min})\right) \\
\mathrm{hs}-\mathrm{CRP}(\mathrm{mg} / \mathrm{L})\end{array}$ & $\begin{array}{l}45.72 \pm 9.03 \\
(15.42-59.84) \\
2.16 \pm 3.81 \\
(0.067-21.11)\end{array}$ & $\begin{array}{l}88 \\
88\end{array}$ & $\begin{array}{l}52.27 \pm 5.06 \\
(38.42-59.84) \\
1.35 \pm 1.98 \\
(0.067-9.41)\end{array}$ & $\begin{array}{l}43 \\
43\end{array}$ & $\begin{array}{l}39.47 \pm 7.41 \\
(15.42-56.53) \\
2.69 \pm 4.87 \\
(0.085-21.11)\end{array}$ & $\begin{array}{l}45 \\
45\end{array}$ \\
\hline IL-6 (pg/ml) & $\begin{array}{l}1.26 \pm 1.17 \\
(0.33-8.69)\end{array}$ & 87 & $\begin{array}{l}1.07 \pm 0.68 \\
(0.40-3.70)\end{array}$ & 43 & $\begin{array}{l}1.45 \pm 1.48 \\
(0.33-8.69)\end{array}$ & 44 \\
\hline TNF- $\alpha(\mathrm{pg} / \mathrm{ml})$ & $1.09 \pm 1.19$ & 88 & $1.16 \pm 0.99$ & 43 & $1.03 \pm 1.36$ & 45 \\
\hline
\end{tabular}


Abbreviations: CRF, cardiorespiratory fitness; BMI, body mass index; WC, waist circumference; CRP, c-reactive protein; IL-6, interleukin-6; TNF- $\alpha$, tumor necrosis factor-alpha; SBP, systolic blood pressure; DBP, diastolic blood pressure; HR, heart rate.

Note: $W C$ was divided into two categories based on the $50^{\text {th }}$ percentile (median value $=86.4 \mathrm{~cm}$ ) 
Table 3

Multiple linear regression of cardiorespiratory fitness and adiposity with $\log _{10} h s-C R P(N=88)$

\begin{tabular}{|c|c|c|c|c|c|c|c|c|c|}
\hline \multirow{4}{*}{ Predictor variables } & \multicolumn{9}{|c|}{ Outcomes } \\
\hline & \multicolumn{9}{|c|}{$\log _{10} \mathrm{hs}-\mathrm{CRP}(\mathrm{mg} / \mathrm{L})$} \\
\hline & \multicolumn{4}{|c|}{ Models } & \multicolumn{5}{|c|}{ Coefficients } \\
\hline & $R^{2}$ & $\operatorname{adj} R^{2}$ & $\mathbf{F}$ & $p$ & $B$ & $S E B$ & $\beta$ & $\mathrm{t}$ & $p$ \\
\hline Model 1 & .324 & .300 & 13.430 & .000 & & & & & \\
\hline Intercept & & & & & 2.028 & .457 & & 4.435 & .000 \\
\hline $\mathrm{CRF}(\mathrm{mL} / \mathrm{kg} \cdot \mathrm{min})$ & & & & & -.042 & .009 & -.639 & -4.920 & .000 \\
\hline $\mathrm{Sex} \times \mathrm{OC}$ & & & & & & & & & .000 \\
\hline Male (ref) & & & & & & & & & \\
\hline Female (non-OC) & & & & & -.577 & .166 & -.468 & -3.475 & .001 \\
\hline Female (OC) & & & & & .194 & .186 & .111 & 1.040 & .301 \\
\hline Model 2 & .455 & .429 & 17.324 & .000 & & & & & \\
\hline Intercept & & & & & -.838 & .763 & & -1.098 & .275 \\
\hline $\mathrm{CRF}(\mathrm{mL} / \mathrm{kg} \cdot \mathrm{min})$ & & & & & -.012 & .010 & -.178 & -1.137 & .259 \\
\hline BMI $\left(\mathrm{kg} / \mathrm{m}^{2}\right)$ & & & & & .049 & .011 & .484 & 4.464 & .000 \\
\hline $\mathrm{Sex} \times \mathrm{OC}$ & & & & & & & & & .001 \\
\hline Male (ref) & & & & & & & & & \\
\hline Female (non-OC) & & & & & -.144 & .178 & -.117 & -.806 & .423 \\
\hline Female (OC) & & & & & .443 & .177 & .255 & 2.498 & .014 \\
\hline Model 3 & .445 & .418 & 16.641 & .000 & & & & & \\
\hline Intercept & & & & & -1.253 & .877 & & -1.429 & .157 \\
\hline $\mathrm{CRF}\left(\mathrm{mL} / \mathrm{kg}^{-1} \cdot \mathrm{min}^{-1}\right)$ & & & & & -.013 & .010 & -.202 & -1.291 & .200 \\
\hline $\mathrm{WC}(\mathrm{cm})$ & & & & & .019 & .005 & .462 & 4.252 & .000 \\
\hline Sex $\times$ OC & & & & & & & & & .001 \\
\hline Male (ref) & & & & & & & & & \\
\hline Female (non-OC) & & & & & -.125 & .185 & -.102 & -.679 & .499 \\
\hline Female (OC) & & & & & .484 & .183 & .279 & 2.647 & .010 \\
\hline $\begin{array}{l}\text { Abbreviations: CRF, ca } \\
\text { hs-CRP, high sensitive } \\
\text { standard error } ; \beta \text {, stand } \\
\text { Model 1: Multiple linea } \\
\text { oral contraceptive inter } \\
\text { Model } 2: \text { Multiple linea } \\
\text { and sex } \times \text { oral contrace } \\
\text { Model } 3: \text { Multiple linea } \\
\text { and sex } \times \text { oral contrace } \\
\text { Note: hs-CRP was trans } \\
\text { variables }\end{array}$ & $\begin{array}{l}\text { rdized } \\
\text { regres } \\
\text { ction to } \\
\text { regres } \\
\text { tive in } \\
\text { regres } \\
\text { tive in } \\
\text { cormed }\end{array}$ & $\begin{array}{l}\text { iratory } \\
\text { ve prote } \\
\text { coeffici } \\
\text { sion pre } \\
\text { rm } \\
\text { sion pre } \\
\text { eraction } \\
\text { sion pre } \\
\text { eraction } \\
\text { into log }\end{array}$ & $\begin{array}{l}\text { itness; Bl } \\
\text { in; adj, ad } \\
\text { nts; OC, } \\
\text { licting Cl } \\
\text { licting Cl } \\
\text { term } \\
\text { licting CI } \\
\text { term } \\
\text { ohs-CRP }\end{array}$ & $\begin{array}{l}\text { II, bod } \\
\text { usted; } \\
\text { oral co } \\
\text { F from } \\
\text { F from } \\
\text { F from } \\
\text { mg/L) }\end{array}$ & $\begin{array}{l}\text { ceptives } \\
\mathrm{g}_{10} \mathrm{hs}-\mathrm{CR} \\
\mathrm{g}_{10} \mathrm{hs}-\mathrm{CR} \\
\mathrm{g}_{10} \mathrm{hs}-\mathrm{CR} \\
\text { RF, BMl }\end{array}$ & $\begin{array}{l}\text { WC, n } \\
\text { ized co } \\
\text { ef, refe } \\
\text { after a } \\
\text { after a }\end{array}$ & $\begin{array}{l}\text { ist circu } \\
\text { ficients } \\
\text { nce. } \\
\text { ustment } \\
\text { ustment }\end{array}$ & $\begin{array}{l}\text { ference; } \\
\text { SE, } \\
\text { or sex } \times \\
\text { or BMI } \\
\text { or WC }\end{array}$ & \\
\hline
\end{tabular}


Table 4

Multiple linear regression of cardiorespiratory fitness and adiposity with $\log _{10} I L-6(N=87)$

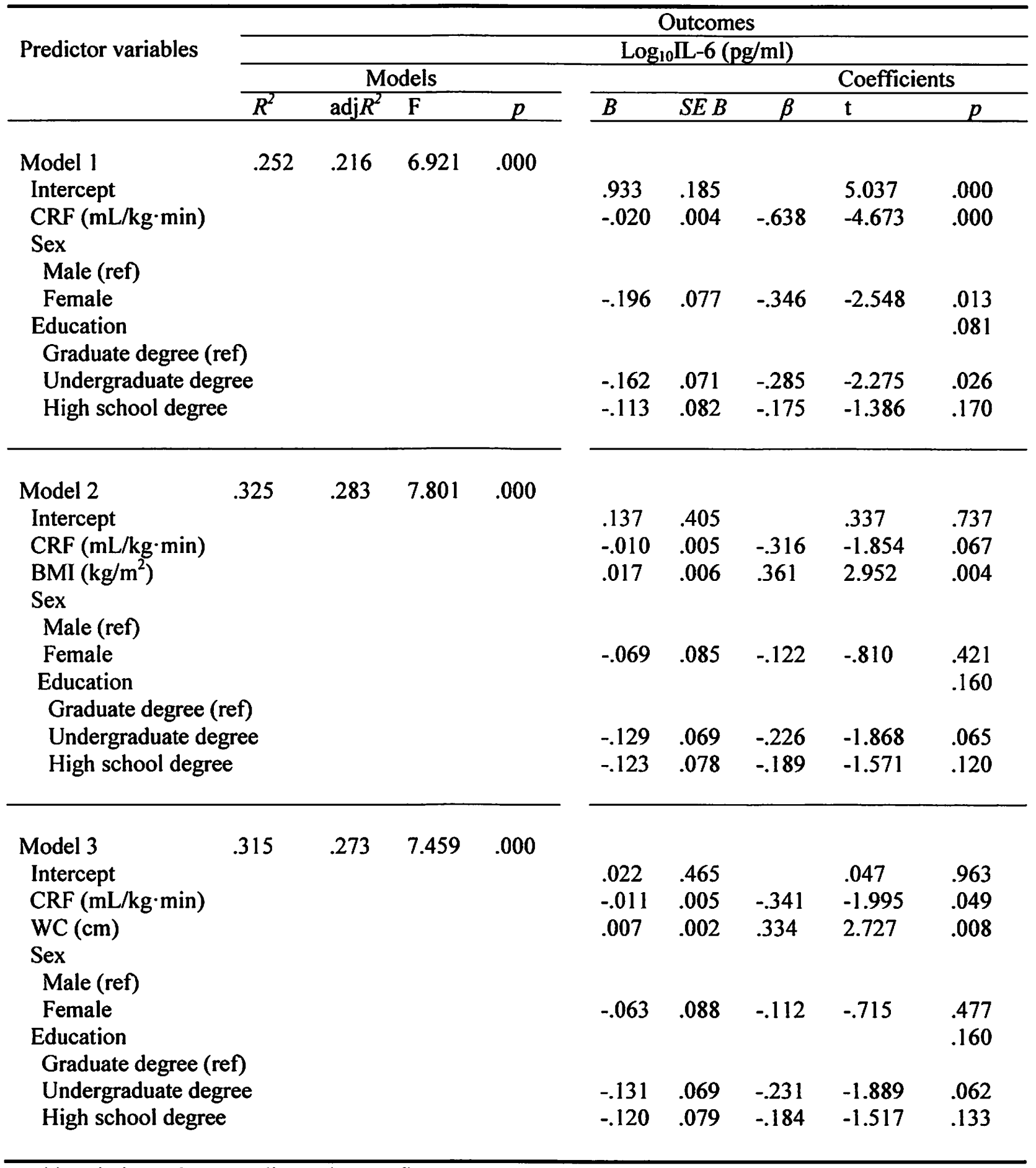

Abbreviations: CRF, cardiorespiratory fitness; BMI, body mass index; WC, waist circumference; IL-6, interleukin-6; adj, adjusted; B, unstandardized coefficients; SE, standard error; $\beta$, standardized coefficients; ref, reference. 
Model 1: Multiple linear regression predicting CRF from $\log _{10}$ IL-6 after adjustment for sex and education

Model 2: Multiple linear regression predicting CRF from $\log _{10} \mathrm{IL}-6$ after adjustment for BMI, sex and education

Model 3: Multiple linear regression predicting CRF from $\log _{10} \mathrm{IL}-6$ after adjustment for WC, sex and education

Note: IL-6 (pg/mL) was transformed into $\log _{10} \mathrm{IL}-6(\mathrm{pg} / \mathrm{mL})$; CRF, BMI, and WC, continuous variables 
Table 5

Analysis of covariance for $\log _{10} h s-C R P$ as an interaction of CRF and $B M I(N=88)$

\begin{tabular}{|c|c|c|c|c|c|c|c|c|c|}
\hline Predictor variables & $R^{2}$ & $\operatorname{adj} R^{2}$ & $p$ & $B$ & $\begin{array}{l}S E \\
B\end{array}$ & df & $\mathbf{F}$ & $p$ & $\begin{array}{l}\text { Partial } \\
\text { eta }^{2}\end{array}$ \\
\hline Model 1 & .255 & .229 & .000 & & & 3 & 9.607 & .000 & .255 \\
\hline Intercept & & & & -.235 & .506 & 1 & 3.630 & .060 & .041 \\
\hline $\mathrm{CRF}(\mathrm{mL} / \mathrm{kg} \cdot \mathrm{min})$ & & & & -.002 & .010 & 1 & 5.802 & .018 & .065 \\
\hline \multicolumn{10}{|c|}{$\mathrm{BMI}\left(<25 \mathrm{~kg} / \mathrm{m}^{2}\right)($ ref $)$} \\
\hline \multirow{2}{*}{\multicolumn{4}{|c|}{$\begin{array}{l}\mathrm{BMI}\left(\geq 25 \mathrm{~kg} / \mathrm{m}^{2}\right) \\
\mathrm{CRF}(\mathrm{mL} / \mathrm{kg} \cdot \mathrm{min}) \times \mathrm{BMI}\left(\geq 25 \mathrm{~kg} / \mathrm{m}^{2}\right)\end{array}$}} & 1.664 & .626 & 1 & 7.061 & .009 & .078 \\
\hline & & & & -.028 & .013 & 1 & 4.553 & .036 & .051 \\
\hline Model 2 & .385 & .348 & .000 & & & 5 & 10.280 & .000 & .385 \\
\hline Intercept & & & & .753 & .666 & 1 & 9.257 & .003 & .101 \\
\hline $\mathrm{CRF}(\mathrm{mL} / \mathrm{kg} \cdot \mathrm{min})$ & & & & -.020 & .013 & 1 & 9.802 & .002 & .107 \\
\hline \multicolumn{10}{|c|}{$\mathrm{BMI}\left(<25 \mathrm{~kg} / \mathrm{m}^{2}\right)(\mathrm{ref})$} \\
\hline $\mathrm{BMI}\left(\geq 25 \mathrm{~kg} / \mathrm{m}^{2}\right)$ & & & & 1.172 & .594 & 1 & 3.894 & .052 & .045 \\
\hline $\mathrm{CRF}(\mathrm{mL} / \mathrm{kg} \cdot \mathrm{min})$ & $\geq 25 \mathrm{~kg}$ & & & -.019 & .012 & 1 & 2.379 & .127 & .028 \\
\hline \multicolumn{4}{|c|}{ Sex $\times$ OC } & & & 2 & 8.662 & .000 & .174 \\
\hline \multicolumn{10}{|l|}{ Male (ref) } \\
\hline Female (non-OC & & & & -.400 & .172 & & & & \\
\hline Female (OC) & & & & .293 & .184 & & & & \\
\hline
\end{tabular}

Abbreviations: CRF, cardiorespiratory fitness; BMI, body mass index; hs-CRP; high sensitive Creactive protein; oral contraceptives, $\mathrm{OC}$; adj, adjusted; $\mathrm{B}$, unstandardized coefficients; SE, standard error; $\mathrm{OC}$, oral contraceptive; ref, reference.

Model1: ANCOVA testing an interaction of CRF and BMI with $\log _{10}$ hs-CRP without adjustment for sex $\times$ OC

Model 2: ANCOVA testing an interaction of CRF and BMI with $\log _{10} \mathrm{hs}-\mathrm{CRP}$ after adjustment for sex $\times$ OC.

Note: hs-CRP was transformed into $\log _{10} \mathrm{hs}-\mathrm{CRP}(\mathrm{mg} / \mathrm{L})$; $\mathrm{CRF}$, continuous variable; BMI was divided into two categories (normal weight $<25$; overweight and obese $\geq 25$ ). 


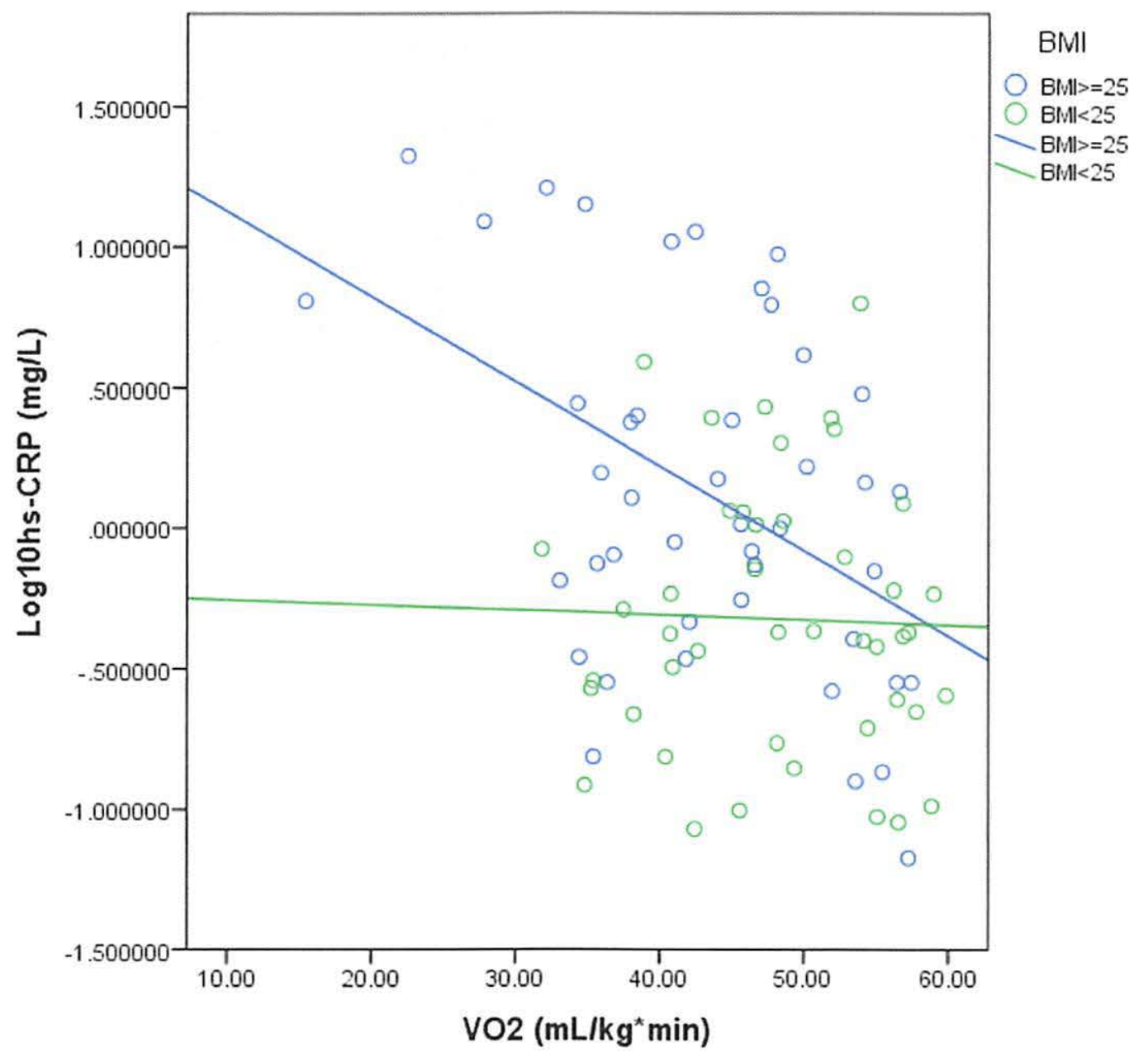

\begin{tabular}{|c|c|c|}
\hline & $\begin{array}{l}\text { Low Fitness } \\
(35 \mathrm{~mL} / \mathrm{kg} \cdot \mathrm{min})\end{array}$ & $\begin{array}{l}\text { High Fitness } \\
(55 \mathrm{~mL} / \mathrm{kg} \cdot \mathrm{min})\end{array}$ \\
\hline \multirow[t]{2}{*}{$\mathrm{BMI} \geq 25$} & $\log _{10} \mathrm{hs}-\mathrm{CRP}=0.379$ & $\log _{10} h s-C R P=-0.221$ \\
\hline & $\begin{array}{l}\mathrm{Hs}-\mathrm{CRP}=2.39 \\
\mathrm{mg} / \mathrm{L}\end{array}$ & $\begin{array}{l}\mathrm{Hs}-\mathrm{CRP}=0.60 \\
\mathrm{mg} / \mathrm{L}\end{array}$ \\
\hline \multirow[t]{2}{*}{$\mathrm{BMI}<25$} & $\begin{array}{l}\log _{10} h s-C R P=- \\
0.305\end{array}$ & $\begin{array}{l}\log _{10} \text { hs-CRP }=- \\
0.345\end{array}$ \\
\hline & $\begin{array}{l}\text { Hs-CRP = } 0.49 \\
\mathrm{mg} / \mathrm{L}\end{array}$ & $\begin{array}{l}\text { Hs-CRP = } 0.45 \\
\mathrm{mg} / \mathrm{L}\end{array}$ \\
\hline
\end{tabular}

Figure 2. Model1: ANCOVA testing an interaction of CRF and BMI with $\log _{10} \mathrm{hs}-\mathrm{CRP}$ without adjustment for confounders 
Table 6

Analysis of covariance for $\log _{10} h$ - $C R P$ as an interaction of $C R F$ and $W C(N=88)$

\begin{tabular}{|c|c|c|c|c|c|c|c|c|c|}
\hline Predictor variables & $R^{2}$ & $\operatorname{adj} R^{2}$ & $p$ & $B$ & $S E B$ & df & $\mathrm{F}$ & $p$ & $\begin{array}{l}\text { Partial } \\
\text { eta }^{2}\end{array}$ \\
\hline Model 1 & .338 & .314 & .000 & & & 3 & 14.283 & .000 & .338 \\
\hline Intercept & & & & .153 & .440 & 1 & 6.212 & .015 & .069 \\
\hline $\mathrm{CRF}(\mathrm{mL} / \mathrm{kg} \cdot \min )$ & & & & -.012 & .009 & 1 & 8.745 & .004 & .094 \\
\hline \multicolumn{10}{|l|}{$\mathrm{WC}(<86.4 \mathrm{~cm})(\mathrm{ref})$} \\
\hline WC $(\geq 86.4 \mathrm{~cm})$ & & & & 1.109 & .568 & 1 & 3.821 & .054 & .044 \\
\hline \multicolumn{4}{|c|}{$\mathrm{CRF}(\mathrm{mL} / \mathrm{kg} \cdot \mathrm{min}) \times \mathrm{WC}(\geq 86.4 \mathrm{~cm})$} & -.012 & .012 & 1 & 1.059 & .306 & .012 \\
\hline Model 2 & .446 & .412 & .000 & & & 5 & 13.207 & .000 & .446 \\
\hline Intercept & & & & .753 & .631 & 1 & 7.490 & .008 & .084 \\
\hline $\mathrm{CRF}(\mathrm{mL} / \mathrm{kg} \cdot \mathrm{min})$ & & & & -.023 & .012 & 1 & 7.456 & .008 & .083 \\
\hline \multicolumn{10}{|l|}{ WC $(<86.4 \mathrm{~cm})(\mathrm{ref})$} \\
\hline $\mathrm{WC}(\geq 86.4 \mathrm{~cm})$ & & & & .626 & .552 & 1 & 1.287 & .260 & .015 \\
\hline $\mathrm{CRF}(\mathrm{mL} / \mathrm{kg} \cdot \mathrm{min}) \times \mathrm{W}$ & $(\geq 86.4 c$ & & & -.003 & .012 & 1 & .079 & .779 & .001 \\
\hline & & & & & & 2 & 8.015 & .001 & .164 \\
\hline \multicolumn{10}{|l|}{ Male (ref) } \\
\hline Female (non-OC) & & & & -.244 & .173 & & & & \\
\hline Female $(O C)$ & & & & .406 & .178 & & & & \\
\hline
\end{tabular}

Abbreviations: CRF, cardiorespiratory fitness; WC, waist circumference; hs-CRP, high sensitive C-reactive protein; adj, adjusted; B, unstandardized coefficients; SE, standard error; OC, oral contraceptive; ref, reference.

Modell: ANCOVA testing an interaction of CRF and WC with $\log _{10}$ hs-CRP without adjustment for sex $\times$ OC

Model 2: ANCOVA testing an interaction of CRF and WC with $\log _{10}$ hs-CRP after adjustment for sex $\times$ OC.

Note: hs-CRP (mg/L) was transformed into $\log _{10} \mathrm{hs}-\mathrm{CRP}(\mathrm{mg} / \mathrm{L}) ; \mathrm{CRF}$, continuous variable; WC was divided into two categories based on the $50^{\text {th }}$ percentile (median value $=86.4 \mathrm{~cm}$ ). 
Table 7

Analysis of covariance for $\log _{10} I L-6$ as an interaction of $C R F$ and $B M I(N=87)$

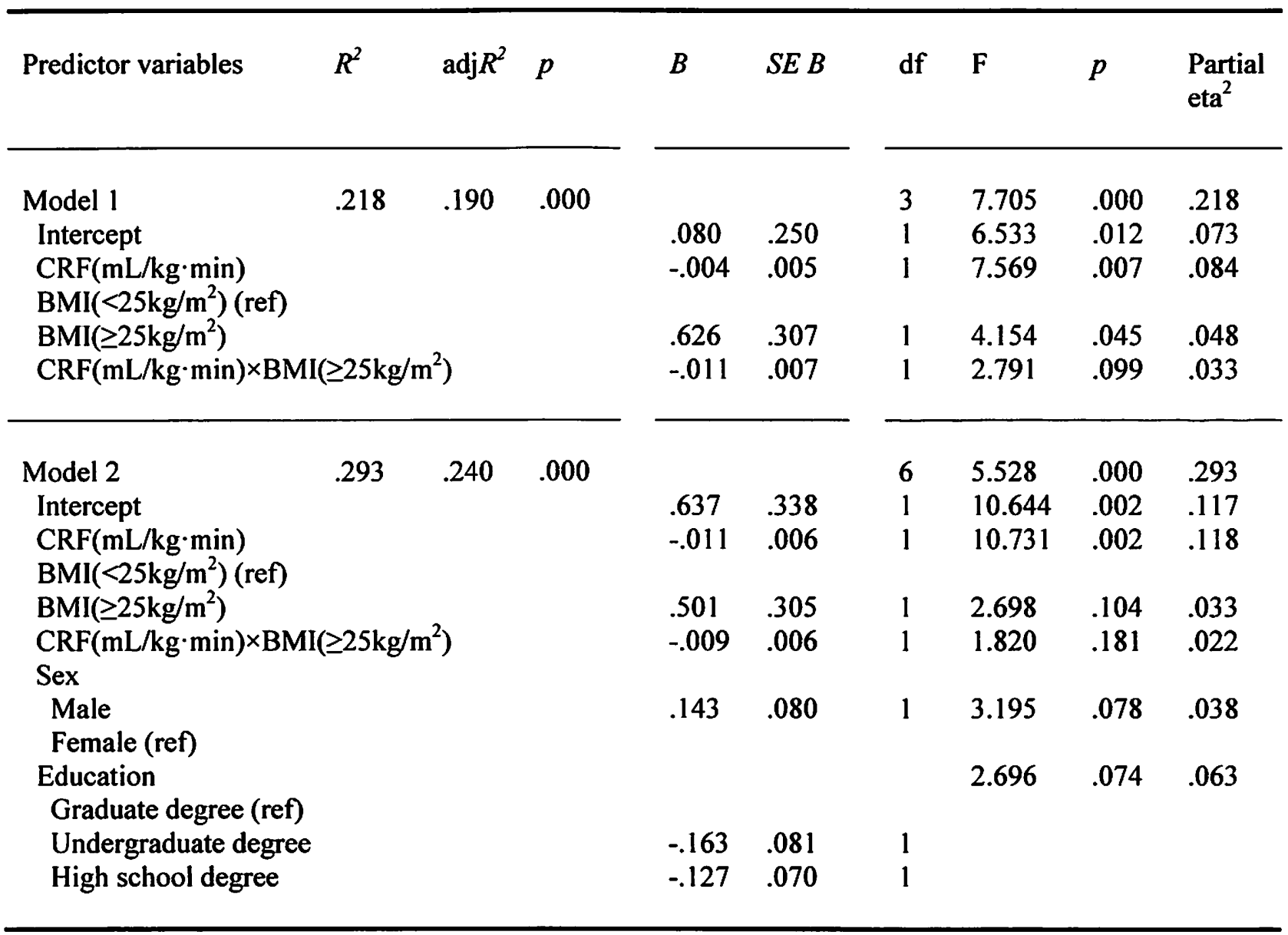

Abbreviations: CRF, cardiorespiratory fitness; BMI, body mass index; IL-6, interleukin-6; adj, adjusted; B, unstandardized coefficients; SE, standard error; ref, reference.

Model1: ANCOVA testing an interaction of CRF and BMI with $\log _{10}$ IL- 6 without adjustment for sex and education

Model 2: ANCOVA testing an interaction of CRF and BMI with $\log _{10} \mathrm{IL}-6$ after adjustment for sex and education.

Note: IL-6 (pg/mL) was transformed into $\log _{10} \mathrm{IL}-6(\mathrm{pg} / \mathrm{mL})$; CRF, continuous variable; BMI was divided into two categories (normal weight $<25 \mathrm{~kg} / \mathrm{m}^{2}$; overweight and obese $\geq 25 \mathrm{~kg} / \mathrm{m}^{2}$ ). 
Table 8

Analysis of covariance for $\log _{10} I L-6$ as an interaction of CRF and $W C(N=87)$

\begin{tabular}{|c|c|c|c|c|c|c|c|c|c|}
\hline Predictor variables & $R^{2}$ & $\operatorname{adj} R^{2}$ & $p$ & $B$ & $S E B$ & df & $\mathbf{F}$ & $p$ & $\begin{array}{l}\text { Partial } \\
\text { eta }^{2}\end{array}$ \\
\hline Model 1 & .255 & .228 & .000 & & & 3 & 9.456 & .000 & .255 \\
\hline Intercept & & & & -.017 & .224 & 1 & 8.596 & .004 & .094 \\
\hline $\mathrm{CRF}(\mathrm{mL} / \mathrm{kg} \cdot \mathrm{min})$ & & & & -.001 & .005 & 1 & 9.823 & .002 & .106 \\
\hline \multicolumn{10}{|c|}{$\mathrm{WC}(<86.4 \mathrm{~cm})(\mathrm{ref})$} \\
\hline $\mathrm{WC}(\geq 86.4 \mathrm{~cm})$ & & & & .876 & .287 & 1 & 9.306 & .003 & .101 \\
\hline \multicolumn{4}{|c|}{$\mathrm{CRF}(\mathrm{mL} / \mathrm{kg} \cdot \mathrm{min}) \times \mathrm{WC}(\geq 86.4 \mathrm{~cm})$} & -.016 & .006 & 1 & 7.254 & .009 & .080 \\
\hline Model 2 & .310 & .258 & .000 & & & 6 & 5.991 & .000 & .310 \\
\hline Intercept & & & & .511 & .332 & 1 & 10.763 & .002 & .119 \\
\hline $\mathrm{CRF}(\mathrm{mL} / \mathrm{kg} \cdot \mathrm{min})$ & & & & -.009 & .006 & 1 & 10.918 & .001 & .120 \\
\hline \multicolumn{10}{|c|}{ WC $(<86.4 \mathrm{~cm})(\mathrm{ref})$} \\
\hline$W C(\geq 86.4 \mathrm{~cm})$ & & & & .705 & .292 & 1 & 5.818 & .018 & .068 \\
\hline $\mathrm{CRF}(\mathrm{mL} / \mathrm{kg} \cdot \mathrm{min})$ & $(\geq 86.4$ & & & -.013 & .006 & 1 & 4.730 & .033 & .056 \\
\hline \multicolumn{10}{|c|}{ Sex } \\
\hline Male & & & & .128 & .083 & 1 & 2.386 & .126 & .029 \\
\hline \multicolumn{10}{|l|}{ Female (ref) } \\
\hline Education & & & & & & & 2.039 & .137 & .048 \\
\hline \multicolumn{10}{|c|}{ Graduate degree (ref) } \\
\hline Undergraduate $d$ & & & & -.141 & .070 & 1 & & & \\
\hline High school deg & & & & -.116 & .080 & 1 & & & \\
\hline
\end{tabular}

Abbreviations: CRF, cardiorespiratory fitness; WC, waist circumference; IL-6, interleukin-6; adj, adjusted; B, unstandardized coefficients; SE, standard error; ref, reference.

Model 1: ANCOVA testing an interaction of CRF and WC with $\log _{10} \mathrm{IL}-6$ without adjustment for sex and education

Model 2: ANCOVA testing an interaction of CRF and WC with $\log _{10} \mathrm{IL}-6$ after adjustment for sex and education.

Note: IL-6 (pg/mL) was transformed into $\log _{10} \mathrm{IL}-6(\mathrm{pg} / \mathrm{mL})$; CRF, continuous variable; WC was divided into two categories based on the $50^{\mathrm{th}}$ percentile (median value $=86.4 \mathrm{~cm}$ ). 


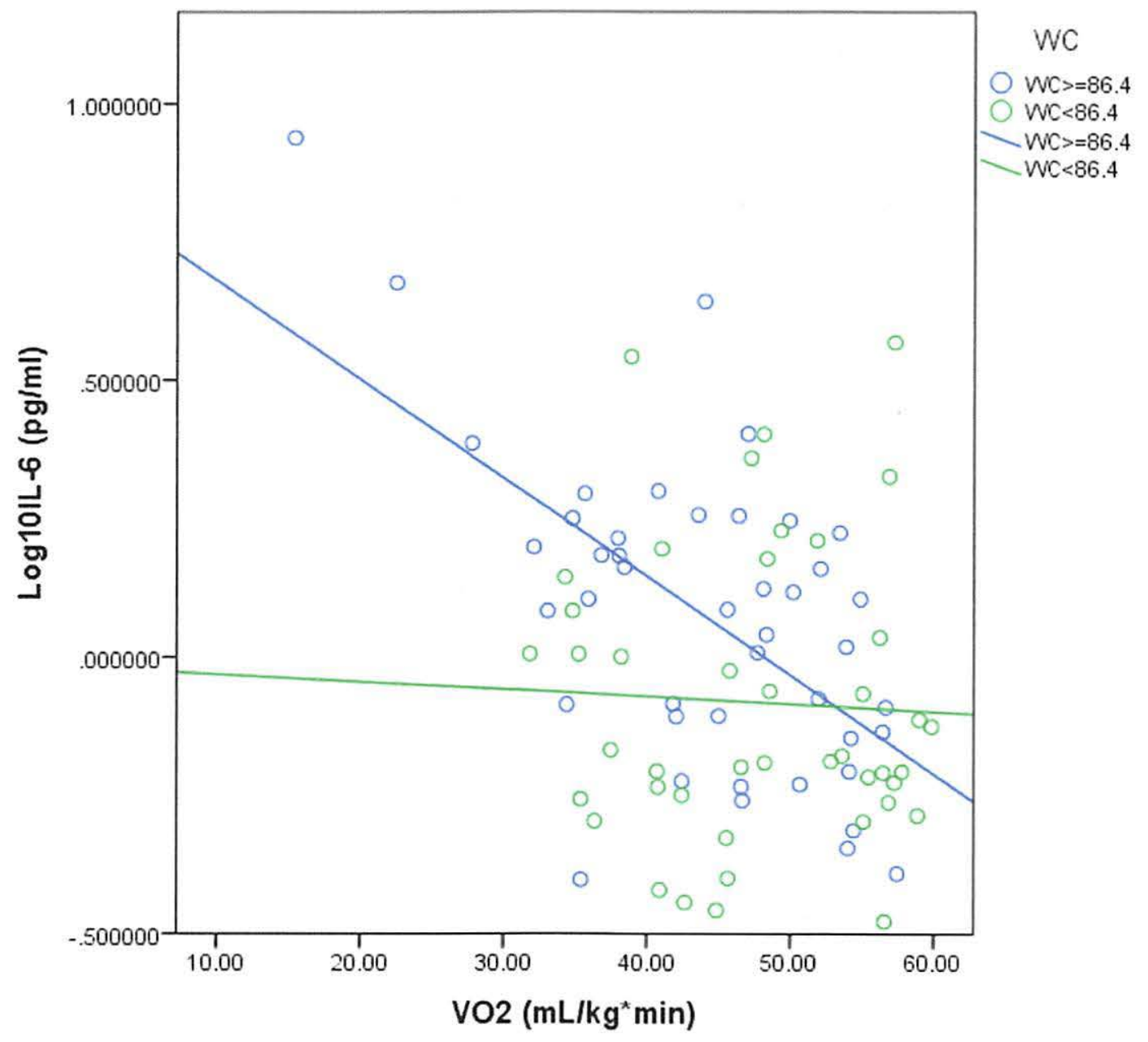

\begin{tabular}{|l|l|l|}
\hline & $\begin{array}{l}\text { Low Fitness } \\
(35 \mathrm{~mL} / \mathrm{kg} \cdot \mathrm{min})\end{array}$ & $\begin{array}{l}\text { High Fitness } \\
(55 \mathrm{~mL} / \mathrm{kg} \cdot \mathrm{min})\end{array}$ \\
\hline \multirow{2}{*}{$\begin{array}{l}\mathrm{WC} \geq 86.4 \\
\mathrm{~cm}\end{array}$} & $\log _{10} \mathrm{IL}-6=0.264$ & $\log _{10} \mathrm{IL}-6=-0.076$ \\
\cline { 2 - 3 } & IL-6 $=\mathbf{1 . 8 3} \mathbf{~ p g} / \mathbf{m l}$ & IL-6 $=\mathbf{0 . 8 3} \mathbf{~ p g} / \mathbf{m l}$ \\
\hline $\begin{array}{l}\mathrm{WC}<86.4 \\
\mathrm{~cm}\end{array}$ & $\log _{10} \mathrm{IL}-6=-0.052$ & $\log _{10} \mathrm{IL}-6=-0.072$ \\
\cline { 2 - 3 } & IL-6 $=\mathbf{0 . 8 8} \mathbf{~ p g} / \mathbf{m l}$ & IL-6 $=\mathbf{0 . 8 4} \mathbf{~ p g} / \mathbf{m l}$ \\
\hline
\end{tabular}

Figure 3. Model1: ANCOVA testing an interaction of cardiorespiratory fitness and WC with $\log _{10} \mathrm{IL}-6$ 
Appendix A

Study Flyers 


\section{ATTENTION!!}

Individuals between the ages of 20 and 34 are needed to participate in a new research study!!

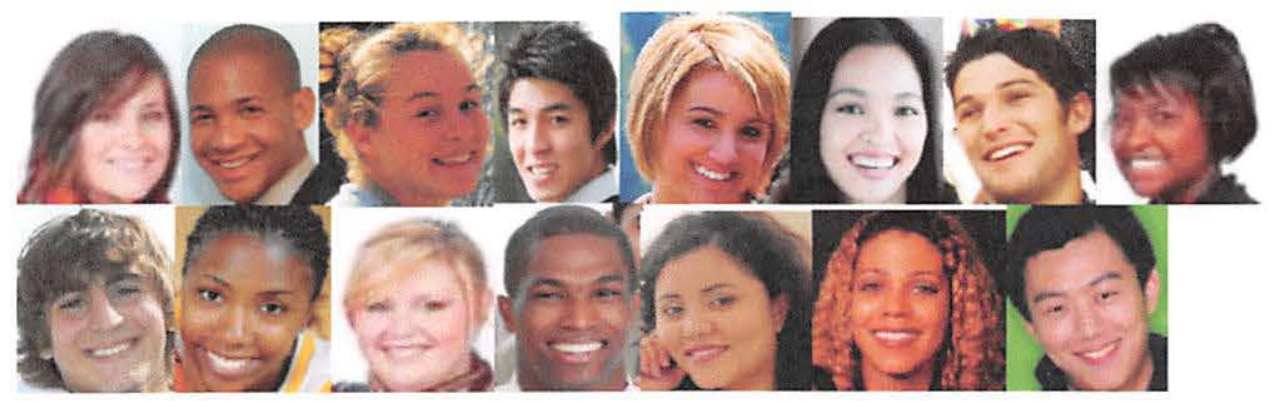

We are seeking individuals without heart disease, respiratory conditions and chronic disease for a study of young adults.

During one visit to the research center participants in this study will:

- Treadmill walk test to monitor heart rate

- Have a blood test

- Answer some basic questions about yourself.

- Be compensated for your participation in this study.

If you are interested or have further questions please call 716-909-4121 or email: Eunduck.Park@uth.tmc.edu Eunduck Park, MSN, ANP, RN

University of Texas Health Science Center, School of Nursing

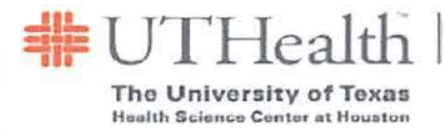

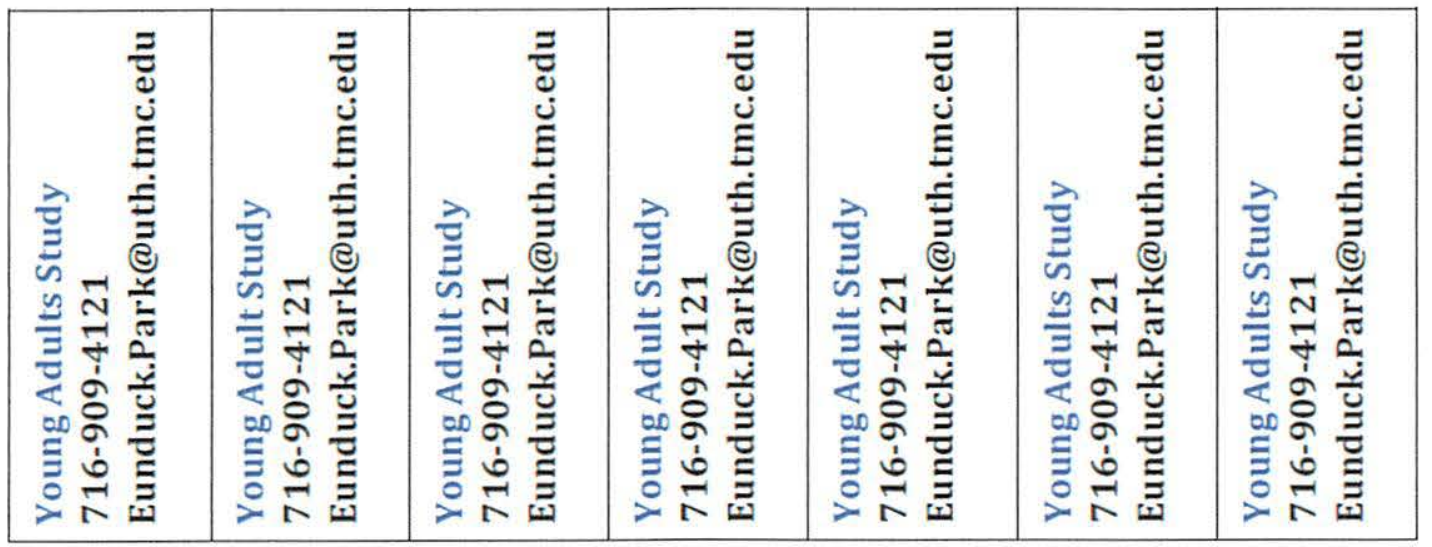

IRB NUMBER: HSC-SN-12-0323 


\section{ATTENTION!!}

Individuals between the ages of 20 and 34 are needed to participate in a new research study!!
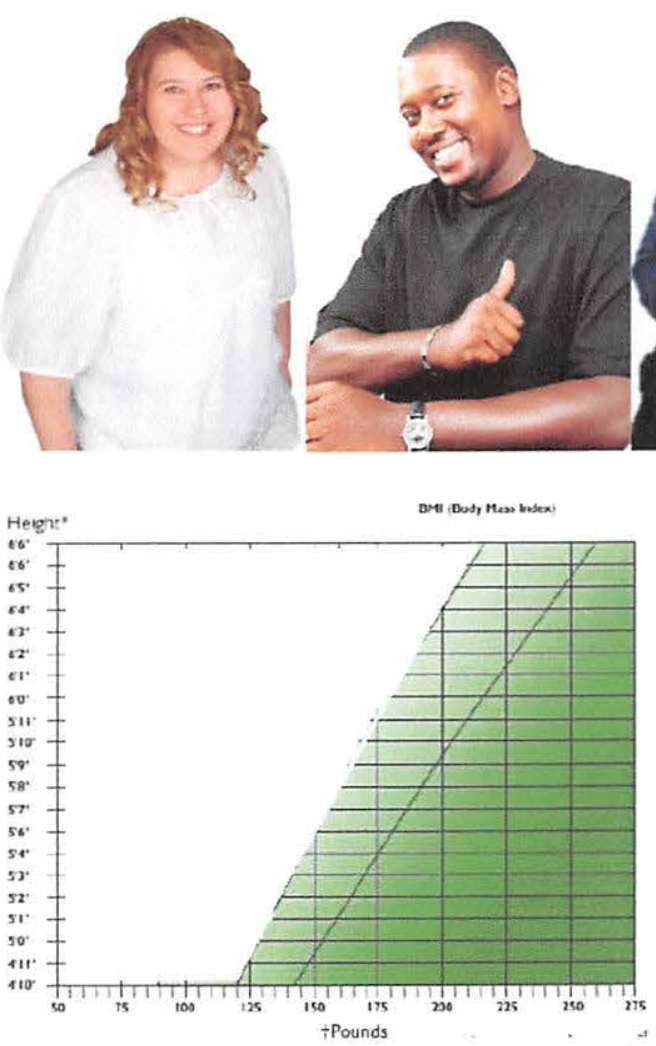

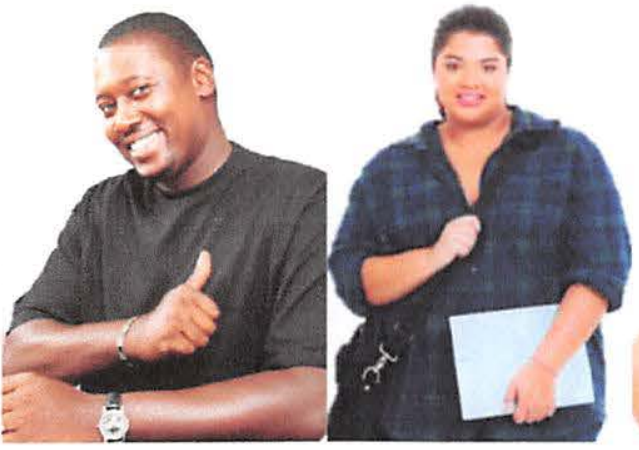

We are seeking young males and females who are in the green color (Body Mass Index (BMI) > 25) without smoking, heart disease, respiratory conditions and other chronic diseases.

During one visit to the research center. participants in this study will:

- Have treadmill walk test.

- Have a blood test.

- Answer some basic questions about yourself.

- Be compensated for your participation.

If you are interested or have further questions please call email:

Eunduck.Park@uth.tmc.edu or call 716-909-4121

Eunduck Park, MSN, RN, ANP, The University of Texas School of 非 UTHealth | Nursing

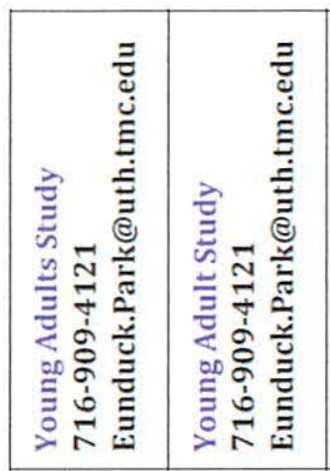

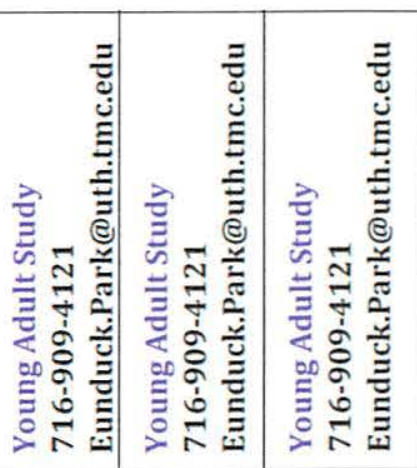
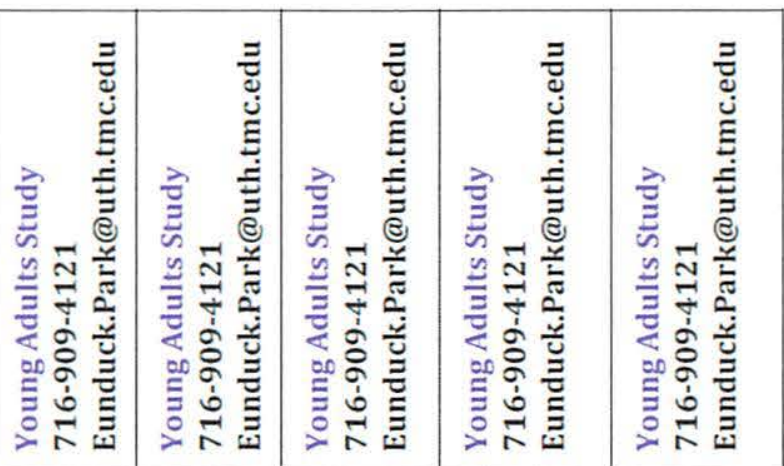

IRB NUMBER: HSC-SN-12-0323

UTHealth IRB APPROVAL DATE: 10/03/2013 
Appendix B

Eligibility Criteria Check List 


\section{Participants' Initial Eligibility Checklist}

Identification

\begin{tabular}{|ll|l|}
\hline 1. Interviewers name & 2. Date $(\mathrm{mm} / \mathrm{dd} / \mathrm{yy})$ \\
\hline 3. Participant Initials: $\overline{\text { First }} \quad \overline{\text { Last }}$ & \\
\hline
\end{tabular}

\section{Inclusion Criteria}

(A check "No" in any of following questions (Q4-Q8) indicates that the potential participant is not eligible for the study)

If the participant "Don't know", check "I" on NO.

\begin{tabular}{|l|l|l|}
\hline & Yes & No \\
\hline 4. Young adults aged 20-34 & & \\
\hline 5. Is capable of cardiorespiratory fitness test (Treadmill walk test)? & & \\
\hline 6. Is able to speak. read. comprehend and respond in English? & \\
\hline For Womten only & & \\
\hline $\begin{array}{l}\text { 7. Menstrual cycle length of 24-35 days during the last 2 months } \\
\text { (If a participant is on a period now. she will be scheduled a day when } \\
\text { she is not on her menstruating period). }\end{array}$ & & \\
\hline $\begin{array}{l}\text { 8. Are you having your period now? } \\
\text { P. }\end{array}$ & & \\
\hline
\end{tabular}




\section{Exclusion Criteria}

(A check "yes" in any of flowing questions (Q9-Q27) indicates that the potential participant is not eligible for the study)

If the participant "Don't know", check "I" on NO.

\begin{tabular}{|c|c|c|}
\hline & Yes & No \\
\hline 9. Acute smoking. current smokers or smoking cessation less than 1 year & & \\
\hline $\begin{array}{l}\text { 10. Alcohol dependence or regular alcohol consumption }>7 \text { servings } \\
\text { per week }\end{array}$ & & \\
\hline $\begin{array}{l}\text { 11. Acute infection. a current or recent influenza illness or a } \\
\text { recent flu shot recipient. acute respiratory infection within 2weeks }\end{array}$ & & \\
\hline 12. Dental infection or problem within 2 weeks & & \\
\hline $\begin{array}{l}\text { 13. Chronic diseases: cardiovascular diseases: hypertension. lipidemia. } \\
\text { and type } 2 \text { diabetes }\end{array}$ & & \\
\hline 14. Inmume disorders: rheumatoid arthritis & & \\
\hline $\begin{array}{l}\text { 15. History of osteoporotic injury and limitations due to the } \\
\text { musculoskeletal demands of cardiorespiratory fitness test. or other bone } \\
\text { diseases }\end{array}$ & & \\
\hline 16. History of osteoporosis & & \\
\hline 17. Recent surgery within 1 month & & \\
\hline $\begin{array}{l}\text { 18. Currently taking medications: hormone replacement therapy. anti- } \\
\text { hypertensive medications. anti-platelet or coagulation medications. } \\
\text { allergy shots or systemic corticosteroids, or selective serotonin uptake } \\
\text { inhibitors }\end{array}$ & & \\
\hline $\begin{array}{l}\text { 19. Anti-inflammatory medications: statin. aspirin or had taken these } \\
\text { medications in the past } 48 \text { hours }\end{array}$ & & \\
\hline $\begin{array}{l}\text { 20. Other medical conditions or medications that would prohibit } \\
\text { participation in exercise and blood sampling } \\
\text { (If yes. please list below) }\end{array}$ & & \\
\hline
\end{tabular}




\begin{tabular}{|l|l|l|}
\hline For women only, & Yes & No \\
\hline 21. Menopausal status & & \\
\hline 22. Use of hormone replace therapy & & \\
\hline 23. Is currently preguant & & \\
\hline 24. Lactating female & & \\
\hline $\begin{array}{l}\text { 25. History of gynecologic problems. such as endometriosis or } \\
\text { polycystic ovary syudrome }\end{array}$ & & \\
\hline $\begin{array}{l}\text { 26. Hormonal contraception use except oral contraception: patch. depo- } \\
\text { provera }\end{array}$ & & \\
\hline $\begin{array}{l}\text { 27. Intra Uterine Devices with hormones and Depo-Provera within past } \\
\text { 12 months }\end{array}$ & & \\
\hline
\end{tabular}

Participant's Eligibility: Yes No 
Appendix C

\section{Informed Consent}




\title{
THE UNIVERSITY OF TEXAS HEALTH SCIENCE CENTER - HOUSTON
}

\author{
Association of Cardiorespiratory Fitness and Adiposity with Inflammatory Biomarkers in \\ Healthy Young Adults
}

HSC-S.N-12-0323

\section{INFORMED CONSENT TO JOIN A RESEARCH STUDY}

\section{INVITATION TOTAKF PART}

You are invited to take pant in a research project called. "Association of Cardiorespiratory Fitness and Adiposity with Lnflammatory Biomarkers in Healthy Young Adults." conducted by Eunduck Park. MSN. ANP. RN of the University of Texas Health Science Center. For this research project. she will be called the Principal Investigator or PI.

You have been invited to join this research study because healthy young adult volunteers are needed to conduct this research project. Your decision to take part is voluntary and you may refise to take part. or choose to stop from taking part. at any time. A decision not to take part or to stop being a part of the research project will not change the services available to you from the medical community. You may refuse to answer any questions asked or written on any fonus.

This research project has been reviewed by the Committee for the Protection of Human Subjects (CPHS) of the Unversity of Texas Health Science Center at Houston as HSC-SN-120323.

\section{DESCRIPTION OF RESEARCH:}

PIRPOSE. The purpose of this research study is to look at firstly how your physical fitness (based on a treadmill walk test) is associated with inflammatory markers in you body. Secondly, how body weight is associated with inflammatory markers in your body. Lastly, how you fituess and weight ate associated with inflammatory makers in you body. 
Scientists have debated whether fitness is more associated with inflammatory markers or if body weight is more associated with inflammatory markers in your body. High levels of inflammation have been shown to be related to heart disease. The findings of this study may help to improve health care and to design programs to maintain and improve the health of young adults. However, the tests performed in this study are not diagnostic and will not predict if you will get heart disease

This is a local study that will enroll a total of 88 subjects in Houston.

\section{PROCEDIRE:}

If you agree and are able to take part in this study, you will undergo the following procedures after signing this infomed consent:

- You will be asked to fill out a pre-assessment health questionnaire to identify if it is safe for you to take the fitness test. If it is not safe to test your fitness, you will be excluded from this study. The demographic questionnaire includes age, gender. ethnicity, martial status, and education. You will also be interviewed about your health conditions.

- If you are eligible to participate in this study. you will be scheduled for blood testing. body measurements, such as height and weight, and physical fitness test. This test will be performed one day at the UTHSC-H, School of Nursing and taken about 3 hours

- For your scheduled test day, you are asked not to eat after 8 pm the night before the test. Additionally, you are asked not to do strenuous exercise or physical activity, drink alcohol, or use anti-inflammatory drugs 24 hours prior to the blood draw. You are asked to arrive at the laboratory at the School of Nursing between 8 am and $10 \mathrm{am}$ for blood test. We will draw $10 \mathrm{ml}$ (about 2 teaspoons) of blood for inflammation testing. For the fitness test, you are asked to wear comfortable exercise-type clothing, and avoid tobacco and caffeine 3 hours prior to test. You are also asked to have an adequate amount sleep the night before the test.

- After blood test, study professional staff will measure your height. weight and waist circumference. These measures are to assess your body size. You will be asked to remove any outer clothing, such as a sweater, as well as hat and shoes.

- After these measurements, you will be given a light free lunch with juice or water

- After having a light lunch and brief resting period, the investigator will test your fitness. This test assesses how your body handles physical activity. This test will take 20-30 minutes of walking on the treadmill with warm-up and cool down stages. You will be asked to wear a heart rate monitor around your chest. Study staff will guide you during the test. 
Appendix D

Pre-Assessment Health Questionnaire 


\section{Pre-assessment Health Questionnaire}

Pre-assessment Health Questionnaire consists of two sections; section 1. demographic information and section 2. pre-assessment questionnaires. Section 1 demographic information includes information on age, gender, ethnicity, marital status, and education. Section 2 preassessment health questionnaire will be used to determine the individual's risk related to cardiorespiratory fitness participation. The questionnaire is designed to identify whether the participants are appropriate and safe to test for cardiorespiratory fitness.

The objectives of the pre-assessment health questionnaire are:

- To identify those with a medical contraindication.

- To identify those with other health risk/medical concerns that may influence the decision about performing a cardiorespiratory fitness test (sub-maximal treadmill test). 


\section{Pre-Health Assessment Questionnaire}

Intervieiver's name:

Study unit identifier:

1

Date of Interview:

$L_{\text {(Month) }}^{\mid} / L_{\text {(Date) }} \mid /$

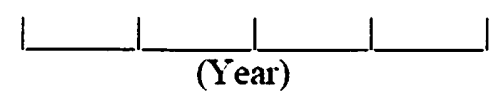

\begin{tabular}{|c|c|}
\hline $\begin{array}{l}\text { Question } \\
\#\end{array}$ & Item \\
\hline \multicolumn{2}{|c|}{ Section 1: Demographic Information (Q1-Q6) } \\
\hline 1 & $\begin{array}{l}\text { Respondent's gender: } \\
\text { MALE [ } 1 \text { ] _ FEMLALE [ } 2 \text { ] }\end{array}$ \\
\hline 2 & $\begin{array}{l}\text { "How old did you turn on your last birthday?" } \\
\text { _ years old }\end{array}$ \\
\hline
\end{tabular}




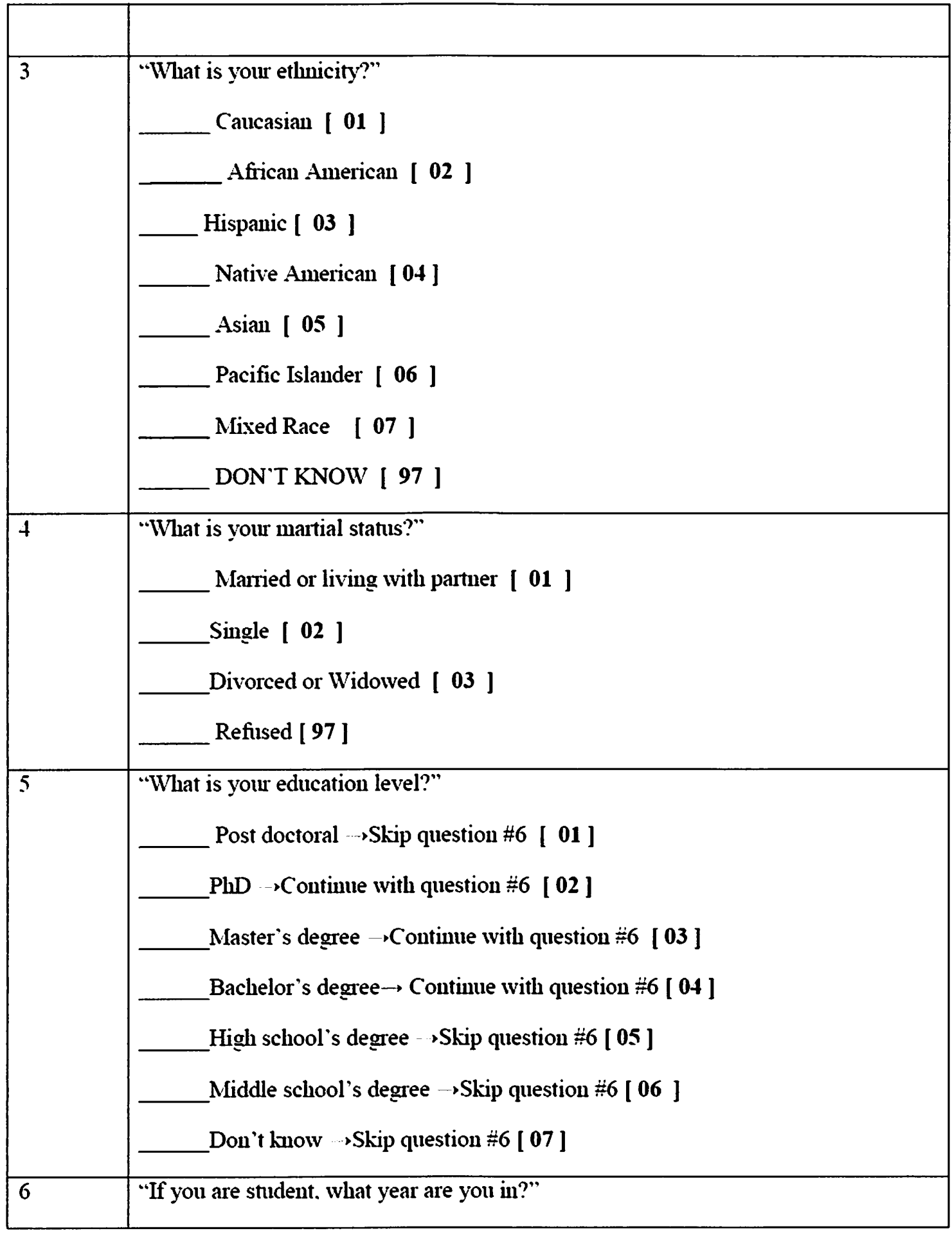




\section{Section 2: Pre-Assessment Questionnaires}

Reference: American College of Sports Medicine (b). ACSM's health-related physical fitmess assessment manual. 3rd ed. Philadelphia (PA): Lippincott. Williams \& Wilkins: 2010 (p.20-21

Please provide responses (YES or NO) to the following concerning family history, your own history, and any symptoms you have had:

\begin{tabular}{|lcc|}
\hline \multicolumn{4}{|c|}{ FAMILY HISTORY } \\
Have any Immed are ramily memhers \\
had a: & YES & NO \\
& 0 & $c$ \\
heart attack & 0 & 0 \\
heart surgery & 0 & 0 \\
coronary sient & 0 & 0 \\
Cardiac catheterization & 0 & 0 \\
congenital heat defect & 0 & 0 \\
stroke & 0 \\
Osher chronic cisease: & \\
\hline
\end{tabular}

\begin{tabular}{|lcc|}
\hline \multicolumn{3}{|c|}{ PERSONAL HISTORY } \\
Have you ever had: & VES NO \\
High blood pressure & 0 & 0 \\
Higlh cholesterol & 0 & 0 \\
Diabetes & 0 & 0 \\
Any heart problems & 0 & 0 \\
Discase of arteries & 0 & 0 \\
Ihyroic cisease & 0 & 0 \\
Lung discasc & 0 & 0 \\
Asthma & 0 & 0 \\
Canscr & 0 & 0 \\
Kidrey disease & 0 & 0 \\
Hepatitis & 0 & 0 \\
Other: & \\
\hline
\end{tabular}

\begin{tabular}{|lcc|}
\hline \multicolumn{3}{|c|}{ SYMPTOMS } \\
Have you ever had: & VES NO \\
Chest pain & 0 & 0 \\
Shorness of breath & 0 & 0 \\
Heart palpitaticns & 0 & 0 \\
Skifped heartbeats & 0 & 0 \\
Heart murmur & 0 & 0 \\
Intermitcent leg pain & 0 & 0 \\
Dieziness or fainting & 0 & 0 \\
Fatigue - usual activities & 0 & 0 \\
Snoring & 0 & 0 \\
Back pain & 0 & 0 \\
Orthofedic problems & 0 & 0 \\
Orher: & \\
\hline
\end{tabular}

STAFF COMNENTS:

Have you ever had your cholesterol measured? Yes $\square$ No $\square$ If yes, value Where:

Are you taking any prescription (include birth control pills) or nonprescription medications? $\quad$ Yes $\square \quad$ No $\square$ For each of your current medications, provide the following information:

MEDICATION Dosage-times/day Time taken Years on medication Reason for taking 
HOSPITALIZATIONS: Please list recent hospitalizations (Women: do not list normal pregnancies)

Year

Location

Reason

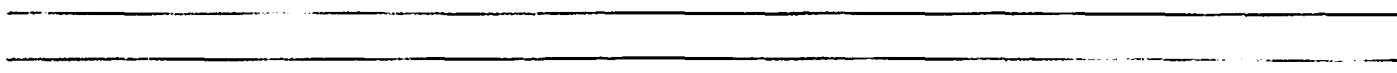

Any orher medical problems/concerns not already identified? Yes $\square$ No $\square$ if so, please list:

\section{LIFESTYLE HABITS}

Du you ever have an uncomfortable shortness of breath during exercise or when doing activities? Yes $\square$ No $\square$

Do you ever have chest discomfort during exercise? Yes [] NoL If so, does it go away with rest? Yes $\square$ No $\square$

Do you currently smoke? Yes $\square$ No $\square$ If so, what? Cigarettes $\square$ Cigars $\square$ Pipe $\square$

How long have you smoked? ___ years

How much per day: <1/2 pack $\square \quad 1 / 2$ to 1 pack $\square \quad 1$ to $1 \frac{1}{2}$ packs $\square \quad 1 / 2$ to 2 packs $\square>2$ packs $\square$

Have you ever quit smoking? Yes $\square$ No $\square$ When?

How many years and how much did you smoke?

Do you drink any alcoholic beverages? Yes.7 No $\square$ If yes, how much in 1 week? (indicate below) Beer __ (cans) Wine___ (glasses) Hard liquor___ (drinks)

Do you drink any caffeinated beverages? Yes $\square$ No $\square$ If yes, how much in 1 week? (indicate below) Coffec (cups)

Tea (glasses) Soft drinks (cans)

Are you currently following a weight reduction diet plan? Yes $\square$ No $\square$

If so, how long have you been dieting? monchs

is the plan prescribed by your doctor? Yes $\square$ No $\square$

Have you used weight reduction diets in the past? Yes $\square$ No $\square$ If yes, how often and what type?

ACTIVITY LEVEL EVALUALUN

What is your occupational activity level? Sedentary [: Lighrl] Moderate $\square$ Heavy $\square$ Do you currently engage in vigorous physical activity on a regular basis? Yes $\square$ No $\square$

If so, what type(s)? How many days per week?

How much time per day? $\quad<15 \min \square \quad 15-30 \min \square \quad 31-60 \min \square>60 \min \square$ How long have you engaged in this type of activity? $\quad<3$ mumhs $\square \quad 3-12$ months $\square>1$ year $\square$

Do you engage in any recreational or leisure-time physical activities on a regular basis? Yes $\square$ No $\square$ If so, what activities? On average: How often? times/week; for how long? time/session

How long have you engaged in this type of activity? $<3$ monchs 3-i2 months $>1$ year 
Appendix E

Flow Chart for Sampling and Data Collection 


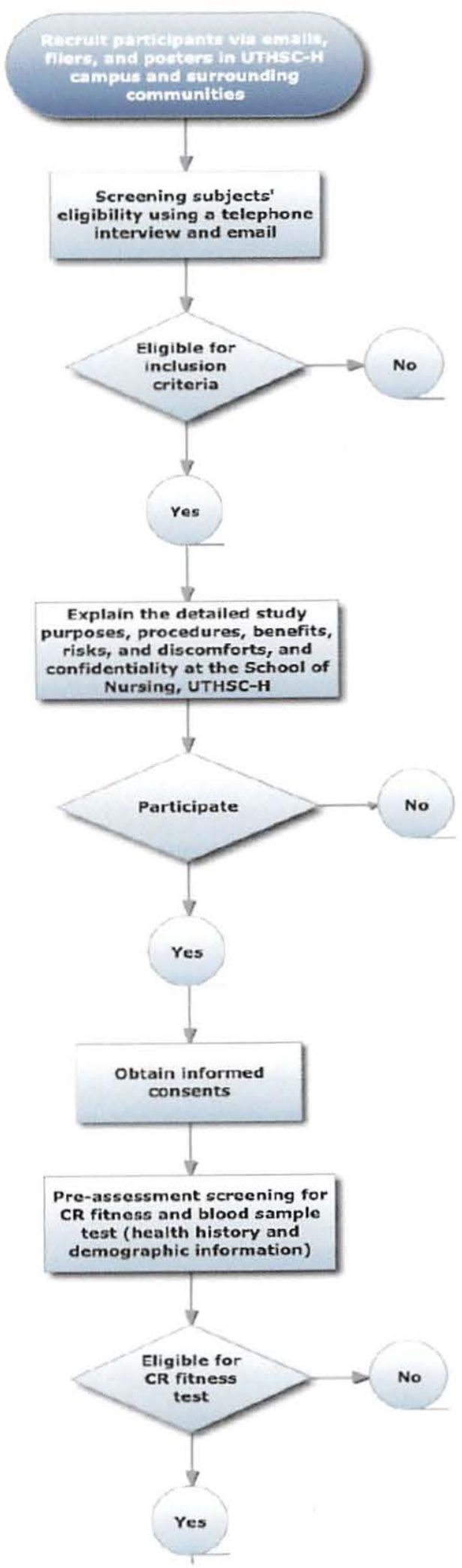




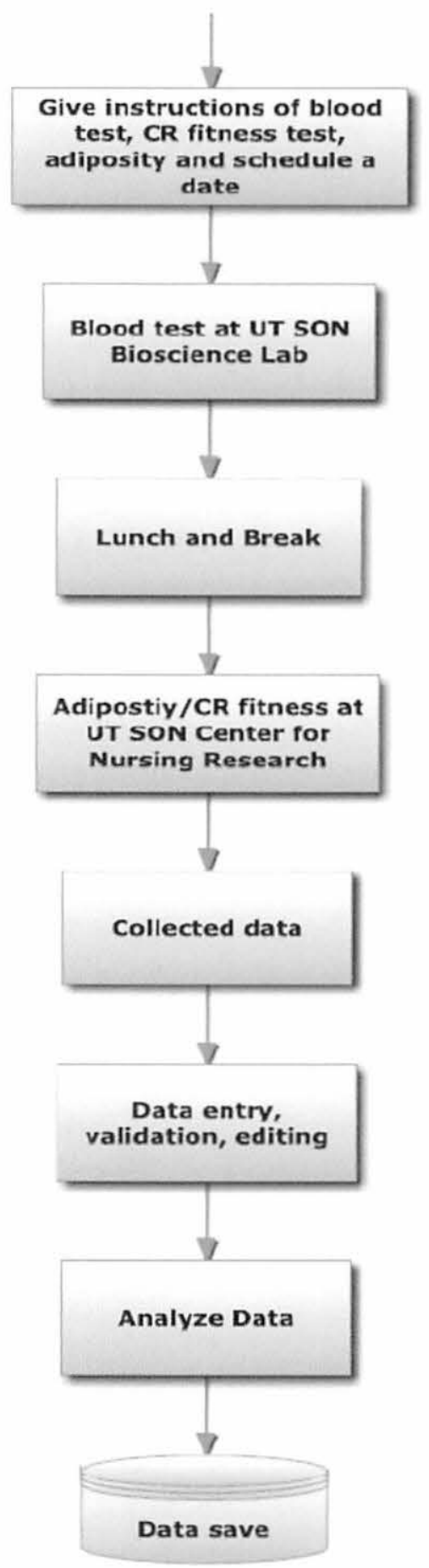




\section{Appendix $\mathbf{F}$}

Time Frame for Project 2012-2013 
Time Frame for Project 2012-2013

\begin{tabular}{|l|c|l|l|l|l|l|l|l|l|l|l|l|l|l|}
\hline & $\begin{array}{l}\text { Jun } \\
2012\end{array}$ & Aug & Sep & Oct & Nov & Dec & Jan & Feb & Mar & Apr & May & Jun & July & Aug \\
\hline $\begin{array}{l}\text { Human subjects } \\
\text { approvial }\end{array}$ & $\mathrm{X}$ & & & & & & & & & & & & & \\
\hline $\begin{array}{l}\text { Setting study room } \\
\text { and equipment }\end{array}$ & & $\mathrm{X}$ & $\mathrm{X}$ & $\mathrm{X}$ & $\mathrm{X}$ & & & & & & & & & \\
\hline $\begin{array}{l}\text { Recruit } \\
\text { participants }\end{array}$ & & & & & $\mathrm{X}$ & $\mathrm{X}$ & $\mathrm{X}$ & $\mathrm{X}$ & $\mathrm{X}$ & $\mathrm{X}$ & $\mathrm{X}$ & $\mathrm{X}$ & $\mathrm{X}$ & $\mathrm{X}$ \\
\hline $\begin{array}{l}\text { Data } \\
\text { Collection }\end{array}$ & & & & & $\mathrm{X}$ & $\mathrm{X}$ & $\mathrm{X}$ & $\mathrm{X}$ & $\mathrm{X}$ & $\mathrm{X}$ & $\mathrm{X}$ & $\mathrm{X}$ & $\mathrm{X}$ & $\mathrm{X}$ \\
\hline Data Entry & & & & & & & & & $\mathrm{X}$ & $\mathrm{X}$ & $\mathrm{X}$ & $\mathrm{X}$ & $\mathrm{X}$ & $\mathrm{X}$ \\
\hline Analyze data & & & & & & & & & & & & & $\mathrm{X}$ & $\mathrm{X}$ \\
\hline
\end{tabular}


Appendix G

\section{Notification Approval}


UTHealth

The University of Texas

Health Science Center at Houston
Committee for the Protection of Human Subjects

\section{NOTICE OF APPROVAL TO IMPLEMENT REQUESTED CHANGES}

May 28, 2013

HSC-SN-12-0323 - Association of Cardiorespiratory Fitness and Adiposity with Inflammatory Biomarkers in Healthy Young Adults

PI: Eun Duck Park

Reference Number: 096182

PROVISIONS; Unless otherwise noted, this approval relates to the research to be conducted under the above referenced title and/or to any associated materials considered at this meeting, e.g. study documents, informed consent, etc.

APPROVED: $\quad$ By Expedited Review and Approval

CHANGE APPROVED: Posting CPHS approved flyers at Harris County Community College and University of Houston

REVIEW DATE: $\quad$ May 27, 2013

APPROVAL DATE: $\quad$ May 28, 2013

CHAIRPERSON: John C. Ribble, MD<smiles>CCCCCCCCCCCCC</smiles>

Upon receipt of this letter, and subject to any provisions noted above, you may now implement the changes approved.

CHANGES: The principal investigator (PI) must receive approval from the CPHS before initiating any changes, including those required by the sponsor, which would affect human subjects, e.g. changes in methods or procedures, numbers or kinds of human subjects, or revisions to the informed consent document or procedures. The addition of co-investigators must also receive approval from the CPHS. ALL PROTOCOL REVISIONS MUST BE SUBMITTED TO THE SPONSOR OF THE RESEARCH.

INFORMED CONSENT: Informed consent must be obtained by the PI or designee(s), using the format and procedures approved by the CPHS. The PI is responsible to instruct the designee in the methods approved by the CPHS for the consent process. The individual obtaining informed consent must also sign the consent document. Please note that if revisions to the informed consent form were made and approved, then old blank copies of the ICF MUST be destroved. Only copies of the appropriately dated. stamped approved informed consent form can be used when obtaining consent. 
UNANTICIPATED RISK OR HARM, OR ADVERSE DRUG REACTIONS: The PI will immediately inform the CPHS of any unanticipated problems involving risks to subjects or others, of any serious harm to subjects, and of any adverse drug reactions.

RECORDS: The PI will maintain adequate records, including signed consent documents if required, in a manner that ensures subject confidentiality. 


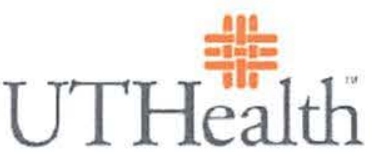

The University of Texas Health Science Center at Houston
Committec for the Protection of Human Subjects

NOTICE OF APPROVAL TO IMPLEMENT REQUESTED CHANGES

October 31, 2012

HSC-SN-12-0323 - Association of Cardiorespiratory Fitness and Adiposity with Inflammatory Biomarkers in Healthy Young Adults

PI: Dr. Eunduck Park

Reference Number: 088871

PROVISIONS: Unless otherwise noted, this approval relates to the research to be conducted under the above referenced title and/or to any associated materials considered at this meeting, e.g. study documents, informed consent, etc.

APPROVED: By Expedited Review and Approval

CHANGE APPROVED: Revised Protocol Version 1.4. (dated 9/29/2012)

And Consent Document Version 1.1 (dated 10/31/2012)

REVIEW DATE: $\quad$ October 30, 2012

APPROVAL DATE: October 31, 2012

CHAIRPERSON: Richard Kirkeeide, PhD

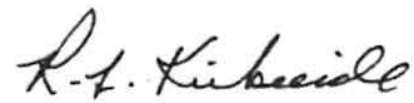

Upon receipt of this letter, and subject to any provisions noted above, you may now implement the changes approved.

CHANGES: The principal investigator (PI) must receive approval from the CPHS before initiating any changes, including those required by the sponsor, which would affect human subjects, e.g. changes in methods or procedures, numbers or kinds of human subjects, or revisions to the informed consent document or procedures. The addition of co-investigators must also receive approval from the CPHS. ALL PROTOCOL REVISIONS MUST BE SUBMITTED TO THE SPONSOR OF THE RESEARCH.

INFORMED CONSENT: Informed consent must be obtained by the PI or designee(s), using the format and procedures approved by the CPHS. The PI is responsible to instruct the designee in the methods approved by the CPHS for the consent process. The individual obtaining informed consent must also sign the consent document. Please note that if revisions to the informed consent form were made and approved, then old blank copies of the ICF MUST be destroyed. Only copies of the appropriately 
dated, stamped approved informed consent form can be used when obtaining consent.

UNANTICIPATED RISK OR HARM, OR ADVERSE DRUG REACTIONS: The PI will immediately inform the CPHS of any unanticipated problems involving risks to subjects or others, of any serious harm to subjects, and of any adverse drug reactions.

RECORDS: The PI will maintain adequate records, including signed consent documents if required, in a manner that ensures subject confidentiality. 


\section{Eunduck Park, MSN, RN}

\section{EDUCATION}

The University of Texas

2010-2014 PhD Nursing

Health Science Center

at Houston (UTHSC-H)

The State University of New York

at Buffalo

2008-2010

MS Nursing

Adult Nurse Practitioner

The State University of New York

at Buffalo

2005-2007

BS

Nursing

Suwon Women's College

1993-1996

$\mathrm{AD}$

Nursing

Suwon, South Korea

\section{LICENSURE \& CERTIFICATION}

State

Active or Inactive

Nurse Practitioner in Adult Health

New York State

Inactive

May 2010- May 2013

Registered Nurse

Active

Texas State

2010-Present

Registered Nurse

Active

New York State

2003-Present

Registered Nurse

Active

Republic of Korea

1996-Present

Basic Life Support for Health Care Provider, 2008-Present Collaborative IRB Training Initiative (CITI), 2009-Present HIPPA Certificate, 2009

Teacher's Certificate, School Nurse in Republic of Korea, 1996-Present 


\section{PROFESSIONAL EXPERIENCE}

Institution

Dates

ST. Mary's Hospital

CATHOLIC UNIVERSITY

Seoul, South Korea

Medical Unit

Buffalo General Hospital

Orthopedic Unit

Buffalo, New York

The University of Texas

Health Science Center at Houston

School of Nursing

\section{HONORS AND AWARDS}

Award

National Nursing Honor Society
Position Title

Registered Nurse

(Full time)

Registered Nurse

(Full time)

Teaching Assistant
Inclusive

May 1996-July 2001

August 2007-July 2008

May 2013-August 2014
Award Organization

Zeta Pi Chapter

The UTHSC-H

School of Nursing

The UTHSC-H

Full tuition support for

Three years of the $\mathrm{PhD}$ program

James T. and Nancy B. Willerson

Endowment Scholarship

Sigma Theta Tau International

Zeta Pi Chapter,

PhD Excellent Award
Sigma Theta Tau

International,

Gamma Kappa Chapter

The State of New York at Buffalo

School of Nursing

Date

March 2007

March 2011
School of Nursing

The UTHSC-H

School of Nursing

August 2013

The UTHSC-H

May 2014

August 2010-May 2013

School of Nursing 


\section{RESEARCH GRANTS}

Association of Cardiorespiratory Fitness and Adiposity with Inflammatory Biomarkers in Young Adults (Dissertation), Principal Investigator

Sigma Theta Tau International, Zeta Pi Chapter, \$2,000, May 2012

Center for Nursing Research (Treadmill Equipment), October 2012 The UTHSC-H, School of Nursing

Global Korean Nursing Foundation (GKNF)-US, \$2,000, August 2013

Dr. Meininger's Professorship Research Support (Assay kits), December 2013 The UTHSC-H, School of Nursing

\section{PUBLICATIONS AND PAPERS}

Park, E., Meininger, J. C., Kang, D., \& Gabriel, K. P. Association of cardiorespiratory fitness and adiposity with inflammatory biomarkers in young adults. In preparation for submission.

Park, E., Meininger, J. C., Baun, M., \& Kang, D. Anthropometric adiposity measures and inflammatory biomarkers in adolescents and young adults: A systematic review. In preparation for submission.

Park, E. \& Meininger, J. C. Effects of exercise interventions on inflammatory markers in healthy adults: A systematic review. In preparation for submission.

Master Thesis: The prevalence of cardiovascular risk factor in type 2 diabetes in an innercity primary care practice, The State University of New York at Buffalo.

\section{PRESENTATIONS}

Park, E., Meininger, J. C., Kang, D., \& Gabriel, K. P. (August 2013). Association of cardiorespiratory fitness and adiposity with inflammatory biomarkers in young adults. Presented at the Sigma Zeta Pi conference, The UTHSC-H, School of Nursing (podium presentation).

Park, E. \& Meininger, J. C. (April 2012). Effects of exercise interventions on inflammatory markers in healthy adults: A systematic review. Presented at the Nursing Research Day, The UTHSC-H, School of Nursing/Sigma Zeta Pi (poster presenter). 
Tukov, M. S., Park, E., \& Rejman, K. P. (April 2010).The prevalence of cardiovascular risk factors in type 2 diabetes in an inner-city primary care practice. Presented at the Sigma Xi Research Day, The State University of New York at Buffalo (poster presenter).

\section{PROFESIONAL MEMBERSHIPS}

Sigma Theta Tau International Society of Nursing, Zeta Pi Chapter, 2011-Present

Sigma Theta Tau International Society of Nursing, Gamma Kappa Chapter, 2007-2011 American College Nurse Practitioner (ACNP), 2010-Present

Southern Nursing Research Society (SNRS), 2012-Present

Council for the Advancement of Nursing Science (CANS), 2012-Present

Preventive Cardiovascular Nursing Association (PCNA), 2011-Present

American Heart Association (AHA), 2012-Present

American College of Sports Medicine (ACSM), 2014-Present

Obesity Society, 2014-Present

\section{COMMUNITY SERVICE}

Volunteer, ST. JOSEPH'S OFFICE, May 1996 - July 2001, Seoul, South Korea -Nonprofit organization

-Provided comprehensive health care and support services to homeless

-Presented nursing care and emotional support for those living on the margins of society or are forsaken by society as a registered nurse volunteer

\section{RESEARCH EXPERIENCE AND TRAINING RELEVANT PROJECTS}

Ph.D. Dissertation, "Association of Cardiorespiratory Fitness and Adiposity with Inflammatory Biomarkers in Young Adults"

-Trained for Biological Laboratory Practicum for Biobehavioral Research, the UTHSC-H, School of Nursing, Biological Laboratory, May 2012-Present -Trained for Sub-Maximal Cardiorespiratory Fitness Testing, the UTHSC-H, Health Recreation Center, Houston, Texas, January 2012-Present

Master Thesis, "The Prevalence of Cardiovascular Risk Factor in Type 2 Diabetes in an Inner-City Primary Care Practice"

-Data Collector, JUDGE METTINA COMMUNITY HEALTH CENTER,

Buffalo, New York, May 2009-December 2009

-Collected data using chart reviews on patients with Type 2 diabetes

-Data coding and entering using SPSS soft program

Nursing Research Day: Moderator in Community Section

April 2013

The UTHSC-H, School of Nursing/ Sigma Zeta Pi 
Cardiometabolic Journal Club

January 2011-June 2013

Chair: Dr. Meininger, Co-chair: Dr. Gallagher

The UTHSC-H, School of Nursing

\section{TEACHING EXPERIENCE}

Teaching Assistant, Department of Acute and Continuing Care, The UTHSC-H, School of Nursing, May 2013-August 2014

Management Patients in High Acuity Settings Adult Health Care I

May 2013-August 2014

May 2013

Teaching Activities

Curriculum Planning and Development

Fall 2013

-Presented and demonstrated "Providing Tracheostomy Care" to peers and faculty 